\title{
Ghana: Poverty Reduction Strategy Paper Annual Progress Report
}

Poverty Reduction Strategy Annual Progress Reports (PRSPs) are prepared by member countries in broad consultation with stakeholders and development partners, including the staffs of the World Bank and the IMF. Updated every three years with annual progress reports, they describe the country's macroeconomic, structural, and social policies in support of growth and poverty reduction, as well as associated external financing needs and major sources of financing. This country document for Ghana, dated March 2005, is being made available on the IMF website by agreement with the member country as a service to users of the IMF website.

To assist the IMF in evaluating the publication policy, reader comments are invited and may be sent by e-mail to publicationpolicy@imf.org.

Copies of this report are available to the public from

International Monetary Fund • Publication Services

$70019^{\text {th }}$ Street, N.W. $\bullet$ Washington, D.C. 20431

Telephone: (202) 623-7430 • Telefax: (202) 623-7201

E-mail: publications@imf.org • Internet: http://www.imf.org

Price: $\$ 15.00$ a copy

\section{International Monetary Fund Washington, D.C.}





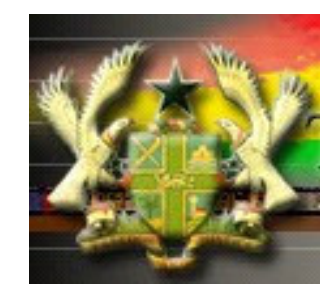

\section{GHANA POVERTY REDUCTION STRATEGY 2004 Annual Progress Report}




\section{ACRONYMS}

\begin{tabular}{|c|c|}
\hline $\mathrm{ADB}$ & African Development Bank \\
\hline ADR & Alternative Dispute Resolution \\
\hline AESD & Agricultural Engineering Services Directorates \\
\hline $\mathrm{AG}$ & Attorney General's Department \\
\hline APR & Annual Progress Report \\
\hline ART & Anti-Retro-viral Therapy \\
\hline AS & Audit Service \\
\hline ABEDA & Arab Bank for Economic Development in Africa \\
\hline BESIP & Basic Education Sector Improvement Programme \\
\hline BoG & Bank of Ghana \\
\hline BPEMS & Budget and Public Expenditure Management \\
\hline CAGD & Controller and Accountant General's Department \\
\hline $\mathrm{CBO}$ & Community Based Organization \\
\hline CEPA & Centre for Policy Analysis \\
\hline CEPS & Customs Excise and Preventive Service \\
\hline CG & Consultant Group \\
\hline CHPS & Community Health Planning and Services \\
\hline CHRAJ & Commission for Human Rights and Administrative Justice \\
\hline CIDA & Canadian International Development Agency \\
\hline CPI & Consumer Price Index \\
\hline CRMAS & Community Resource Management Areas \\
\hline CRT & Criterion Referenced Test \\
\hline CSOs & Civil Society Organisations \\
\hline CSPG & Cross Sectoral Planning Groups for the GPRS update \\
\hline CWIQ & Core Welfare Indicators Questionnaire \\
\hline CWSA & Community Water and Sanitation Agency \\
\hline $\mathrm{DA}$ & District Assemblies \\
\hline DACF & District Assemblies Common Fund \\
\hline DANIDA & Danish Aid Agency \\
\hline DAs & District Assemblies \\
\hline DFID & Department for International Development (UK) \\
\hline DHS & Demographic and Health Survey \\
\hline \multicolumn{2}{|l|}{ DMIS } \\
\hline DMTDP & District Medium Term Development Plan \\
\hline DP & Development Partners \\
\hline DPCU & District Planning Coordinating Unit \\
\hline DPMG & District Poverty Monitoring Group \\
\hline DSW & Department of Social Welfare \\
\hline DWST & District Water and Sanitation Team \\
\hline EFA & Education For All \\
\hline EMIS & Education Management Information System \\
\hline ESP & Education Strategic Plan \\
\hline EPA & Environmental Protection Agency \\
\hline EXIM & Export Import \\
\hline FASDEP & Food and Agriculture Sector Development Program \\
\hline FCUBE & Free Compulsory Universal Basic Education \\
\hline FGD & Focus Group Discussion \\
\hline FOB & Free On Board \\
\hline GACC & Ghana Anti-Corruption Coalition \\
\hline
\end{tabular}




\begin{tabular}{|c|c|}
\hline GBB & Government Book of Business \\
\hline GCB & Ghana Commercial Bank \\
\hline GDHS & Ghana Demographic and Health Survey \\
\hline GDO & Gender Desk Officer \\
\hline GDP & Gross Domestic Product \\
\hline GER & Gross Enrolment Rate \\
\hline GES & Ghana Education Service \\
\hline GET FUND & Ghana Education Trust Fund \\
\hline GHDS & Ghana Health and Demographic Survey \\
\hline GHS & Ghana Health Service \\
\hline GIDA & Ghana Irrigation Development Authority \\
\hline GLSS & Ghana Living Standards Survey \\
\hline GoG & Government of Ghana \\
\hline GPRS & Ghana Poverty Reduction Strategy \\
\hline GSS & Ghana Statistical Service \\
\hline GTZ & German Technical Assistance \\
\hline HIRDP & High Impact Rapid Delivery Programme \\
\hline HIPC & Heavily Indebted Poor Country Initiative \\
\hline HIV & Human Immunodeficiency Virus \\
\hline HMIS & Health Management Information System \\
\hline HRD & Human Resource Development \\
\hline ICCES & Integrated Community Centres for Employable Skills \\
\hline ICT & Information and Communication Technologies \\
\hline IDA & International Development Agency \\
\hline IEA & Institute of Economic Affairs \\
\hline IGR & Internally Generated Revenue \\
\hline ILO & International Labour Organization \\
\hline IMF & International Monetary Fund \\
\hline ISODEC & Integrated Social Development Centre \\
\hline ITTU & Intermediate Technology Transfer Unit \\
\hline KfW & Kreditanstalt fur Wiederaufbau \\
\hline KIA & Kotoka International Airport \\
\hline LAP & Land Administration Project \\
\hline LPG & Liquefied Petroleum Gas \\
\hline LTU & Large Taxpayers Unit \\
\hline $\mathrm{M} \& \mathrm{E}$ & Monitoring and Evaluation \\
\hline MCT & Ministry of Communication and Technology \\
\hline MDAs & Ministry(ies), Department(s) and Agency(ies) \\
\hline MDBS & Multi Donor Budget Support \\
\hline MDGs & Millennium Development Goals \\
\hline MLGRD & Ministry of Local Government and Rural Development \\
\hline MMR & Maternal Mortality Ratio \\
\hline MOES & Ministry of Education and Sports \\
\hline MOFA & Ministry of Food \& Agriculture \\
\hline MOFEP & Ministry of Finance and Economic Planning \\
\hline $\mathrm{MOH}$ & Ministry of Health \\
\hline MOTI & Ministry of Trade and Industry \\
\hline MOWAC & Ministry of Women and Children Affairs \\
\hline MPSD & Ministry of Private Sector Development \\
\hline MRT & Ministry of Roads and Transport \\
\hline NDAP & National Decentralization Action Plan \\
\hline
\end{tabular}




$\begin{array}{ll}\text { NDPC } & \text { National Development Planning Commission } \\ \text { NED } & \text { National Economic Dialogue } \\ \text { NGP } & \text { National Governance Program } \\ \text { NIPMG } & \text { National Intra-Agency Poverty Monitoring Group } \\ \text { NTR } & \text { Non Tax Revenue } \\ \text { OHCS } & \text { Office of the Head of Civil Service } \\ \text { OOP } & \text { Office of the President } \\ \text { OVC } & \text { Orphans and Vulnerable Children } \\ \text { PEM } & \text { Public Expenditure Management } \\ \text { PFM } & \text { Public Financial Management } \\ \text { PLWHA } & \text { People Living With HIV/AIDS } \\ \text { PPB } & \text { Public Procurement Board } \\ \text { PRGF } & \text { Poverty Reduction and Growth Facility } \\ \text { PRSC } & \text { Poverty Reduction Support Credit } \\ \text { PSR } & \text { Public Sector Reform } \\ \text { PSRP } & \text { Public Sector Reform Programme } \\ \text { PPSD } & \text { Private Sector Development } \\ \text { PSI } & \text { Presidential Special Initiative } \\ \text { PSIA } & \text { Poverty and Social Impact Assessment } \\ \text { PUFMARP } & \text { Public Financial Management Reform Program } \\ \text { PURC } & \text { Public Utilities Regulatory Commission } \\ \text { PWDS } & \text { Persons With Disabilities } \\ \text { RCC } & \text { Regional Co-ordinating Council } \\ \text { REDP } & \text { Rural Enterprise Development Program } \\ \text { RPMG } & \text { Regional Poverty Monitoring Group } \\ \text { RPCU } & \text { Regional Planning Co-ordinating Unit } \\ \text { SEA } & \text { Strategic Environmental Assessment } \\ \text { SHEP } & \text { Self Help Electrification Project } \\ \text { SME } & \text { Small Medium Enterprises } \\ \text { STEP } & \text { Skills Training \& Employment Programme } \\ \text { TIN } & \text { Tax Identification Number } \\ \text { TOR } & \text { Terms of Reference } \\ \text { TPD } & \text { Transaction Price Databases } \\ \text { TVET } & \text { Technical \& Vocational Educational Training } \\ \text { UNICEF } & \text { United Nations International Children Educational Fund } \\ \text { VCT } & \text { Voluntary Counselling and Testing } \\ \text { WB } & \text { World Bank } \\ \text { UNDP } & \text { United Nations Development Program } \\ & \end{array}$




\section{TABLE OF CONTENTS}

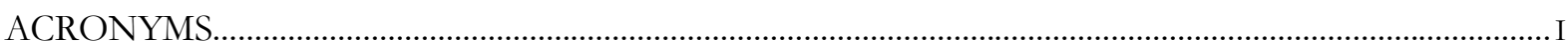

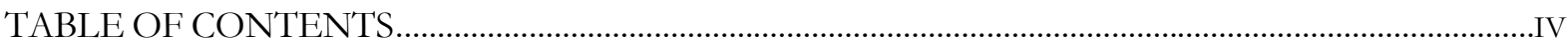

LIST OF TABLES, CHARTS AND FIGURES ………………............................................................ VII

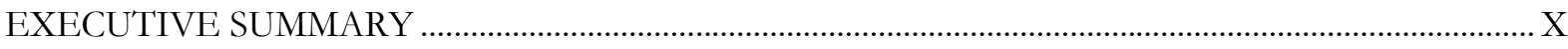

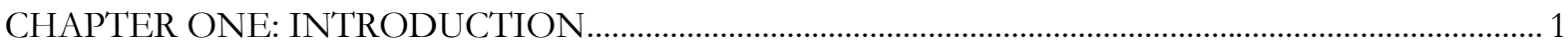

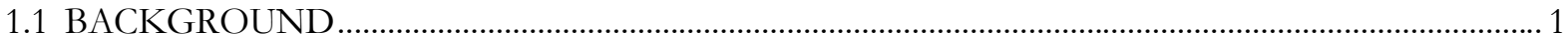

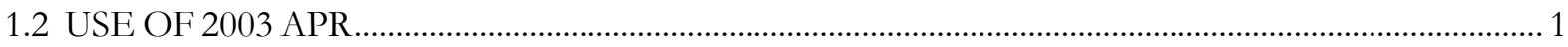

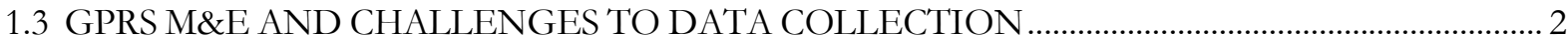

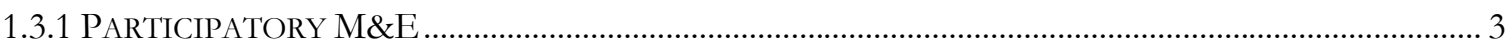

1.3.2 POVERTY SOCIAL IMPACT ASSESSMENTS (PSIAS) …….............................................................. 4

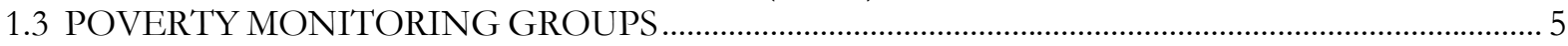

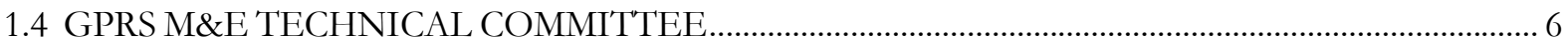

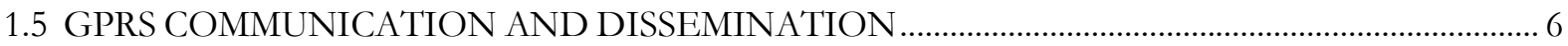

1.6 STRATEGIC ENVIRONMENTAL ASSESSMENT (SEA) ……………………………………....... 7

1.7 RECOMMENDATIONS IN APR 2003 ON GPRS MONITORING

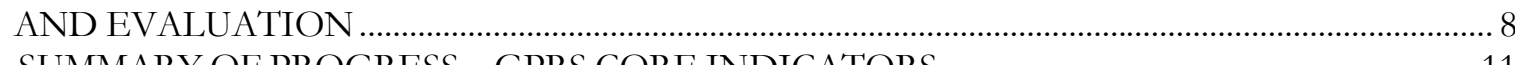

1.8 SUMMARY OF PROGRESS - GPRS CORE INDICATORS ……….............................................. 11

CHAPTER TWO: THE LINKS BETWEEN THE GPRS AND THE 2004 BUDGET .......................... 17

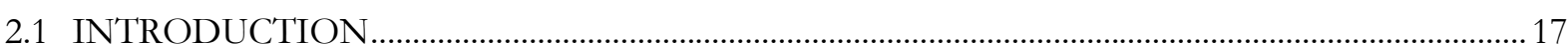

2.2 DISCRETIONARY BUDGET FOR 2004 AND THE MEDIUM TERM PRIORITIES ................. 19

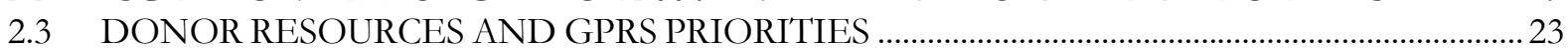

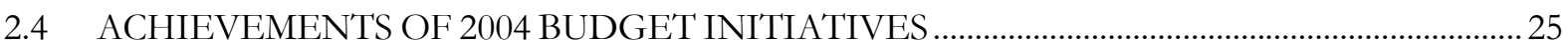

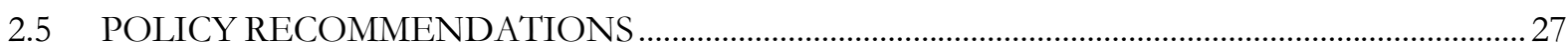

CHAPTER THREE: OVERVIEW OF THE FINANCIAL PERFORMANCE

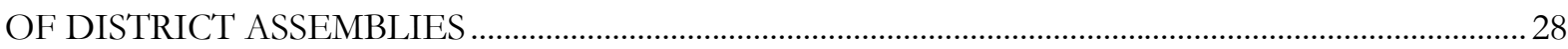

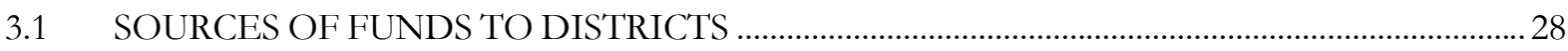

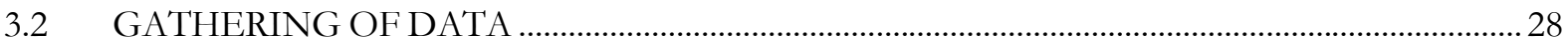

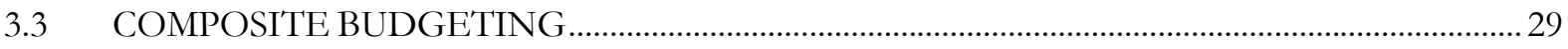

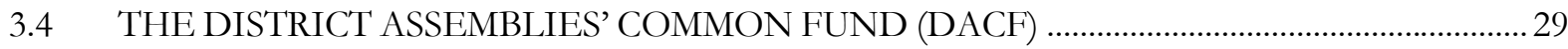

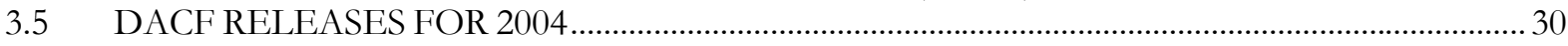

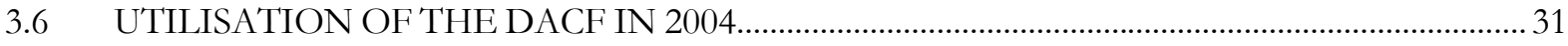

3.7 INTERNALLY GENERATED REVENUE BY DISTRICT ASSEMBLIES ..................................32

3.8 COMPARING NOMINAL GROWTH TO REAL GROWTH IN IGF........................................... 34

3.10 PROBLEMS IN THE MANAGEMENT OF DACF \& INTERNALLY

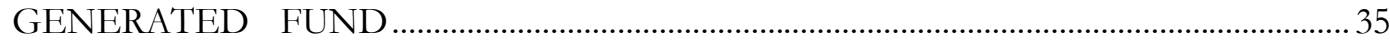

3.11 DISBURSEMENT OF HIPC RELIEF FUNDS IN 2004 ................................................................ 36

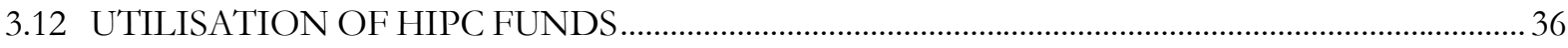

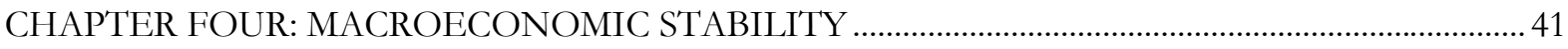

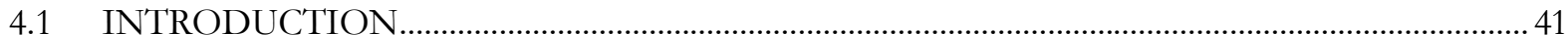

4.2 REVIEW OF THE IMPLEMENTATION OF 2003 APR POLICY RECOMMENDATIONS... 41

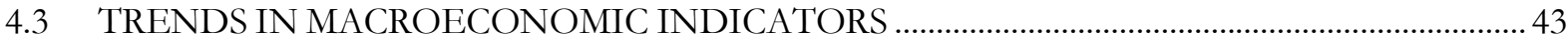

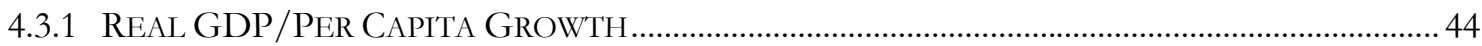

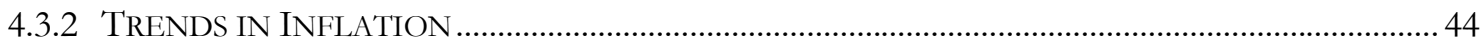




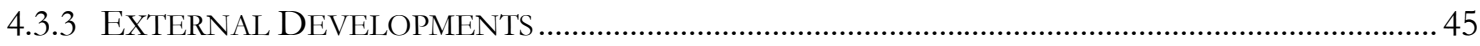

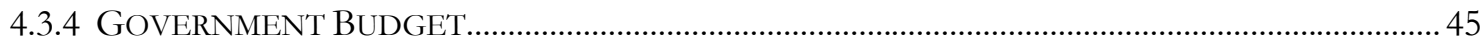

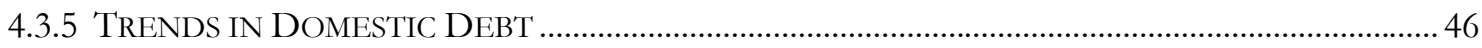

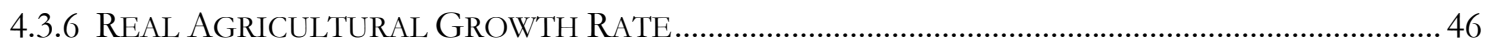

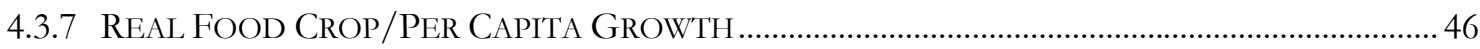

4.4 POVERTY REDUCTION IMPACT OF GROWTH AND GOVERNMENT POVERTY

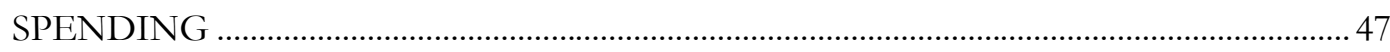

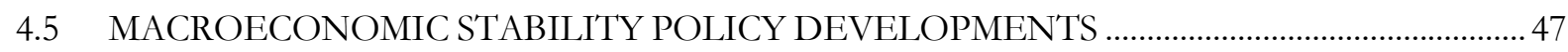

CHAPTER FIVE: PRODUCTION AND GAINFUL EMPLOYMENT ……………………………...... 58

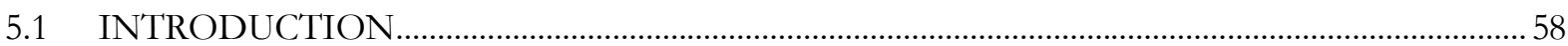

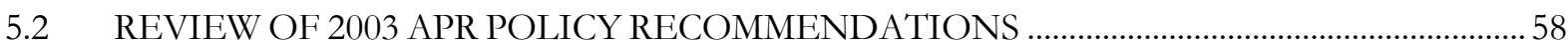

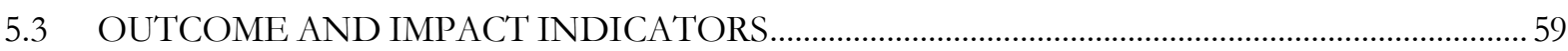

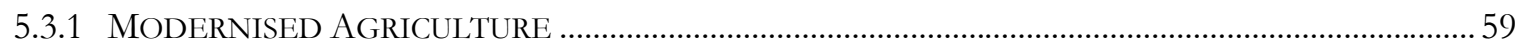

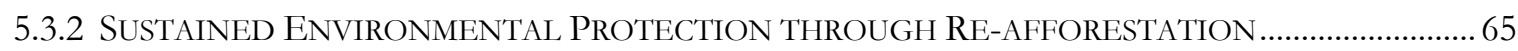

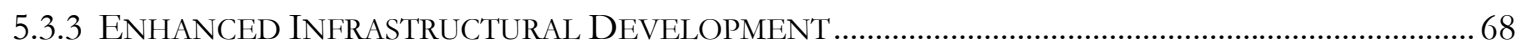

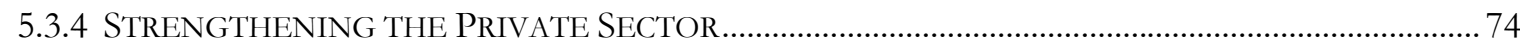

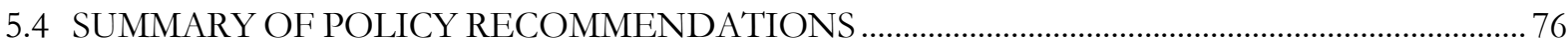

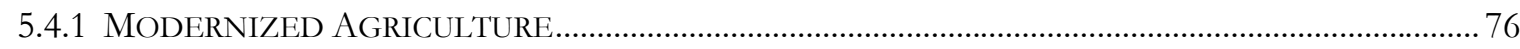

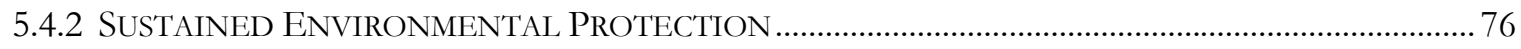

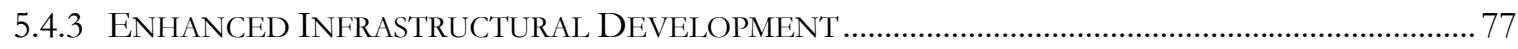

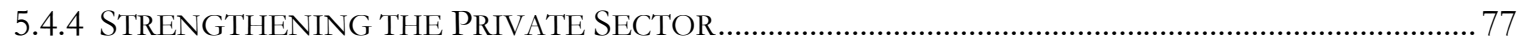

CHAPTER SIX: HUMAN RESOURCE DEVELOPMENT AND BASIC SERVICES ......................... 88

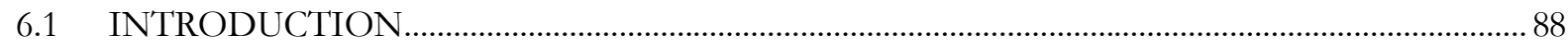

6.2 REVIEW OF 2003 APR POLICY RECOMMENDATIONS …….................................................. 88

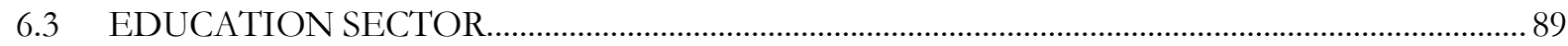

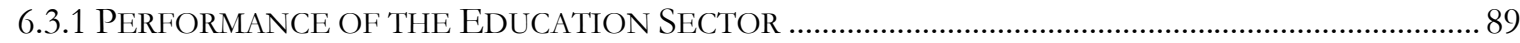

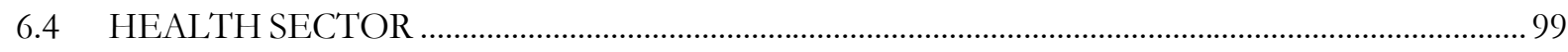

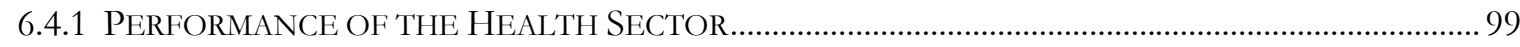

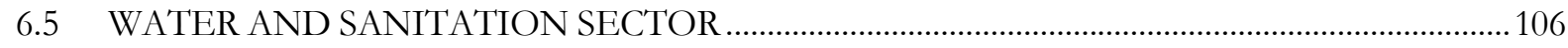

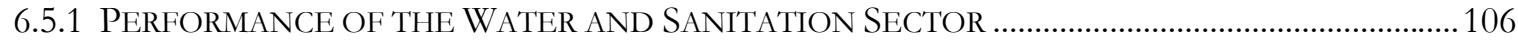

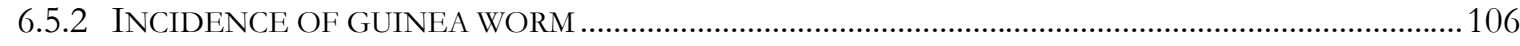

6.6 CITIZENS' ASSESSMENT OF PROVISION OF BASIC SERVICES ...............................................110

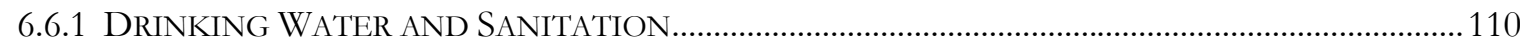

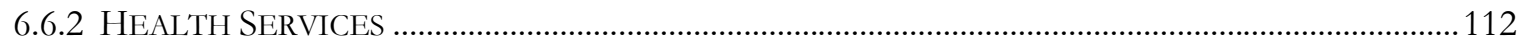

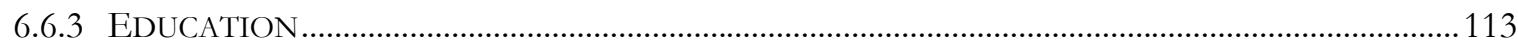

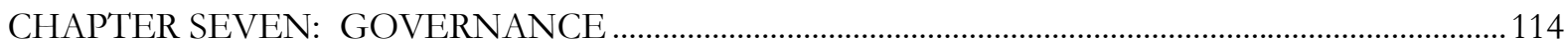

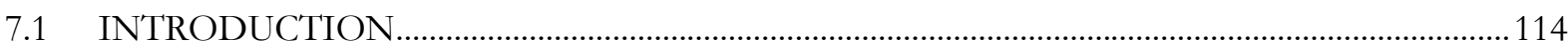

7.2 REVIEW OF 2003 APR POLICY RECOMMENDATIONS............................................................114

7.3 PROGRESS ON POLICY IMPLEMENTATION ON SECURITY AND RULE OF

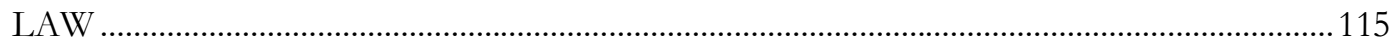

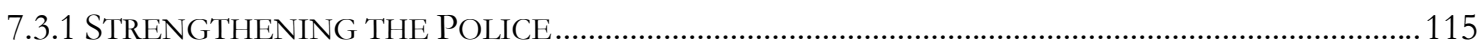

7.3.2 IMPROVING THE ADMINISTRATION OF JUSTICE ………...........................................................119

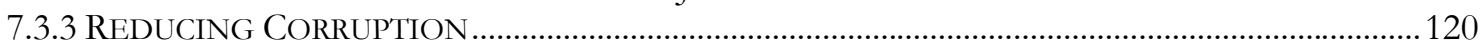

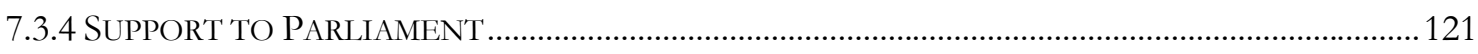

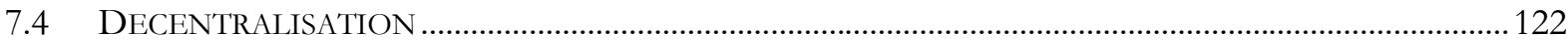

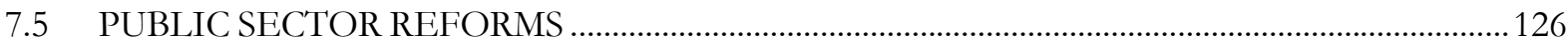

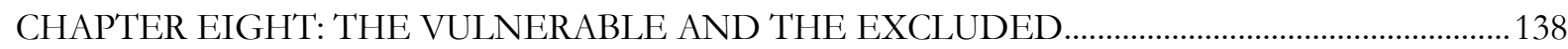




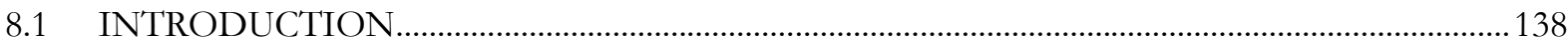

8.2 STATUS OF APR 2003 VULNERABLE AND EXCLUDED POLICY

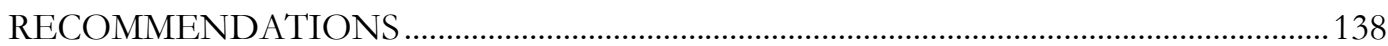

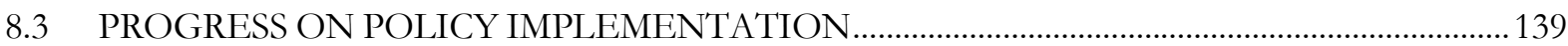

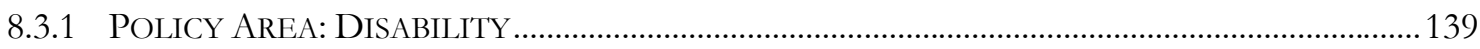

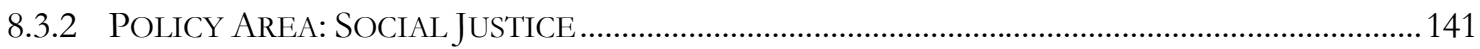

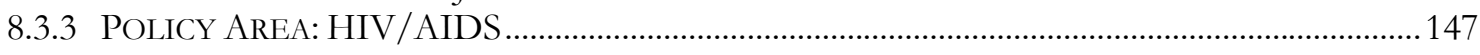

CHAPTER NINE: PROGRESS ON THE MILLENNIUM DEVELOPMENT GOALS.....................152

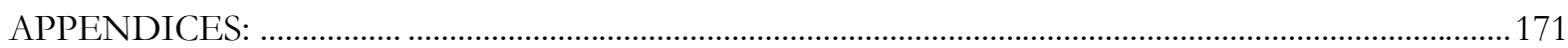

APPENDIX I: COMMENTS/FEEDBACK ON THE GPRS AND APR IN 2004 …...........................171

APPENDIX II: RECORD OF BILLS - FOURTH SESSION—THIRD PARLIAMENT OF THE

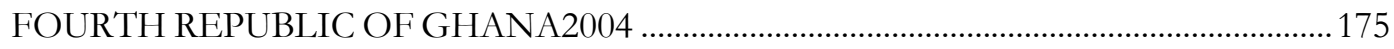




\section{LIST OF TABLES, CHARTS AND FIGURES}

\section{LIST OF TABLES}

TABLE 1.1: RECOMMENDATIONS IN APR 2003 ON GPRS MONITORING AND EVALUATION ……........................... 9

TABLE 1.2: GPRS CORE INDICATORS............................................................................................................... 11

TABLE 2.1: COMPARISON OF GPRS AND 2004 BUDGET MACROECONOMIC FRAMEWORK ....... 18 TABLE 2.2: FUNCTIONAL DISTRIBUTION OF TOTAL DISCRETIONARY

EXPENDITURE: 2001-2004 (\%) 19

TABLE 2.3A: Functional Distribution Of Total GOG EXPENDiture 2001-2004 (\%)........................................ 20

TABLE 2.3B: BUdGETARY AND ACTUAL GOG AND HIPC* SPENDING 2004 ............................................................ 21

TABLE 2.4: EXPENDITURES IN PRIORITY AREAS AS \% OF TOTAL EXPENDITURE.......................................................... 21

TABLE 2.5: GOVERNMENT SPENDING ON POVERTY REDUCTION ………………………………………………….... 22

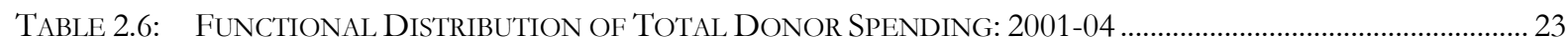

TABLE 2.7: UTILIZATION OF DISCRETIONARY PAYMENTS $\notin$ BILLION……………………………………………………….... 24

TABle 2.8: INVESTMENTS AS A PERCENTAGE OF SECTOR DisCRETIONARY EXPENDITURE IN 2004 ......................... 25

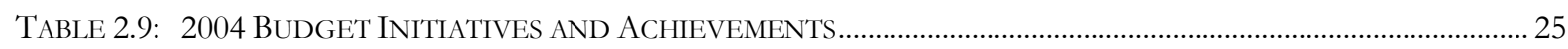

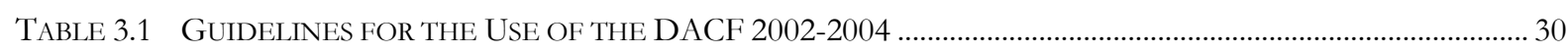

TABLE 3.2: DisbURSEMENTS OF DACF TO DisTRICT ASSEMBLIES IN 2003 \& 2004......................................................... 30

TABLE 3.3: SUMMARY OF UTILIZATION OF DACF DURING 2004 - EXPENDITURE BY SECTOR. 31

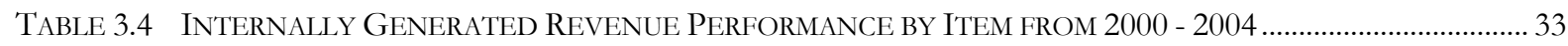

TABle 3.5 Regional Totals of Internally Generated Funds by District AsSEMblies $\quad$ 2000-2004 ...... 33

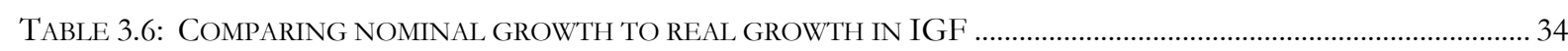

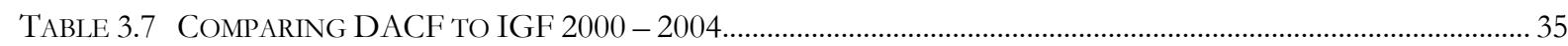

TABLE 3.8: DisburSEMENT OF HIPC FundS IN 2004(AMOUNTS IN CEDIS) ................................................................... 36

TABLE 3.9: HIPC FUNDS TRANSFERRED TO MDAS 2002 - 2004 (AMOUNTS IN CEDIS).................................................... 39

TABLE 4.1: STATUS OF IMPLEMENTATION OF 2003 APR PoLiCy RECOMMENDATIONS ................................................. 41

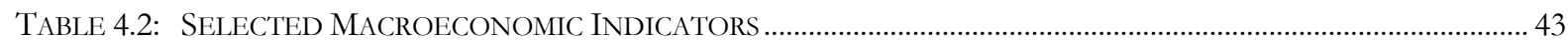

Table 4.3: Percentage Sectoral Growth Rates (2002-2004).............................................................................. 44

TABLE 4.6: POLICY OBJECTIVES OF MTP, PRSC/MDBS ...................................................................................... 54

TABLE 5.1: STATUS OF IMPLEMENTATION OF 2003 APR RECOMMENDATIONS ……………………………………...... 58

TABLE 5.2: SUMMARY OF FOOD SECURITY INDICATORS ACHIEVEMENTS $(2003$ - 2004)................................................. 60

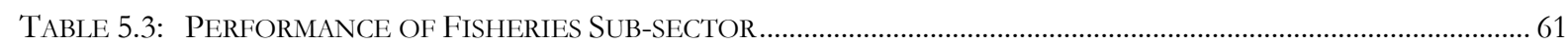

TABLE: 5.4: PROVISION OF IRRIGATION FACILITIES ………………………………………………………………..... 62

TABLE 5.5: MeCHANIZED Agriculture INDiCATOR ACHIEVEMENTS $(2003$ - 2004) .................................................. 63

TABLE 5.6: REFORESTATION INDICATOR ACHIEVEMENTS $(2003$ - 2004) ............................................................................ 65

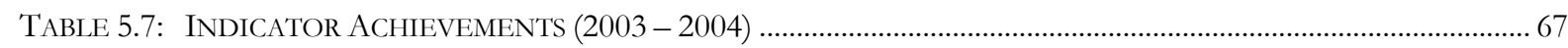

TABLE 5.8: INDICATOR ACHIEVEMENTS $(2003$ - 2004) ……………………………………………………………..... 69

TABLE 5.9: INDICATOR ACHIEVEMENTS $(2003$ - 2004).................................................................................................... 71

TAble 5.10: Physical Completion of Road SECtions under Construction......................................................... 73 
TABLE 5.11: STATUS OF PRIORITY INDICATORS IN PRODUCTION \& GAINFUL EMPLOYMENT ..... 78

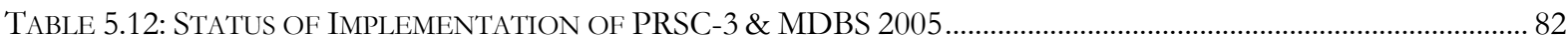

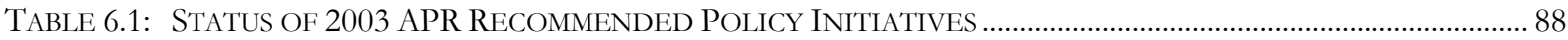

TABLE 6.1: TRENDS IN GROSS PRIMARY SCHOOL ENROLMENT RATIO (GPER), $2001 / 02-2003 / 04$

Table 6.2: Trends in Gross Primary Enrolment Ratio for Girls (GPER) And GENDER Parity IndEX

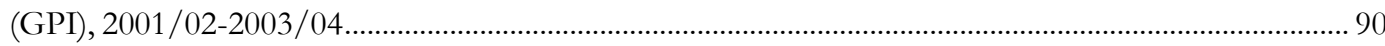

TABLE 6.3: NATIONAL TRENDS IN QUALiTy OF EDUCATION INDICATORS (2001/02-2003/04) 91

TABLE 6.4: TRENDS IN QUALITY OF EDUCATION INDICATORS FOR 40 DEPRIVEDＤISTRICTS (2001/02-2003/04) 91

TABLE 6.5: TREND IN NUMBER OF CLASSROOMS REHABILITATED/CONSTRUCTED, 2003-2004 ..... 92

TABLE 6.6: TREND IN THE PERCENT SHARE OF THE THREE NORTHERN REGIONS IN THE NUMBER OF CLASSROOMS REHABILITATED/CONSTRUCTED, 2002-2004 .92

TABLE 6.7: PTR IN THE NORTHERn REgIONS, 2002/2003 AND 2003/2004 ….........................................................93

TABLe 6.8: Pupil: teXtbook Ratio IN THE 3 Northern Regions, 2002/2003 - 2003/2004_................................. 94

TABLE 6.9: TREND IN NUMBER OF SENIOR SECONDARY SCHOOLS UPGRADED TO

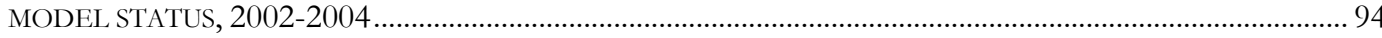

TABLE 6.10: SumMARY OF STATUS OF INDiCATORS IN THE EDUCATION SECTOR, 2004 ............................................ 97

TABLE 6.11A: BASIC HEALTH SECTOR INDICATORS, 1988-2003 (\%) BASED ON GDHS .............................................. 100

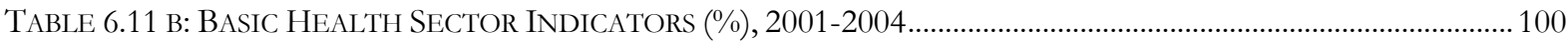

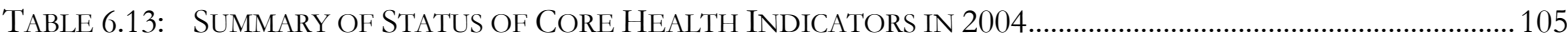

TABLE 6.12: NHIS FUND BY SOURCE, NOVEMBER 2004 …….................................................................................. 103

TABLE 6.14: SUMMARY OF INDICATORS ON ACCESS TO SAFE WATER IN RURAL AREAS ............................................106

TABLE 6.15: TRENDS IN THE REPORTED CASES OF GUINEA WORM ….....................................................................107

TABLE 6.16: INCIDENCE OF GUINEA WORM CASES BY REGION, 2003 AND 2004 _...................................................... 107

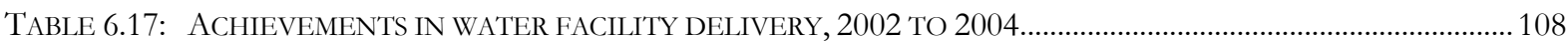

TABLE 6.18: SUMmary OF STATUS OF WATER AND SANITATION INDICATORS IN 2004 ............................................109

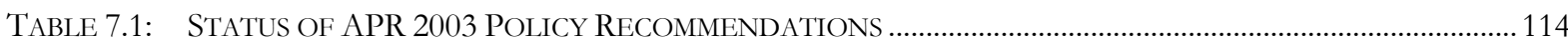

TABLE 7.2: SUMMARY OF PROGRESS ON INDICATORS ON THE SECURITY AND

THE RULE OF LAW ......................................................................................................

TABLE 7.3 COMPARISON OF SUMMARY OF OFFENCES COMMITTED IN 2003 AND 2004 ..........................................116

TABle 7.4 Gender Ratio of THe GHana Police SERVICE AS AT DECEMBER 2004............................................... 117

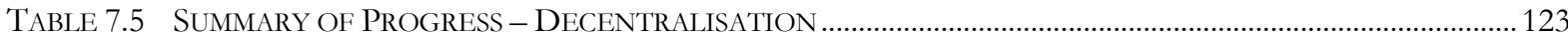

TABLE 7.6: SumMARY OF PROGRESS - PUBLIC SECTOR REFORMS.............................................................................. 126

TABLE 7.7: SUMMARY OF PROGRESS - MONITORING AND EVALUATION ........................................................................ 128

TABLE 7.8: SUMMARY OF PRIORITY INDICATORS - GOVERNANCE...............................................................................129

TABLE 8.1: STATUS OF APR 2003 VULNERABLE AND EXCLUDED POLICY

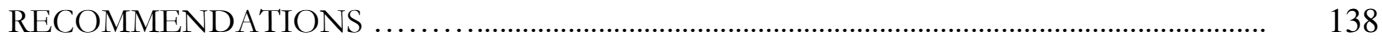

TABLE 8.2: THE NUMBER OF CAPACITY BUILDING PROGRAMMES ORGANIZED PER REGION....................................140

TABLE 8.3: COMPARATIVE WELFARE SERVICES PROVIDED TO THE 
TABLE 8.4: STATISTICS OF CASES REPORTED TO WOMEN AND JUVENILE

UNIT (WAJU) GHANA POLICE SERVICE FROM JANUARY 1999

TO DECEMBER 2004

TABLE 8.4: SUMMARY OF STATUS OF PRIORITY INDICATORS FOR VULNERABLE AND

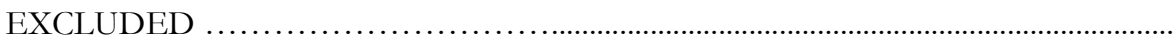

Table 9.1: Status at a Glance, 2004 - Ghana's Progress towards the Millennium Development

GOALS 152

\section{LIST OF CHART}

CHART 3.1: A PROPORTIONAL DISTRIBUTION OF DACF UTILISATION BY SECTOR ....................................................... 32

CHART 3.2: PERCENTAgE CONTRIBUTION TO IGF BY ITEM: 2004.

\section{LIST OF FIGURES}

FIGURE 3.2: INTERNALLY GENERATED REVENUE BY DISTRICT ASSEMBLIES 2000 - 2004.......................................... 34

FIGURE 3.1: REAL GROWTH (\%) IN INTERNALLY GENERATED REVENUE .............................................................. 34

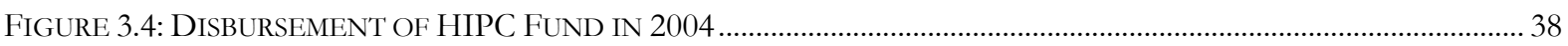

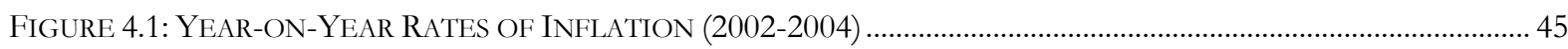

FIGURE 7.1: GENDER DiSTRIBUTION OF RECRUITS CURRENTLY IN TRAINING..................................................... 118 


\section{EXECUTIVE SUMMARY}

\section{INTRODUCTION}

This is the third Annual Progress Report on the implementation of the Ghana Poverty Reduction Strategy (GPRS) in 2004. The report uses a set of indicators, triggers and targets, for monitoring and evaluating the achievements and impacts of the key policy and programme interventions undertaken in the five thematic areas by the government. Policy recommendations are also made to address key weaknesses that have been identified in the implementation of the GPRS; which are important inputs to the production of the new development policy framework for the country.

Over the recent years there has been increasing demand for the results of monitoring and evaluation of the GPRS, especially by Ministry of Finance \& Economic Planning MoFEP and the Development Partners. The demand from other stakeholders however, has been much lower due to the limited awareness about the contents and process of preparation thus a more extensive and intensive dissemination process has been recommended. Additionally, to enhance the ownership and commitment of the key stakeholders in government to the M\&E process it is recommended that the annual performance contracts, negotiated between the Chief Directors with the Head of Civil Service should include the support for the M\&E of the GPRS.

Many of the challenges to data collection identified in the 2003 APR still persist. These include: lack of feedback and incentives to motivate staff in the MDAs, Regions and Districts to institutionalise $\mathrm{M} \& \mathrm{E}$ activities; inconsistencies in data between the regions and districts; challenges of addressing the different M\&E needs of different stakeholders; inadequate resources for $M \& E$ at all levels. Although the $M \& E$ process is deepening additional resources, attention is required for the national, regional and district level M\&E to address key shortcomings of the process. Development Partners (DPs) are also encouraged to harmonize their M\&E requirements and to ease the burden on Ministries, Departments and Agency (MDAs) \& District Assemblies (DAs), as they can use the GPRS M\&E process as the major point of reference.

The GPRS M\&E Technical Committee proposed in the M\&E Plan has not been established yet. Greater coordination and harmonisation is needed for $\mathrm{M} \& \mathrm{E}$ activities between the core organisations at the central level (MOFEP, NDPC, OOP, MLGRD, GSS, and OHCS), with a focus on better information flows and incentives to improve GPRS monitoring and evaluation.

The National Interagency Monitoring Groups (NIPMGs) which bring together stakeholders from MDAs, DPs and CSOs at national level, were actively involved in the preparation of the APRs. Regional Poverty Monitoring Groups (RPMGs) were inaugurated in eight (8) regions in 2004. However, to fulfil their mandate, guidance from national level as well as additional technical and financial resources are required to ensure the RPMGs are effective and sustainable.

In 2004 the implementation of the GPRS communication strategy developed in 2003 was initiated with the following objective "To create a national understanding of the goals, objectives and strategies of the GPRS, and to ensure commitment to, and effective participation of communities, groups and individuals in the implementation of the GPRS".

Experience during the preparation of previous annual progress reports, has demonstrated a challenge in enabling the citizenry to fully participate in the M\&E process. Thus a participatory $M \& E$ exercise was undertaken by the NDPC, at the end of the 3rd quarter of 2004. The primary objective of the survey was to obtain feedback from local citizens about the extent to which the 
GPRS objective of enhancing access to basic services was being achieved at the community level, and to assess citizens' experience of gains in the macroeconomic sector vis-à-vis their living conditions. Results of the survey have been used in various thematic areas of the APR.

The APR also used the results of the five PSIAs to improve understanding of the potential linkages between policies and poverty impact, the need for pro poor targeting, and the importance of identifying specific poor groups, their needs, opportunities, risks, strengths and weaknesses. The gender dimension could have been stronger as this is generally an area where more information and more analysis of measures, is needed. However, dissemination of the results of the PSIA's beyond the PSIA Technical Committees is in most cases yet to take place.

Ghana is one of the first countries to make use of a Strategic Environment Assessment as a vehicle for reviewing and refining the Poverty Reduction Strategy. The SEA Report was finalized and approved in 2004. Specific recommendations are given for each of the thematic areas of the GPRS with suggestions on rural environment (primary source of more than $50 \%$ of GDP), natural resource conservation, sustainable development, disaster prevention, "green" taxes and accounting, measures to protect the poor and the environment, root causes of lack of gender equity (include women's access to land), environmental health and water, private sector, etc.

\section{LINK BETWEEN THE BUDGET AND THE GPRS}

The macroeconomic issues proposed by the 2004 budget are similar to those of the GPRS with only a few exceptions. Both the budget and the GPRS propose to tackle issues which include: reduction in the domestic debt; reduction of inflation to single digits; increasing revenue mobilization; curtailing deficit financing by pursuing a policy of zero net domestic financing; rationalization of expenditure through effective monitoring.

Workshops were organised to improve MDAs understanding of the MTEP process as well as linking the GPRS and APR to the Budget; MDAs were required to show the progress made in achieving targets set in the GPRS and the remaining gaps up to 2005 and incorporate poverty reduction policies of the GPRS into their Strategic Plans.

Budget allocations to the Social Service sector have increased consistently since the beginning of the implementation of the GPRS. The 2004 spending reported by CAGD indicates that GoG spending in the Social Sector of $55.1 \%$ of MDAs discretionary spending exceeded the budget target of $48.1 \%$. This consistent increase of resources to the Social Services sector translates into an increase in resources to activities directed to the poor, vulnerable and excluded reflecting the broad priorities of the GPRS. Within the sector there was a switch in resources to the Health sub-sector at the expense of education. Allocation to education in 2004 was slightly below that of 2003. Economic Services sector's allocation has declined since 2002 declining by almost 50 percent from $18.02 \%$ to $8.9 \%$ which is below the GPRS target of $10.3 \%$. Allocations to the agriculture sub-sector continue to decline. From 7.1\% in 2001, it has declined to 3.03\% in 2004 . Infrastructure's share has been below the GPRS targets. The allocation of $10.93 \%$ in 2004 was below the GPRS targets of 19.1\%. The Public Safety sector has been receiving increased allocation reflecting the importance of upholding the rule of law, public order and safety as major pillars of the GPRS with a slight increase in 2004 to $11.9 \%$ from the 2003 allocation of $11.52 \%$.

Government Poverty Reduction Spending: The 2004 Budget had a strong linkage with the GPRS and could therefore be described as pro-poor budget. Increased pro-poor spending was made by 
government. In spite of the financial difficulties facing the government, poverty related activities were funded in full. This poverty spending constituted about $28.1 \%$ of total government spending in 2004 and slightly exceeded the planned expenditures of $27.97 \%$ for the year.

Donor resources to sectors of the economy were in broad conformity with the Medium Term Priorities of the GPRS. There was a significant increase in allocation to Administration higher than in 2002 and 2003 reversing the downward trend since 2001. The Ministry of Finance also experienced a little increase. But it was the Ministry of Health which was a significant beneficiary of donor expenditure, improving on the increase from $8.0 \%$ in 2002 to $9.9 \%$ in 2003 to $15.44 \%$ in 2004. Infrastructure which is the largest recipient of donor allocations experienced a decline from $51.5 \%$ to $43.49 \%$. An important aspect of donor funding was the unexpected increase in actual expenditure to $₫ 5.8$ trillion which is more than double the budget target for 2004 of $\notin 2.492$ trillion

\section{FINANCIAL PERFORMANCE OF THE DISTRICT ASSEMBLIES}

The disbursement of the District Assemblies' Common Fund (DACF) which was characterised by delays in the past has improved and is now timely. The arrears accumulated in previous years are also being cleared. Total disbursements by the Administrator to districts amounted to $ф 857,172,000,000$ in 2004.

In 2004 total Internally Generated Funds (IGF) for all DAs amounted to $£ 225,819,115,201$ compared to $\notin 188,775,332,515$ in 2003 . Analysis of internal revenue generation of the District Assemblies shows mixed results. Many Districts are in several months arrears in their submissions of monthly Trial Balances to the MLGRD. With the review and issuance of a new Financial Memoranda to replace the old Act 59, the MLGRD should insist on compliance with rules governing financial management in the DAs

Total HIPC disbursements for 2004 was $\not 1,816,861,751,626$ representing an increase of $116 \%$ over the 2003 figure. A total amount of $\phi 294,727,354,384$ representing about $16.22 \%$ of total disbursement went to the District Assemblies/MLGRD in the year under review. There is however the need for some improvement in the process of allocation and disbursement of the HIPC Fund by the Ministry of Finance. It should be guided by a budget or a transparent allocation formula.

\section{INCIDENCE OF POVERTY IN GHANA}

Though data for examining the outcome of increased government spending on poverty reduction programmes and effects of growth and macro-stability is not widely available, the implementation of the GPRS appears to be putting a downward pressure on poverty growth especially for the poor and the extreme poor ${ }^{1}$.

Using household assets ownership data from the two CWIQ surveys, asset poverty indices have been calculated to describe the trends in poverty between 1997 and 20032. The pattern remains roughly the same for the periods. Poverty is higher in rural than urban areas while the coastal belt remains relatively better off than the savanna; urban employees in regular employment are relatively better off than their rural counterparts; workers in agriculture are poorer than those in

\footnotetext{
${ }^{1}$ Data used for the analysis here are derived from the CWIQ Survey Reports of 1997 and 2003 and a 2004

Citizens Report Card Survey undertaken by NDPC.

${ }^{2}$ World Bank Staff "Determinants of, and trends in, asset poverty in Ghana using QWIQ datasets", 2005.
} 
other sectors. Poverty levels have declined by $7 \%$ from $42 \%$ in 1997 to $35 \%$ in 2003. Further decline is assumed for 2004 on account of the above-target growth in the Gross Domestic Product which is driven primarily by increased output in agricultural production.

The breakdown of the 7\% poverty decline in Ghana between 1997 and 2003, using asset measure indicates that the reduction of the incidence of poverty for the country as a whole reflects in a large measure, the effect of the growth with the impact of the redistribution effect. About $87 \%$ of the decline in poverty is due to economic growth with income redistribution accounting for the remaining 13 percent. This indicates strongly that the poorest among the poor have benefited less from growth i.e. they have experienced lower increases in their incomes than the population at large.

\section{MACROECONOMIC STABILITY}

The macroeconomic indicators show that targets set by government have been achieved and this has led to a stable economic environment, with reduced inflation, lower interest rates, a relatively stable currency, and a strong external reserves position. This has been achieved partly through improved fiscal management, prudent monetary management and economic growth.

The GDP growth rate of 5.8\% in 2004 exceeded the budget projection of $5.2 \%$, and was also better than the target of $5.0 \%$ in the GPRS for the medium term. The basis of this high growth rate was the outstanding performance of $7.5 \%$ by the agricultural sector fuelled by a $29.9 \%$ surge in cocoa production.

By the end of 2004 inflation rate was $11.8 \%$ with the food component decreasing from $21.5 \%$ in December 2003 to $15.5 \%$ by December 2004. The fall in the rate of inflation has been attributed to a combination of factors, including: improved food supply; monetary restraint; a relatively stable exchange rate in an environment of diminishing inflationary expectations; and improved fiscal performance in the face of election year and donor inflows.

The cedi depreciated by only $2.2 \%$ against the dollar but experienced higher depreciation against the pound and the euro at 12.1 per cent and 10.7 per cent respectively. As a percentage of GDP domestic revenue has showed a smooth and steady growth since 2002 , from $20.7 \%$ to $23.8 \%$ of GDP in 2004. The growth of domestic revenue has exceeded the rate of inflation, meaning improved real revenue generation. The overall budget deficit was equal to $3.2 \%$ of GDP exceeding the target of $1.7 \%$, but below the 2003 deficit of $3.4 \%$.

The domestic debt/GDP ratio reduced from $26.8 \%$ in 2001 to $22.6 \%$ in 2003 . This ratio further declined in 2004 to $17.6 \%$. The reduction in domestic debt has brought some relief to the private sector with an increase in credit to the sector

\section{Policy Actions}

The macroeconomic stability achieved in 2004 resulted from several measures pursued by the government which included the reduction and restructuring of domestic debt, improvement in public expenditure management, improvement in fiscal resource mobilization, the pursuance of price and exchange rate stability, and the creation of a more diversified financial sector.

Reducing and Restructuring The Domestic Debt. Several activities were undertaken by government to reduce and re-structure domestic debt including paying down domestic debt and developing 
medium and long-term instruments: $₫ 301.4$ billion constituting 16.4\% of HIPC funds was used to repay domestic debt; With regard to restructuring the domestic debt, the Government issued Medium Term Bonds: 2-3 year Floating Rate Notes with the interest rates tied to Treasury Bill interest rates and 2-3 Year Fixed Rate Notes.

Improvement in Public Expenditure Management (PEM): As part of the process of modernising the PEM Regulatory Framework, the Financial Administration Regulations, 2004, LI 1802 for the Financial Administration Act, 2003 was passed by Parliament in August 2004. Following the passage of the three Public Financial Management laws, the MOFEP conducted a nationwide educational and awareness programme to operationalise the laws. To strengthen budget formulation summary expenditure reports were prepared on the basis of both the conventional and Government Financial Statistics (GFS) format and circulated to all line Ministries on a timely basis. PUFMARP continued to make significant progress in the implementation of the various components in the Ministry of Finance and Economic Planning and Controller and AccountantGeneral's Department. BPEMS was set up at five MDAs where hands on training were provided. The public procurement and the Internal Audit Agency Boards were inaugurated in August 2004. To further improve upon the decision making process in the area of domestic debt management, a Domestic Debt Management Unit was created in the MOFEP with the responsibility for forecasting Cash and Public Sector Borrowing Requirement (PSBR), among others functions. An enhanced cash management system was put in place for monthly cash releases.

Improvement in Fiscal Resource Mobilization: A Dividend Policy to guide State Owned Enterprises and Joint Venture companies in the declaration of dividends was introduced. An amount of ф11.5 billion was released to $18 \mathrm{MDAs}$ to implement revenue enhancement measures and an exercise was initiated with the Security Agencies to track illegal operators (in $10 \mathrm{MDAs}$ ) suspected of involvement in the forgery and duplication of Value Books to curtail revenue leakages.

Pursuance of Price and Exchange Rate Stability: The Monetary Policy Committee of the Bank of Ghana which was established in 2003 continued to use monetary policy instruments, particularly the prime rate, to influence inflationary expectation. Policies which improved foreign exchange liquidity, policies of fiscal discipline and prudent monetary programme accounted for the stability of the cedi against the dollar and other major currencies.

Creation of a more Diversified Financial Sector: Implementation of FINSSP, including improving the administrative framework for micro finance was initiated. The Central Settlement and Depository System (CSDS) which is a trading platform for financial instruments, was made operational initially for government securities to further enhance confidence in traders and to facilitate and modernise security trading. The Venture Capital Fund Bill was passed and the Long term Savings law for private pension and housing schemes was enacted. To strengthen the financial market infrastructure and to enhance transparency, Government separated Open Market Operations (OMO) of Bank of Ghana from Public Sector Borrowing Requirement (PSBR). Continuous capacity development and training programmes in Microfinance were organised for ARB APEX Bank and related institutions.

\section{PRODUCTION AND GAINFUL EMPLOYMENT}

The production and gainful employment thematic area focuses on the Modernisation of Agriculture for Rural Development; Environmental Protection through Re-aforestation; Enhanced Infrastructure Development; and Strengthening Private Sector Development. Of 
these four programme areas, the most progress was made in the area of infrastructure development whilst the least was made in environmental protection through re-aforestation.

The assessment of the area of modernising agriculture in Ghana produced mixed results. There was good progress made in the policy objective of ensuring food security as evidenced by an appreciable decrease in post harvest losses for cereals and perishables. Significant activities were undertaken to improve irrigation facilities including an increase of dugouts from 713 in 2003 to about 999 out of the 1309 water facilities in 2004. Several key initiatives were also undertaken to improve the operational and cropping efficiency on existing irrigation projects as well as irrigable land. Furthermore, the objective of agriculture mechanisation recorded modest gains as farmer access to mechanized tillage increased from $8 \%$ in 2003 to $12 \%$ in 2004 showing progress toward the achievement of the target of 15\%. Marked improvements were also recorded in the areas of access to processing equipment and the number of farmers with access to tractors. One area of concern was the fact that the area under cultivation decreased and in some cases caused output to decrease. It is therefore recommended that increased efficiency of extension services be made a key concern of policy. In other words it is not enough to only increase the extension officer to farmer ratio. The extension services should be made more effective.

Under the area of increasing environmental protection, it is found that only two of the eleven indicators which form the basis of assessment, showed good progress. For instance, the hectares of degraded forest reserves planted increased between 2003 and 2004. Also the rate of deforestation slowed down over the review period. However, in terms of indicators such as the number of permanent employment generated of urban areas planted little progress was achieved, The lack of progress is even more pronounced for the indicators that capture improvements in land administration. Implementing agencies cite lack of resources as the major constraint. It is therefore recommended that institutions that are directly involved in the implementation of policies under this area be resourced and equipped to get policies under this area back on track.

The assessment of the area on enhanced infrastructure development was based on a total of eleven indicators for ICT, Energy, and Road Transport. All the indicators showed good progress with some of them exceeding the targets set. It is recommended that this momentum be maintained to ensure that this key enabler of development plays its role effectively. The evidence shows that significant progress was recorded in the provision of telephone access outside the urban centres. The number of fixed telephone lines installed increased from 283,000 in 2003 to 315,682 in 2004 showing steady progress toward the target of 400,000 by 2005 . The number of cellular and pay phones also increased significantly.

The number of schools provided with ICT increased from the 2003 level of 257 to 360 in 2004, signalling good progress toward the target of 514 2005. Additionally, community centres provided with ICT increased from 12 in 2003 to 52 in 2004. In the Energy sector, the evidence shows an increase in the proportion of households with electricity and a steady progress toward the phasing out of the petroleum subsidies.

The Road sector showed significant gains in 2004 as evidenced by several of the indicators. For example, the road condition mix improved from $29 \%$ in good condition, $29.8 \%$ fair, and $40.8 \%$ poor in 2003 to 36\% in good condition, 26\% fair, and 38\% poor for 2004. By 2004 the length of engineered feeder roads had increased to $23,000 \mathrm{~km}$ from its 2001 level of $12,700 \mathrm{~km}$. The evidence also shows completions of significant portions of major highway construction activities such as the Accra/Yamoransa road, Accra/Aflao road, and the Accra/Kumasi road. Maintenance and rehabilitation of feeder roads were undertaken on a large scale. 
Finally, the assessment of the area of strengthening Private Sector Development suggest that generally some progress has been made in all the areas including trade facilitation, improving business environment, manpower development and gender issues. The basis of this assessment is the policy measures undertaken in the course of the year and not on prescribed benchmarks. Therefore a key concern raised is the fact that none of the policy objectives have benchmarks and in some cases, they do not have any indicators. It is therefore suggested that MDAs address this problem as a matter of urgency to enable effective monitoring and evaluation to be undertaken.

\section{HUMAN RESOURCES AND BASIC SERVICES}

The Human Resource and Provision of Basic Services thematic area of the GPRS in the medium term has focused on the expanding and improving efficiency in the delivery of basic services, while addressing issues of geographical and gender equity in access to these services. The achievements as well as the status of policy interventions implemented in 2004 in these sectors are discussed below

\section{Education}

The significant progress registered with access to basic education indicators in 2003 APR continued in 2004. The national primary gross enrolment ratio and those of the deprived regions have all been steadily improving. The national GPER increased from 85.7\% in 2002/2003 to $86.3 \%$ in 2003/2004. Northern and Upper West regions in particular have already exceeded their 2005 targets. However, enrolments rates at the National level and in the Upper East region need to be increased by $2.2 \%$ and $1.9 \%$ respectively to be able to achieve their 2005 targets. Measures toward bridging the gender gap in school enrolment are also yielding positive results but the pace at which the gap is closing has been quite slow.

Progress in improving education quality has been more difficult to measure. The Ministry of Education and Sports is in the process of introducing a National Minimum Standards as a means of assessing student and sector performance. In the interim, input indicators, such as PTRs and textbook ratios have been used to provide proxy measures of quality. At the basic level, the introduction of the new textbook development and distribution policy has led to delays in distribution resulting in a fall in pupil-core text-book ratio, with the deprived districts hardest hit. Pupil teacher ratio PTR at the primary level has increased from 31.3:1 in 2002/203 to 34.0:1 in $2003 / 2004$ academic year, exceeding targeted ratio of 32.7:1. However, wide variations in the ratio exist at the school and district level. The percentage of trained teachers at the primary level has improved marginally, with the 40 deprived districts having the lowest levels.

\section{Policy Actions}

The sector continues to be confronted with a number of policy issues/gaps that remain to be addressed. These include insufficient progress in primary school enrolments; persistent geographical and gender disparities in access to quality education; less than satisfactory quality education and the need to strengthen the efficiency of education service delivery. In response to these issues a range of policy measures were implemented in 2004 to address these problems through the development of the necessary human resources and related social and physical infrastructure.

Enhancing Access to Education: Specific policy measures implemented in 2004 to enhance access to education included the rehabilitation and construction of basic school classrooms; 
implementation of teacher retention schemes; elimination of all approved district levies and introduction of capitation grants in public primary schools in deprived districts; ensuring the timely delivery of core textbooks for primary schools, particularly in most deprived regions; development of one model senior secondary school with libraries and science laboratories in each of the 110 districts in Ghana.

Rehabilitate/construct classrooms: Two hundred and sixteen (216) out of the four hundred and forty (440) 6-unit classroom blocks under construction were completed in 2004 at the cost of 103 billion cedis.

Expand Teacher Retention Scheme: To improve the supply of teachers to remote areas, the following activities were undertaken in 2004: To improve equity in the distribution of teachers, particularly to remote areas, the Ministry of Education and Sports continued to pursue a policy of providing incentive packages to teachers in remote areas. These included the provision of consumer items and accommodation. An amount of 20 billion cedis was spent on the construction of teachers' residences; The District Assemblies Sponsorship Scheme for Teacher Trainees produced 3,812 trained to teachers to work in remote areas; The National Service Secretariat supplemented the supply of teachers to schools in rural areas with 6,981 teachers through its normal posting of service personnel. In addition 52 teachers were posted to remote rural areas under the National Volunteer Service Programme; As a result of these activities the National PTR for primary schools increased. However, the supply of teachers was not enough to improve the PTR in the Northern and Upper East regions. This situation is attributed to the higher overall enrolment during the year under review, without a corresponding increase in teacher supply.

Elimination of all approved district levies and introduction of capitation grants in public primary schools in deprived districts: School levies were abolished and capitation grants were introduced in 40 deprived districts during the year under review. The grant provides all schools in these districts with a decentralised operating budget based on the number of students attending, with higher grant awarded for female students. So far the GES has provided a total of $\phi 13,746,974,999$ for the first and second terms of 2004/2005 academic year to the 40 deprived districts.

Ensure timely delivery of core textbooks in most deprived districts: Pupil/core textbook ratios worsened between 2003 and 2004, particularly in the three deprived northern regions as no new books were procured and distributed. Although an amount of sixteen billion cedis was transferred in 2004 to the Ministry of Education and Sports for the provision of textbook, no disbursements have yet been made due to a delay in the implementation of a new textbook development and distribution policy. The policy demands strict adherence to the new procurement law which requires the Ministry to outsource the procurement of textbooks to the private sector.

Develop/upgrade one SSS to model status in each district: The policy to upgrade one Senior Secondary School into model schools reached the second phase in 2004. Work on the first batch of schools is near completion; preliminary studies to determine the scope of works under the second phase of upgrading 25 schools into model schools were completed in 2004

Reduce gender disparities in education: In 2004 ¿4.4 billion was disbursed to 40 deprived districts to provide scholarships for pupils, out of which $60 \%$ went to girls. Capitation grant of $₫ 35,000$ per female pupils was paid to all public primary schools in 40 deprived districts during the first term of the 2004/2005 academic year.

Improve vocational and technical training: As part of measures to develop and improve Technical and Vocational Education and Training (TVET) work on a national policy on TVET was completed 
in 2004. The national TVET policy will guide the development of strategies to enhance technical and vocational skills for an accelerated national development. Twenty new vocational and technical resource centers were established under GES in the 10 regions located mostly in the rural areas.

Support and enbance training for employable skills: An amount of 6 billion cedis micro credit facility was released to the Ministry of Manpower Employment and Youth for disbursement to graduates of the STEP Programme to enable them establish their own small-scale enterprises. Under Phase 2 of the Skills Training and Employment Programme (STEP), about twelve thousand seven hundred and fifty $(12,750)$ people were trained in various trade areas including food processing, dressmaking, hairdressing, masonry, and carpentry. About 7,000 out of the 12,750 were trained and set up in agricultural vocations such as snail farming, grass-cutter rearing, bee-keeping and mushroom farming

Improve efficiency and equity of financing education with attention to greater poverty impact: Measures implemented in 2004 to improve efficiency and equity in financing education included the delivery of increased resources to 40 deprived districts; and increase in the execution rate of budgeted non-salary expenditures to not less than $85 \%$.

Deliver increased resources to 40 deprived districts: The percentage of Government of Ghana's component of GES non-salary budget for 40 deprived districts increased slightly from $10.1 \%$ in 2003 to $10.2 \%$ in 2004 . However if only GES service expenditure to the deprived districts is considered, then the allocation increased from $7.8 \%$ in 2003 to $12.0 \%$ in 2004.

Increase the execution rate of budgeted non-salary expenditure to not less than 85\%: From January to June 2004 educational expenditure was $34 \%$ of provision; approved cash ceiling was $100 \%$; and expenditure came to $80 \%$ of cash ceiling.

\section{Health}

According to the 2003 GDHS, the achievements of poverty targeted health interventions have so far been mixed. Indicators like infant mortality and child malnutrition showed worrying changes (see also 2003 APR). While access to safe water continues to improve, especially for the rural population, the number of reported guinea worm infections only decreased slightly in 2004 (from 8,290 in 2003 to 7,276 in 2004).

Information on levels of key intermediate health indicators of immunization coverage, antenatal care attendance, and supervised deliveries were available from $\mathrm{MOH} / \mathrm{GES}$ records in 2004. Analysis of the data suggests that, with the exception of supervised deliveries, progress towards improving immunization and antenatal care coverage seems to have stalled in 2004. Immunization coverage barely moved from $76 \%$ in 2003 to $75 \%$ in 2004 ; while antenatal coverage experienced a one percent decrease from $91.2 \%$ in 2003 to $89.2 \%$ in 2004 .

\section{Policy Actions}

Policy measures were implemented in 2004 to strengthen and improve health sector performance. The measures focused on bridging equity gaps in access to health care, improving efficiency in health care delivery and providing financial arrangements that make health care affordable to all Ghanaians. 
Bridge Equity Gaps in Access to Quality Health Care: The specific programmes and projects implemented to achieve health policy objectives were: enhancing infrastructural development to support pro-poor service provision, increasing the coverage of Community Health Planning and Services, providing model hospitals in each targeted deprived district and model health centre in each targeted deprived sub-district. Also included were strengthening and expanding high impact and rapid delivery strategies in service provisions, implementing high impact and rapid delivery programmes to reduce under-five mortality and maternal mortality; assessing health worker attraction and retention programmes; and continuing the process of decentralizing management of human resources, including the identification of options for decentralizing P.E.

Increase the coverage of Community Health Planning and Services (CHPS): Eighteen (18) CHPS compounds were completed in 4 deprived regions at the cost of 10 billion cedis from HIPC funds in 2004. This represents improvement on the 15 such compounds constructed in 2003 in two deprived regions.

Provide one model hospital in each deprived district and at least one model health centre in each identified deprived sub-district: Fifteen health centres and 3 district hospitals were completed for use. Other projects that were either commenced or undertaken to increase access included: preliminary work on 12 sites for upgrading, rehabilitation, and construction of health facilities completed, commencement of the rehabilitation of Bolgatanga and Tamale hospitals, commencement of upgrading and re-equipping of Mamprobi and Kaneshie Polyclinics, upgrading of Juabeso, New Edubiase, and Nkwanta Health Centres to District Hospitals and ; rehabilitation of wards and administrative buildings at Korle-Bu and Okomfo Anokye Teaching Hospitals.

Implement high impact and rapid delivery programmes to reduce under-five mortality and maternal mortality: An assessment was carried out on the programme in UER in 2004 to determine the cost effectiveness of the strategy. Lessons learnt from the study will be used to work out modalities for scaling up the programme in other regions.

Assess bealth profession attraction and retention scheme: A report on health profession attraction and retention has been prepared and discussed. The indicator has therefore been achieved.

Continue the process of decentralizing management of buman resources, including the identification of options for decentralizing P.E: Options paper on decentralizing P.E has been prepared and awaiting discussion with the Ministry of Finance and Economic Planning (MoFEP) before submission to Cabinet for consideration.

Ensure sustainable financing arrangements that protect the poor: Measures implemented in 2004 to achieve this policy objective included accelerating the implementation of the National Health Insurance Scheme and increasing funding and coverage of exemptions to include maternity delivery in two additional regions and exemptions of the poor from fees/health insurance premia

Accelerate the implementation of the National Health Insurance Scheme: The implementation of the NHIS was accelerated in 2004 following the passage of the National Health Insurance ACT 650 in 2003. The achievements in the implementation of the NHIS include: inauguration of the National Health Insurance Programme, establishment of National Health Insurance Council, preparation and subsequent approval of Legislative Instrument 1809, establishment of a permanent NHIS Secretariat. Also included were the appointment of staff for District Mutual Health Insurance Schemes (DMHIS), operationalisation of NHIS in 15 districts, registration and collection of contributions in 78 districts, coding of streets and houses in 16 districts, 
development of accreditation tools for Health Centres, District Hospitals, Regional and Tertiary Hospitals.

As at November, 2004, an approximate amount of four hundred and eighty four billion (484,000, 000,000) cedis has been raised by the National Health Insurance Fund from the various accredited sources.

Coverage of exemptions: Money allocated to exemption in the budget increased from 24 billion cedis in 2003 to 26 billion cedis in 2004 and disbursed to the regions based on target population. Maternal delivery exemptions continued to be implemented in the four deprived regions and were extended to Western and Eastern in 2004. Evidence from the six shows increase in uptake of ANC and supervised delivery indicating that the policy measure has been effective. An amount of 13 billion cedis has also been allocated in the 2005 budget for exemptions from fees/health insurance premia/subsidy for the poor. The criteria for identifying the poor has already been defined in the NHIS Legislative Instrument and DMIS have been requested to register all exempt categories.

\section{Water and Sanitation}

The positive progress registered in enhancing access to safe water for the rural population in 2003 continued in 2004. The proportion of rural population with access to safe water increased from $46.4 \%$ in 2003 to $51.7 \%$ in 2004 , representing about $5 \%$ increase in coverage. The non availability of data on access to sanitation in 2004 made it difficult to track progress in this subsector. The most current information on sanitation access comes from the 2003 Core Welfare Indicator Survey (CWIQ), which showed that access was poor, especially in the deprived northern regions (see 2003 APR).

\section{Policy Actions}

The reported number of cases of guinea worm which has been increasing since 2001 is beginning to decline. The number of reported cases decreased from 8,290 in 2003 to 7,275 in 2004. The endemic regions are Volta, Northern and Brong Ahafo regions. At the district level, the most endemic areas are Tolon-Kumbungu, Savelugu-Nanton, Wa and Nkwanta.

Interventions for preventing the transmission of guinea worm were strengthened in 2004. As at June, 2004, over 40 percent of guinea worm endemic villages had portable water and overall case containment by mid-2004 was $57 \%$ as against a target of $70 \%$ for the year.

Key activities undertaken in 2004 to increase the proportion of rural population with access to safe water and sanitation were the construction of new water points and the rehabilitation of malfunctioning water systems; and supporting deprived districts in preparing water and sanitation plans to guide investments.

Construction of new water points/rehabilitate malfunctioning water systems: There was significant increase the number of new bore holes constructed from 622 in 2002 to 2098 in 2004. Similarly, the number of small community and small town water systems increased from 65 in 2003 to 97 in 2004.

Support deprived districts in preparing water and sanitation plans to guide investments: The NDPC and CWSA completed the production of user-friendly manuals for preparing district water and 
sanitation plans. Fund was secured to print and distribute manuals; and there are also plans to train selected personnel of DAs in the use of manuals and subsequent adoption in developing District Water and Sanitation Plans

\section{GOOD GOVERNANCE}

The practice of good governance in this country is evidently gaining ground. Good governance indicators such as macro-economic stability, a more secured, safe and peaceful country, increased involvement of civil society in policy formulation, implementation and monitoring, increasing private sector productivity and the confidence level of Ghanaians all registered positive growth during the year. This clearly indicates a growing consolidation of the practice of good governance in this country. The conduct of government business and the relationship between state and non-state entities reflect government commitment to the principles of accountability, transparency and participation. Public policy space for civic engagement and private sector participation in the drive to achieve a stable and prosperous country is rapidly expanding.

Almost all the specific benchmarks of good governance reviewed for 2004 registered positive developments as they did in the first two years of the implementation of the GPRS. The areas of policy focus that were reviewed cover a) Security and the Rule of Law and b) Decentralisation, c) Public Sector Reforms and Monitoring and Evaluation of policy implementation.

Crime data for 2004 show marginal drop in crime commission and improvements in public safety. The levels of commonly committed crimes such as assault, stealing and fraud have not registered any significant growth in numbers. Fraud and stealing are on the decline, while assault cases rose only by 0.01 per cent $(3$ cases) over that of the previous year. For the major crimes such as rape and defilement, the country has registered significant drops in reported cases. The declining trend that begun in 2003 with respect to robbery, was reversed with a 5 per cent increase in robbery cases. Murder cases also went up by 4 per cent. This is attributable to increased infiltration of criminal elements from neighbouring countries. Support to the police has enhanced the response rate to crime. Public confidence in the police is rising and cooperation among police and civilians is growing. At the broader national level, the successful conduct of the 2004 elections reflects great progress registered by both the security forces and the citizenry in stabilising internal security. Better policing has resulted from increased resources to the service, growing service staff strength and the creation of Neighbourhood Watch Committees

Improvements have also occurred in the work of other state and non-state governance institutions, in dispensing justice, tackling corruption and in law-making.

With respect to decentralisation, local governance has been brought closer to many more Ghanaians through the creation of new districts. This has increased the opportunity for more citizens to participate directly in political decision-making process. More central government resources (under the DACF and the HIPC Initiative) were released to all districts for the implementation of development projects thus making services available in hard-to-reach and underserved parts of the country. Programmes have been initiated to improve the service conditions of the local government service as well.

Government pursued its objective of strategically positioning state institutions to help the executive discharge its mandate was given a further boost through the review of the barriers to efficient performance under the Public Sector Reform Programme (PSR). Under the PSR also, 
public office holders received training in various fields targeted at improving the quality of service their sectors render to the general public. The Reform is an on-going one.

Policy initiatives to enhance good governance included expanding Neighbourhood Watch Committees, continuing programme of engendering the service, equipping local governance institutions and anti-corruption agencies and generally improving the administration of justice in the country.

\section{THE VULNERABLE AND EXCLUDED}

The government acknowledges that measures need to be instituted to mitigate the effects of shocks on sections of the population that by themselves are incapable of coping and preventing of incidence of certain types of shocks when they occur. Publicly funded social protection schemes that insulate the vulnerable and the excluded ${ }^{3}$ against these threats have become part of public policy. The interventions include a) providing skills for street youth under the Skills Training and Employment Placement Progamme, b) extending social welfare services to women and children who are victims of violence, slavery and abuse, c) making micro-credit available to women and youth under the Women's Development Fund and Youth Development Fund respectively, d) providing free legal aid for the poor, and e) providing counselling and support to persons living with HIV/AIDS. Campaigns on proper sexual behaviour were also intensified. A reduction in the annual prevalence rate to 3.1 per cent (from 3.6\%) has been recorded.

Policy initiatives here include creating more employment opportunities for the youth, women and persons with disability, stepping up campaigns for prevention and control of HIV/AIDS, providing incentives to lawyers to defend the poor and empowering women broadly.

\footnotetext{
${ }^{3}$ The vulnerable and the excluded in this context include among others women and children, persons with disability, HIV positive persons, the extreme poor and the destitute.
} 


\section{CHAPTER ONE}

\section{INTRODUCTION}

\subsection{BACKGROUND}

This is the third Annual Progress Report (APR) on the implementation of the operational development policy framework of the country, the Ghana Poverty Reduction Strategy (GPRS).

The APR provides a structured review of the implementation of programme and projects and their impact on the socio-economic development of the country for a given year. The APR uses a set of indicators, triggers and targets, for monitoring and evaluating the achievements and impacts of the key policy and programme interventions undertaken by the government in 2004, which are aimed at reducing poverty.

Similar to the previous reports, policy recommendations are made for those areas where progress in 2004 has been ineffective. Policy recommendations are also made to address key weaknesses that have been identified in the implementation of the GPRS; which are important inputs to the production of the new four year $(2006-2009)$ development policy framework for the country (the updated GPRS).

The 2004 APR has been compiled based on the summary of achievements during the year and provides:

- the status of implementation of the GPRS communication strategy, Poverty Social Impact Assessments and the Strategic Environment Assessment;

- the linkage between the 2004 Annual Budget and the GPRS;

- the status of policy initiatives mentioned in the 2004 Annual Budget;

- an overview of financial performance of District Assemblies;

- an update on the set of core indicators agreed on in the GPRS M\&E plan including additional indicators identified during the year;

- an update on GPRS Medium Term Priority programmes and projects implemented in 2004;

- the status of policy recommendations made in the 2003 APR;

- the status of triggers and targets of the Poverty Reduction Support Credit (PRSC3)/Multi Donor Budget Support (MDBS) programmes;

- the assessment of performance towards the attainment of the Millennium Development Goals (MDGs).

\subsection{USE OF 2003 APR}

Over the recent years there has been increasing demand for the results of monitoring and evaluation of the GPRS. This was especially so in 2004, since the 2003 APR was a key trigger that had to be achieved for Ghana to meet the HIPC completion point. Thus there was significant demand by the Government and Development Partners for the progress report, and indeed the process was successful.

The 2003 APR was also used to inform the 2005 Annual Budget and the process is reviewed in the next chapter (Linking the Budget to the GPRS). 
The demand for the APR, from other stakeholders however (i.e. MDAs, RCCs, District Assemblies, Parliamentarians, CSOs, Researchers, Media, Public) was lower. During the preparation of this APR the causes for this were investigated, and the following reasons have been identified which have to be addressed in future APRs.

- limited awareness about the contents and process of preparation i.e. document needs to be disseminated more widely

- seen as a technical document i.e. simplified versions required

- thematic perspectives need to be used to facilitate MDA durbars

- Chief Directors are not fully involved in the process thus there is no sense of ownership

- timing of its completion in relation to the national annual budget preparation cycle

- document does not cover all sectors of the economy i.e. focus on GPRS medium term priorities

- regional and district programmes and project interventions are not specifically assessed (i.e. data not disaggregated enough)

- data validation process not thorough enough i.e. there is a need for process to cross check information submitted

\subsection{GPRS M\&E AND CHALLENGES TO DATA COLLECTION}

The data used in the preparation of the APR was obtained primarily from sector ministries, departments and agencies (see references in Appendix). The APR also used data from a Participatory M\&E exercise conducted by NDPC as well as Poverty and Social Impact Assessments (PSIAs) studies. An attempt was made to collect district and regional level indicators however, this proved quite difficult to obtain in a consistent manner. Thus district level disaggregated data on indicator achievements have not been included in this report. A result based M\&E system needs to ensure that the various indicators \& targets at the district and sector level are compatible both between sectors, and at the national level.

The challenges to data collection identified in the 2003 APR still persist. These include:

- lack of feedback and incentives to motivate staff in the MDAs, Regions and Districts to institutionalise M\&E activities;

- inconsistencies in data between the regions and districts;

- challenges of addressing the different M\&E needs of different stakeholders;

- inadequate resources for M\&E at all levels.

Although the M\&E process is deepening, additional resources and attention are required for the national, regional and district level M\&E system to address these shortcomings. Given scarce resources and weaknesses in data collection systems, a "minimal approach" is recommended for GPRS M\&E. It is more effective to collect data on a small set of core indicators and targets, which can reliably reflect annual progress as compared to collecting a lot of unreliable data.

The consultations for validation of data and policy recommendations were intensified during the preparation of 2004 APR. Linkages between MDA-PPME divisions and NDPC are being strengthened and discussions have started on how to increase linkages between sectoral reviews and the APR. The updated GPRS will incorporate an M\&E system, which will ensure that various indicators and targets at district and sector level are compatible both between sectors and at the national level. 
Development Partners (DPs) are also encouraged to harmonize their support to M\&E efforts and to ease the burden on Ministries, Departments and Agency (MDAs) \& District Assemblies (DAs) by limiting their reporting requirements, as they can use the GPRS M\&E process as the major point of reference. For example, various DP programmes support capacity building on $M \& E$ at district levels and these can be harmonised.

To enable more stakeholders and DPs to adopt this approach, it will be crucial to ensure comprehensiveness, reliability, and timeliness of the GPRS M\&E process. This requires additional effort by NDPC, the proposed GPRS M\&E Technical Committee, RPMGs and NIPMGs, etc. in the follow up of the APR 2004.

To enhance ownership and commitment by key stakeholders in government to the M\&E process, it is recommended that, the annual performance contracts, negotiated between the Chief Directors and the Head of Civil Service should include activities linked to relevant indicators of the GPRS M\&E process.

\subsubsection{Participatory M\&E}

Lessons learnt from the preparation of previous annual progress reports indicate that there is a need for empowering the citizenry to fully participate in the M\&E process. Thus a participatory M\&E exercise was undertaken by the NDPC at the end of the $3^{\text {rd }}$ quarter of 2004. The exercise was undertaken to provide an opportunity for citizens to participate in the monitoring and evaluation of the GPRS. This was considered critical given some important findings in the 2003 Annual Progress Report, which included the following;

- increase in childhood mortality in spite of increase resources to the health sector;

- increase in access to safe drinking water alongside increase in incidence of water borne diseases, particularly guinea worm cases;

- poor access to sanitation facilities;

- slow progress in primary school enrolment; and

- a widely held belief that Ghanaians have received limited benefits from reported macroeconomic growth and stability.

The primary objective of the survey was to obtain feedback from citizens about the extent to which the GPRS objective of enhancing access to basic services was being achieved at the community level, and to assess citizens' experience of gains in the macroeconomic sector vis-àvis their living conditions.

The services, which were surveyed included: provision of safe drinking water, provision of adequate sanitation facilities, access to health services and access to primary education. The survey sought information on: access to facilities/services, usage of facilities/services, quality of services, adequacy of services, reliability of services, cost/affordability of services, responsiveness of service providers, overall satisfaction with services, and the impact of macroeconomic reforms on households' livelihoods.

In all 1000 households from four districts were selected for interview. The districts were randomly selected from a sampling frame of 110 districts stratified into three poverty panels:

- Relatively non-poor districts-those with less than $40 \%$ incidence of household poverty.

- Poor districts- those with $40 \%$ to $75 \%$ incidence of household poverty.

- Very poor districts-those with $75 \%$ or more incidence of household poverty. 
In addition, focus group discussions (FGDs) composed of citizens and providers of services were held to complement the survey results. The FGDs were designed to provide information to (a) validate and support the results of the survey and (b) identify areas of immediate concern to households.

A report was produced by NDPC: Citizens' Assessment of the Provision of Basic Services and the Impact of Macroeconomic Stability and the results of the survey have been used in the relevant thematic areas of this report. An increasing number of NGO's/CSO's are also involved in various forms of citizens' assessments. Feedback mechanisms to ensure adequate follow up need to be established for these initiatives.

\subsubsection{Poverty Social Impact Assessments (PSIAs)}

The APR used the results of the five PSIAs which were at different stages of completion. The PSIAs are:

- Economic transformation of the agricultural Sector;

- Tackling vulnerability and exclusion;

- Electricity tariffs;

- Enhancing capacity for pro-poor decentralisation was drafted in 2003 and was still in draft by end of 2004, to be finalized early 2005;

- Petroleum pricing policy (was commissioned and drafted in 2004, to be finalized early 2005).

The purpose of the PSIA's are to: analyse links between GPRS policy reforms, implementation and their poverty impact; review trade-offs between reform initiatives on basis of distributional impact and outcome on welfare; provoke public debate; promote positive effects of reforms under GPRS while minimizing adverse impacts; assess policy reform risks; review implementation of policies and suggest new directions for update of the GPRS.

All the PSIAs have helped to improve understanding of the potential linkages between policies and poverty impact, the need for pro poor targeting, and the importance of identifying specific poor groups, their needs, opportunities, risks, strengths and weaknesses. In all PSIA's, analysis of impact of policy options on poverty and various poor groups, was the major focus. The gender dimension could have been stronger as this is generally an area where more information and more analysis of measures, is needed. Dissemination beyond the PSIA Technical Committees is in most cases yet to take place.

The outcome of the PSIA on Vulnerability was discussed during a workshop with various participants. The initiative has been taken by the Ministry of Manpower Development and Employment to draft a Social Protection Strategy, which will be finalized in 2005. Various DPs have incorporated definitions and issues of the PSIA in the development of their strategies and programmes for Ghana. Both the PSIA and the Common Country Assessment on Vulnerability are being used by the working group which is updating the section on Vulnerability in the GPRS.

The PSIA on Agriculture has also been the subject of various consultations. During a workshop at the end of 2004 with MOFA, NDPC, Cocoa Board, University of Ghana, and DPs (GTZ, DFID, CIDA) decisions were taken on the way forward. A Technical Committee has been set up by MOFA to formulate pro-poor strategies and to identify specific target groups. The Food and Agricultural Sector Development Policy (FASDEP) has been revised accordingly. 
The PSIA on Electricity was finalized in the middle of 2004. There has been no dissemination of the PSIA findings.

The preparatory phase of the PSIA on Petroleum delayed and therefore no final version was ready as at the end of 2004, although public debate on petroleum prices has already started. The report and its recommendations should be able to help arguments linked to poverty reduction in the debates and policy decision making.

The PSIA on Pro-poor decentralisation was still in draft form by end of 2004. In 2004 various consultations took place on the draft. Finalisation and dissemination is expected to take place in 2005, as well as decisions on the follow up.

The follow up actions on conclusions and recommendations from the PSIA's especially impact of pro poor policies need to be closely monitored. Common issues, which are reflected in all PSIA's will be addressed in the updated GPRS (e.g. definitions and causes of poverty, vulnerability, majority of poor who are female, access to services and information, coping strategies of poor people, capacity at district level, and the need for pro-poor targeting).

\subsection{POVERTY MONITORING GROUPS}

The National Interagency Poverty Monitoring Groups (NIPMGs) which include stakeholders from MDAs, DPs and CSOs at national level, were actively involved in the preparation of the APRs. During the year meetings were convened to:

- discuss the role of the NIPMGs;

- nominate $\mathrm{CSO} / \mathrm{NGO}$ representatives per thematic area (based on technical expertise and knowledge);

- brief members on PSIAs; and

- review the 60 core indicators of the GPRS.

The CSOs nominated representatives for the NIPMGs who now fully participate in all NIPMG meetings. The responsibilities and engagement of CSOs in M\&E however, requires further attention. It is recommended that MLGRD and NDPC play an active role in engaging CSOs and defining and fostering working relationships at various levels, including the RPMGs and DPMGs.

Regional Poverty Monitoring Groups (RPMGs) were inaugurated in eight (8) regions in 2004. However, to fulfil their mandate, guidance from national level as well as additional technical and financial resources are required to ensure their role is effective and sustainable. RPMGs also need to prepare yearly work plans, so that gradual improvements can be made, based on a renewed mandate. Linkages and communication channels and procedures with both districts and national level MDAs and NDPC/MLGRD need to be clarified and enhanced. District Poverty Monitoring Groups (DPMGs) have not been set up due to both managerial and financial resource constraints.

As resources will always be scarce, monitoring at district level will need to focus at least at propoor budget expenditures, when M\&E capacity is limited. New programs will be based on a minimum set of baseline data, to enable measuring progress against a limited set of GPRS indicators and targets. The gender dimension of poverty needs further elaboration in analysis, targets, implementation and M\&E (including gender disaggregated data) at all levels. The updated GPRS will need to incorporate a gender sensitive M\&E plan. 


\subsection{GPRS M\&E TECHNICAL COMMITTEE}

The M\&E Technical Committee proposed in the GPRS M\&E Plan has not been established yet. Greater coordination and harmonisation is needed for M\&E activities between the core organisations at the central level (MOFEP, NDPC, OOP, MLGRD, GSS, and OHCS), with a focus on better information flows and incentives to improve GPRS monitoring and evaluation.

The Technical Committee will play a significant role in coordinating the efforts of the core M\&E organisations in defining a new time-table and work plan for $\mathrm{M} \& \mathrm{E}$ activities thus ensuring the close linkage between sectoral reviews, the APR, and budget preparations. The updated GPRS will incorporate an updated GPRS ME plan with the required institutional arrangements and all ME requirements (human, financial and technical).

\subsection{GPRS COMMUNICATION AND DISSEMINATION}

A key mechanism for increasing the demand for the results of $M \& E$ is the quality of communication with stakeholders. Effective communication of the GPRS will ensure that as many Ghanaians as possible, especially the poor, are aware of how the GPRS benefits them, and its role in the national development.

The GPRS Communication strategy developed in 2003 was implemented in 2004 with the following objective "To create a national understanding of the goals, objectives and strategies of the GPRS, and to ensure commitment to, and effective participation of communities, groups and individuals in the implementation of the GPRS".

The GPRS and the APR 2003 were discussed extensively during the National Economic Dialogue in 2004. Another major event was the Ministerial Conference on the Strategic Environmental Assessment of the GPRS. The Development Dialogue Series continued in 2004, various stakeholders (traditional and religious leaders, youth groups, academics, CSOs, NGOs, DPs, DAs, and media) participated in a workshop on social accountability.

The Technical Steering Committee on GPRS Communication supported the training of Regional Trainers to create awareness and commitment on the GPRS and the mechanisms for consultations and feedback in regions and districts. The dissemination of the simplified version of the GPRS which was translated into seven local languages was completed in 2004. MDAs and the media-houses used the translated versions for their dissemination and sensitisation activities. Communication teams and media houses in the regions have been sensitised on the APR 2003 to prepare for radio panel discussions in all regions. The APR was disseminated to all 10 Regional capitals. Journalists and program managers from selected print media houses were also briefed on the GPRS and the APR.

The implementation of the Communication Strategy involved sensitisation of relevant Regional Officers of public institutions and the creation of Regional Communications Teams with the mandate to further disseminate the GPRS and APR (2003) to the district level. The Information Services Department of the Ministry of Information in collaboration with MLGRD conducted community sensitisation programmes on the GPRS and APR, using information vans in all districts in the country.

Some initiatives were taken to launch the NDPC website and some documents were posted. Two GPRS Bulletins were produced in 2004 on HIPC and on Fiscal Decentralisation. 
The necessary feedback obtained from the implementation of the Communication Strategy has been provided to the CSPGs working on the GPRS update. The appendix presents an overview of the feedback on various issues of the GPRS and the 2003 APR from various fora and sources

The proposed GPRS Documentation Centre needs to be set up urgently by NDPC. The scope of work and targets of the Centre should reflect the needs of both decentralized and central institutions, and it would have to pro-actively collect main studies, reports, guidelines, minutes etc (including electronic versions). The Centre should have an active role in updating the GPRS website as well. Pro-active use of the NDPC disclosure policy is necessary to stimulate postings of documents and information on the GPRS website. The World Bank has since 2004 established a Public Information Centre (PIC) in Accra, to facilitate access of stakeholders to available development information ("sharing information and knowledge for a poverty free Ghana"). Close collaboration should be established between the GPRS documentation centre and the Public Information Centre.

\subsection{STRATEGIC ENVIRONMENTAL ASSESSMENT (SEA)}

Ghana is one of the first countries to make use of a $\mathrm{SEA}^{4}$ as a vehicle for reviewing and refining the Poverty Reduction Strategy. The objectives of the SEA were:

- To evaluate to what extent the environment was considered in the GPRS;

- To undertake screening of MDAs policies and District plans and related risks and opportunities for the environment;

- To propose recommendations for mainstreaming environment issues.

The SEA Report was finalized and approved in 2004. Specific recommendations are given for each of the thematic areas of the GPRS with suggestions on rural environment (primary source of more than $50 \%$ of GDP), natural resource conservation, sustainable development, disaster prevention, "green" taxes and accounting, measures to protect the poor and the environment, root causes of lack of gender equity (include women's access to land), environmental health and water, private sector, etc.

During the SEA process, consultations on environmental issues took place with MDAs, CSOs, private sector, parliamentarians, NGOs and DPs. Recommendations have been made for refining policies in order to give more direct focus on environment towards the attainment of sustainable development in the form of advisory notes to MDAs.

Examples of improvements as result of the SEA in the Ministry of Lands and
Forestry:
Recommendation: Broadening the resource base of the wood industry through the increased utilization of the lesser known
and lesser used species (e.g. bamboo, rattan). needs to be linked to various dimensions of poverty. Commitment to resource
regeneration needed. If not, the policy would rather endanger those species and expose streams to evaporation and
pollution/ siltation.
Result: The Ministry has set up Bamboo and Rattan Regeneration Centres to train farmers to go into Bamboo and
Rattan plantations.
Recommendation: Enhancing community based (collaborative) resource management is people, resource and management
targeted, and can assist to improve the lot of the poor.
Result: Community Forest Resource Management Committees are in place.

One hundred and eight District Medium Term Development Plans were appraised on sustainability, and 660 district officials in DAs were trained on this. Districts have been

\footnotetext{
${ }^{4}$ The formalised, systematic and comprehensive process of evaluating the environmental effects of a policy, plan or programme, its alternatives, and/or mitigation measures.
} 
encouraged to address environmental issues and have incorporated actions in their strategies and plans. Regional EPA- and Economic Planning Officers were trained as well, in view of their roles in planning and budgeting.

In May 2004 a Ministerial Conference (with participation of the Vice President, 4 Ministers and a wide range of stakeholders) took place, following various regional conferences, to debate the SEA findings and recommendations. The Vice President expressed government commitment to the SEA process being incorporated into the national development planning process. The following recommendations were made:

- All sector policies to be subjected to SEA;

- SEA principles, processes, findings and recommendations to be integrated in the GPRS and MTEF processes;

- Sector and district guidelines to be infused with SEA principles at national and district levels;

- Comprehensive sector wide SEAs are to be conducted.

The following products were finalized in 2004: The report (in three volumes: Executive Summary, Process Report and Contents Report); The Manual for officers in MDAs, DA's and interested others (NGOs, CSOs, DPs); The NDPC guidelines on SEA and on the update of the GPRS; The Advisory Notes for MDAs; A pictorial brochure on the SEA process; A SEA poster. The printing and dissemination of the SEA products will be carried out in 2005, and guidance for the implementation of SEA tools will be provided by EPA at national and district level. EPA will also be directly involved in the monitoring of the follow up of the SEA recommendations and tools.

A SEA Manual was prepared to ensure that the key elements of SEA and sustainability principles are included the formulation, analysis and refinement of policies and programmes at both sectoral and district levels ${ }^{5}$. Each thematic group for the update of the GPRS will use the Manual, including the matrix to score policies and programs (on the effects on natural resources, social and cultural conditions, the empowerment of women, access of the poor, equity: benefits to be distributed equitably and should not discriminate against any groups, and effects on the local economy). A sustainability test is also included in the Manual. SEA Guidelines were also prepared which aim at MDAs to mainstream environment and integrate SEA principles in their Sector Medium Term Development Plans and M\&E.

The strength of the SEA is that it has incorporated capacity and awareness building at both national, regional and district levels, is integrated in the NDPC planning process and, through its systematic approach, and provides an example for assessment of other governmental policies. It brought to the fore in a practical way the crucial link between poverty and environment in the drive towards poverty reduction.

\subsection{RECOMMENDATIONS IN APR 2003 ON GPRS MONITORING AND EVALUATION}

Table 1.1 below shows a summary of the key recommendations made in APR 2003 on GPRS monitoring and evaluation.

\footnotetext{
${ }^{5}$ The SEA Manual contains the tools used for assessing risks and opportunities on policies, plans and programs, related to the environment.
} 
Table 1.1: Recommendations in APR 2003 on GPRS Monitoring and Evaluation

\begin{tabular}{|c|c|c|}
\hline Recommendations in APR 2003 & Progress in 2004 & Required follow up in 2005 \\
\hline NIPMGs operational & $\begin{array}{l}\text { NIPMGs were involved in provision/ } \\
\text { validatio of data for APR's }\end{array}$ & $\begin{array}{l}\text { Strong leadership will be provided by chairpersons from MDAs. MLGRD/NDPC will } \\
\text { provide guidance to ensure fulfilment mandate by NIPMGs and their active role in GPRS } \\
\text { M\&E. }\end{array}$ \\
\hline Civil society included in $\mathrm{M} \& \mathrm{E}$ process & $\begin{array}{l}\text { NIPMG meeting held to nominate } \\
\text { CSO representatives in NIPMGs }\end{array}$ & $\begin{array}{l}\text { Roles of CSOs will be discussed and defined by CSOs, NIPMGs, RPMGs and } \\
\text { MLGRD/NDPC, and working relationships will be fostered . }\end{array}$ \\
\hline RPMGs operational & $\begin{array}{l}\text { Inaugurated in } 2004 \text { but not yet } \\
\text { operational }\end{array}$ & $\begin{array}{l}\text { As resources will always be scarce, monitoring at district level will need to focus at least at } \\
\text { pro-poor budget expenditures. Guidance, feedback and support will be provided by } \\
\text { MLGRD/NDPC to enable RPMGs to fulfil mandate. }\end{array}$ \\
\hline $\begin{array}{l}\text { Implementation of GPRS } \\
\text { Communication strategy } \\
\text { (Note: see also par. 1.5. on } \\
\text { Communication) }\end{array}$ & $\begin{array}{l}\text { NED and Ministerial Conference on } \\
\text { SEA successful; Workshop on training } \\
\text { of trainers from } 10 \text { regions took place }\end{array}$ & $\begin{array}{l}\text { Follow up activities will be guided by NDPC (including GPRS website) and GPRS Sub- } \\
\text { Committee on Communication. The Communication strategy, plan and budget will be } \\
\text { incorporated in the updated GPRS, and will be guided by NDPC. } \\
\text { The various GPRS Committees (including RPMGs and NIPMGs) will be encouraged to } \\
\text { use the communication channels, identified in the Communication Needs Assessment. } \\
\text { The Quarterly GPRS ME Bulletins are strong tools in creating commitment, stimulating } \\
\text { debate, and deepening/broadening understanding of poverty and GPRS issues. The } \\
\text { Bulletins will be produced regularly for various target groups, and disseminated widely } \\
\text { accordingly. } \\
\text { The GPRS Documentation Centre will be set up in NDPC }{ }^{6} \text {. The scope of work and } \\
\text { targets of the Centre will reflect the needs of both decentralized and central institutions, } \\
\text { and will also include electronic versions of documents, reports etc. } \\
\text { The Centre will play a pivotal role in maintaining the GPRS website. }\end{array}$ \\
\hline $\begin{array}{l}\text { PSIA to findings influence policy making } \\
\text { and provoke public debate on these } \\
\text { policies }\end{array}$ & $\begin{array}{l}\text { PSIAs finalized in } 2004 \text { (except PSIAs } \\
\text { on Pro Poor Decentralisation and } \\
\text { Petroleum pricing policy). } \\
\text { Findings/recommendations were } \\
\text { discussed in PSIA Technical }\end{array}$ & $\begin{array}{l}\text { Dissemination plans will be implemented and guided by NDPC. Lead MDAs will ensure } \\
\text { incorporation of recommendations in poverty policies and in updated GPRS. Crucial } \\
\text { factor to determine success of revised pro poor policies will be the results and impact of } \\
\text { implementation on the poor. }\end{array}$ \\
\hline
\end{tabular}

\footnotetext{
${ }^{6}$ Some examples: Guidelines and Manuals on SEA, PSIAs, the various GPRS programs, ME-initiatives (ME guidelines for Districts and Regions and documents/membership of RPMGs, NIPMGs), pilot ME
} programs, the APR process and outcome, as reference point for future ME requirements and activities. 


\begin{tabular}{|c|c|c|}
\hline Recommendations in APR 2003 & Progress in 2004 & Required follow up in 2005 \\
\hline & $\begin{array}{l}\text { Committees, no wide dissemination } \\
\text { yet. }\end{array}$ & $\begin{array}{l}\text { Explicit attention will be given to the monitoring of outputs and impact of pro poor } \\
\text { policies as result of PSIAs, including the GPRS objective of gender equality and women's } \\
\text { empowerment. } \\
\text { Common issues, which are reflected in all PSIAs, will be addressed in the updated GPRS } \\
\text { (e.g. definitions and causes of poverty and vulnerability, majority of poor who are female, } \\
\text { access of poor to services and information, coping strategies of poor people, capacity at } \\
\text { district level, and the need for pro-poor targeting). }\end{array}$ \\
\hline $\begin{array}{l}\text { Feedback system so that ME findings } \\
\text { target district, regional, national level, } \\
\text { MDAs, Cabinet and Parliament }\end{array}$ & Not yet & $\begin{array}{l}\text { MLGRD/NDPC/MOFEP (and ME Technical Committee once established) will } \\
\text { elaborate feedback system, including dissemination of selected summaries of APR } \\
\text { findings and recommendations for selected groups. Guidance on ME systems and } \\
\text { indicators, and responsibilities, will be incorporated in the updated GPRS and supported } \\
\text { by MLGRD and NDPC. }\end{array}$ \\
\hline $\begin{array}{l}\text { Additional activities to strengthen } \\
\text { feedback system: } \\
\text { - review workshops to improve ME } \\
\text { process } \\
\text { orientation sessions with policy } \\
\text { makers in MDAs }\end{array}$ & Not yet & $\begin{array}{l}\text { MLGRD/NDPC/MOFEP will coordinate this, including guidance on ways to harmonize } \\
\text { various ME systems and improved communication and feedback channels. Feedback and } \\
\text { incentive systems will need to be incorporated in the ME systems. }\end{array}$ \\
\hline $\begin{array}{l}\text { M\&E Technical Committee to be set up } \\
\text { according to GPRS M\&E Plan }\end{array}$ & Not yet & $\begin{array}{l}\text { To be set up by MLGRD/NDPC/MOFEP/ } \\
\text { OOP/GSS/MOWAC, also to lead and guide GPRS ME systems, activities and } \\
\text { committees }\end{array}$ \\
\hline $\begin{array}{l}\text { Key M\&E results and GPRS Quarterly } \\
\text { Bulletins with M\&E results to be } \\
\text { available and to be used for preparation } \\
\text { of } 2005 \text { Budget }\end{array}$ & $\begin{array}{l}3 \text { Quarterly bulletins produced on } \\
\text { fiscal decentralisation, HIPC and } \\
\text { Participatory M\&E (Citizens } \\
\text { Assessment). }\end{array}$ & $\begin{array}{l}\text { NDPC will guide the use of ME results and information, as well as follow up of } \\
\text { recommendations (ME Technical Committee and Communication Sub Committee to play } \\
\text { an active role, once established). } \\
\text { The results of the Participatory M\&E have not been disseminated, thus in } 2005 \text { NDPC } \\
\text { will disseminate the results to the districts involved in the survey. Follow up } \\
\text { recommendations will also be discussed both at district and at national level. }\end{array}$ \\
\hline
\end{tabular}




\subsection{SUMMARY OF PROGRESS - GPRS CORE INDICATORS}

Table 1.2 below shows a summary of the progress made so far on the GPRS core indicators.

Table 1.2: GPRS Core Indicators

\begin{tabular}{|c|c|c|c|c|c|}
\hline Indicator & Target & $\begin{array}{c}\text { Indicator Level } \\
2002\end{array}$ & $\begin{array}{c}\text { Indicator Level } \\
2003\end{array}$ & Status 2004 & $\begin{array}{c}\text { Progress } \\
\text { towards } \\
\text { Target } \\
\end{array}$ \\
\hline \multicolumn{6}{|l|}{ MACROECONOMIC STABILITY } \\
\hline Real Per capita GDP growth rate & $2.1 \%$ & $1.8 \%$ & $2.6 \%$ & $3.2 \%$ & Target exceeded \\
\hline Food Price Inflation & $15 \%$ & $22 \%$ & 21.5 & $15.5 \%$ & Target exceeded \\
\hline Growth of Domestic revenue & $\mathrm{N} / \mathrm{A}$ & $28.8 \%$ & $56.2 \%$ & $38.24 \%$ & - \\
\hline Growth of Credit to Agriculture & $\mathrm{N} / \mathrm{A}$ & $9.04 \%$ & $51.12 \%$ & $20.6 \%$ & - \\
\hline $\begin{array}{l}\text { Timely Disbursement of Budgeted MDA } \\
\text { allocation }\end{array}$ & $\mathrm{N} / \mathrm{A}$ & $\mathrm{N} / \mathrm{A}$ & $\mathrm{N} / \mathrm{A}$ & $\mathrm{N} / \mathrm{A}$ & $\mathrm{N} / \mathrm{A}$ \\
\hline $\begin{array}{l}\text { Proportion of total resources going to key } \\
\text { GPRS sectors }\end{array}$ & 64.75 & 79.6 & 74.78 & $\mathrm{~N} / \mathrm{A}$ & $\mathrm{N} / \mathrm{A}$ \\
\hline Real Per capita Agric growth rate & $1.9 \%$ & $1.8 \%$ & $3.5 \%$ & $4.9 \%$ & Target exceeded \\
\hline Real Per capita Food Crop growth rate & $2.2 \%$ & $2.6 \%$ & $2.7 \%$ & 2.8 & Target exceeded \\
\hline \multicolumn{6}{|l|}{$\begin{array}{l}\text { PRODUCTION \& GAINFUL } \\
\text { EMPLOYMENT }\end{array}$} \\
\hline$\%$ of post harvest losses & $15-20 \%$ & $\begin{array}{l}\text { Cereals: } 25-30 \% \\
\text { Perishables:35-40\% }\end{array}$ & $\begin{array}{l}20-25 \% \text { (cereals) } \\
35-38 \% \text { (perishables) }\end{array}$ & $\begin{array}{l}15-20 \% \\
33-35 \%\end{array}$ & $\begin{array}{l}\text { Target achieved } \\
\text { for cereals } \\
\text { Modest } \\
\text { progress made } \\
\text { on perishables }\end{array}$ \\
\hline Tons of major crops produced & $\mathrm{N} / \mathrm{A}$ & $\mathrm{N} / \mathrm{A}$ & $\begin{array}{l}\text { Maize }=1.29 \mathrm{~m} \mathrm{Mt} \\
\text { Rice }=0.239 \mathrm{~m} \mathrm{Mt} \\
\text { Millet }=0.176 \mathrm{~m} \mathrm{Mt} \\
\text { Sorghum }=0.338 \mathrm{~m} \mathrm{Mt} \\
\text { Cassava }=10.2 \mathrm{~m} \mathrm{Mt} \\
\text { Yam }=3.8 \mathrm{~m} \mathrm{Mt} \\
\text { Plantain }=2.3 \mathrm{~m} \mathrm{Mt}\end{array}$ & $\begin{array}{l}\text { Maize }=1.16 \mathrm{~m} \mathrm{Mt} \\
\text { Rice }=0.242 \mathrm{~m} \mathrm{Mt} \\
\text { Millet }=0.144 \mathrm{Mt} \\
\text { Sorghum }=0.287 \mathrm{~m} \mathrm{Mt} \\
\text { Cassava }=9.7 \mathrm{~m} \mathrm{Mt} \\
\text { Yam }=3.89 \mathrm{~m} \mathrm{Mt} \\
\text { Plantain }=2.38 \mathrm{~m} \mathrm{Mt}\end{array}$ & Mixed result \\
\hline Extension officer farmer ratio & 1:1200 & $1: 2200$ & $1: 1,500$ & $1: 1,400$ & On target \\
\hline Area under fish farm & 450ha & $350-400 \mathrm{ha}$ & 450ha & $\begin{array}{l}112.3 \text { ha Functional fish ponds } \\
2480.8 \text { ha reservoirs }\end{array}$ & Target exceeded \\
\hline
\end{tabular}




\begin{tabular}{|c|c|c|c|c|c|}
\hline Indicator & Target & $\begin{array}{l}\text { Indicator Level } \\
2002\end{array}$ & $\begin{array}{l}\text { Indicator Level } \\
2003\end{array}$ & Status 2004 & $\begin{array}{c}\text { Progress } \\
\text { towards } \\
\text { Target } \\
\end{array}$ \\
\hline Percent of arable land under irrigation & $0.12 \%(33,000 \mathrm{ha})$ & $0.04 \%(11,000 \mathrm{ha})$ & currently estimated at $0.08 \%$ & $0.08 \%$ & No progress \\
\hline Number of dugouts constructed & 1,309 & 237 & $\begin{array}{l}713 \text { out of } 1309 \text { (bore holes, } \\
\text { dugouts, water storage, } \\
\text { stream diversion, stream and } \\
\text { tube well pumping) were } \\
\text { completed }\end{array}$ & $\begin{array}{l}999 \text { out of the } 1,309 \text { water facilities were } \\
\text { constructed. }\end{array}$ & Good progress \\
\hline Farmer access to mechanized tillage & $15 \%$ & Less than $5 \%$ & $8 \%$ & $12 \%$ & On track \\
\hline Access to harvesters & $5 \%$ & Less than $2 \%$ & $2 \%$ & $2 \%$ & No progress \\
\hline Access to processing equipment & $30 \%$ & $20 \%$ & $24 \%$ & $42 \%$ & Target exceeded \\
\hline Rate of deforestation & & 65,000 per year & 50,000 per year & $\begin{array}{l}\text { Less than 50,000(yet to be } \\
\text { determined).measured every } 10 \\
\text { Years. }\end{array}$ & $\begin{array}{l}\text { Some progress } \\
\text { made }\end{array}$ \\
\hline Number of CRMAS* established & 2 & 1 & 1 & - & No progress \\
\hline Ha of degraded forest reserve planted & $\begin{array}{l}60,000 \text { by } \\
2008\end{array}$ & & $25,691 \mathrm{ha}$ & $\begin{array}{l}\text { 27,050(HIPC plantation-10950) } \\
\text { (forestry commission-16100) }\end{array}$ & Good progress \\
\hline Number of current land cases concluded & $\begin{array}{l}\text { Reduced by } \\
35,000 \\
(2008)\end{array}$ & 60000 currently in court & $\begin{array}{l}\text { Alternative Dispute } \\
\text { Resolution commences in } \\
\text { 2nd Quarter }\end{array}$ & On Going/ land Courts being built & $\begin{array}{l}\text { Some progress } \\
\text { made }\end{array}$ \\
\hline No. of schools provided with ICT & 514 by 2005 & 0 & 257 & 360 & Good progress \\
\hline No. of fixed telephone lines installed & 400,000 by 2005 & 200,000 & 283,000 & $\begin{array}{l}\text { Fixed Line:315,682 } \\
\text { (Cellular: 1,540,476 } \\
\text { Pay-Phones:9,933) } \\
\end{array}$ & On track \\
\hline $\begin{array}{l}\text { People with access to non-wood fuel } \\
\text { energy(over } 68 \% \text { of total energy consumed } \\
\text { in Ghana is from wood fuels) }\end{array}$ & $\mathrm{N} / \mathrm{A}$ & - & $43.4 \%$ & $\begin{array}{l}40 \% \text { (SNEP) } \\
\text { Petroleum: } 29 \% \\
\text { Electricity : } 11 \% \\
\end{array}$ & On course \\
\hline $\begin{array}{l}\text { Lifeline pricing for electricity sector } \\
\text { developed and implemented }\end{array}$ & $\mathrm{N} / \mathrm{A}$ & & Done & done & done \\
\hline Length of motorable feeder roads & $\mathrm{N} / \mathrm{A}$ & & $32,601.8 \mathrm{~km}$ & $23,000 \mathrm{~km}$ & On course \\
\hline Feeder road contract time lag & $\mathrm{N} / \mathrm{A}$ & & $\mathrm{N} / \mathrm{A}$ & $\mathrm{N} / \mathrm{A}$ & \\
\hline $\begin{array}{l}\text { Number of Small Scale agro-processing } \\
\text { firms }\end{array}$ & $\mathrm{N} / \mathrm{A}$ & & $\mathrm{N} / \mathrm{A}$ & $\mathrm{N} / \mathrm{A}$ & \\
\hline Number of functioning employment centres & $\mathrm{N} / \mathrm{A}$ & & $\mathrm{N} / \mathrm{A}$ & 62 & On course \\
\hline
\end{tabular}




\begin{tabular}{|c|c|c|c|c|c|}
\hline Indicator & Target & $\begin{array}{l}\text { Indicator Level } \\
2002\end{array}$ & $\begin{array}{l}\text { Indicator Level } \\
2003\end{array}$ & Status 2004 & $\begin{array}{c}\text { Progress } \\
\text { towards } \\
\text { Target }\end{array}$ \\
\hline \multicolumn{6}{|l|}{$\begin{array}{l}\text { HUMAN RESOURCE } \\
\text { DEVELOPMENT }\end{array}$} \\
\hline Gross primary enrolment ratio & 88.5 & $83.8 \%$ & $85.7 \%$ & $86.3 \%$ & Likely \\
\hline $\begin{array}{l}\text { Percent of deprived basic schools improved, } \\
\text { with emphasis on the three northern regions } \\
\text { (Share of the three northern regions in } \\
\text { number of } \\
\text { constructed/rehabilitated) }\end{array}$ & & $\mathrm{N} / \mathrm{A}$ & $\begin{array}{l}420 \text { of } 685(61.3 \%) \text { of } 3 \text {-unit } \\
\text { classrooms constructed were } \\
\text { located in the } 3 \text { Northern } \\
\text { regions }\end{array}$ & $\begin{array}{l}96 \text { out of the } 440 \text { 6-unit }(22 \%) \\
\text { classroom blocks under construction } \\
\text { were located in the three northern } \\
\text { regions }\end{array}$ & $\begin{array}{l}\text { Decline in } \\
\text { percent share of } \\
\text { new classrooms } \\
\text { constructed }\end{array}$ \\
\hline $\begin{array}{l}\text { Percentage of trained teachers in primary } \\
\text { schools }\end{array}$ & 81.3 & 69.9 & 73.5 & 73.9 & Unlikely \\
\hline Survival rate to P6 and JSS 3 & $\mathrm{~N} / \mathrm{a}$ & $\mathrm{N} / \mathrm{a}$ & $\mathrm{N} / \mathrm{a}$ & $\mathrm{N} / \mathrm{a}$ & $\begin{array}{ll}------ \\
\end{array}$ \\
\hline Infant mortality rate & & $57(1998)$ & 64 & $\mathrm{~N} / \mathrm{A}$ & Worsening \\
\hline $\begin{array}{r}\text { Immunization Coverage } \\
\mathrm{MOH} \\
\end{array}$ & $90.0 \%$ & 77.9 & 76.0 & 75.0 & Not on track \\
\hline GDHS & & $62(1998)$ & 69.4 & $\mathrm{~N} / \mathrm{A}$ & \\
\hline $\begin{array}{l}\text { Child malnutrition } \\
\text { ( } \% \text { of children underweight) }\end{array}$ & & $25(1998)$ & 35.8 & $\mathrm{~N} / \mathrm{A}$ & Worsening \\
\hline $\begin{array}{l}\text { Proportion of supervised deliveries } \\
\mathrm{MOH}\end{array}$ & $55.0 \%$ & 44.3 & 51.9 & 53.4 & On track \\
\hline GDHS & & $44.3(1998)$ & 47.1 & $\mathrm{~N} / \mathrm{A}$ & \\
\hline $\begin{array}{l}\text { Health expenditure increased from } 5.7 \text { in } \\
2000 \text { to } 7 \% \text { of total government expenditure } \\
\text { in } 2003\end{array}$ & $7.0 \%$ & $10.5 \%$ & $11.8 \%$ & $12.0 \%$ & On Track \\
\hline $\begin{array}{l}\text { At least } 10 \% \text { increase in amount budgeted } \\
\text { for exemptions }\end{array}$ & $\begin{array}{ll}--- \\
-1\end{array}$ & $21 \%$ & $24 \%$ & $26 \%$ & On track \\
\hline $\begin{array}{l}\text { Number of new functional water systems } \\
\text { Boreholes } \\
\text { Wells } \\
\text { Pipes }\end{array}$ & ---- & $\begin{array}{l}622 \\
65 \\
29 \\
\end{array}$ & $\begin{array}{l}1290 \\
61 \\
65\end{array}$ & $\begin{array}{l}2098 \\
64 \\
97 \\
\end{array}$ & On track \\
\hline $\begin{array}{l}\text { Percent of rural population with access to } \\
\text { safe water (CWSA) }\end{array}$ & $46.0 \%$ & $40 \%$ & 46.4 & 51.7 & On track \\
\hline $\begin{array}{l}\text { Percent of rural population with access to } \\
\text { safe sanitation (CWIQ) }\end{array}$ & $\begin{array}{l}---- \\
\end{array}$ & $45.8 \%$ & $55.0 \%$ & Not available & $\begin{array}{ll}\text { Difficult } & \text { to } \\
\text { assess due } & \text { to }\end{array}$ \\
\hline
\end{tabular}




\begin{tabular}{|c|c|c|c|c|c|}
\hline Indicator & Target & $\begin{array}{l}\text { Indicator Level } \\
2002\end{array}$ & $\begin{array}{c}\text { Indicator Level } \\
2003\end{array}$ & Status 2004 & $\begin{array}{c}\text { Progress } \\
\text { towards } \\
\text { Target } \\
\end{array}$ \\
\hline & & & & & lack of data \\
\hline Reported number of guinea worm cases & 0 & 5,611 & 8.290 & 7,275 & $\begin{array}{l}\text { Slight deduction } \\
\text { in the number } \\
\text { of cases }\end{array}$ \\
\hline \multicolumn{6}{|l|}{$\begin{array}{l}\text { GOOD GOVERNANCE \& } \\
\text { VULNERABILITY ANDEXCLUSION }\end{array}$} \\
\hline Incidence of poverty & $32 \%$ & $39 \%-(2000)$ & $\mathrm{N} / \mathrm{A}$ & $\mathrm{N} / \mathrm{A}$ & - \\
\hline Incidence of extreme poverty & $21 \%$ & $27 \%$ & $-\mathrm{N} / \mathrm{A}$ & $-\mathrm{N} / \mathrm{A}$ & - \\
\hline HIV/AIDS Prevalence & $3.6 \%$ & $3.8 \%$ & $3.4 \%$ & $3.6 \%$ & On track \\
\hline $\begin{array}{l}\text { Accessibility of services (disaggregated to } \\
\text { services, region, districts) }\end{array}$ & & & $\begin{array}{l}\text { Some data is available from } \\
\text { the } 2003 \text { CWIQ, but not } \\
\text { enough to establish levels }\end{array}$ & $\begin{array}{l}\text { Some data is available from the } 2003 \\
\text { CWIQ, but not enough to establish } \\
\text { levels }\end{array}$ & - \\
\hline $\begin{array}{l}\text { Access of extreme poor to services } \\
\text { (disaggregated to services, region, districts }\end{array}$ & & & $\begin{array}{l}\text { Some data is available from } \\
\text { the } 2003 \text { CWIQ, but not } \\
\text { enough to establish levels }\end{array}$ & $\begin{array}{l}\text { Some data is available from the } 2003 \\
\text { CWIQ, but not enough to establish } \\
\text { levels }\end{array}$ & - \\
\hline $\begin{array}{l}\text { Drug based treatment available for people } \\
\text { with AIDS }\end{array}$ & & & $\begin{array}{l}\text { 4 Sentinel Sites are providing } \\
\text { ART for PLWHA and } 19 \\
\text { sentinel site are implementing } \\
\text { a programme for the } \\
\text { prevention of mother to } \\
\text { child transmission }\end{array}$ & $\begin{array}{l}4 \text { facilities were established by mid-year } \\
\text { as against the target of } 6 \text { by the end of } \\
2004 \text { to provide antiretroviral therapy } \\
\text { (ART) to AIDS patients. } \\
1176 \text { patients had been put on ART by } \\
\text { mid-year as against the targeted } 2,000 \text { for } \\
\text { the full year. } \\
29 \text { Voluntary Council and Testing } \\
\text { Centres (VCT) as against the targeted } 66 \\
\text { VCT centres were established by mid- } \\
\text { year; } \\
302 \text { mother-baby pairs were treated with } \\
\text { Niverapine by mid-year as against the } \\
\text { target of } 6,000 \text { mother-baby pairs for } \\
2004 \text {. }\end{array}$ & On track \\
\hline $\begin{array}{l}\text { Adequate security and protection for } \\
\text { women and children }\end{array}$ & & 5,516 cases handled by WAJU & $\begin{array}{l}6,298 \text { cases handled by } \\
\text { WAJU. WAJU established in } \\
\text { all Regions, Desk office in } \\
\text { Odorkor and Dansoman and }\end{array}$ & $\begin{array}{l}11982 \text { cases were handled by WAJU. In } \\
\text { addition to the regional offices, WAJU } \\
\text { has } 3 \text { divisional offices in Greater Accra, } \\
2 \text { in Brong Ahafo, } 3 \text { in the Eastern }\end{array}$ & On-track \\
\hline
\end{tabular}




\begin{tabular}{|c|c|c|c|c|c|}
\hline Indicator & Target & $\begin{array}{l}\text { Indicator Level } \\
2002\end{array}$ & $\begin{array}{l}\text { Indicator Level } \\
2003\end{array}$ & Status 2004 & $\begin{array}{c}\text { Progress } \\
\text { towards } \\
\text { Target } \\
\end{array}$ \\
\hline & & & a District Office in Swedru & region and 1 in Central region. & \\
\hline $\begin{array}{l}\text { Budgets available to institutions caring for } \\
\text { vulnerable and Excluded }\end{array}$ & & $\begin{array}{l}\text { MOWAC received } \\
\not 6.079 \text { billion in } 2002\end{array}$ & $\begin{array}{l}\text { MOWAC received } \\
£ 9.669 \text { billion in } 2003\end{array}$ & $\begin{array}{l}\text { MOWCA received } ₫ 20,563 \text { billion in } \\
2004\end{array}$ & - \\
\hline $\begin{array}{l}\text { Appropriate indicators developed to } \\
\text { monitor change in well being of vulnerable } \\
\text { and excluded, across the entire GPRS }\end{array}$ & & & $\begin{array}{l}\text { PSIA currently on going and } \\
\text { indicators are being } \\
\text { developed }\end{array}$ & $\begin{array}{l}\text { A social protection strategy policy is } \\
\text { currently being developed for the } \\
\text { vulnerable and excluded }\end{array}$ & On track \\
\hline $\begin{array}{l}\text { Level of perceived corruption in key GPRS } \\
\text { functional areas }\end{array}$ & & & No survey conducted yet & & - \\
\hline $\begin{array}{l}\text { Government Expenditure Reports } \\
\text { published }\end{array}$ & & & $\begin{array}{l}\text { Report published monthly in } \\
\text { gazette }\end{array}$ & & On track \\
\hline Local safety and security institutions in place & $\begin{array}{l}\text { 1:925 by } 2004 \\
\text { police/citizen } \\
\text { ratio }\end{array}$ & 1:1142 & $\begin{array}{l}\text { 1:1,121 } \\
\text { police / citizen ratio }\end{array}$ & 1:1055 & $\begin{array}{l}\text { Not on track } \\
\text { but gradually } \\
\text { moving towards } \\
\text { target }\end{array}$ \\
\hline $\begin{array}{l}\text { Dissemination of Parliamentary debates on } \\
\text { poverty and development }\end{array}$ & & & $\begin{array}{l}\text { Dissemination occurred } \\
\text { through interaction with unit } \\
\text { committee members, mass } \\
\text { and print media. }\end{array}$ & & On track \\
\hline Utilization of Legal Aid Services & & 4225 & $\begin{array}{l}4500 \text { cases -Utilization by } \\
\text { poor increasing but not } \\
\text { adequate }\end{array}$ & $\begin{array}{l}5590 \text { applied for legal Aid services and } \\
5090 \text { received legal aid services. Legal } \\
\text { Aid Services can now be received nation } \\
\text { wide }\end{array}$ & On track \\
\hline Functioning Electronic Tracking System & $\begin{array}{l}\text { Expand the } \\
\text { Government's } \\
\text { computerized } \\
\text { financial and } \\
\text { accounting } \\
\text { system to cover } \\
\text { additional four } \\
\text { (4) MDAs }\end{array}$ & & $\begin{array}{l}2 \text { MDAs Established in } \\
\text { MOFEP \& CAGD }\end{array}$ & $\begin{array}{l}\text { Currently, set up of Oracle Financials as } \\
\text { a centralised solution is } 100 \% \text { complete } \\
\text { in both test and production instance for } \\
\text { the following MDAs' headquarters: } \\
\text { - Ministry of Finance } \\
\text { - Controller \& Accountant General } \\
\text { - Ministry of Health Headquarters } \\
\text { - Ghana Health Service Headquarters } \\
\text { - Ministry of Interior -headquarters } \\
\text { - Ministry of Education, Youth and } \\
\text { - Sports Headquarters } \\
\text { Ghana Education Service } \\
\text { Headquarters }\end{array}$ & On track \\
\hline
\end{tabular}




\begin{tabular}{|c|c|c|c|c|c|}
\hline Indicator & Target & $\begin{array}{l}\text { Indicator Level } \\
2002\end{array}$ & $\begin{array}{l}\text { Indicator Level } \\
2003\end{array}$ & Status 2004 & $\begin{array}{c}\text { Progress } \\
\text { towards } \\
\text { Target } \\
\end{array}$ \\
\hline & & & & $\begin{array}{l}\text { - Ministry of Roads and Transport } \\
\text { Headquarters }\end{array}$ & \\
\hline Composite budget developed and submitted & & Yet to be implemented & $\begin{array}{l}3 \text { pilot districts. Action was } \\
\text { initiated } 3 \text { pilot districts - } \\
\text { Dangme East and West and } \\
\text { Akuapem North }\end{array}$ & $\begin{array}{l}\text { The integrated planning and composite } \\
\text { budgeting pilot is implemented } \\
\text { according to schedule. In addition to the } \\
3 \text { districts where the pilot is currently } \\
\text { being implemented, } 22 \text { more districts } \\
\text { have been tentatively selected ( } 2 \text { from } \\
\text { each region, but excluding the newly } \\
\text { created districts and the districts that } \\
\text { these were carved from.) }\end{array}$ & On track \\
\hline $\begin{array}{l}\text { Parliamentary Committee } \\
\text { Reduction established }\end{array}$ & $\begin{array}{l}\text { Committee to be } \\
\text { set up in } 2002\end{array}$ & $\begin{array}{l}\text { Ad hoc Committee } \\
\text { Established and discussed the } \\
\text { GPRS Document }\end{array}$ & $\begin{array}{l}\text { Ad hoc Committee in place } \\
\text { and met in November. } \\
\text { Efforts are being made to } \\
\text { make it a Standing } \\
\text { Committee }\end{array}$ & $\begin{array}{l}\text { The committee organized a workshop } \\
\text { from 15th to } 17 \text { th September } 2004 \text { to } \\
\text { discuss the } 2002 \text { and } 2003 \text { APR prior to } \\
\text { their being laid before Parliament. }\end{array}$ & Achieved \\
\hline $\begin{array}{l}\text { Democratic effectiveness of the District } \\
\text { Assemblies }\end{array}$ & $\begin{array}{l}\text { Increase } \text { DACF } \\
\text { to } 7.5 \% \text { of Tax } \\
\text { Revenue }\end{array}$ & $5 \%$ & $\begin{array}{l}\text { DACF increased to } 7.5 \% \text {. } \\
\text { All DAs meet regularly as } \\
\text { enshrined in the LIs. }\end{array}$ & & Achieved \\
\hline Policy Feedback from M\&E system & & $\begin{array}{l}2002 \text { Annual Progress Report, } \\
\text { Communication Strategy, } \\
\text { Quarterly Bulletin, } 2002 \text { APR } \\
\text { was used to influence } 2004 \\
\text { budget }\end{array}$ & 2003 APR prepared. & $\begin{array}{l}2004 \text { APR prepared. } \\
\text { Social Protection strategy and Citizens } \\
\text { Report Card on basic services and } \\
\text { macroeconomic stability were prepared } \\
\text { in } 2004\end{array}$ & On track \\
\hline
\end{tabular}

Note for Table

1. The GPER is calculated from EMIS census returns. As the return rates for target groups vary by year (94\% for 2002-03 and $95.5 \%$ in $2003-04)$, direct year on year comparison is compromised. The GPER figures in the Table have therefore been scaled up to 100\% for all years presented to provide a more accurate and less variable data for assessing education performance.

2. The GPER figures in Tables 5.3 in the 2003 APR are consequently amended.

3. To discern trends in the intermediate indicators of immunization coverage and supervised deliveries, data from the MOH is used here. The levels may not therefore be the same as those of 2003 GDHS which informed the 2003 APR 


\section{CHAPTER TWO}

\section{THE LINKS BETWEEN THE GPRS AND THE 2004 BUDGET}

\subsection{INTRODUCTION}

The 2002 and 2003 Annual Progress Reports discussed the extent to which the Budgets reflected the policy thrust of the GPRS. This was to give an indication of whether government is persistent in its poverty reduction strategy and whether resources are allocated appropriately. This part of the 2004 Annual Progress Report looks at whether the 2004 Budget reflected the thrust of the GPRS, and the actual discretionary expenditures of 2004.

The assessment of the consistency of the budget with the GPRS will be from the perspective of:

- The budget process;

- The extent to which the macro-framework provided by the budget was consistent with the GPRS;

- The distribution of total budgetary allocations;

- Sectoral distribution of Government of Ghana's (GoG) resources;

- Distribution of donor allocations

- The distribution of expenditures by item of expenditure (i.e., personnel emoluments, administration, service, and investment).

- The extent to which government expenditures were allocated for poverty reduction programmes and projects.

\section{The Budget Preparation Process and Use of GPRS}

In the preparation of the 2004 Budget, several activities were undertaken to link the budget to the GPRS:

- Workshops were organised to improve MDAs understanding of the MTEP process as well as linking the GPRS and APR to the Budget;

- Within each priority area, MDAs were required to show the progress made in achieving targets set in the GPRS and the remaining gaps up to 2005;

- MDAs were required to incorporate poverty reduction policies of the GPRS into their Strategic Plans.

- The MDAs are reminded of the role of the GPRS and APR at the budget preparation stage and the inclusion of the GPRS programmes and projects in their budgets;

- The NDPC is represented at the budget preparation stage by the Director-General. $\mathrm{He} / \mathrm{She}$ ensures that the GPRS and the Annual Progress Report are considered in the budget preparation.

- The Annual Progress Report monitors the implementation of the GPRS. It is linked to the Budget through the policy initiatives recommended in the report which are meant to be implemented by the MDAs;

- In the 2004 Budget, resources allocated to the Social Sector were increased in response to recommendations from the APR to the extent that the GPRS target of 34.3\% in Social Sector allocation was increased to $38.8 \%$.

\section{The Macroeconomic Framework of 2004 Budget and the GPRS}

The 2004 Budget was driven by the underlying economic framework of the GPRS:

- increasing revenue intake to accommodate increased poverty-related spending and accelerated development; 
- strengthening public expenditure management; and

- using an optimum mix of appropriate fiscal and monetary policies to impact positively on macroeconomic targets including inflation.

The macroeconomic framework as provided in the budget is consistent with the GPRS targets (Table 2.1). The macroeconomic objectives and targets proposed in the 2004 budget are similar to those of the GPRS with only a few exceptions. Both the budget and the GPRS propose to tackle issues which include:

- Reduction of the domestic debt

- Reduction of inflation to single digits

- Increasing revenue mobilization

- Curtailing deficit financing by pursuing a policy of zero net domestic financing

- Rationalization of expenditure through effective monitoring

Table 2.1: Comparison of GPRS and 2004 Budget Macroeconomic Framework

\begin{tabular}{|l|c|c|c|c|}
\hline & $\begin{array}{c}\text { GPRS 2004 } \\
\text { targets }\end{array}$ & $\begin{array}{c}\text { BUDGET } \\
\mathbf{2 0 0 4}\end{array}$ & Status 2004 & $\begin{array}{c}\text { GPRS 2005 } \\
\text { targets }\end{array}$ \\
\hline Real GDP growth & & & & 5.0 \\
\hline Inflation & 5.0 & 5.2 & 5.8 & 6.0 \\
\hline Annual & & & & 5.0 \\
\hline End of period & 8.0 & Under 10\% & 12.6 & 3.1 \\
\hline Stock of reserves (months imports cover) & 7.0 & Under 10\% & 11.8 & 2.5 \\
\hline Domestic primary surplus as \% of GDP & 2.7 & 3 months & 3.8 & 0.6 \\
\hline Budget deficit as \% of GDP & 1.6 & 1.7 & 0.7 & 2.0 \\
\hline $\begin{array}{l}\text { Net domestic debt repayments as \% of } \\
\text { GDP }\end{array}$ & 2.4 & 2.2 & 3.2 & \\
\hline Sectoral growth & & & & 4.8 \\
\hline Agriculture & 5.8 & 6.0 & 7.5 & 5.2 \\
\hline $\begin{array}{l}\text { Industry } \\
\text { Services }\end{array}$ & 5.1 & 5.2 & 5.1 & 5.1 \\
\hline $\begin{array}{l}\text { Ratio of revenues (excluding grants) to } \\
\text { GDP }\end{array}$ & 22.5 & 22.5 & 23.8 & 2.3 \\
\hline
\end{tabular}

Source: MOFEP

- The GPRS target of 5\% GDP growth has been exceeded in 2004 with a growth rate of close to $6 \%$.

- Although inflation rates have fallen significantly since 2000 the 2004 single digit target has not been realised and is unlikely that the 2005 target of $5 \%$ can be achieved. This can be explained by the fact that the inflation target in an election year was too ambitious, there were higher than expected foreign inflows, an the economy was coming out of the effects of the 2003 petroleum price increases.

- Sectoral growth rates of output targeted by the GPRS have been achieved for 2004 and are likely to be exceeded in 2005 .

- Revenue targets have been achieved.

- Stock of reserves have improved and targets exceeded.

The objectives of the GPRS include:

- accelerated real GDP growth to $5 \%$ by 2005 ;

- reduction in poverty from $39 \%$ to $32 \%$;

- improvement in basic infrastructure such as roads, water, sanitation and market access;

- increase in the level of primary enrolment and education completion rates; 
- reduction in infant, child and maternal mortality and the incidence of infectious diseases;

- improvement in governance and the efficiency of the public sector.

- gender equity.

Five priority areas have been identified in the GPRS;

- Infrastructure Development

- Modernisation of Agriculture based on Rural development

- Enhanced Social Services

- Good Governance

- Private Sector Development

Table 2.2: Functional Distribution of Total Discretionary Expenditure: 2001-2004 (\%)

\begin{tabular}{|l|c|c|c|c|c|c|c|}
\hline & $\mathbf{2 0 0 1}$ & $\mathbf{2 0 0 2}$ & $\begin{array}{c}\text { GPRS } \\
\mathbf{2 0 0 3} \\
\text { Target }\end{array}$ & $\begin{array}{c}\mathbf{2 0 0 3} \\
\text { Budget }\end{array}$ & $\begin{array}{c}\text { GPRS } \\
\mathbf{2 0 0 4} \\
\text { Target }\end{array}$ & $\begin{array}{c}\text { Budget } \\
\mathbf{2 0 0 4}\end{array}$ & $\begin{array}{c}\text { GPRS } \\
\mathbf{2 0 0 5} \text { target }\end{array}$ \\
\hline Administration & $\mathbf{3 4 . 8 6}$ & $\mathbf{1 9 . 7 9}$ & $\mathbf{1 4 . 2}$ & $\mathbf{1 4 . 8 4}$ & $\mathbf{1 3 . 3}$ & $\mathbf{1 7 . 1}$ & $\mathbf{1 3 . 3}$ \\
\hline $\begin{array}{l}\text { Ministry of Local Government Rural } \\
\text { Development }\end{array}$ & 3.31 & 2.35 & & 2.75 & & 2.36 & \\
\hline Ministry of Finance & 2.20 & 3.15 & & 2.23 & & 2.15 & \\
\hline General Govt. Services & 21.19 & 5.07 & & & & & \\
\hline Economic & $\mathbf{1 4 . 9 9}$ & $\mathbf{1 8 . 0 2}$ & $\mathbf{9 . 7}$ & $\mathbf{9 . 0 6}$ & $\mathbf{1 0 . 3}$ & $\mathbf{8 . 9}$ & $\mathbf{1 0 . 3}$ \\
\hline Ministry of Food \& Agriculture & 7.17 & 4.69 & & 3.91 & & 3.03 & \\
\hline Infrastructure & $\mathbf{1 1 . 6 4}$ & $\mathbf{1 7 . 2 0}$ & $\mathbf{1 7 . 2}$ & $\mathbf{1 5 . 5 3}$ & $\mathbf{1 9 . 1}$ & $\mathbf{1 0 . 9}$ & $\mathbf{1 9 . 1}$ \\
\hline Social & $\mathbf{3 0 . 1 8}$ & $\mathbf{3 4 . 7 1}$ & $\mathbf{3 8 . 1}$ & $\mathbf{3 8 . 6 7}$ & $\mathbf{3 4 . 3}$ & $\mathbf{3 8 . 8}$ & $\mathbf{3 4 . 3}$ \\
\hline Ministry of Education ${ }^{1}$ & 22.44 & 24.14 & & 26.85 & & 26.65 & \\
\hline Ministry of Health & 6.67 & 9.38 & & 10.89 & & 11.15 & \\
\hline Public Safety & $\mathbf{7 . 9 4}$ & $\mathbf{9 . 6 7}$ & $\mathbf{1 1 . 1}$ & $\mathbf{1 1 . 5 2}$ & $\mathbf{9 . 0}$ & $\mathbf{1 1 . 9}$ & $\mathbf{9 . 0}$ \\
\hline Utilities & - & - & $\mathbf{2 . 7}$ & $\mathbf{2 . 6 9}$ & $\mathbf{3 . 2}$ & $\mathbf{2 . 5}$ & $\mathbf{3 . 2}$ \\
\hline Revenue Agencies & - & - & & $\mathbf{3 . 0 8}$ & & $\mathbf{3 . 0}$ & \\
\hline Contingency & $\mathbf{0 . 3 9}$ & $\mathbf{0 . 6 2}$ & $\mathbf{6 . 9}$ & $\mathbf{4 . 6 2}$ & $\mathbf{1 0 . 9}$ & $\mathbf{8 . 9}$ & $\mathbf{1 0 . 9}$ \\
\hline Grand Totals & $\mathbf{1 0 0}$ & $\mathbf{1 0 0}$ & $\mathbf{1 0 0}$ & $\mathbf{1 0 0}$ & $\mathbf{1 0 0}$ & $\mathbf{1 0 0}$ & $\mathbf{1 0 0}$ \\
\hline Total \&billion & & & & & & $\mathbf{1 3 , 0 0 5 . 3 7 8}$ & \\
\hline
\end{tabular}

Source: Appropriation Act and Budget Statements of 2001 to 2005

The 2004 budgetary targets and policy direction included major policy initiatives and financial provisions for the attainment of these goals.

The Budget's discussions of the performance of the various sectors of the economy in 2003 and the outlook for 2004 were conducted within the framework of the GPRS five priority areas. Provisions were made in the budget to fund these priority areas. (Appendix 8 of 2004 Budget Statement) There is a one-to-one link between budget expenditures and the MTP programmes and projects.

\subsection{DISCRETIONARY BUDGET FOR 2004 AND THE MEDIUM TERM PRIORITIES}

Table 2.2 shows the Functional Distribution of Total Discretionary Expenditure and Table 2.3 the distribution of total government discretionary expenditure for the 2001-2004 periods. 
In 2003 the link was obvious when the GPRS 2003 targets are compared with the 2003 budget. There is correspondence between the broad sectors especially for Administration and Economic and Social Sectors.

Budget allocations to the Social Service sector have increased consistently since the beginning of the implementation of the GPRS. In 2003 and 2004 allocations to the sector exceeded the GPRS targets. The 2004 spending reported by CAGD (Table 2.3B) indicates that GoG spending in the Social Sector of $55.1 \%$ of MDAs discretionary spending exceeded the budget target of $48.1 \%$. Additional funds constituting $28.5 \%$ of HIPC funds were also spent on the sector

Table 2.3A: Functional Distribution of Total GOG Expenditure 2001-2004 (\%)

\begin{tabular}{|c|c|c|c|c|}
\hline & 2001 & 2002 & 2003 & $\begin{array}{c}2004 \\
\text { Budget }\end{array}$ \\
\hline Administration & 41.5 & 25.8 & 16.4 & 18.2 \\
\hline $\begin{array}{l}\text { Ministry of Local Government Rural } \\
\text { Development }\end{array}$ & 2.4 & 1.7 & 1.8 & 1.63 \\
\hline Ministry of Finance & 2.9 & 4.0 & 1.9 & 1.69 \\
\hline General Govt. Services & 27.8 & 8.3 & 0 & \\
\hline Economic & 5.3 & 6.8 & 5.4 & 5.3 \\
\hline Ministry of Food \& Agriculture & 1.4 & 2.3 & 1.7 & 1.36 \\
\hline Infrastructure & 4.4 & 3.7 & 3.8 & 4.6 \\
\hline Social & 37.2 & 47.4 & 45.8 & 42.7 \\
\hline Ministry of Education ${ }^{1}$ & 28.4 & 35.3 & 33.4 & 31.69 \\
\hline Ministry of Health & 0.0 & 10.3 & 11.2 & 9.77 \\
\hline Public Safety & 11.0 & 15.3 & 14.8 & 14.3 \\
\hline Utilities & - & - & 3.6 & 3.0 \\
\hline Revenue Agencies & - & - & 4.1 & 3.7 \\
\hline Contingency & 0.5 & 1.0 & 6.1 & 8.3 \\
\hline Grand Totals & 100 & 100 & 100 & 100 \\
\hline
\end{tabular}

Source: Computed from Appropriation Act and Budget Statements of 2001 to 2005

This consistent increase of resources to the Social Services sector translates into an increase in resources to activities directed to the poor, vulnerable and excluded reflecting the broad priorities of the GPRS. Within the sector there was a switch in resources to the Health subsector at the expense of education. Allocation to education in 2004 was slightly below that of 2003. The increase was in response to the recommendations of the 2003 APR.

Economic Services sector's allocation has declined since 2002 declining by almost 50 percent from $18.02 \%$ to $8.9 \%$ which is below the GPRS target of $10.3 \%$. Allocations to the agriculture sub-sector continued to decline. From $7.1 \%$ in 2001, it has declined to $3.03 \%$ in 2004 . This decline in the agricultural sector's share has serious implications for the poor to the extent that the poor relies on agriculture and related activities.

Infrastructure's share has been below the GPRS targets. The allocation of $10.93 \%$ in 2004 was below the GPRS targets of $19.1 \%$, although some HIPC funds (15.5\%) were spent on the sector.

The Public Safety sector has been receiving increased allocation reflecting the importance of upholding the rule of law, public order and safety as major pillars of the GPRS with a slight increase in 2004 to $11.9 \%$ from the 2003 allocation of $11.52 \%$ and $4.3 \%$ of HIPC funds. 
It must be noted that increased allocation to Social Services to provide relief and safety nets to the poor and vulnerable has crowded out resources to the economic services sector which supports wealth creation and sustained poverty reduction. There is a trade-off between wealth creation through augmenting the resources to agriculture and economic sectors to enhance growth and sustain poverty reduction and providing social services and relief to the poor.

Table 2.3B: Budgetary and Actual GOG and HIPC* Spending 2004

\begin{tabular}{|c|c|c|c|c|}
\hline & Budget & GoG Spending & $\begin{array}{c}\text { HIPC } \\
\text { Transfer }\end{array}$ & $\begin{array}{c}\text { HIPC } \\
\text { Transfers }\end{array}$ \\
\hline & $\%$ & $\%$ & cbillion & $\%$ \\
\hline Administration & 24.7 & 21.7 & 501.329 & 33.1 \\
\hline Ministry of Local Government & 1.8 & 1.8 & 294.727 & 19.4 \\
\hline Ministry of Finance & 6.1 & 6.1 & 54.612 & 3.6 \\
\hline Electoral Commission & 2.2 & 0.9 & 5.384 & 0.4 \\
\hline Economic Services & 6.2 & 5.4 & 282.251 & 18.6 \\
\hline Ministry of Agriculture & 1.5 & 1.4 & 24.229 & 1.6 \\
\hline Infrastructure & 4.9 & 4.1 & 235.143 & 15.5 \\
\hline Social Services & 48.1 & 55.1 & 432.016 & 28.5 \\
\hline Ministry of Education & 35.3 & 41.0 & 287.809 & 19.0 \\
\hline Ministry of Health & 11.0 & 14.1 & 110.926 & 7.3 \\
\hline Public safety & 16.1 & 13.8 & 64.713 & 4.3 \\
\hline Total percentage & 100 & 100 & & 100 \\
\hline Total billions of cedis & 9,317 & 9,646 & $1,515.461$ & \\
\hline
\end{tabular}

Source: Controller and Accountant General's Department

* This excludes payment of domestic debt of $₫ 301.4$ billion

Table 2.4: Expenditures in Priority Areas as \% of Total Expenditure

\begin{tabular}{|l|c|c|c|c|}
\hline & $\mathbf{2 0 0 1}$ & $\mathbf{2 0 0 2}$ & $\mathbf{2 0 0 3}$ & 2004 Budget \\
\hline Economic services & 14.99 & 18.02 & 9.06 & 8.92 \\
\hline Social Services & 30.18 & 34.71 & 38.67 & 38.82 \\
\hline Infrastructure & 11.64 & 17.20 & 15.33 & 10.93 \\
\hline Public Safety & 7.94 & 9.67 & 11.53 & 11.67 \\
\hline TOTAL & 64.75 & 79.6 & 74.78 & 70.5 \\
\hline
\end{tabular}

Source: Computed from Table 1.4

Expenditures on the priority sectors as indicated in Table 3.4 declined from about $74.8 \%$ in 2003 to $70.45 \%$ in 2004 . This could be attributed to the increasing share of Contingency item from $0.39 \%$ in 2001 to $7.08 \%$ in 2004 ; this is meant to serve as a cushion to possible shocks.

\section{Government Spending on Poverty Reduction}

Poverty reduction requires infusion of resources not only to the broad priority sectors, but also to programmes and projects in the areas known to be poor. The 2004 Budget had a strong linkage with the GPRS. Table 3.5 shows GOG poverty related expenditures in by sector in 2004 . In spite of the financial constraints, poverty related activities were funded in full. Government addressed poverty by increasing its share of spending in the social sector and through direct actions to increase productive assets and basic services to the poor by spending 6441.39 billion cedis in 2004. Poverty reduction spending was in effect increased by $43.1 \%$ in 2004 over 2003 significantly greater than the planned 34.4\% increase over 2003.

Expenditures on poverty reduction constituted about $28.1 \%$ of total government spending in 2004 and slightly exceeded planned expenditures of $27.97 \%$ for the year. Poverty related expenditures were largely directed at Basic Education, Primary Health Care, Agriculture, Rural water, Feeder Roads and Rural Electrification. The slight decline in the share of spending on primary health care can be explained by the increase in "other poverty" expenditure. 
The pro-poor spending was supported by allocation of HIPC funds to the following priority areas of the GPRS:

- macroeconomic stability - $\not 301.4$ billion was used for domestic debt servicing;

- human resource development - $\$ 393.62$ billion was released for various educational programmes and activities; $\notin 178$ billion for the health sector and $\notin 179$ billion for the provision, and $₫ 79$ billion for water and sanitation;

- private sector development - $₫ 677$ billion was disbursed for activities in agriculture and infrastructure;

- modernization of agriculture - $\notin 72$ billion;

- energy sector - SHEP was funded with about $₫ 228$ billion;

- good governance - $\not 125$ billion was disbursed for the 2004 elections.

Table 2.5: Government Spending on Poverty Reduction

\begin{tabular}{|c|c|c|c|c|}
\hline & 2003 Budget & 2003 Actual & 2004 Budget & 2004 Actual \\
\hline Total poverty reduction exp. $<$ billion & 4059.28 & 4278.74 & 5456.21 & 6122.61 \\
\hline Total govt expenditure $\phi$ billion & 15713 & 15744.10 & 19507.80 & 21765.10 \\
\hline Total poverty red. exp. as $\%$ of total Govt exp. & 25.83 & 27.18 & 27.97 & 28.13 \\
\hline \multicolumn{5}{|l|}{ BASIC EDUCATION } \\
\hline Basic education exp. cbillion & 1911.28 & 2356.52 & 2605.37 & 2969.76 \\
\hline Education Expenditure cbillion & 3300.59 & 4049.13 & 4512.65 & 5289.76 \\
\hline Basic education as $\%$ of Education. Exp & 57.91 & 58.20 & 57.73 & 56.15 \\
\hline$\%$ of Total Poverty Spending & 47.1 & 55.07 & 47.75 & 48.50 \\
\hline \multicolumn{5}{|l|}{ PRIMARY HEALTH CARE } \\
\hline Primary Health Care exp. $\quad$ cbillion & 826.20 & 633.54 & 1205.32 & 1088.20 \\
\hline Health sector exp. $\quad$ billion & 1124.95 & 1061.21 & 1550.92 & 1622.02 \\
\hline PHC as $\%$ of Health Sec exp & 73.44 & 59.70 & 77.72 & 67.09 \\
\hline$\%$ of Total Poverty Spending & 20.3 & 18.81 & 22.09 & 17.77 \\
\hline \multicolumn{5}{|l|}{ POVERTY FOCUSED AGRIC } \\
\hline Poverty Focused Agric Exp cbillion & 141.89 & 109.51 & 132.68 & 145.05 \\
\hline Agric. Sector Exp. ebillion & 157.40 & 114.27 & 146.91 & 150.34 \\
\hline Poverty Agric. as $\%$ of Sector Exp. & 90.15 & 95.83 & 90.31 & 96.48 \\
\hline$\%$ of Poverty Spending & 3.5 & 2.56 & 2.4 & 2.4 \\
\hline \multicolumn{5}{|l|}{ RURAL WATER } \\
\hline Rural Water Exp. cbillion & 108.86 & 41.42 & 140.86 & 111.99 \\
\hline Works \& Housing exp. ebillion & 156.98 & 89.95 & 225.11 & 228.64 \\
\hline $\begin{array}{l}\text { Rural Water Exp as \% of Works and Housing } \\
\text { Exp. }\end{array}$ & 64.41 & 46.05 & 62.57 & 48.98 \\
\hline$\%$ of Poverty Spending & 2.7 & 1.0 & 2.6 & 1.8 \\
\hline \multicolumn{5}{|l|}{ FEEDER ROADS } \\
\hline Feeder Roads exp cbillion & 227.98 & 306.38 & 296.52 & 337.98 \\
\hline Roads and Transport exp $\notin$ billion & 887.38 & 809.28 & 1039.69 & 1045.32 \\
\hline $\begin{array}{l}\text { Feeder Roads Exp as \% of Roads and } \\
\text { Transport exp }\end{array}$ & 25.69 & 37.86 & 28.52 & 32.33 \\
\hline$\%$ of Poverty Spending & 5.6 & 7.2 & 5.4 & 5.5 \\
\hline \multicolumn{5}{|l|}{ RURAL ELECTRIFICATION } \\
\hline Rural elect. Exp. cbillion & 91.93 & 58.21 & 156.15 & 187.81 \\
\hline Energy sector exp. $\notin$ billion & 111.0 & 69.21 & 193.8 & 216.39 \\
\hline Rural electrification as \% of Energy sector exp. & 82.82 & 83.98 & 80.57 & 86.79 \\
\hline$\%$ of Poverty Spending & 2.3 & 1.4 & 2.9 & 3.1 \\
\hline
\end{tabular}




\begin{tabular}{|l|l|l|l|l|}
\hline OTHER POVERTY EXPENDITURES* & & & & \\
\hline Other Poverty exp. cbillion & 751.04 & 773.16 & 919.31 & 1281.82 \\
\hline Other poverty exp. as \% of Tot Govt exp. & 4.78 & 4.91 & 4.71 & 5.89 \\
\hline$\%$ of Poverty Spending & 18.6 & 18.1 & 16.8 & 20.9 \\
\hline
\end{tabular}

Source: 2003, 2004, 2005 Budget Statements and Ministry of Finance and Economic Planning.

* Other poverty expenditures include: Social welfare, Governance, Drainage, Human rights, Public Safety, HIV/AIDS, Vocational/Employable Skills, Road Safety, Environmental Protection and disaster management

\subsection{DONOR RESOURCES AND GPRS PRIORITIES}

As shown in Table 2.6 donor resources to sectors of the economy in 2003 were in broad conformity with the Medium Term Priorities of the GPRS. There was a significant increase in allocation to Administration higher than in 2002 and 2003 reversing the downward trend since 2001.The Ministry of Finance also experienced a little increase. But it was the Ministry of Health which was a significant beneficiary of donor expenditure, improving on the increase from $8.0 \%$ in 2002 to $9.9 \%$ in 2003 to $15.44 \%$ in 2004 . Infrastructure which is the largest recipient of donor allocations experienced a decline from $51.5 \%$ to $43.49 \%$. An important aspect of donor funding was the unexpected increase in actual expenditure to $\Varangle 5.8$ trillion which is more than double the budget target for 2004 of $\$ 2.492$ trillion

Allocations to the Public Safety sector by donors declined from $1.6 \%$ to only $1.52 \%$ in 2004 .

Table 2.6: Functional Distribution of Total Donor Spending: 2001-04

\begin{tabular}{|c|c|c|c|c|}
\hline & 2001 & 2002 & 2003 & $\begin{array}{c}2004 \\
\text { Budget }\end{array}$ \\
\hline Administration & 17.5 & 10.4 & 9.9 & 12.8 \\
\hline Ministry of Local Government Rural Development & 5.7 & 3.4 & 5.5 & 5.40 \\
\hline Ministry of Finance & 0.5 & 1.8 & 3.3 & 4.10 \\
\hline General Govt. Services & 3.8 & 0.0 & 0.0 & 0.0 \\
\hline Economic & 40.2 & 35.4 & 20.3 & 24.3 \\
\hline Ministry of Food \& Agriculture & 22.3 & 8.5 & 10.7 & 10.10 \\
\hline Infrastructure & 30.5 & 38.2 & 51.5 & 37.8 \\
\hline Social Services & 11.8 & 15.0 & 16.7 & 22.6 \\
\hline Ministry of Education & 6.9 & 6.8 & 6.7 & 5.38 \\
\hline Ministry of Health & 4.9 & 8.0 & 9.9 & 16.93 \\
\hline Public Safety & 0.0 & 1.0 & 1.6 & 1.5 \\
\hline Utilities & - & - & - & - \\
\hline Revenue Agencies & - & - & - & - \\
\hline Contingency & - & - & - & 1.0 \\
\hline Grand Totals & 100 & 100 & 100 & 100 \\
\hline cbillion & & & & $2,492,200$ \\
\hline
\end{tabular}

Source: computed from Appropriation Acts 2001-2004

\section{Utilisation of Discretionary Payments}

Table 2.7 shows that although the sectoral allocations may broadly reflect GPRS priorities, personnel emoluments are still the largest component of discretionary expenditures. Its share of total discretionary payments from $43.7 \%$ in 2003 to $35.1 \%$ in 2004 , although as a percent of GDP personal emoluments increased over the period. Allocation to Administration also increased as a percentage of GDP implying that these expenditures are growing faster than the growth in GDP. 
A significant amount of funds which could have been used to improve investments were directed to financing the large increase in utility price subsidies which shot up from 2.15 in 2003 to $11.2 \%$ in 2004 .

Investment allocation increased from $27.8 \%$ to $29.4 \%$, the increase being mainly attributed to increased donor funding, although there was a little increase in domestic financed investment. The ratio of domestic financed investments to total investments in 2004 was $26.2 \%$, with the rest being foreign financed. Although the dependence on donor funds has declined, it still accounts for a greater part of the nation's investment expenditure thus rendering development efforts extremely susceptible to the vagaries of donor resource flows. To avoid the possibility of development agenda being susceptible to resource inflows, the Multi Donor Budget Support (MDBS) needs to be strengthened and more donors encouraged to join.

Table 2.7: Utilization of Discretionary Payments $\not b i l l i o n$

\begin{tabular}{|c|c|c|c|c|c|c|c|}
\hline & 2002 & 2003 & 2003 & 2003 & $\begin{array}{c}2004 \\
\text { planned }\end{array}$ & $\begin{array}{c}2004 \\
\text { actual }\end{array}$ & $\begin{array}{c}2004 \\
\text { actual }\end{array}$ \\
\hline ITEM & cbillion & ebillion & $\begin{array}{c}\% \text { of total } \\
\text { exp. }\end{array}$ & $\begin{array}{l}\% \text { of } \\
\text { GDP }\end{array}$ & $\begin{array}{c}\% \text { of total } \\
\text { exp. }\end{array}$ & $\begin{array}{c}\% \text { of total } \\
\text { exp. }\end{array}$ & $\begin{array}{l}\% \text { of } \\
\text { GDP }\end{array}$ \\
\hline Personnel Emoluments & $4,197.1$ & $5,661.3$ & 43.7 & 8.55 & 44.3 & 35.1 & 8.7 \\
\hline $\begin{array}{l}\text { Administration and } \\
\text { Service }\end{array}$ & $1,452.4$ & $1,762.9$ & 13.6 & 2.7 & 18.2 & 11.9 & 3.0 \\
\hline Service & 372.7 & 662.7 & 5.1 & 5.1 & 7.8 & 4.7 & \\
\hline Investment & $1,951.2$ & $3,600.7$ & 27.8 & 5.4 & 24.9 & 29.4 & 7.3 \\
\hline Domestic financed & 299.6 & 524.9 & 4.0 & 0.8 & 8.2 & 6.1 & 1.5 \\
\hline Foreign financed & $1,651.5$ & $3,075.7$ & 23.7 & 4.6 & 16.6 & 23.3 & 5.8 \\
\hline Utility price subsidies & 449.9 & 272.5 & 2.1 & 0.4 & 0.6 & 11.2 & 2.8 \\
\hline $\begin{array}{l}\text { HIPC financed } \\
\text { Expenditure }\end{array}$ & 175.1 & 866.3 & 6.7 & 1.3 & 8.1 & 9.5 & 2.3 \\
\hline Others & 545.3 & 797.3 & 6.1 & 1.2 & & & \\
\hline Total & & & 100 & 100 & & & 100 \\
\hline (cbillion) & 8,771 & 12,961 & & & $14,982.6$ & $19,773.2$ & \\
\hline
\end{tabular}

Source: 2004, 2005 Budget, Appendix Tables

The Government needs to maintain an appropriate balance between expenditures on overheads (i.e. personnel emoluments and administrative expenses) on the one hand and expenditures on services and investments on the other.

Table 2.8 shows investment spending in each sector as a percentage of the sectors' Discretionary Expenditure in 2004. Within each sector investment spending by government constitute a small proportion of the sector's spending with the remaining spent on emoluments, administration and services. It is only in infrastructure $(68.2 \%)$ that a large percentage of the spending is for investment. On the contrary, donor funding is mainly for investment, with for example $96.8 \%$ and $73.5 \%$ of donor funding in infrastructure and administration respectively being for investments. 
Table 2.8: Investments as a percentage of Sector Discretionary Expenditure in 2004

\begin{tabular}{|l|c|c|}
\hline & $\begin{array}{c}\text { GoG investments planned } \\
2004\end{array}$ & $\begin{array}{c}\text { Donor investments } \\
\text { Planned 2004 }\end{array}$ \\
\hline Administration & 14.6 & 73.5 \\
\hline Local Government & 9.8 & 95.3 \\
\hline Finance & 15.0 & 69.9 \\
\hline Economic & 17.19 & 51.9 \\
\hline Ministry of Food \& Agriculture & 12.7 & 41.7 \\
\hline Infrastructure & 68.2 & 96.8 \\
\hline Social & 2.2 & 33.7 \\
\hline Education & 1.8 & 62.8 \\
\hline Health & 2.4 & 23.7 \\
\hline Public safety & 5.41 & - \\
\hline Utilities & - & - \\
\hline Revenue Agencies & 19.4 & - \\
\hline Contingencies & 21.2 & 100 \\
\hline
\end{tabular}

Source: Computed from 2004 Budget Statement, Appendix Tables

\subsection{ACHIEVEMENTS OF 2004 BUDGET INITIATIVES}

Table 2.9 summarises the achievements of the 2004 Budget initiatives, and assesses whether these initiatives were implemented.

Table 2.9: 2004 Budget Initiatives and Achievements

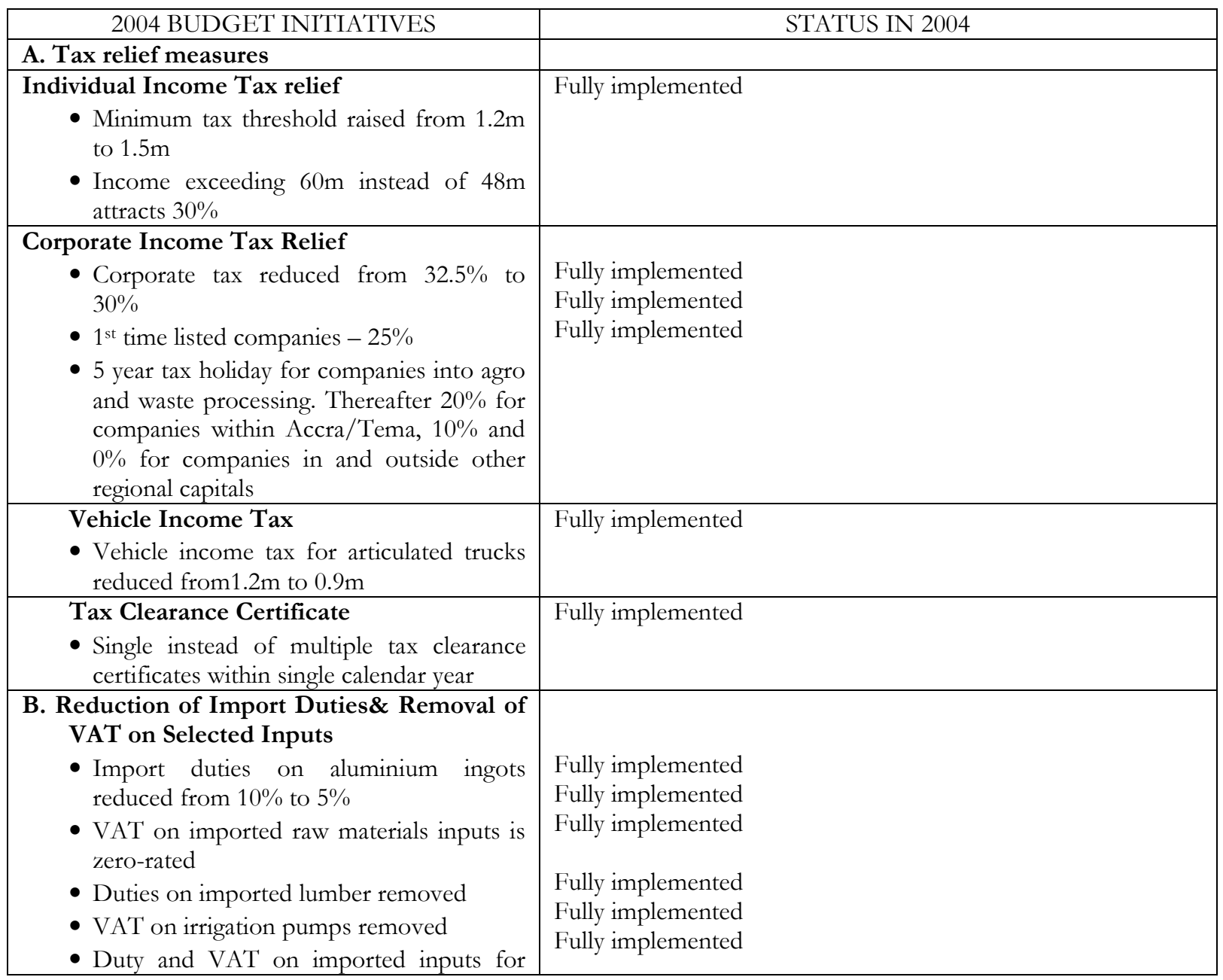




\begin{tabular}{|c|c|}
\hline $\begin{array}{l}\text { fishing nets and ropes removed } \\
\text { - Taxes on musical instruments removed } \\
\text { - GCNET processing fee on currency } \\
\text { importation removed }\end{array}$ & $\begin{array}{l}\text { Fully implemented } \\
\text { Fully implemented }\end{array}$ \\
\hline $\begin{array}{l}\text { Automation } \\
\text { - GCMS to be deployed to Aflao and Elubo } \\
\text { by } 1^{\text {st }} \text { Quarter } 2004 \\
\text { - DVLA to be connected to the GCNET to } \\
\text { reduce illegal vehicle clearance and } \\
\text { registration } \\
\text { Non-Tax Revenue } \\
\text { - Ensure competitive returns / dividends } \\
\text { from government's investments } \\
\text { - Ensure proper disclosure and } \\
\text { accountability on the retained and use of } \\
\text { non-tax revenue by authorized MDAs } \\
\text { - Interest Rates computation on } \\
\text { government contracts be reviewed } \\
\text { - Low cost houses nationwide should be } \\
\text { sold to occupiers and other prospective } \\
\text { buyers and proceed invested into the } \\
\text { Rural Housing program } \\
\text { - Restructuring of GCB - Government } \\
\text { decision on its shareholding }\end{array}$ & $\begin{array}{l}\text { Aflao operational, Elubo to be operational in March } 2005 \\
\text { Network exists } \\
\text { Partially implemented } \\
\text { - Non-Tax receipts of } \notin 1,136.3 \text { billion exceeded the } \\
\text { budgeted estimates by nearly } 68 \text { percent, mainly as a result } \\
\text { of more effective implementation of the Financial } \\
\text { Administration Act as it relates to State Owned Enterprises } \\
\text { (SOEs). The } 2004 \text { performance represented } 1.4 \text { percent of } \\
\text { GDP compared to } 0.5 \text { percent of GDP in } 2003 \text {. } \\
\text { Embarking on an exercise with the Security Agencies to } \\
\text { track illegal operators (in } 10 \text { MDAs) behind forgery and } \\
\text { duplication of Value Books to curtail revenue leakages. } \\
\text { Twenty five ( } 25 \text { ) illegal operators have so far been } \\
\text { prosecuted; } \\
\text { Release of } \notin 11.5 \text { billion to } 18 \text { MDAs to implement } \\
\text { revenue enhancement measures; }\end{array}$ \\
\hline $\begin{array}{l}\text { D. Consumer protection Through } \\
\text { Enforcement of Health and Safety } \\
\text { Standards } \\
\text { - Food \& Drug Board to be resourced to } \\
\text { ensure that all food items, drugs, } \\
\text { cosmetics, medical devices and household } \\
\text { chemicals both of local and foreign origins } \\
\text { meet all prescribed health, quality and } \\
\text { safety standards. } \\
\text { - Enhance value addition in Cocoa Industry } \\
\text { by increasing local processing of raw } \\
\text { cocoa beans from the current } 25 \% \text { to } 35 \% \\
\text { - Extend 5-year tax holiday to companies } \\
\text { that use cocoa waste as their main or } \\
\text { principal raw materials. } \\
\text { - New varieties of pineapple to be } \\
\text { introduced } \\
\text { - Regulated warehouse receipt system for } \\
\text { agricultural commodities to be developed } \\
\text { to assure price stability and sustainable } \\
\text { provision of finance to farmers. }\end{array}$ & Implemented \\
\hline $\begin{array}{l}\text { E. Financial Sector Reforms } \\
\text { - Introduce the Long-Term Savings Bill and } \\
\text { provide selected tax relief under the Long } \\
\text { term saving Scheme } \\
\text { - Other Bills to be introduced: } \\
\text { - Foreign Exchange Bill } \\
\text { - Credit Union Bill } \\
\text { - The Insurance Bill } \\
\text { - Bills and Cheques Bill to reform the Bill of } \\
\text { - Exchange Act } \\
\text { - Implement the Venture Capital Fund } \\
\text { - Government Support to Eximguaranty }\end{array}$ & $\begin{array}{l}\text { - The Venture Capital Fund Bill and the Long Term Savings } \\
\text { Bill were both passed by Parliament. The Venture Capital } \\
\text { Fund is to address inadequate capital problems of the } \\
\text { private sector especially, the Micro, Small and Medium } \\
\text { Enterprises (MSME); while the Long Term Savings law is } \\
\text { to deepen savings mobilisation for the economy as well as } \\
\text { to broaden retirement options for Ghanaian workers; } \\
\text { - In 2005, The Government will actualize the take-off of } \\
\text { both the Venture Capital Trust Fund and Long Terms } \\
\text { Savings Scheme. Supplementary laws to strengthen } \\
\text { Payment Systems, namely Foreign Exchange Bills and } \\
\text { Cheque Bill will be tabled before Parliament } \\
\text { The Ministry of Finance will pursue the passage of ancillary }\end{array}$ \\
\hline
\end{tabular}




\begin{tabular}{|c|c|}
\hline $\begin{array}{l}\text { Company Ltd } \\
\text { - Government Support in the Micro \& } \\
\text { Small Enterprises Sector - Restructuring } \\
\text { of Government sponsored Micro Finance } \\
\text { Programs }\end{array}$ & $\begin{array}{l}\text { regulatory laws such as Credit Bureau Law, Non-Bank } \\
\text { Financial Institutions Law and Money Laundering/CFT } \\
\text { Law. Similarly, the Insurance Law to enable insurance } \\
\text { business enhance its savings mobilization role and further } \\
\text { create level playing field within the Insurance Industry will } \\
\text { also be tabled before Parliament. } \\
\text { Government will submit to parliament a number of } \\
\text { legislations in } 2005 \text { including the Foreign Exchange Bill, } \\
\text { the Anti-Money Laundering Bill, Credit Union Bill and the } \\
\text { Non-Bank Financial Institutions Bill for passage into law. }\end{array}$ \\
\hline $\begin{array}{l}\text { F. Public Sector Reform } \\
\text { - Finalise and implement the first phase } \\
\text { of the reform with emphasis on } \\
\text { participation and ownership by public } \\
\text { servants and their respective Ministers. }\end{array}$ & $\begin{array}{l}\text { The office pursued the additional responsibility for } \\
\text { Public Sector Reform (PSR), where it took a critical look } \\
\text { at the gamut of programmes being pursued with the aim } \\
\text { of giving a new image and direction for PSR. The office } \\
\text { developed a framework that would enable it re-examine } \\
\text { and make proposals for retooling the Public Sector. A } \\
\text { draft proposal on the way forward has received Cabinet } \\
\text { approval. Some institutions involved in the } \\
\text { implementation aspects of the PSR, have their objectives } \\
\text { and aims redefined to conform to the new proposals and } \\
\text { vision. }\end{array}$ \\
\hline $\begin{array}{l}\text { G. Deregulation in the Petroleum Industry } \\
\text { - Accelerate the program for deregulation } \\
\text { of petroleum sector approved by } \\
\text { Cabinet }\end{array}$ & $\begin{array}{l}\text { Preparatory works for the commencement of the deregulation } \\
\text { programme in } 2005 \text { were carried out in } 2004 \text {. } \\
\text { - As a first step, Tema Oil Refinery's (TOR) } \\
\text { operations were restricted to processing of crude oil in } \\
2004 \text { and the private sector (Oil Marketing Companies } \\
\text { (OMCs)) agreed to finance the procurement and } \\
\text { importation of the shortfall of finished products. The first } \\
\text { tender for importation was held in March, 2004. } \\
\text { - The following projects were also undertaken in order } \\
\text { to ensure availability of petroleum products in all parts of } \\
\text { the country and also for export: Rural Kerosene } \\
\text { Distribution Improvement Programme; Export Oriented } \\
\text { Oil Refinery Project; Single Buoy Mooring (SBM) Project; } \\
\text { and Buipe-Bolgatanga Petroleum Products Pipeline } \\
\text { Project. } \\
\text { Began in March with limited importation of crude oil } \\
\text { by Oil Marketing Companies }\end{array}$ \\
\hline
\end{tabular}

\subsection{POLICY RECOMMENDATIONS}

- So far there is no gender specific budgeting and the little allocation to the Ministry of women and Children's affairs is getting even smaller. This could be attributed to the limited experience with gender specific budgeting. The role of the Ministry of Finance and Economic Planning in this will be strengthened.

- The MTEF process needs to be strengthened, a necessary requirement for linking medium term policy planning and the budget.

- In the preparation of the 2006 Budget the link between the Budget and the Annual Progress Report will be further strengthened. This will be achieved through the circulation of the policy initiatives recommended in the 2004 APR to the Chief Directors and the PPMEs of the MDAs These policy initiatives need to be known well in advance by the MDAs so that they can be budgeted for. 


\section{CHAPTER THREE}

\section{OVERVIEW OF THE FINANCIAL PERFORMANCE OF DISTRICT ASSEMBLIES}

This section examines the performance of districts with regard to major sources of funding. It includes a review of DACF, HIPC fund, and Internally Generated Funds and how these were utilised.

\subsection{SOURCES OF FUNDS TO DISTRICTS}

Funding for the execution of district development plans come from a wide number of sources. The major established sources however remain:

* GoG subvention to districts for salaries and other administrative expenditure

* District Assemblies' Common Fund, (DACF)

* GOG funds through MDAs

* HIPC relief fund

* Development Partners: (EU, CIDA, DANIDA, UNICEF, GTZ/KfW, AFD, DFID, JICA, USAID, WB, etc.)

* Internally generated revenue of the Districts

* NGOs (WVI, ADRA, CLIP SFL, ... etc.)

\subsection{GATHERING OF DATA}

Data for assessing the relative strengths of all the sources of funds to the Districts are not readily available and not easy to disaggregate from financial returns submitted by the districts. However, data for analysing DACF has been obtained principally from the DACF Administrator's Office, the MLGRD and from the districts. Data on the internal revenue generated by districts has been obtained from the MLGRD while information on allocations from the HIPC Fund to MDAs and districts has been supplied by the Controller \& Accountant General's Department, CAGD. Other data and information for this part of the APR has been gathered from RPCUs and the DPCUs.

The institutional arrangements between the NDPC, the RCCs/RPCUs and the District Assemblies / DPCUs for monitoring are still weak. Regional Poverty Monitoring Groups (RPMG) were inaugurated in 8 regions in 2004. The RPMG were assigned roles including that of establishing District Poverty Monitoring Groups but due to the lack of resources RPMGs have not been functioning. This makes the collection of data from the regions and districts difficult and not harmonised. When RPCUs and their Regional Poverty Monitoring Groups are performing their roles effectively, they should routinely forward data and information to the NDPC and not have to be requested to do so; DPCU/ District Poverty Monitoring Groups in turn should routinely supply information and data to the RPCU.

However in the year 2004, a significant and commendable step was achieved with regard to decentralised M\&E in the Upper East region. The RPCU together with all six districts in the region and technical support from a development partner completed Monitoring Designs for their District Medium Term Development Plans (DMTDP) which are based on the thematic areas of the national GPRS. The implementation of GPRS /DMTDPs will be more effective when everyone knows what objectives have been agreed on and what indicators will be used to measure progress. The monitoring plans were therefore designed based on each district's 
DMTDP. Each district held consultations with stakeholders in order to arrive at objectively verifiable indicators for the district. These individual district monitoring plans were collated at the RPCU and published into a booklet as a practical guide for easy reference.

The Designing of the Monitoring plans in the Upper East Region is an example of what is workable and what therefore the MLGRD should look for and put in the necessary policy and make resources available for other RPCUs to design monitoring plans.

\subsection{COMPOSITE BUDGETING}

Since the inception of District Assemblies, planning of district development has been decentralised with each district autonomously drawing up Medium Term Development Plans. The Local Government Act, 1993, (Act 462) and the Local Government Service Act, 2004 (Act 656) with Legislative Instruments, all serve to deepen decentralisation and to ensure that authority, power and functions have been devolved to DAs. However financial resources have not been fully decentralised; with some decentralised departments still holding on to their budgets at the centre.

As a result therefore, the MLGRD started to pilot Composite Budgeting in three districts in 2004 and the programme is to be extended to 22 more districts in the current year. All 138 District Assemblies are to be operating with composite budgets by the year 2007 . Under this programme, decentralised departments are to submit their budget proposals to be harmonised into the District Assemblies' budget.

\subsection{THE DISTRICT ASSEMBLIES' COMMON FUND (DACF)}

The DACF (a portion of total national revenue allocated to districts) was to be increased from $5 \%$ to $7.5 \%$ in 2004 . This has not been implemented and with the 2005 budget already under way it is not likely that this policy will take effect in 2005.

The Administration of the DACF continues to be guided by an approved sharing formula; utilisation by the districts is also by guidelines approved in 2003. Districts actually receive $90 \%$ of their allocations the remaining $10 \%$ is kept in a reserve fund. The Reserve fund is utilised as follows:

- $5 \%$ is shared among parliamentary constituencies for use by MPs

- RCCs are allocated 2.5\%;

- The DACF office is allocated $0.5 \%$ for its field operations and

- $2 \%$ is kept as contingency

A summary of the guidelines issued to districts on how to apply the DACF is given below (these percentages refer to $90 \%$ of the district's share). A review of the guidelines is in progress and new guidelines for the utilisation of the DACF are due to be issued in 2005. 
Table 3.1 Guidelines for the Use of the DACF 2002-2004

\begin{tabular}{|l|l|c|}
\hline & Activity & $\begin{array}{c}\text { Percentage of } \\
\text { DACF to be used }\end{array}$ \\
\hline A & Capacity \& Human Resource Improvement & $2 \%$ \\
\hline B & $\begin{array}{l}\text { Productivity Improvement \& Employment Generation [popularly called Poverty } \\
\text { Alleviation Fund] given as micro-credit }\end{array}$ & $20 \%$ \\
\hline C & Support for Self Help projects initiated by communities & $10 \%$ \\
\hline D & District Education Fund to support scholarships / and needy students & $2 \%$ \\
\hline E & Establishing and strengthening of sub-district structures & $5 \%$ \\
\hline F & District Response Initiative (DRI) on HIV/AIDS & $1 \%$ \\
\hline G & Malaria Control & $1 \%$ \\
\hline H & $\begin{array}{l}\text { Other economic, social, environmental, administrative programmes and projects in the } \\
\text { districts budget and development plans }\end{array}$ & $59 \%$ \\
\hline & \multicolumn{1}{|c|}{ Total } & $\mathbf{1 0 0 \%}$ \\
\hline
\end{tabular}

Source: DACF Administrator's Office

\subsection{DACF RELEASES FOR 2004}

Lodgements into the District Assemblies Common Fund (DACF) improved tremendously in 2004, with the payment of all four quarterly releases and the payment of two instalments of arrears. Thus disbursements from the fund to DAs which was characterised by delays and arrears, is now timely and all arrears dating back many years will soon be cleared.

Disbursements by the Administrator to districts amounted to $₫ 857.172$ billion in the year. This consisted of four quarterly releases to Metropolitan, Municipal and District Assemblies amounting to $\notin 771,454,800,000$. The balance of $\notin 85,717,200,000$ went to the MPs Fund, the Reserve fund, and for Administration. The Regional Coordinating Councils (RCCs) received $\$ 21.43$ billion of the DACF for monitoring the progress of districts in their regions. Analysis of regional totals shows that there is some consistency in the proportions of DACF being disbursed from the 2003 and 2004 figures. Details of these are contained in the following table:

Table 3.2: Disbursements of DACF to District Assemblies in 2003 \& 2004

\begin{tabular}{|c|c|c|c|c|}
\hline REGION & DACF & $\begin{array}{l}\% \mathrm{OF} \\
\mathrm{TOTA} \\
\mathrm{L}\end{array}$ & $\begin{array}{r}\text { DACF } \\
2004\end{array}$ & $\begin{array}{l}\% \text { of } \\
\text { total }\end{array}$ \\
\hline WESTERN & $41,447,532,022$ & $9 \%$ & $71,641,767,423$ & $9 \%$ \\
\hline CENTRAL & $49,956,562,420$ & $11 \%$ & $69,530,599,951$ & $9 \%$ \\
\hline GAR & $30,984,717,707$ & $7 \%$ & $39,037,743,642$ & $5 \%$ \\
\hline VOLTA & $37,161,809,982$ & $8 \%$ & $79,207,129,644$ & $10 \%$ \\
\hline EASTERN & $61,944,890,265$ & $14 \%$ & $88,892,768,826$ & $12 \%$ \\
\hline ASHANTI & $79,553,383,698$ & $18 \%$ & $112,646,855,808$ & $15 \%$ \\
\hline BRONG AHAFO & $50,113,914,771$ & $11 \%$ & $106,316,594,164$ & $14 \%$ \\
\hline NORTHERN & $53,869,937,928$ & $12 \%$ & $104,772,944,274$ & $14 \%$ \\
\hline UPPER EAST & $27,053,858,496$ & $6 \%$ & $48,474,935,004$ & $6 \%$ \\
\hline UPPER WEST & $17,200,721,889$ & $4 \%$ & $50,933,461,265$ & $7 \%$ \\
\hline TOTALS & $449,287,329,178$ & $100 \%$ & $771,454,800,000$ & $100 \%$ \\
\hline MP's FUND & - & & $42,858,600,000$ & \\
\hline RCCs & - & & $21,429,300,000$ & \\
\hline ADMIN. OFFICE & - & & $6,882,835,000$ & \\
\hline RESERVE FUND & - & & $14,546,465,000$ & \\
\hline Grand TOTAL & & & $857,172,000,000$ & \\
\hline
\end{tabular}

Source: DACF Administrator's Office 
Despite the substantial amount voted to the RCCs to monitor the use of the DACF, monitoring reports are not regularly sent to the Administrator of the fund or to MLGRD. Some RPCUs complain that the vote for M\&E gets entangled in the RCC's expenditure and is hardly ever released to them for monitoring. The DACF Administrator's office, the Audit Service and the MLGRD should exercise more supervision over the use of the fund to ensure that it is in conformity with guidelines issued.

\subsection{UTILISATION OF THE DACF IN 2004}

In the year 2004, returns on the use of the DACF shows that an amount of $\phi 593,544,509,824$ was utilized by districts for development projects/programmes compared to $₫ 403,864,538,000$ in 2003. Analysis of these returns shows major expenditure patterns as follows:

- a large proportion (46\%) of the fund was expended on Governance and Local Government Administration;

- the proportion spent on Production \& Employment including the Poverty Alleviation MicroCredit loans to women groups was $23 \%$;

- Basic Education was 17\% and

- $12 \%$ went into providing Water \& Sanitation.

This analysis does not relate solely to disbursements to DAs in 2004 but is based on the continuous use of the fund for the 2004 period. Expenditures were largely on GPRS social sector priority areas.

Table 3.3: Summary of utilization of DACF during 2004 - Expenditure by sector

\begin{tabular}{|c|c|c|c|c|c|c|}
\hline REGION & HEALTH & $\begin{array}{c}\text { WATER \& } \\
\text { SANITATION }\end{array}$ & EDUCATION & $\begin{array}{c}\text { PRODUCTIO } \\
\text { N \& } \\
\text { EMPLOYMEN } \\
T\end{array}$ & $\begin{array}{c}\text { GOVERNANC } \\
\text { E \& } \\
\text { ADMINISTRA } \\
\text { TION }\end{array}$ & TOTAL \\
\hline WESTERN & $1,040,761,000$ & $5,849,556,000$ & $9,871,538,000$ & $15,927,159,000$ & $26,725,980,000$ & $59,414,994,000$ \\
\hline CENTRAL & $963,258,000$ & $6,649,763,000$ & $10,316,623,000$ & $17,501,964,000$ & $28,357,985,000$ & $63,789,593,000$ \\
\hline GT. ACCRA & $177,172,000$ & $9,773,420,000$ & $4,743,167,000$ & $5,260,684,000$ & $13,241,609,000$ & $33,196,052,000$ \\
\hline EASTERN & $371,194,000$ & $10,419,389,000$ & $20,062,667,000$ & $18,197,223,000$ & $33,681,375,000$ & $82,731,848,000$ \\
\hline VOLTA & $1,316,943,000$ & $7,700,395,000$ & $6,096,674,000$ & $13,990,537,000$ & $26,749,699,000$ & $55,854,248,000$ \\
\hline ASHANTI & $1,454,407,000$ & $11,430,834,000$ & $19,798,823,000$ & $22,103,120,000$ & $43,631,281,175$ & $98,418,465,175$ \\
\hline B. AHAFO & $1,479,605,000$ & $11,477,021,000$ & $8,623,020,000$ & $10,406,181,000$ & $33,057,054,000$ & $65,042,881,000$ \\
\hline $\begin{array}{l}\text { NORTHER } \\
\mathrm{N}\end{array}$ & $1,360,125,000$ & $4,577,482,649$ & $9,546,215,000$ & $16,039,446,000$ & $42,520,476,000$ & $74,043,744,649$ \\
\hline $\begin{array}{l}\text { UPPER } \\
\text { WEST }\end{array}$ & $62,747,000$ & $2,412,188,000$ & $6,041,876,000$ & $9,001,367,000$ & $11,717,886,000$ & $29,236,064,000$ \\
\hline $\begin{array}{l}\text { UPPER } \\
\text { EAST }\end{array}$ & $849,888,000$ & $2,359,154,000$ & $4,817,292,000$ & $7,506,924,000$ & $16,283,362,000$ & $31,816,620,000$ \\
\hline TOTAL & $9,076,100,000$ & $72,649,202,649$ & $99,917,895,000$ & $135,934,605,000$ & $275,966,707,175$ & $593,544,509,824$ \\
\hline
\end{tabular}

Source: DACF Administrator's Office 


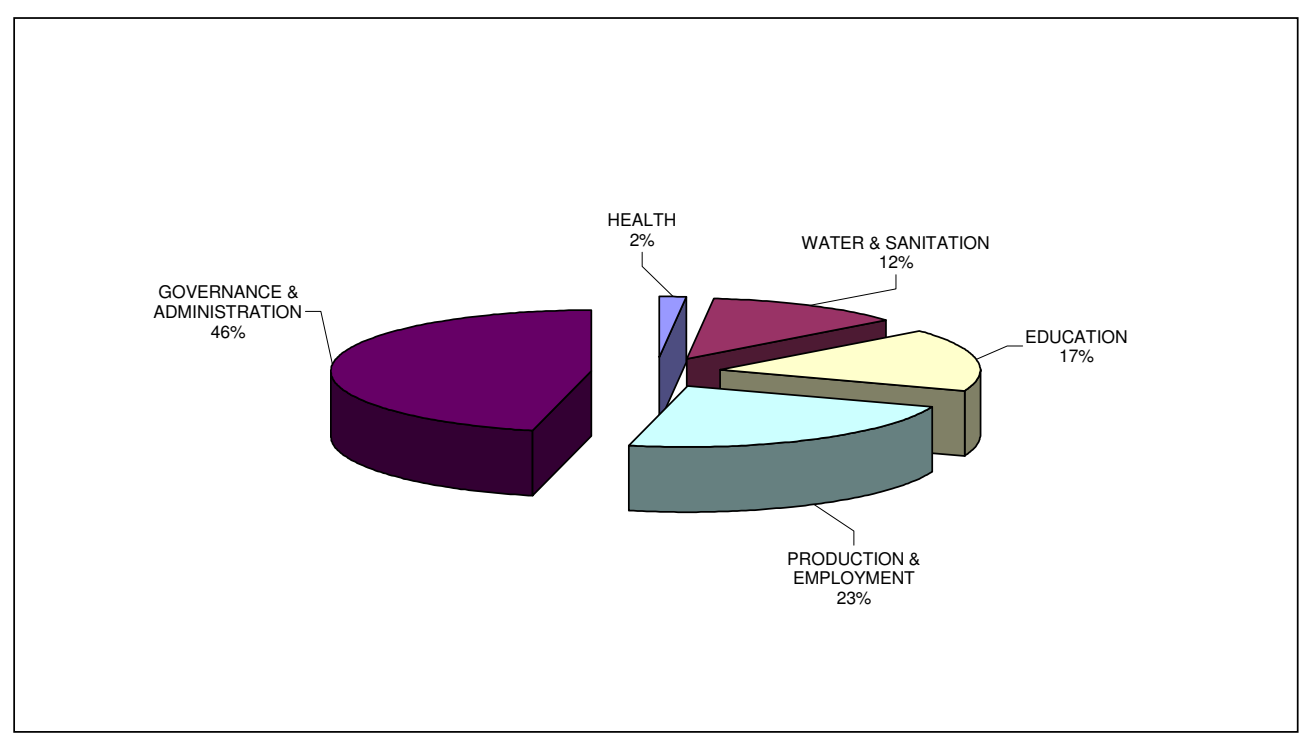

The large proportion of the DACF spent on governance and administration is not in line with guidelines for utilisation. Under this category, expenditure items include: improvement of markets, counterpart funding for donor \& community projects, electrification, investment, training, construction, printing, furniture, support for health campaign programmes, etc.

\subsection{INTERNALLY GENERATED REVENUE BY DISTRICT ASSEMBLIES}

Data for compiling the internally generated fund (IGF) performance of districts were obtained from the Ministry of Local Government and Rural Development. Districts submit to the MLGRD, on a monthly basis, Trial Balances on their financial performance and a few districts were still outstanding in the submission of this data for the last two months of 2004. The internally generated revenue accruing to District Assemblies is made up of revenue from fees \& fines, rates, lands, licences, investments and some other miscellaneous sources. The pie chart below shows the proportional contribution these items make to total IGF.

Chart 3.2: Percentage contribution to IGF by ITEM: 2004

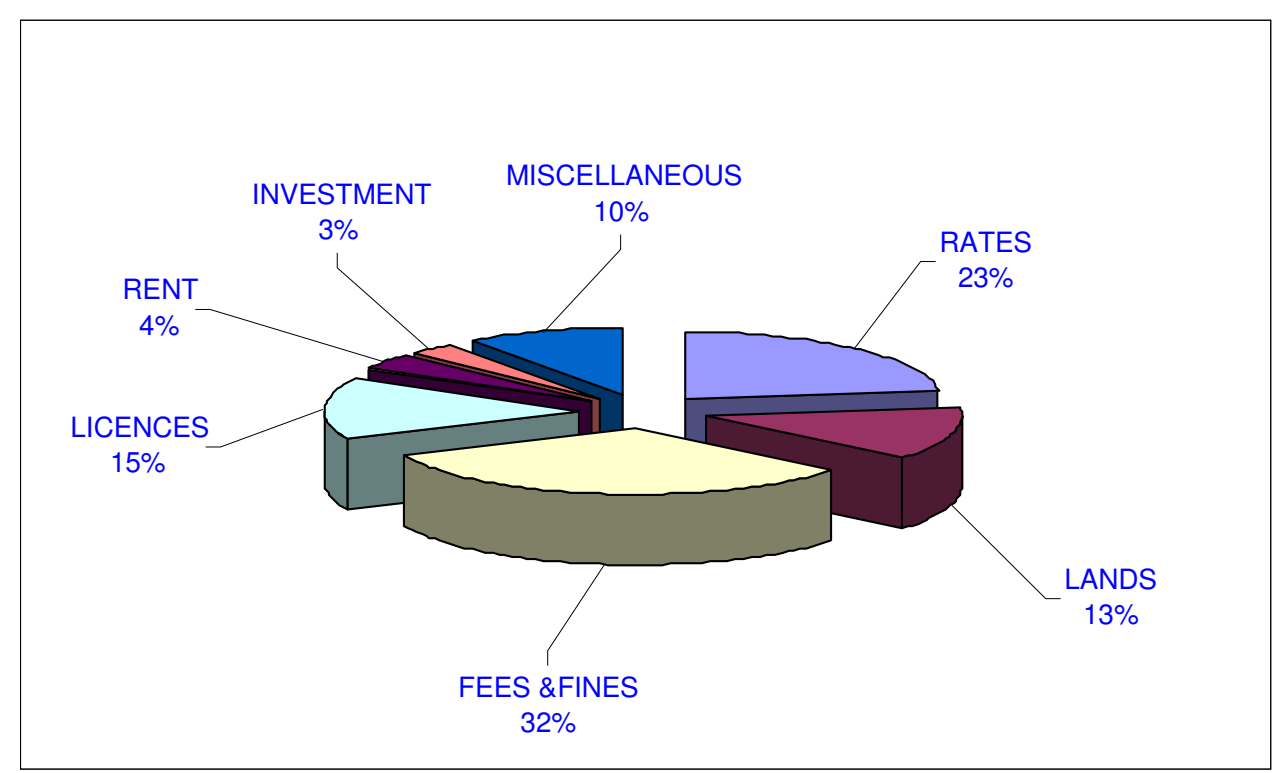


From the chart it is clear that the largest and most consistent source of IGF to DAs comes from fees \& fines contributing an average of $32 \%$ of IGF over the period 2000 to 2004. This is followed by rates $(23 \%)$, licences $(15 \%)$ and lands $(13 \%)$ in that order. The table below shows the yearly performance of DAs in revenue generation according to these items. Details of the contribution of these items to IGF by region, from 2000 to 2004 are shown in the Appendix.

Table 3.4 Internally Generated Revenue Performance by Item from 2000 - 2004

\begin{tabular}{|c|c|c|c|c|c|c|c|c|c|c|c|}
\hline \multirow[b]{2}{*}{ SOURCES OF IGF } & \multicolumn{2}{|c|}{2000} & \multicolumn{2}{|c|}{2001} & \multicolumn{2}{|c|}{2002} & \multicolumn{2}{|c|}{2003} & \multicolumn{2}{|c|}{2004} & \multirow[b]{2}{*}{ AVG \% } \\
\hline & $\begin{array}{c}\text { Portion of } \\
\text { IGF } \\
\end{array}$ & \begin{tabular}{|c|}
$\%$ \\
Contribution \\
to Total IGF \\
\end{tabular} & $\begin{array}{c}\text { Portion of } \\
\text { IGF }\end{array}$ & \begin{tabular}{|c|}
$\%$ \\
Contribution \\
to Total IGF \\
\end{tabular} & Portion of IGF & \begin{tabular}{|c|}
$\%$ \\
Contribution \\
to Total IGF \\
\end{tabular} & $\begin{array}{c}\text { Portion of IGF } \\
\text { d }\end{array}$ & \begin{tabular}{|c|}
$\%$ \\
Contribution \\
to Total IGF \\
\end{tabular} & Portion of IGF & \begin{tabular}{|c|}
$\%$ \\
Contribution \\
to Total IGF
\end{tabular} & \\
\hline RATE & $15,640,040,050$ & 22.22 & $21,922,537,548$ & 22.9 & $34,182,017,298$ & 23.9 & $43,433,487,952$ & 23.0 & $54,311,364,432$ & 24.1 & 23.2 \\
\hline LANDS & $8,140,230,907$ & 11.57 & $7,456,375,389$ & 7.8 & $17,687,981,298$ & 12.4 & $33,877,019,508$ & 17.9 & $33,930,079,955$ & 15.0 & 12.9 \\
\hline FEES \&FINES & $23,841,666,944$ & 33.88 & $33,135,399,595$ & 34.6 & $41,084,206,036$ & 28.8 & $55,662,377,081$ & 29.5 & $67,595,051,790$ & 29.9 & 31.3 \\
\hline LICENCES & $10,964,206,906$ & 15.58 & $15,308,548,349$ & 16.0 & $23,005,721,180$ & 16.1 & $25,835,861,898$ & 13.7 & $31,754,838,844$ & 14.1 & 15.1 \\
\hline RENT & $2,524,614,066$ & 3.59 & $3,625,939,670$ & 3.8 & $5,168,638,783$ & 3.6 & $10,439,295,216$ & 5.5 & $11,262,333,019$ & 5.0 & 4.3 \\
\hline INVESTMENT & $2,590,024,752$ & 3.68 & $4,003,233,374$ & 4.2 & $4,416,406,472$ & 3.1 & $4,985,941,814$ & 2.6 & $7,258,180,239$ & 3.2 & 3.4 \\
\hline MISCELLANEOUS & $6,656,261,516$ & 9.46 & $10,233,653,966$ & 10.7 & $17,352,549,478$ & 12.1 & $14,541,349,046$ & 7.7 & $19,707,266,922$ & 8.7 & 9.7 \\
\hline TOTAL & $70,357,045,141$ & 100 & $95,685,687,891$ & 100.0 & $142,897,520,545$ & 100 & $188,775,332,515$ & 100 & $225,819,115,201$ & 100 & 100.0 \\
\hline
\end{tabular}

Total IGF generated by all districts in the country increased in 2004 as shown in Table 3.4 and the corresponding bar chart below. This revenue totalled $₫ 225.819$ billion in 2004 compared to ¿188.775 billion for 2003 and this represents an increase of 20\%. Metropolitan and Municipal Assemblies generate more revenue than other districts. Total IGF figures by all districts in the country from 2000 to 2004 is shown in the table and the chart below.

Table 3.5 Regional Totals of Internally Generated Funds by District Assemblies 2000-2004

\begin{tabular}{|c|c|c|c|c|c|c|c|c|c|}
\hline \multirow[b]{2}{*}{ REGION } & \multirow{2}{*}{$\begin{array}{l}2000 \\
\text { IGF }\end{array}$} & \multicolumn{2}{|l|}{2001} & \multicolumn{2}{|l|}{2002} & \multicolumn{2}{|l|}{2003} & \multicolumn{2}{|l|}{2004} \\
\hline & & IGF & \begin{tabular}{c|}
$\%$ \\
Change \\
\end{tabular} & IGF & $\begin{array}{c}\% \\
\text { Change }\end{array}$ & IGF & $\begin{array}{c}\% \\
\text { Change }\end{array}$ & IGF & $\begin{array}{r}\% \\
\text { Change } \\
\end{array}$ \\
\hline Western & $7,321,403,738$ & $8,942,905,281$ & $22 \%$ & $17,315,653,021$ & $94 \%$ & $23,991,651,610$ & $39 \%$ & $34,339,657,784$ & $43 \%$ \\
\hline Central & $3,627,480,097$ & $5,030,190,224$ & $39 \%$ & $6,750,070,251$ & $34 \%$ & $7,654,058,042$ & $13 \%$ & $9,822,668,231$ & $28 \%$ \\
\hline Greater Accra & $30,750,047,304$ & $41,355,335,942$ & $34 \%$ & $52,023,798,596$ & $26 \%$ & $69,575,313,066$ & $34 \%$ & $85,726,748,624$ & $23 \%$ \\
\hline Eastern & $4,776,474,999$ & $5,671,567,217$ & $19 \%$ & $11,391,726,048$ & $101 \%$ & $13,188,660,409$ & $16 \%$ & $16,080,201,801$ & $22 \%$ \\
\hline Volta & $3,794,006,825$ & $5,037,532,993$ & $33 \%$ & $6,113,762,137$ & $21 \%$ & $6,750,283,885$ & $10 \%$ & $9,683,051,022$ & $43 \%$ \\
\hline Ashanti & $10,543,317,235$ & $14,959,976,423$ & $42 \%$ & $22,763,216,633$ & $52 \%$ & $30,848,249,664$ & $36 \%$ & $40,212,592,864$ & $30 \%$ \\
\hline Brong Ahafo & $4,788,926,093$ & $6,505,537,139$ & $36 \%$ & $10,375,344,273$ & $59 \%$ & $22,663,441,950$ & $118 \%$ & $14,105,063,123$ & $-38 \%$ \\
\hline Northern & $1,700,136,293$ & $2,493,972,590$ & $47 \%$ & $8,336,007,437$ & $234 \%$ & $5,608,194,767$ & $-33 \%$ & $4,779,110,645$ & $-15 \%$ \\
\hline Upper West & $1,194,524,631$ & $1,155,416,084$ & $-3 \%$ & $2,035,378,675$ & $76 \%$ & $4,383,501,728$ & $115 \%$ & $4,708,577,819$ & $7 \%$ \\
\hline Upper East & $1,860,727,926$ & $4,533,253,998$ & $144 \%$ & $5,792,563,474$ & $28 \%$ & $4,111,977,394$ & $-29 \%$ & $6,361,443,288$ & $55 \%$ \\
\hline TOTAL & $70,357,045,141$ & $95,685,687,891$ & $36 \%$ & $142,897,520,545$ & $49 \%$ & $188,775,332,515$ & $32 \%$ & $225,819,115,201$ & $20 \%$ \\
\hline
\end{tabular}


Figure 3.2: Internally generated revenue by district assemblies 2000 - 2004

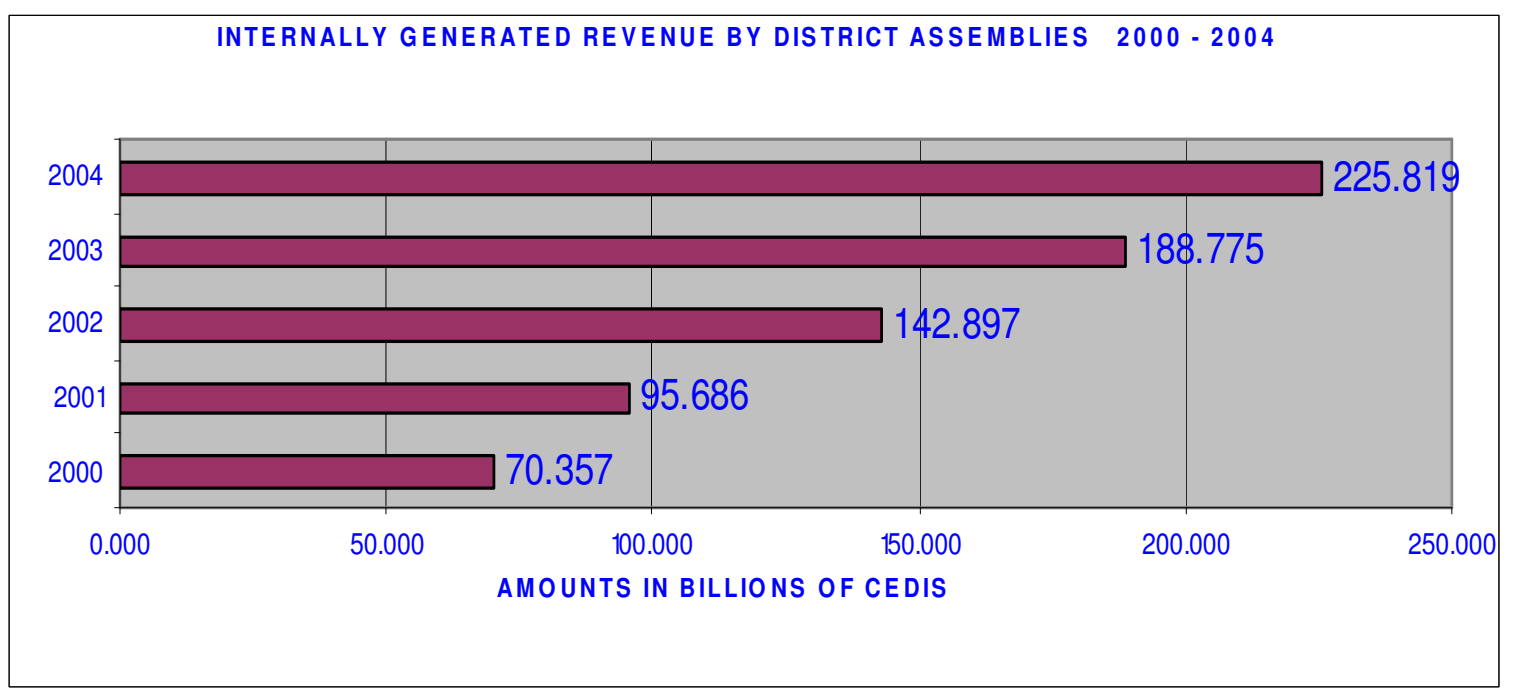

The increasing IGF totals mask a declining revenue performance for some districts. Many DAs are inconsistent in the declaration of internal revenue generated. Accountability and transparency is lacking in this area of their operation. Management of IGF is called into question when this situation is weighed against past audit reports. These reports noted instances of revenue not accounted for, non-lodgement of revenue on time, suppression or loss of value books and un-acquitted payment vouchers.

\subsection{COMPARING NOMINAL GROWTH TO REAL GROWTH IN IGF}

Real growth in IGF has been calculated by comparing it with the Consumer Price Index (CPI) annual average growth rates. This analysis is to find out if the increasing figures for IGF are real. When compared to the nominal growth there was great growth in IGF in 2002 but this marked improvement was not built on the following year even though nominal growth showed a $32 \%$ increase in IGF.

Table 3.6: Comparing nominal growth to real growth in IGF

\begin{tabular}{|l|c|c|c|c|}
\hline & $\mathbf{2 0 0 0 - 2 0 0 1}$ & $\mathbf{2 0 0 1 - 2 0 0 2}$ & $\mathbf{2 0 0 2 - 2 0 0 3}$ & $\mathbf{2 0 0 3 - 2 0 0 4}$ \\
\hline Nominal Growth in IGF & $36.00 \%$ & $49.00 \%$ & $32.00 \%$ & $20.00 \%$ \\
\hline CPI Annual Average & $32.90 \%$ & $14.80 \%$ & $26.70 \%$ & $12.60 \%$ \\
\hline Real Growth $\%$ in IGF & $3.10 \%$ & $34.20 \%$ & $5.30 \%$ & $7.40 \%$ \\
\hline
\end{tabular}

Figure 3.1: Real growth (\%) in internally generated revenue

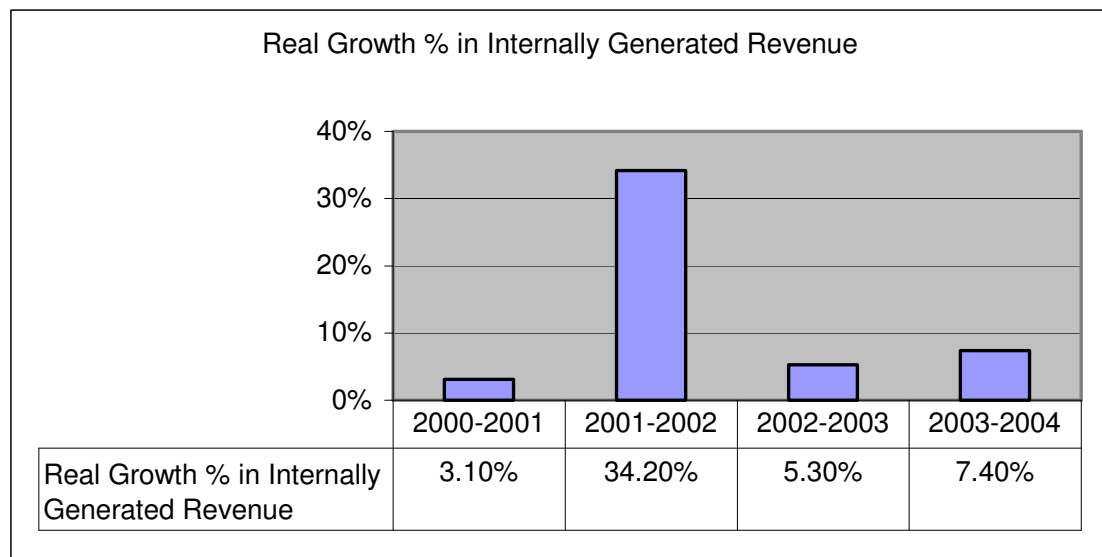


In addition to poor revenue generation, districts spend large proportions of their IGF on administration and recurrent expenses, leaving little or none for development. Districts are therefore still depending to a very large extent on external sources to fund their development plans. Given that internally generated revenue in some districts have drastically and inexplicably declined, the MLGRD will have to investigate the causes of decline in revenues.

\subsection{COMPARING DACF \& IGF}

The IGF as a percentage of DACF shows a decline from $54 \%$ in 2002 , to $29 \%$ in 2003 , and to $26 \%$ in 2004 . This indicates that revenue generated by central government increased at a faster rate than that generated by DAs. In sharing DACF to districts, performance in revenue generation is a factor in the formula for calculating each DA's allocation. Declarations of internally generated funds by districts therefore have to be independently verified/audited given the inconsistencies that are usually observed by the MLGRD in the Trial Balances submitted.

Table 3.7 Comparing DACF to IGF 2000 - 2004

\begin{tabular}{|l|c|c|c|}
\hline Year & $\begin{array}{c}\text { DACF } \\
\text { Amounts in Billions of Cedis }\end{array}$ & $\begin{array}{c}\text { Internally generated Revenue } \\
\text { Amounts in Billions of Cedis }\end{array}$ & $\begin{array}{c}\text { IGF as \% of } \\
\text { DACF }\end{array}$ \\
\hline $\mathbf{2 0 0 0}$ & 149.526 & 70.357 & $47 \%$ \\
\hline $\mathbf{2 0 0 1}$ & 188.729 & 95.685 & $51 \%$ \\
\hline $\mathbf{2 0 0 2}$ & 265.350 & 142.897 & $54 \%$ \\
\hline $\mathbf{2 0 0 3}$ & 648.562 & 188.775 & $29 \%$ \\
\hline $\mathbf{2 0 0 4}$ & 857.172 & 225.819 & $26 \%$ \\
\hline
\end{tabular}

\subsection{PROBLEMS IN THE MANAGEMENT OF DACF \& INTERNALLY GENERATED FUND}

- DAs still use development funds for recurrent expenditures which is in contravention of the law guiding the use of the DACF

- Management of the poverty alleviation loans (20\% of the District's DACF) is still not streamlined. Even though there are guidelines for granting the loans, these are not followed strictly and there is no serious recovery effort in many districts.

- RPCUs complain of not getting funds for monitoring even though there is an allocation from the DACF for this purpose.

- Failure of some RCCs to submit returns on the use of the Fund on time.

Some of the problems which audit reports highlighted in the past in the management of DA financial resources are still prevalent. Some of these are:

○ Un-acquitted payment vouchers

- Missing value books and revenue not accounted for

- Revenue collectors not bonded

- Outstanding loans and advances to staff of the DA

- Failure of Assembly officials to account for and retire cash imprest advanced to them in the course of performing their official duties etc. 


\subsection{DISBURSEMENT OF HIPC RELIEF FUNDS IN 2004}

Data on HIPC funds disbursements to MDAs was provided by the CAGD up to December 2004. The total amount transferred to MDAs in 2004 by the Controller and Accountant General is $\notin 1,817$ billion compared to 842 billion in 2003 .

\subsection{UTILISATION OF HIPC FUNDS}

A substantial portion $(16.59 \%)$ of the fund has also been used to defray the Domestic Debt. Apart from the allocation for domestic debt, the MLGRD and District Assemblies received the biggest allocation of HIPC funds in 2004 receiving $16.22 \%$ of the total sum disbursed. Other sectors that benefited most from HIPC funds in 2004 are Education (15.84\%), Works \& Housing [water \& sanitation] (8.20\%), Energy (6.39\%), and Health (6.11\%). These disbursements are in conformity with the Medium Term Priorities (MTPs) of government set out in the GPRS.

But, there are still no clear guidelines nor a budget followed in the disbursement of HIPC funds to MDAs and other beneficiaries. The disbursement procedure follows the issuance of an authorisation, in the form of a letter, from the Ministry of Finance to the CAGD to pay the beneficiary MDA.

Details of amounts disbursed by the CAGD from the HIPC Account to MDAs in 2004 are shown in the table below.

Table 3.8: Disbursement of HIPC Funds in 2004(Amounts in Cedis)

\begin{tabular}{|l|r|r|}
\hline BANK OF GHANA (Payment for Domestic Debt) & $301,400,000,000.00$ & $16.59 \%$ \\
\hline Ministry of Local Government \& Rural Dev. & $294,727,354,384.03$ & $16.22 \%$ \\
\hline Ministry of Education Youth \& Sports & $287,809,895,286.29$ & $15.84 \%$ \\
\hline Ministry of Works \& Housing & $149,000,041,538.84$ & $8.20 \%$ \\
\hline Ministry of Energy & $116,116,806,326.36$ & $6.39 \%$ \\
\hline Office of Government Machinery, OGM & $111,698,062,803.56$ & $6.15 \%$ \\
\hline Ministry of Health & $110,926,091,856.21$ & $6.11 \%$ \\
\hline Ministry of Roads \& Transport & $72,919,105,965.02$ & $4.01 \%$ \\
\hline Ministry of Lands \& Forestry & $70,846,297,700.00$ & $3.90 \%$ \\
\hline Ministry of Interior & $55,674,561,872.00$ & $3.06 \%$ \\
\hline Ministry of Finance \& Economic Planning & $53,080,363,500.00$ & $2.92 \%$ \\
\hline Ministry of Trade \& Industry & $51,729,086,730.00$ & $2.85 \%$ \\
\hline Office of Parliament & $25,000,000,000.00$ & $1.38 \%$ \\
\hline Ministry of Food \& Agriculture & $24,229,158,493.40$ & $1.33 \%$ \\
\hline Ministry of Manpower Dev. \& Employment & $16,697,049,187.25$ & $0.92 \%$ \\
\hline Ministry of Communication \& Technology & $13,224,273,970.00$ & $0.73 \%$ \\
\hline Ministry of Women \& Children & $13,035,220,000.00$ & $0.72 \%$ \\
\hline Ministry of Private Sector Development & $9,108,550,000.00$ & $0.50 \%$ \\
\hline Ministry of Information & $6,864,950,000.00$ & $0.38 \%$ \\
\hline Judicial Service & $6,638,500,000.00$ & $0.37 \%$ \\
\hline Electoral Commission & $5,384,661,755.00$ & $0.30 \%$ \\
\hline Ministry of Tourism \&MCC & $5,199,820,521.00$ & $0.29 \%$ \\
\hline Ministry of Mines & $4,470,000,000.00$ & $0.25 \%$ \\
\hline National Commission on Culture & $2,500,000,000.00$ & $0.14 \%$ \\
\hline Ministry of Parliamentary Affairs & $2,000,000,000.00$ & $0.11 \%$ \\
\hline Ministry of Finance \& Economic Planning & $1,532,432,500.00$ & $0.08 \%$ \\
\hline Ministry of Justice & $1,501,000,000.00$ & $0.08 \%$ \\
\hline
\end{tabular}




\begin{tabular}{|l|r|r|}
\hline National Media Commission & $1,049,622,000.00$ & $0.06 \%$ \\
\hline Audit Service & $1,044,385,237.50$ & $0.06 \%$ \\
\hline CHRAJ & $900,000,000.00$ & $0.05 \%$ \\
\hline Ministry of Environment \& Science & $554,460,000.00$ & $0.03 \%$ \\
\hline Grand Total & $\mathbf{1 , 8 1 6 , 8 6 1 , 7 5 1 , 6 2 6 . 4 6}$ & $\mathbf{1 0 0 . 0 0 \%}$ \\
\hline
\end{tabular}

Source: Controller and Accountant General's Department 
Figure 3.4: Disbursement of HIPC Fund in 2004

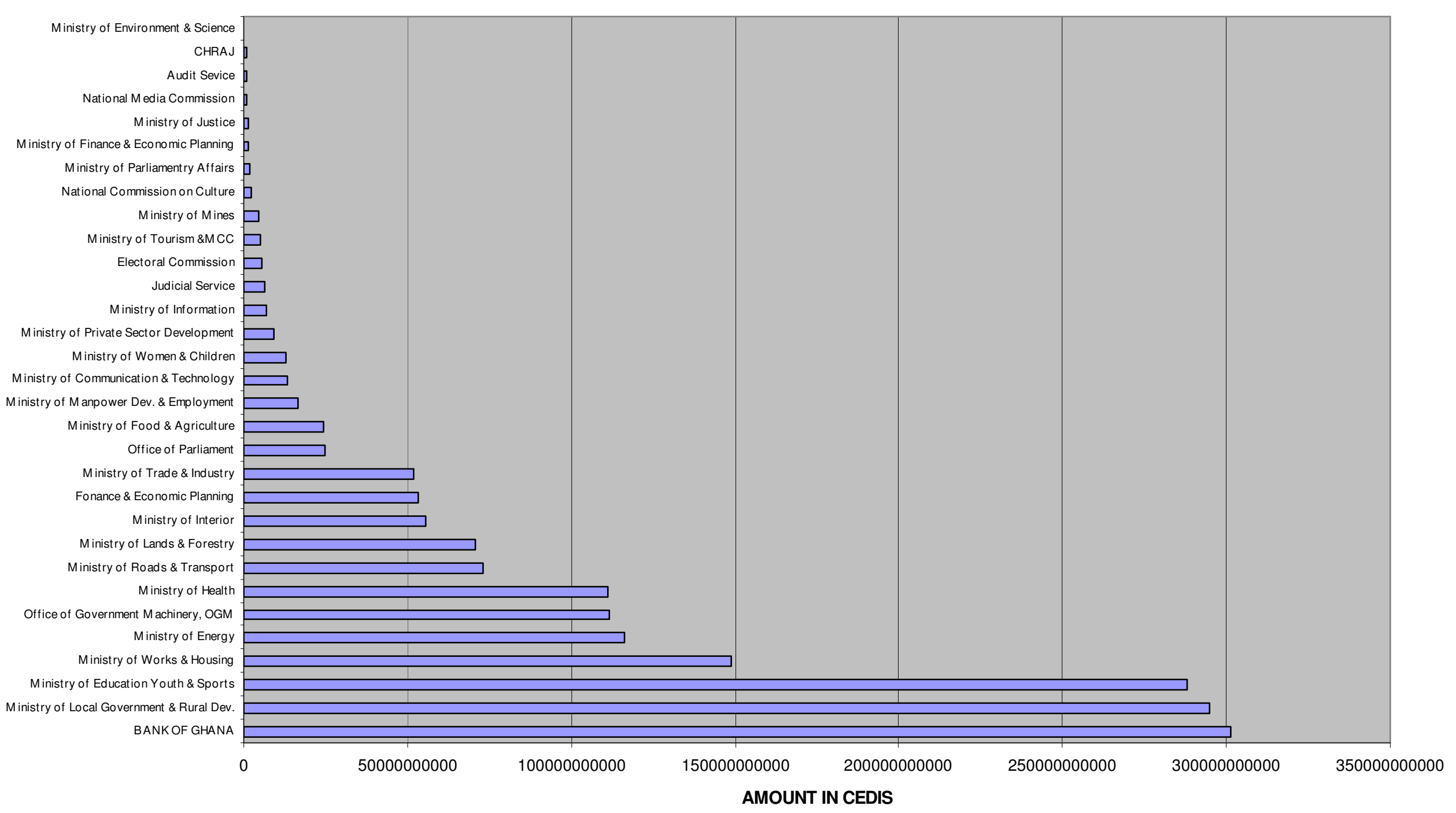


Table 3.9: HIPC Funds transferred to MDAs 2002 - 2004 (Amounts in cedis)

\begin{tabular}{|c|c|c|c|c|}
\hline & MDA & 2002 & 2003 & 2004 \\
\hline 1 & BOG (Payment for Domestic Debt) & $81,400,000,000$ & $144,000,000,000$ & $301,400,000,000$ \\
\hline 2 & Ministry of Local Government \& Rural Development & $126,677,475,568$ & $101,720,478,015$ & $294,727,354,384$ \\
\hline 3 & Ministry of Education Youth \& Sports & nil & $188,653,275,075$ & $287,809,895,286$ \\
\hline 4 & Ministry of Works \& Housing & $3,010,128,603$ & $105,123,147,119$ & $149,000,041,539$ \\
\hline 5 & Ministry of Energy & $519,758,328$ & $35,111,346,154$ & $116,116,806,326$ \\
\hline 6 & Ministry of Health & nil & $70,827,992,137$ & $110,926,091,856$ \\
\hline 7 & Office of Government Machinery & nil & nil & $111,698,062,804$ \\
\hline 8 & Ministry of Roads \& Transport & nil & $87,168,558,128$ & $72,919,105,965$ \\
\hline 9 & Ministry of Lands \& Forestry & nil & $10,999,800,000$ & $70,846,297,700$ \\
\hline 10 & Ministry of Interior & $2,491,435,000$ & $18,941,264,192$ & $55,674,561,872$ \\
\hline 11 & Ministry of Finance & nil] & nil & $53,080,363,500$ \\
\hline 12 & Ministry of Trade, Industry \& PSI & $4,502,381,000$ & $13,583,133,914$ & $51,729,086,730$ \\
\hline 13 & Office of Parliament & nil & nil & $25,000,000,000$ \\
\hline 14 & Ministry of Food \& Agriculture & nil & $16,420,642,575$ & $24,229,158,493$ \\
\hline 15 & Ministry of Manpower Development \& Employment & nil & $7,610,000,000$ & $16,697,049,187$ \\
\hline 16 & Ministry of Communication & nil & $5,854,565,000$ & $13,224,273,970$ \\
\hline 17 & Ministry of Women \& Children Affairs & $14,966,362,500$ & $12,000,000,000$ & $13,035,220,000$ \\
\hline 18 & Ministry of Private Sector Development & nil & $8,700,000,000$ & $9,108,550,000$ \\
\hline 19 & Ministry of Information & $3,501,100,000$ & $8,160,000,000$ & $6,864,950,000$ \\
\hline 20 & Judicial Service & nil & nil & $6,638,500,000$ \\
\hline 21 & National Electoral Commission & nil & nil & $5,384,661,755$ \\
\hline 22 & Min. of Tourism \& Modernisation - Capital City & nil & $5,807,469,479$ & $5,199,820,521$ \\
\hline 23 & Ministry of Mines & $3,231,519,000$ & nil & $4,470,000,000$ \\
\hline 24 & National Commission on Culture & nil & nil & $2,500,000,000$ \\
\hline 25 & Ministry of Parliamentary Affairs & nil & nil & $2,000,000,000$ \\
\hline 26 & NEPAD \& Regional Co-op. NEPAD & $9,922,500,000$ & $550,000,000$ & $1,532,432,500$ \\
\hline 27 & Ministry of Justice & nil & nil & $1,501,000,000$ \\
\hline 28 & National Media Commission & nil & nil & $1,049,622,000$ \\
\hline 29 & Audit Service & nil & nil & $1,044,385,238$ \\
\hline 30 & CHRAJ & nil & nil & $900,000,000$ \\
\hline 31 & Ministry of Environment \& Science & nil & nil & $554,460,000$ \\
\hline 32 & Office of the Senior Minister & $18,600,000,000$ & nil & nil \\
\hline 33 & Ministry of Defence & nil & $846,901,072$ & nil \\
\hline & Total & $268,822,659,999$ & $842,078,572,861$ & $1,816,861,751,626$ \\
\hline
\end{tabular}

Source: Controller and Accountant General's Department

Since accessing the HIPC initiative, benefits to citizens resulting from the HIPC relief fund are evident from the increasing amounts transferred to MDAs and DAs over the years (Table 3.9) above table. HIPC relief funds to the MDAs are spent mainly on programmes and activities outlined in the GPRS and listed in the thematic areas. 


\section{Policy Recommendations}

- Even though the process began in Parliament to increase the DACF to 7.5\% there has not been any action on this matter. The MLGRD and the DACF Administrator should expedite action so that more resources will get transferred to the districts.

- Assemblies should publish DACF expenditure patterns in their newsletters and on notice boards at their Assemblies to allow for greater transparency and monitoring.

- The MLGRD should insist on compliance with the reviewed Act 59 (Financial Memoranda issued to MMDAs) governing the management of their finances. Sanctions should be brought to bear on DAs and offending officials should be vigorously prosecuted.

- Revenue generation / collection by District Assemblies are still inconsistent and not all areas for revenue are covered or explored. The MLGRD should therefore initiate policy to encourage private participation in revenue generation by districts.

- The process of allocation and disbursement of the HIPC Fund by the Ministry of Finance should be improved and guided by a budget or a transparent allocation formula with a contingency to allow for transparency and the proper controls.

- Other RPCUs together with DPCUs should take steps to draw up monitoring designs/plans for their regions as has been accomplished in the Upper East region. District Assemblies should devote some funds for Monitoring and Evaluation of their activities. 


\section{CHAPTER FOUR}

\section{MACROECONOMIC STABILITY}

\subsection{INTRODUCTION}

This section focuses on the Macroeconomic Stability thematic area. The focus of macrostability in the medium term is to ensure prudent fiscal and monetary policy management to achieve price stability, maintain interest rate levels that are conducive to both savings and investments, and to ensure stable yet competitive exchange rates and a fiscally sustainable debt burden. The GoG with its development partners have defined a number of macroeconomic targets and measures, which fall under broad policy objectives. In line with the Medium Term Priority (MTP) in the GPRS, the Multi Donor Budgetary Support (MDBS) initiative, the Poverty Reduction and growth Facility (PRGF) and the Poverty Reduction Support Credit (PRSC) process, various policy objectives have been set to achieve macro-stability.

The economy has achieved macro-stability. The macroeconomic indicators show that targets set by government have been achieved and this has led to a stable economic environment, with reduced inflation, lower interest rates, a relatively stable currency, and a strong external reserves position. This has been achieved partly through improved fiscal management, prudent monetary management and agricultural growth specifically in the cocoa sector. These achievements are expected to lead to increased incomes in the growth inducing areas. The increased poverty reduction expenditures are also expected to improve the livelihoods of poor households.

\subsection{REVIEW OF THE IMPLEMENTATION OF 2003 APR POLICY RECOMMENDATIONS}

In the 2003 APR several policy initiatives were suggested and were expected to be implemented by government. Table 4.1 summarises these policy initiatives and the progress made towards their implementation in 2004. It seems satisfactory progress has been made in the implementation of many of the initiatives.

Table 4.1: Status of Implementation of 2003 APR Policy Recommendations

\begin{tabular}{|l|l|}
\hline 2003 APR Policy Recommendations & Status in 2004 \\
\hline $\begin{array}{l}\text { 1. Without losing control over macro-stability the } \\
\text { government will simultaneously pursue more } \\
\text { ambitious growth policies, which will propel } \\
\text { the economy to a higher growth rate than } \\
\text { hovering around 5\%. }\end{array}$ & $\begin{array}{l}\text { The government in the 2004 Budget targeted a less } \\
\text { ambitious growth rate of } 5.2 \% \text {, but the economy } \\
\text { achieved a rate of } 5.8 \% \text {, which is still below rates } \\
\text { that can propel the economy to a middle income } \\
\text { status by } 2015 .\end{array}$ \\
\hline $\begin{array}{l}\text { 2. The government will continue to reduce the debt } \\
\text { burden by increasing revenue collection } \\
\text { through further improvements in the efficiency } \\
\text { of the revenue collecting agencies. }\end{array}$ & $\begin{array}{l}\text { Debt burden reduced from 22.6\% of GDP in 2003 } \\
\text { to } 17.6 \% \text { in } 2004 . \\
\text { Domestic Revenue increased from 20.8\% of GDP } \\
\text { in } 2003 \text { to 23.8\% in 2004 through efficiency } \\
\text { improvements }\end{array}$ \\
\hline $\begin{array}{l}\text { 3. The government will use an optimum mix of } \\
\text { appropriate fiscal and monetary policies to } \\
\text { deliver on inflation and other macroeconomic } \\
\text { targets and continue to strengthen public }\end{array}$ & $\begin{array}{l}\text { The goal of monetary policy has been to focus on } \\
\text { reducing the rate of inflation towards single digits. } \\
\text { The BOG used open market operations and } \\
\text { adjustments to the prime rate to achieve this. This }\end{array}$ \\
\hline
\end{tabular}



resulted in declines in inflation rate from $23.6 \%$ to $11.8 \%$ in 2004. Other macro targets achieved; Public Financial Management Reform Program (PUFMARP) made significant progress with regard to implementation of remaining components.

4. The government plans to use the TOR Debt Recovery Fund, which is expected to yield $\notin 1.2$ trillion to partly fund the subsidies for the delayed petroleum price adjustments.

5. The government also plans to close the unplanned financing gap through fiscal adjustments which consist of curtailing discretionary expenditures but protecting poverty reduction expenditures, reducing net domestic debt repayments from $2.2 \%$ of GDP to about $1.5 \%$, and finding more sources of revenue (non-tax revenue) through accelerated divestiture and increased dividends from stateowned companies.

6. Government expenditures as published do not clearly show the extent to which the poor benefited, especially the deprived areas of Northern, Upper East and Upper West and Central Regions. A more detailed breakdown of expenditure will be provided to forge a closer link between budget allocations and beneficiary targets.

7. The areas of budget formulation, execution and reporting still need upgrading and the link between the budget and GPRS would be strengthened further. The Budget and Public Expenditure Management System will be expanded to six other MDAs by November 2004.

8. As part of the Public Financial Management Reform Programme the Ministry of Finance and Economic Planning will operationalise the Financial Administration Act, the Internal Audit Agency Act and the Public Procurement Act as well as enhance the activities of the External Audit Act.

9. The government expects timely disbursement of pledges by Development Partners and will encourage donors that are not party to the MDBS to join
The government transferred subsidies of $₫ 1772.3$ billion to TOR for under-recovery in their operations resulting from non-adjustment of petroleum prices in 2004 .

Although a budget deficit of $3.2 \%$, poverty reduction expenditures were protected and even increased to $28.13 \%$ of government spending. Increase in non-tax revenue to $5.6 \%$ of domestic revenue as against a target of $3 \%$.

Expenditure breakdowns are still not detailed enough to show the extent of allocation of resources to deprived areas.

Upgrading in progress. BPEMS expanded to other MDAs

Several activities were undertaken to operationalise the Acts

Following the passage of the three Public Financial Management laws - the Financial Administration Act, 2003 (Act 654), the Internal Audit Agency Act, 2003 (Act 658), and the Public Procurement Act, 2003 (Act 663), to operationalise the laws the MFEP conducted a nationwide educational and awareness programme for over 10,000 people drawn from the Executive (including the President and his Ministers), Public and Private Sectors and Development Partners from March 2004 to December 2004.

Total disbursement of foreign loans exceeded budget estimates by 804.2 billion cedis. Through the Multi-Donor Budgetary Support Framework for the first time in the country's history, there was100 percent disbursement of donor pledges to support the budget in the implementation of the GPRS in the last two consecutive years. 


\begin{tabular}{|l|l|}
\hline $\begin{array}{l}\text { 10. The Bank of Ghana will work to diffuse the } \\
\text { inefficient institutional structures in the } \\
\text { financial sector to allow for a well-functioning } \\
\text { financial sector which impacts on growth and } \\
\text { thus helps to reduce poverty. }\end{array}$ & $\begin{array}{l}\text { The BOG geared its policies in line with the } \\
\text { commitments of government. Some progress was } \\
\text { made towards the reform of the financial sector. } \\
\text { The Bank initiated the Central System Depository } \\
\text { for Securities and the interbank payments system. }\end{array}$ \\
\hline $\begin{array}{l}\text { 11. The unemployment rate is a critical macro } \\
\text { indicator of welfare but is not routinely } \\
\text { reported on. Government will work hard to } \\
\text { ensure that labour market information be made } \\
\text { available more frequently. }\end{array}$ & $\begin{array}{l}\text { This objective has not been achieved. Labour } \\
\text { market information is still difficult to come by. }\end{array}$ \\
\end{tabular}

\subsection{TRENDS IN MACROECONOMIC INDICATORS}

Table 4.2 presents the performance of selected macroeconomic indicators for the period 2001 to 2004.

Table 4.2: Selected Macroeconomic Indicators

\begin{tabular}{|c|c|c|c|c|c|c|c|}
\hline INDICATOR & 2001 & 2002 & $\begin{array}{c}2003 \\
\text { GPRS } \\
\text { Target }\end{array}$ & $\begin{array}{c}2003 \\
\text { Actual }\end{array}$ & $\begin{array}{c}2004 \\
\text { GPRS } \\
\text { Target }\end{array}$ & $\begin{array}{c}2004 \\
\text { Budget }\end{array}$ & $\begin{array}{c}2004 \\
\text { Actual }\end{array}$ \\
\hline Real GDP Growth rate & 4.2 & 4.5 & 4.7 & 5.2 & 5.0 & 5.2 & 5.8 \\
\hline $\begin{array}{l}\text { Real Per capita GDP growth rate (Core } \\
\text { indicator) }\end{array}$ & 1.6 & 1.8 & 2.1 & 2.6 & 2.4 & 2.6 & 3.2 \\
\hline $\begin{array}{l}\text { Real Agric growth rate (\%) } \\
\text { Real Per capita Agric growth rate (Core } \\
\text { indicators) }\end{array}$ & $\begin{array}{l}4.0 \\
1.4 \\
\end{array}$ & $\begin{array}{l}4.4 \\
1.8 \\
\end{array}$ & $\begin{array}{l}4.5 \\
1.9 \\
\end{array}$ & $\begin{array}{l}6.1 \\
3.5 \\
\end{array}$ & $\begin{array}{l}4.8 \\
2.2 \\
\end{array}$ & $\begin{array}{r}6.0 \\
3.4 \\
\end{array}$ & $\begin{array}{r}7.5 \\
4.9 \\
\end{array}$ \\
\hline $\begin{array}{l}\text { Food crop growth rate } \\
\text { Real Per capita Food Crop growth rate }\end{array}$ & $\begin{array}{l}5.0 \\
2.4\end{array}$ & $\begin{array}{l}5.2 \\
2.6\end{array}$ & $\begin{array}{l}4.8 \\
2.2\end{array}$ & $\begin{array}{l}5.3 \\
2.7\end{array}$ & & & $\begin{array}{l}5.4 \\
2.8\end{array}$ \\
\hline Food Price Inflation (Core indicator) & 16.7 & 22.0 & 15.0 & 21.5 & & & 15.5 \\
\hline $\begin{array}{l}\text { Growth of Domestic revenue (Core } \\
\text { indicator) } \\
\text { Domestic revenue (excluding) as \% of } \\
\text { GDP }\end{array}$ & 43.29 & $\begin{array}{l}27.6 \\
18.0\end{array}$ & 22.3 & $\begin{array}{l}56.2 \\
20.8\end{array}$ & 22.3 & 22.4 & $\begin{array}{l}38.24 \\
21.2\end{array}$ \\
\hline $\begin{array}{l}\text { Growth of Credit to Agriculture (Core } \\
\text { indicator) }\end{array}$ & 20.83 & 9.04 & & 51.12 & & & 20.67 \\
\hline $\begin{array}{l}\text { Proportion of total resources going to } \\
\text { key GPRS sectors (Core indicator) }\end{array}$ & 64.75 & 79.6 & & 74.78 & 79.45 & 70.5 & $?$ \\
\hline Domestic Debt to GDP ratio & 20.9 & 23.9 & 23.6 & 18.3 & 17.8 & & 15.2 \\
\hline $\begin{array}{l}\text { Proportion of official bilateral HIPC } \\
\text { debt cancelled }\end{array}$ & & & & $\mathrm{N} / \mathrm{A}$ & & & 77.9 \\
\hline $\begin{array}{l}\text { Debt service as a } \% \text { of exports of goods } \\
\text { and services }\end{array}$ & 10.1 & 10.2 & 15.6 & 5.2 & 13.4 & & 3.6 \\
\hline $\begin{array}{l}\text { Proportion of ODA provided } \\
\text { as debt relief }\end{array}$ & & & & 0.9 & & & 19.5 \\
\hline Annual Average CPI & 32.9 & 14.8 & 15.1 & 26.7 & 8.0 & & 12.6 \\
\hline Year on year CPI & 21.3 & 15.2 & 9.0 & 23.6 & 7.0 & Below 10\% & 11.8 \\
\hline $\begin{array}{l}\text { Gross international Reserves (months of } \\
\text { imports of goods and services }\end{array}$ & 1.2 & 1.9 & 2.3 & 3.2 & 2.7 & 3.0 & 3.7 \\
\hline
\end{tabular}




\subsubsection{Real GDP/Per Capita Growth}

The GDP growth rate of 2004 of $5.8 \%$, like that of 2003 exceeded the budget projection of $5.2 \%$ and was also better than the target of $5.0 \%$ in the GPRS for the medium term. The basis of this high growth rate was the outstanding performance of $7.5 \%$ by the agricultural sector as against the growth of $6.1 \%$ achieved in 2003 .

Table 4.3: Percentage Sectoral Growth Rates (2002-2004)

\begin{tabular}{|l|c|c|c|c|c|}
\hline & $\mathbf{2 0 0 2}$ & $\mathbf{2 0 0 3}$ & $\begin{array}{c}\text { GPRS 2004 } \\
\text { Target }\end{array}$ & $\begin{array}{c}\text { 2004 } \\
\text { Budget }\end{array}$ & $\begin{array}{c}\text { 2004 Prov. } \\
\text { (Actual) }\end{array}$ \\
\hline GDP & $\mathbf{4 . 5}$ & $\mathbf{5 . 2}$ & $\mathbf{5 . 0}$ & $\mathbf{5 . 2}$ & $\mathbf{5 . 8}$ \\
\hline Agriculture & $\mathbf{4 . 4}$ & $\mathbf{6 . 1}$ & $\mathbf{4 . 8}$ & $\mathbf{6 . 0}$ & $\mathbf{7 . 5}$ \\
\hline Crops and Livestock & 5.2 & 5.3 & & & 5.4 \\
\hline Cocoa & -0.5 & 16.4 & & & 29.9 \\
\hline Forestry \&Logging & 5.0 & 6.1 & & & 5.8 \\
\hline Fishing & 2.8 & 3.0 & & & 3.5 \\
\hline Industry & $\mathbf{4 . 7}$ & $\mathbf{5 . 1}$ & $\mathbf{5 . 2}$ & $\mathbf{5 . 2}$ & $\mathbf{5 . 1}$ \\
\hline Mining and Quarrying & 4.5 & 4.7 & & & 4.5 \\
\hline Manufacturing & 4.8 & 4.6 & & & 4.6 \\
\hline Electricity and Water & 4.1 & 4.2 & & & 3.7 \\
\hline Construction & 5.0 & 6.1 & & & 6.6 \\
\hline Services & 4.7 & 4.7 & $\mathbf{5 . 1}$ & $\mathbf{4 . 7}$ & $\mathbf{4 . 7}$ \\
\hline $\begin{array}{l}\text { Transport, Storage and } \\
\text { Communication }\end{array}$ & 5.7 & 5.8 & & & 5.6 \\
\hline Wholesale, Trade \& Retail & 5.6 & 5.0 & & & 4.9 \\
\hline Finance and Insurance & 5.5 & 5.2 & & & 4.8 \\
\hline Government Services & 3.6 & 4.0 & & & 4.4 \\
\hline $\begin{array}{l}\text { Community, Social and } \\
\text { Personal Services }\end{array}$ & 4.4 & 4.1 & & & 4.2 \\
\hline Producers of Private Services & 3.1 & 3.3 & & & 3.5 \\
\hline
\end{tabular}

Sources: 2003-2005 Budget Statements

This growth in agriculture was fuelled by a $29.9 \%$ surge in cocoa production. Industrial growth remained stagnant at $5.1 \%$ having improved from $4.7 \%$ in 2002 with construction being the largest contributor of growth in the sector. The service sector performance was not encouraging compared to 2003 with only marginal increases in the performances of the various sub-sectors within the sector.

With an assumption of a stable population growth of $2.6 \%$, per capita growth rate improved from below 2\% since 2001 to $2.6 \%$ in 2003 and then to $3.2 \%$ in 2004, still low to make any significant impact on the conditions of the poor.

\subsubsection{Trends in Inflation}

The inflation rate measured by the CPI was $23.6 \%$ by the end of 2003 , the rate having been fuelled by the increase in petroleum prices in February of that year. By the end of 2004 the rate of inflation rate was $11.8 \%$ with the food component decreasing from $21.5 \%$ in December 2003 to $15.5 \%$ by December 2004, while there was a significant decline in the non-food component rate from $26.6 \%$ to $7.9 \%$ over the same period. The fall in the rate of inflation has been attributed to a combination of factors, including:

- improved food supply;

- monetary restraint; and

- a relatively stable exchange rate in an environment of diminishing inflationary expectations; 
- improved fiscal performance in the face of election year and donor inflows.

Figure 4.1: Year-on-Year Rates of Inflation (2002-2004)

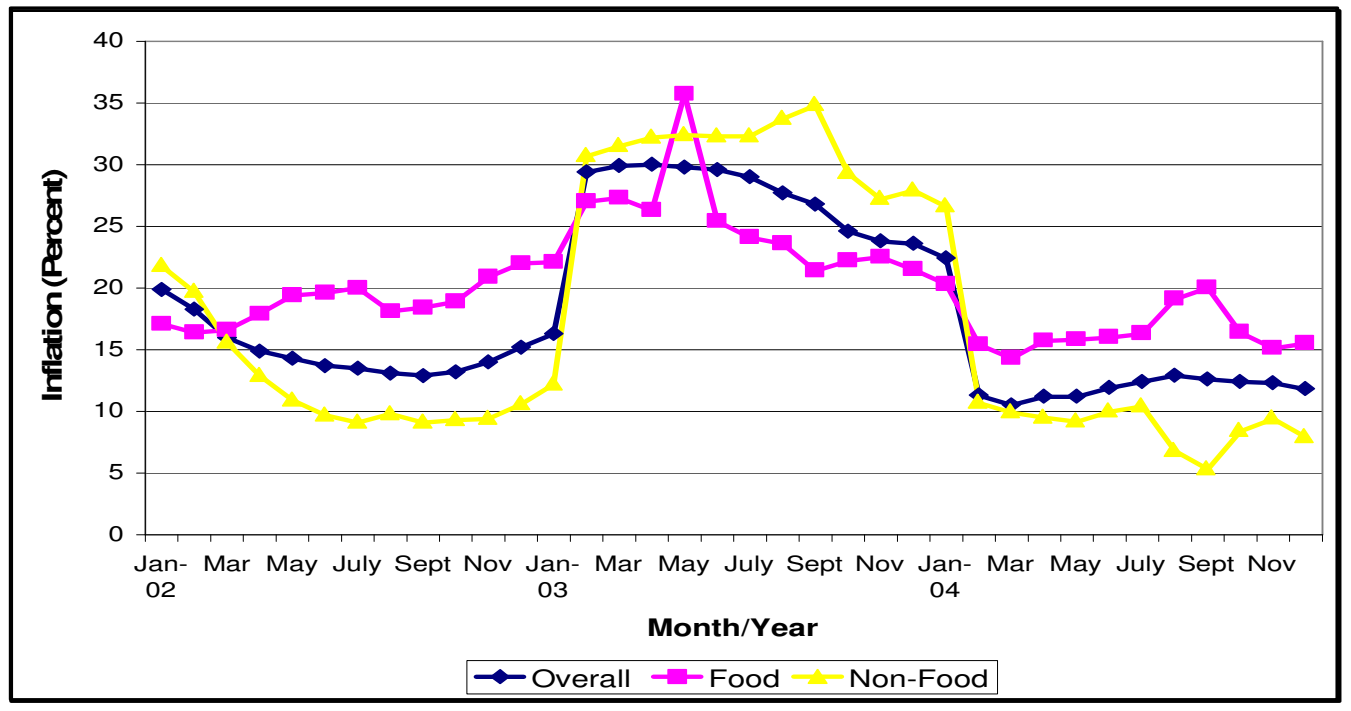

Source: Ghana Statistical Service

\subsubsection{External Developments}

The strength of the cedi in relation to the major currencies broadly reflected the strengths of those currencies on the international market. The foreign exchange market was fairly stable with the depreciation of the cedi against major currencies being lower in 2004 than 2003. Improved foreign exchange liquidity, fiscal discipline and a firm commitment to the monetary programme accounted for the successes achieved in the foreign exchange market.

On the interbank market, the cedi depreciated by only $2.2 \%$ against the dollar. The relative strengths of the pound and other convertible currencies on the international markets, and the fact that Ghanaian traders use more of those currencies for importation from Europe resulted in higher depreciation of the cedi against those currencies at 12.1 per cent and 10.7 per cent respectively.

The accumulation of international reserves in 2004 amounted to $\$ 1732$ million enough to cover 3.8 months of imports of goods and services, compared with 3.9 months in 2003, the fall being the result of higher projected rise in the value of imports.

External debt service declined in 2004. Actual debt service was $\$ 154.1$ million instead of the projected $\$ 440.8$, the savings of $\$ 286.7$ being total debt relief under the HIPC Initiative.

\subsubsection{Government Budget}

\section{Budget Deficit}

The overall budget deficit was equal to $3.2 \%$ of GDP exceeding the target of $1.7 \%$, but below the 2003 deficit of $3.4 \%$. Net domestic financing of the budget was equivalent to 
$0.5 \%$ of GDP and was higher than the programmed target of net repayment of $2.2 \%$ of GDP.

\section{Domestic Revenue Trends}

The growth of domestic revenue has been significant since 2000, exceeding 40\%, in 2001 with the exception of 2002 in which a lower growth of $27.6 \%$ was achieved. The growth doubled to $56.2 \%$ in 2003 . As a percentage of GDP, growth of domestic revenue has registered a smooth and steady growth since 2002, from 18\% to $21.2 \%$ of GDP in 2004 . The growth of domestic revenue has exceeded the rate of inflation, meaning improved real revenue generation.

\subsubsection{Trends in Domestic Debt}

The reduction in domestic debt which is an important policy objective of the GPRS has spillover effects on the various sectors of the economy, contributing partly to a reduction in inflation. The burden of domestic debt has been decreasing from a domestic debt/GDP ratio of $23.9 \%$ in 2002 to $18.3 \%$ in 2003 and $15.2 \%$ in 2004 .

The reduction in domestic debt has brought some relief to the private sector with an increase in credit to the sector. There was 31.3\% growth of credit in 2004 for all sectors with the exception of Electricity, Gas and Water registering positive growth rates.

The improvements in the macroeconomic situation and the easing of inflationary pressures have enabled the Monetary Policy Committee of the Bank of Ghana to revise downwards prime rates. The 91-day Treasury Bill rate declined from $18.71 \%$ at the end of 2003 to $17.08 \%$ at the end of 2004 . The commercial banks responded positively to the general pattern reducing their base rates from an average of $29 \%$ to $25.4 \%$ in 2004 .

\subsubsection{Real Agricultural Growth Rate}

The growth in GDP was propelled by outstanding performance of the agricultural sector with a $7.5 \%$ growth. This exceeded the $6.1 \%$ growth for 2003 . Agriculture contributed $46.7 \%$ of the $5.8 \%$ growth in GDP. The strong agricultural performance is attributed as in 2003 to the cocoa sub-sector which experienced an unprecedented $29.9 \%$ growth as a result of the mass spraying exercise and better husbandry practices initiated by government in 2001.

The non-cocoa sub-sector did not enjoy the same growth rates as cocoa but experienced rates not very different from what were achieved in 2003. In welfare terms the growth of the agricultural sector outpaced the growth of population.

\subsubsection{Real Food Crop/Per Capita Growth}

The performance of the food crop sector improved only marginally from 5.3\% in 2003 to $5.4 \%$ in 2004 . Thus the welfare changes in the sub-sector were negligible. Thus aside from cocoa, the modernisation programme of government did not make the desired impact. There is a need to intensify the irrigation programmes and improvements in seedlings for the food crop sector. 
With the growth in agriculture coming mainly from cocoa, incomes of cocoa farmers were expected to increase in 2004 , contributing substantially to poverty reduction in the cocoa producing areas just as in 2003. Thus the distribution of benefits of the strong performance of the agricultural sector was skewed towards the cocoa producing areas, with poverty endemic areas still lagging behind.

\subsection{POVERTY REDUCTION IMPACT OF GROWTH AND GOVERNMENT POVERTY SPENDING}

Data on the impact of increased government spending on poverty reduction programmes and effects on economic growth and macroeconomic stability is not easily available.

However, CWIQ data of 1997 and 2003 and NDPC Citizens Report Card Survey undertaken in August 2004 of five selected districts give indication of reduction in poverty between 1997 and 2003 and mixed perception of impact of macroeconomic stability and increased government spending on welfare.

\subsection{MACROECONOMIC STABILITY POLICY DEVELOPMENTS}

Government and Development Partners have agreed on a number of macroeconomic measures which fall under the following policy objectives and serve as a reference point to assess progress towards attaining macroeconomic stability.

The objectives for attaining Macroeconomic Stability are:

- Reduce and restructure the domestic debt

- Improve Public Expenditure Management

- Improve fiscal resource mobilization

- Pursue price and exchange rate stability

- Develop financial sector

Table 4.6 provides a summary of the policy objectives and the various measures adopted to achieve macroeconomic stability

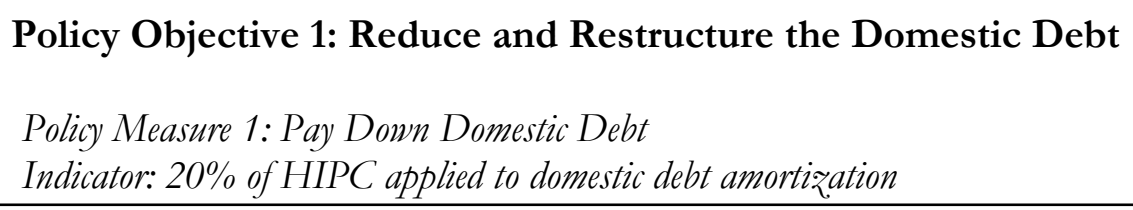

The principal objective of fiscal policy has been to reduce and stabilise domestic debt. This creates room for private sector credit and reduces the crowding out of the private sector.

Several activities were undertaken by government to reduce and restructure domestic debt including paying down domestic debt and developing medium and long-term instruments. 
Status:

By the end of 2004 the Government had disbursed an amount of $\notin 1,816.8$ billion of HIPC funds, out which $₫ 301.4$ billion was used to repay domestic debt, constituting $16.4 \%$ of HIPC funds.

Policy Measure 2: Development of Medium and Long Term Instruments

Indicator: Number of medium to long-term instruments developed

Status:

With regard to restructuring the domestic debt the Government issued Medium Term Bonds: 2-3 year Floating Rate Notes with the interest rates tied to Treasury Bill interest rates and 2-3 Year Fixed Rate Notes. The objective of the new debt instruments is to promote and develop the bond market. It is expected that the new securities will lengthen the average maturity of government domestic debt and reduce concentration in specific maturities.

\section{Policy Objective 2: Improving Public Expenditure Management}

Policy Measure: Review, refinance and strengthen implementation of MTEF and PUFMARP

(a) Modernise PEM regulatory framework

Policy measure 1: Within the context of existing legislation, develop guidelines and procedures for more comprehensive collation of annual financial accounts comprised of:

- Consolidated Fund

- Statutory Funds

- Donor Funded Sector

- Project/Program Funds

As part of the process of modernising the PEM Regulatory Framework, the Financial Administration Regulations, 2004, LI 1802 for the Financial Administration Act, 2003 was passed by Parliament in August 2004.

Following the passage of the three Public Financial Management laws - the Financial Administration Act, 2003 (Act 654), the Internal Audit Agency Act, 2003 (Act 658), and the Public Procurement Act, 2003 (Act 663), to operationalise the laws the MFEP conducted a nationwide educational and awareness programme for over 10,000 people drawn from the Executive (including the President and his Ministers), Public and Private Sectors and Development Partners from March 2004 to December 2004.

(b) Strengthen budget formulation

Policy measure 1: Deepen alignment of functional classification of the budget with GFS, with a view to simplifying budget format and reporting

To strengthen budget formulation the summary expenditure reports as at $31^{\text {st }}$ May 2004 were prepared on the basis of both the conventional and Government Financial Statistics (GFS) format and circulated to all line Ministries on regular basis.

The PUFMARP continued to make significant progress in the implementation of the various components in the Ministry of Finance and Economic Planning and Controller 
and Accountant-General's Department. In addition, BPEMS was set up at the following MDAs where hands on training were provided.

- Ministry of Health;

- Ghana Health Service;

- Ministry of Interior (Headquarters);

- Ministry of Education Youth \& Sports;

- Ghana Education Service (Headquarters); and

- Ministry of Roads \& Transport Headquarters

However, there is a problem with network connectivity linking the MDAs.

(c) Strengthen budget execution and reporting

Policy measure 1: Establish Internal Audit Agency Secretariat and begin process of staffing existing Internal Audit positions in $M D A$ s and $M M D A s$

Policy measure 2: Create and staff Internal Audit Units in MDAs and MMDAs currently without such Units

Policy measure 3: Auditor-General to submit 2003 audited accounts on the Consolidated Fund and MDAs

To strengthen budget execution and reporting the government was required to establish Internal Audit Agency secretariat and begin process of staffing existing internal audit positions in MDAs and MMDAs. To achieve this, the Public Procurement and the Internal Audit Agency Boards were inaugurated in August 2004. Both Boards, with the overall responsibility of ensuring that structures that would complement Government's efforts at ensuring value for money in Government expenditure, worked with public institutions to establish procurement structures at the Ministerial and Regional levels; and initiate the process of absorbing internal audit staff of Controller and Accountant General's Department into their various organizations, while those without Internal Audit Units began the process of establishing and recruiting staff for the units.

Interim Secretariats were set up for both Boards while the Boards initiated the process of establishing their permanent Secretariats. Three-Year Strategic Plans, which will guide the operations of the Boards, have been drawn up by each of the Boards.

The Public Procurement Board collaborated with international organisations to develop an international benchmarking, monitoring and evaluation tools which have been trial tested in a number of public institutions in the country.

There were several interactions between the Public Procurement Board and procurement entities especially with State Owned Enterprises and large MDAs in areas of establishing structures and ensuring that government gets value for money as well directives on sole sourcing and restricted tendering.

To further improve upon the decision making process in the area of domestic debt management, a Domestic Debt Management Unit was created in the MOFEP with the responsibility for forecasting Cash and Public Sector Borrowing Requirement (PSBR), introducing new securities to replace maturing GoG Index-linked Bonds, and building a comprehensive domestic database to facilitate formulation of domestic debt policies and strategies. 
In 2004, an enhanced cash management system was put in place for monthly cash releases 2003 Audit Reports on Consolidated Fund and on MDAs submitted to Parliament.

\section{Policy Objective 3: Improve Fiscal Resource Mobilization \\ Policy measure 1: Strengthen revenue collection institutions for tax collection \\ Policy measure 2: Improve collection of non-tax revenues.}

In 2004 Non-Tax Revenue lodgements recorded significant increases, and constituted $5.6 \%$ of domestic revenue which exceeded the target of 3\%. To achieve this objective the government carried out a number of activities including the following:

- Introduction of a Dividend Policy to guide State Owned Enterprises and Joint Venture companies in the declaration of dividends which resulted in an increase in dividend payment by $286.2 \%$ to Government;

- Release of $\notin 11.5$ billion to $18 \mathrm{MDAs}$ to implement revenue enhancement measures;

- Embarking on an exercise with the Security Agencies to track illegal operators (in 10 MDAs) behind forgery and duplication of Value Books to curtail revenue leakages. Twenty five (25) illegal operators have so far been prosecuted;

\section{Policy Objective 4: Pursue Price and Exchange Rate Policy}

The Monetary Policy Committee of the Bank of Ghana which was established in 2003 continued to use monetary policy instruments, particularly the prime rate, to influence inflationary expectations and sterilisation of excess liquidity.

Interest rates generally followed the declining pattern of 2003. Following the improvements in the macroeconomic situation in 2004, the Monetary Policy Committee revised downwards by 150 basis points from 21.5 percent to 20.0 percent in February 2004. Sustained improvements in economic performance led to further reductions in the rate and finally stabilising at $18.3 \%$ by December 2004 .

Policies which improved foreign exchange liquidity, policies of fiscal discipline and prudent monetary programme accounted for the stability of the cedi against the dollar and other major currencies.

\section{Policy Objective 5: Create a More Diversified Financial Sector}

Policy Measure: Create a more diversified financial sector and improve access to financial service

Implement FINSSP, including:

- improving the administrative framework for micro finance,

- establishment of a Central Securities Depository for government securities; and

- the enactment of Long Term Savings law for private pension and housing Schemes.

The following activities were undertaken in 2004 to reform and diversify the financial sector:

- Implementation of FINSSP, including improving the administrative framework for micro finance. Nomination of Board Members and recommendations for appointment of Chief Executive Officer of Microfinance Centre forwarded to the 
President for approval. A list of all current interventions to support Microfinance activities in Ghana is prepared. In the interim, a four member technical committee together with stakeholder beneficiaries are performing the services of the Center pending the appointment of the Board and formal staffing of the Center

- The Central Settlement and Depository System (CSDS) which is a trading platform for financial instruments, was made operational initially for government securities to further enhance confidence in market participants and to facilitate and modernize security trading;

- The Venture Capital Fund Bill was passed. The Venture Capital Fund is to address inadequate capital problems of the private sector especially, the Micro, Small and Medium Enterprises (MSME)

- Parliament has enacted the Long term Savings Law for private pension and housing schemes; the LTS Law is to deepen savings mobilisation for the economy as well as to broaden retirement options for Ghanaian workers;

- To strengthen the financial market infrastructure and to enhance transparency, Government separated Open Market Operations (OMO) of Bank of Ghana from Public Sector Borrowing Requirement (PSBR). This assisted in determining actual borrowing needs of government resulting in the reduction of government borrowing and hence achieving the objective of "crowding in" of the private sector;

- Continuous capacity development and training programmes in Microfinance were also organized for ARB APEX Bank and related institutions under GHAMFIN to facilitate the delivery of financial services for the MSMEs and the rural economy.

\section{Policy Recommendations}

- The government has succeeded in achieving some of its objectives of macroeconomic stability, such as economic growth. The economy is still vulnerable to exogenous shocks. Continued progress will require improving upon the mediumterm macroeconomic objectives set out in the GPRS, such as economic growth, external stability, reduction in the domestic debt, reduction of inflation to single digits, increasing revenue mobilization, curtailing deficit financing by pursuing a policy of zero net domestic financing.

- Macroeconomic policy has concentrated on achieving macroeconomic stability. It should now aim at simultaneously achieving macroeconomic stability, economic growth and poverty reduction.

- To achieve per capita income of $\$ 1000$ by 2015 would require sustained growth rates of about $6 \%$. The government will pursue more ambitious growth policies that will propel the economy into an accelerated growth mode.

- Growth of the economy is over dependent on agriculture, especially cocoa. While food crop including harnessing the country's agricultural resource potential through value addition and the application of science and technology. Government will also focus on potential high growth sectors such as tourism, trade and ICT.

- Real government spending especially in areas which support production such as infrastructure will need to be increased. This will have to be financed in a noninflationary way by strengthening resource mobilization through

- the strengthening of the revenue collection machinery (IRS and VAT Secretariat)

- expanding the tax net to cover small businesses and the informal sector, and 
- improving non-tax revenue generation, such as requiring State-owned enterprises pay reasonable dividend; some of these enterprises operate as if they belong to management.

- Reduce the domestic debt stock with the goal of encouraging private investment, while accelerating public sector reforms. While the GPRS targets halving the domestic debt/GDP ratio by the end of 2005 down from 26 percent in 2000, further reductions to a ratio of below $10 \%$ will be needed to improve credit to the private sector and in the fight towards single digit inflation.

- A number of measures have been undertaken to reform public expenditure management that have enhanced the transparency and accountability of government outlays. There are still weaknesses in the system. The government will take steps to address these weaknesses.

- There have been problems with the operation of the BPEMS. The objective of government in 2005-06 will be to make the BPEMS work.

- The goal of monetary policy will continue to focus on reducing the rate of inflation towards single digits. The BOG will use open market operations and adjustments to the prime rate to achieve this objective. While recognizing the need for price stability, the Bank will look at the perceived trade-off between inflation and growth. There is the need to conduct a study to determine the optimal level of inflation. For the Ghanaian economy the optimal rate might be higher than the single digit target rate that the government is pursuing.

- The current large interest rate spread that limits the private sector's access to capital need to be lowered. This will be achieved through fiscal policy, stepped up bank supervision and the reduction in the secondary reserve requirements for banks.

- The inflation rate is linked to petroleum pricing. Deregulating the petroleum sector to open up to private sector investment and activity and establishing a pricing regime that will be devoid of government influence while credibly and effectively isolating government from decisions relating to the determination of petroleum prices, except for taxes.

- Government will continue to dialogue effectively with the development partners through the Multi-Donor Budget Support Framework to improve on the quantum of support and on the disbursement of their pledges to support the budget in the implementation of the GPRS.

- Refinements will be made to the GPRS to pursue poverty reduction strategies while at the same time pursuing the objective of achieving the $\$ 1000$ per capita income target.

- Government spending generally reflected the GPRS priorities and there is a strong linkage of the budget to the medium term development policy framework. However these expenditures as published do not clearly show the extent to which the poor benefited, especially the deprived areas of Northern, Upper east and Upper West and Central Regions. A more detailed breakdown of spending will be provided to forge a closer link between budget allocations and beneficiary targets.

- While the pursuance of the growth objective will lead to reductions in poverty, activities related to poverty reduction will need to be allocated additional resources. There are competing demands for government resources; government will thus strive to expand the resource envelope.

- In order to reduce the vulnerability of the economy to exogenous shocks, external sector policy will pursue the diversification of export earnings and the accumulation of foreign exchange reserves in the medium term. 
- The unemployment rate is a critical macroeconomic indicator of welfare. But information on the unemployment rate which is regularly reported in other countries is not available. Government will work hard to ensure that labour market information be made available more frequently.

- There is a need for the development of a Ghana macroeconomic database (jointly by the GSS, MOFEP, BOG) that is accessible by all MDAs and DPs. 
Table 4.6: Policy Objectives of MTP, PRSC/MDBS

\begin{tabular}{|c|c|c|c|c|c|c|}
\hline $\begin{array}{l}\text { Policy } \\
\text { Objective }\end{array}$ & $\begin{array}{l}\text { MEASURE/ACTIVI } \\
\text { TY/TRIGGERS }\end{array}$ & INDICATOR & 2002 STATUS & 2003 STATUS & 2004 STATUS & PROGRESS \\
\hline \multicolumn{7}{|l|}{ MTP } \\
\hline \multirow{2}{*}{$\begin{array}{l}\text { Reduce and } \\
\text { Restructure } \\
\text { domestic debt }\end{array}$} & Pay down domestic debt & $20 \%$ of HIPC Funds & $\begin{array}{l}\text { c81.4 billion applied to } \\
\text { domestic debt }\end{array}$ & $\begin{array}{l}\not 144 \text { billion was paid to reduce } \\
\text { domestic debt }\end{array}$ & $\begin{array}{l}\not 301.4 \text { billion was used to } \\
\text { repay domestic debt. }\end{array}$ & \\
\hline & $\begin{array}{l}\text { Develop medium and long } \\
\text { term instruments }\end{array}$ & $\begin{array}{l}\text { Number of } \text { medium } \\
\text { to long r term } \\
\text { instruments developed }\end{array}$ & $\begin{array}{l}\text { GILB, Cocoa Bill } \\
\text { introduced }\end{array}$ & $\begin{array}{l}\text { GoG index linked bond Cocoa } \\
\text { Bills continued }\end{array}$ & $\begin{array}{l}\text { Government } \text { issued } \\
\text { Medium Term Bonds: 2-3 } \\
\text { Year Fixed and Floating } \\
\text { rate bonds }\end{array}$ & \\
\hline $\begin{array}{l}\text { Improve Public } \\
\text { Expenditure } \\
\text { Management }\end{array}$ & $\begin{array}{l}\text { Review, refinance and } \\
\text { strengthen implementation } \\
\text { of MTEF and PUFMARP }\end{array}$ & $\begin{array}{l}\text { Revenue allocated to } \\
\text { financing MTEP and } \\
\text { PUFMARP }\end{array}$ & $\begin{array}{l}\$ 37.224 \text { million allocated } \\
\text { to funding PUFMARP I, } \\
\text { of which approx. } \$ 29.114 \\
\text { million has been } \\
\text { disbursed and the } \\
\text { remaining } \$ 8.11 \text { million } \\
\text { as outstanding. The } \\
\text { funding sources were: } \\
\text { DFID, CIDA, EU, IDA } \\
\text { and GoG }\end{array}$ & $\begin{array}{l}\text { Financial information project } \\
\text { that will house the BPEMS } \\
\text { operating system is } 65 \% \\
\text { completed due to lack of funds }\end{array}$ & & \\
\hline
\end{tabular}

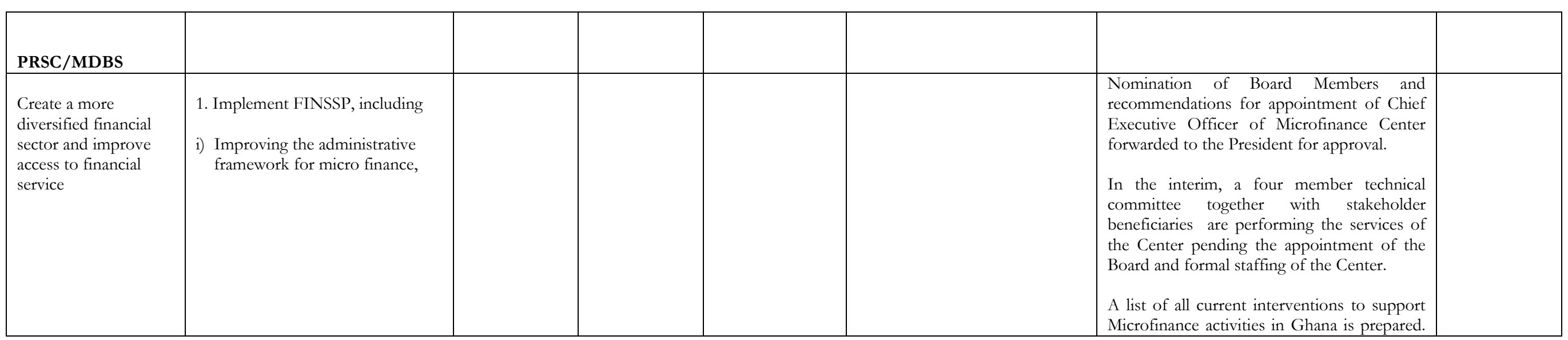




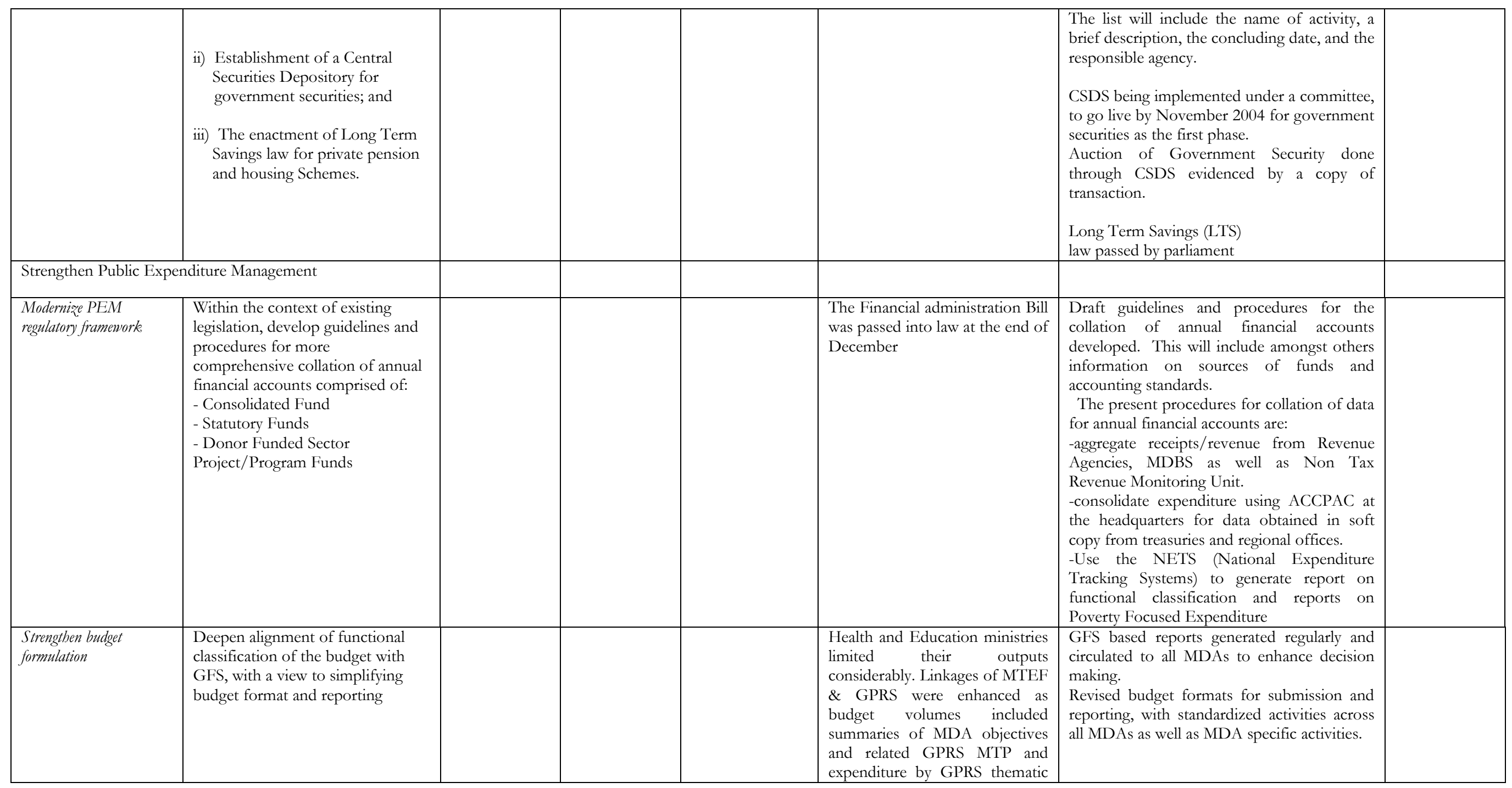




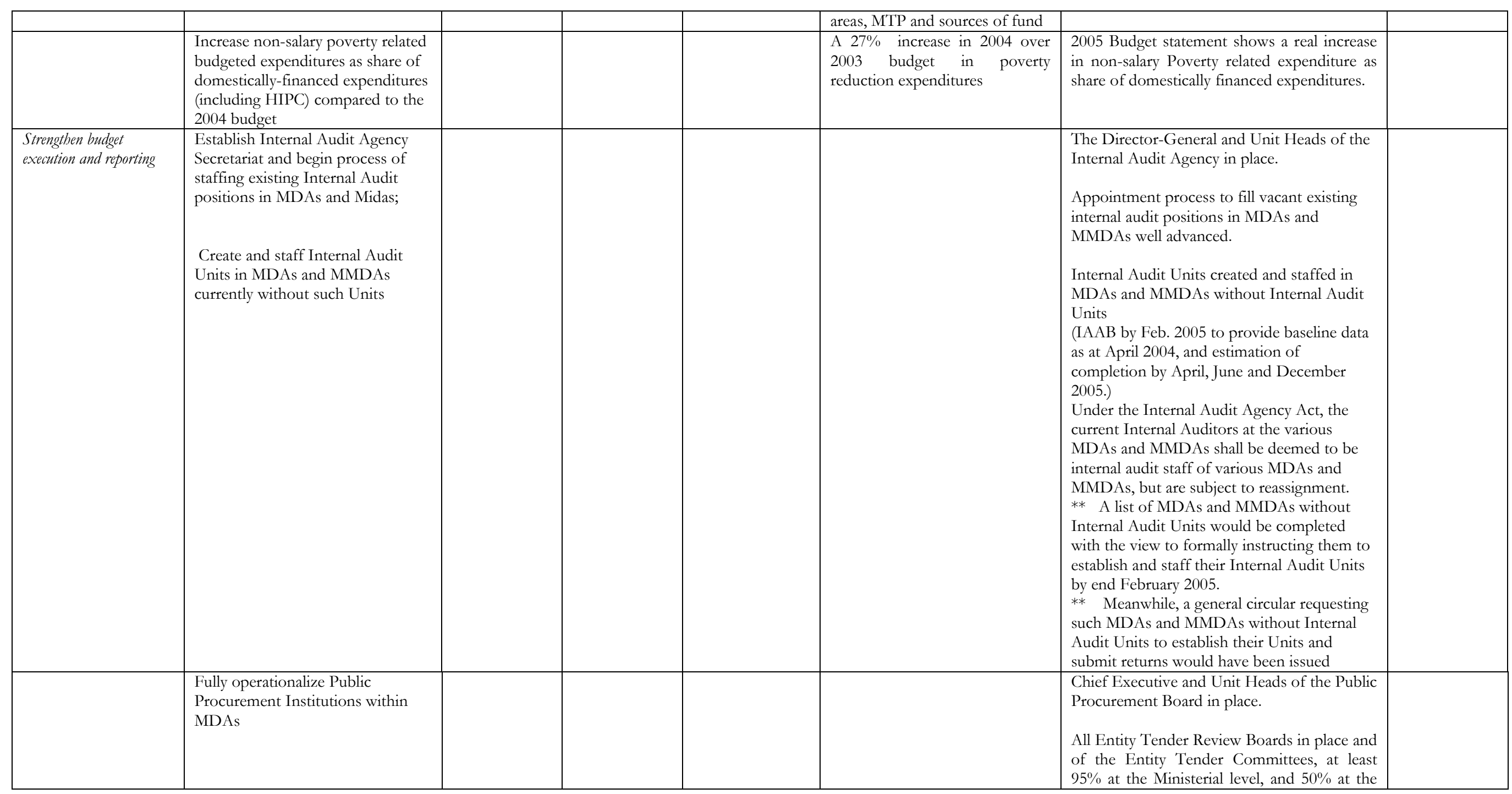




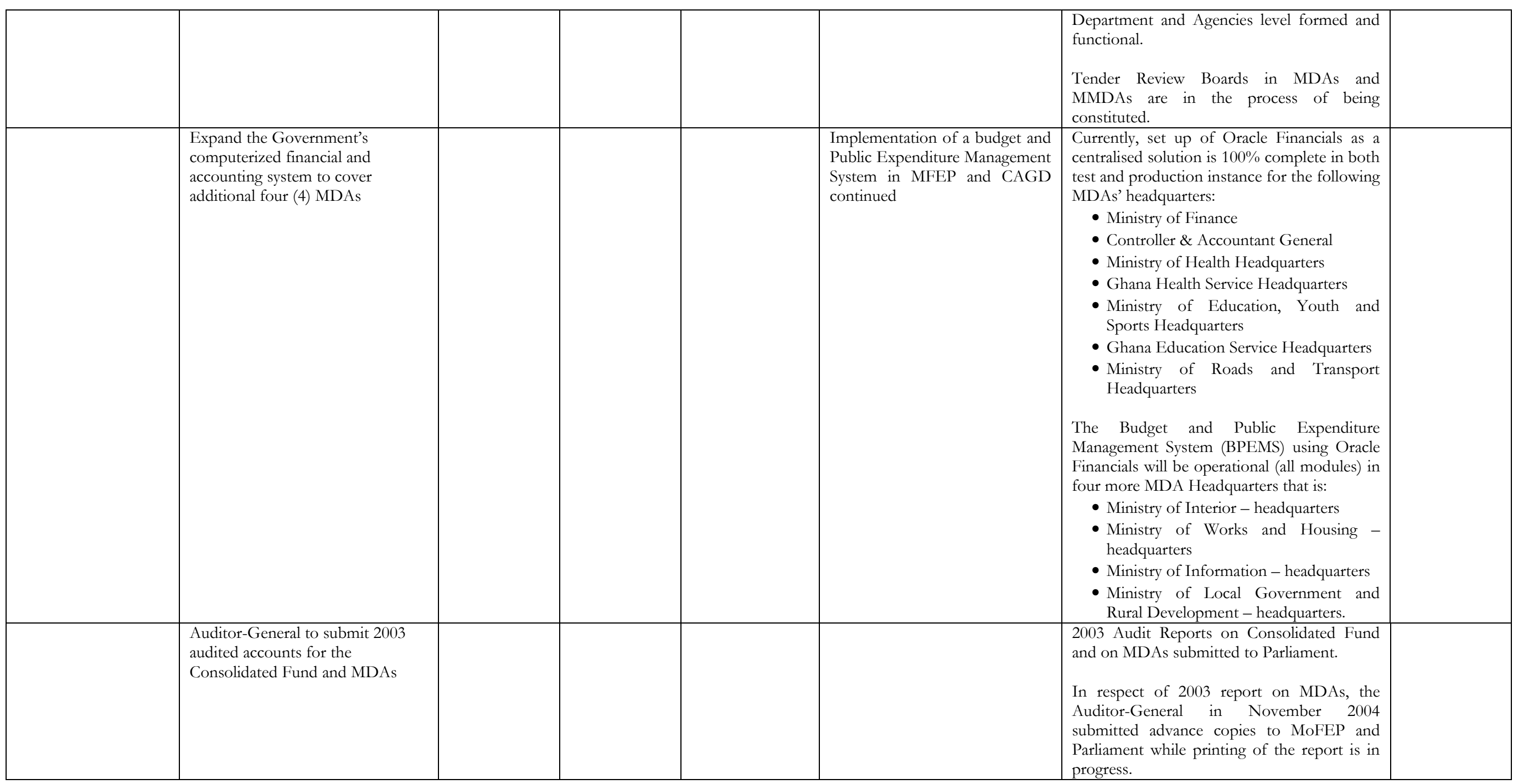




\section{CHAPTER FIVE}

\section{PRODUCTION AND GAINFUL EMPLOYMENT}

\subsection{INTRODUCTION}

The strategy to improve production and gainful employment seeks to create an enabling environment to stimulate private sector participation. In that regard policy is focused on four key areas namely:

- the development of the rural economy through the modernisation of agriculture;

- sustained environmental protection through re-afforestation;

- enhanced infrastructure development and;

- creating an enabling environment for private sector activities and development.

\subsection{REVIEW OF 2003 APR POLICY RECOMMENDATIONS}

Progress on the implementation of policy recommendations made in the 2003 APR is presented below in Table 5.1

Table 5.1: Status of implementation of 2003 APR Recommendations

\begin{tabular}{|c|c|}
\hline 2003 APR Policy Recommendations & Status in 2004 \\
\hline $\begin{array}{l}\text { Crop production is largely rain-fed and traditional } \\
\text { farming techniques still dominate. To improve } \\
\text { production the Government will encourage } \\
\text { private commercial farming based on proper } \\
\text { mechanized and irrigation systems. }\end{array}$ & $\begin{array}{l}\text { Significant progress was recorded particularly } \\
\text { with the importation of equipment and } \\
\text { machinery by government for sale to the private } \\
\text { sector. Progress with respect to irrigation } \\
\text { attributable to the formal sector has been } \\
\text { sluggish although the informal / private sector } \\
\text { recorded improvement. There has also been an } \\
\text { improved participation of NGOs especially in } \\
\text { the Northern regions. }\end{array}$ \\
\hline $\begin{array}{l}\text { The Ministry of Trade, Industry and PSI will } \\
\text { encourage the establishment of industrial estates } \\
\text { emphasizing agricultural machinery development. }\end{array}$ & $\begin{array}{l}\text { Some progress has been made with respect to the } \\
\text { establishment of industrial estates. For instance } \\
\text { under the PSI farmer operations for the } \\
\text { establishment of two new starch factories began } \\
\text { at Koforidua and Obuasi. }\end{array}$ \\
\hline $\begin{array}{l}\text { There will be an intensification of infrastructural } \\
\text { development, especially in feeder roads } \\
\text { rehabilitation, construction and maintenance to } \\
\text { provide market access to rural agriculture. }\end{array}$ & $\begin{array}{l}\text { Length of engineered feeder road increased. The } \\
\text { road condition matrix increased from } 29-26-45 \text { in } \\
2001 \text { to } 46-25-29 \text { in } 2004 \text { for good-fair-bad roads } \\
\text { respectively }\end{array}$ \\
\hline $\begin{array}{l}\text { For the re-afforestation of degraded lands will be } \\
\text { an early commencement of the Phase II of the } \\
\text { Natural Resource Management Programme at the } \\
\text { Ministry of Lands and Forestry. }\end{array}$ & $\begin{array}{l}\text { An appreciable progress has been recorded in the } \\
\text { plantation development }\end{array}$ \\
\hline $\begin{array}{l}\text { With the detachment of the Ministry of Mines } \\
\text { from Energy, the Government will assess the } \\
\text { feasibility of using a percentage of the Mineral } \\
\text { Development Fund as seed money outside GoG } \\
\text { expenditures to finance poverty reduction } \\
\text { projects and the Ministry's activities will be } \\
\text { highlighted in the GPRS update. }\end{array}$ & $\mathrm{N} / \mathrm{A}$ \\
\hline The activities of the Ministry of Tourism are not & One policy objective is to promote tourisn \\
\hline
\end{tabular}




\begin{tabular}{|l|l|}
\hline $\begin{array}{l}\text { fully captured in the GPRS and will be fully } \\
\text { integrated in the GPRS during the update for the } \\
2006-2008 .\end{array}$ & $\begin{array}{l}\text { major source of domestic revenue while } \\
\text { preserving our culture and the environment }\end{array}$ \\
\hline $\begin{array}{l}\text { The Ministry of Food and Agriculture captures } \\
\text { data for only food crops. There is a need to } \\
\text { expand the coverage of the Annual survey to } \\
\text { include non-food crops. The capacity to capture } \\
\text { additional data is required. }\end{array}$ & No progress \\
\hline $\begin{array}{l}\text { In the area of processing agricultural produce, the } \\
\text { Ministry of Trade, Industry and Presidential }\end{array}$ & $\begin{array}{l}\text { Some progress has been made. Sensitization } \\
\text { workshops on the REDP were held in all } 110\end{array}$ \\
$\begin{array}{l}\text { Initiative has not achieved much. The emphasis } \\
\text { has now being shifted to the Rural Enterprise }\end{array}$ & $\begin{array}{l}\text { districts. 87 draft business plans were prepared } \\
\text { and } 57 \text { were finalized for implementation }\end{array}$ \\
$\begin{array}{l}\text { Development Programme, which involves the } \\
\text { establishment of three enterprises each in the 110 } \\
\text { districts }\end{array}$ & \\
\hline
\end{tabular}

\subsection{OUTCOME AND IMPACT INDICATORS}

Table 1.A in the Appendix presents a summary of the status of indicators monitored under each of the four Medium Term Priority areas as well as implementation status of the activities/actions/triggers captured in the PRSC-3 / MDBS 2005.

\subsubsection{Modernised Agriculture}

There five policy objectives under modernised agriculture are:

- Ensuring Food Security

- Rehabilitation of the Fisheries Sector

- Provision of Irrigation Facilities

- Increased Mechanization of Agriculture; and

- Improved Non-Farm Rural Incomes.

A total of fifteen indicators were selected for tracking the status of the five policy objectives under modernised agriculture.

\section{Policy Objective: Ensuring Food Security}

\section{Achievements/Outcomes of Indicators}

There have been some improvements in indicator status under this policy objective as summarised in Table 5.2. The indicators that saw some improvements include the percentage of post harvest losses and the number of farmers served by one extension officer. 
Table 5.2: Summary of Food Security Indicators Achievements (2003 - 2004)

\begin{tabular}{|c|c|c|c|c|c|}
\hline $\begin{array}{l}\text { Policy } \\
\text { Objective }\end{array}$ & Indicators & Targets & $\begin{array}{c}\text { Indicator Level } \\
2003\end{array}$ & $\begin{array}{c}\text { Indicator } \\
\text { Status } 2004\end{array}$ & Progress \\
\hline \multirow[t]{3}{*}{$\begin{array}{l}\text { Ensure } \\
\text { Food } \\
\text { Security }\end{array}$} & $\begin{array}{l}\text { Percentage Post } \\
\text { Harvest Losses }\end{array}$ & $15-20 \%$ & $\begin{array}{l}20-25 \% \text { (cereals) } \\
35-38 \% \text { (perishables) }\end{array}$ & $\begin{array}{l}15-20 \% \\
33-35 \%\end{array}$ & $\begin{array}{l}\text { Target achieved } \\
\text { for cereals } \\
\text { Modest } \\
\text { progress } \\
\text { made on } \\
\text { perishables }\end{array}$ \\
\hline & $\begin{array}{l}\text { Tons of food } \\
\text { crops } \\
\text { produced }\end{array}$ & $\mathrm{N} / \mathrm{A}$ & $\begin{array}{l}\text { Maize }=1.29 \mathrm{~m} \mathrm{Mt} \\
\text { Rice }=0.239 \mathrm{~m} \mathrm{Mt} \\
\text { Millet }=0.176 \mathrm{~m} \mathrm{Mt} \\
\text { Sorghum }=0.338 \mathrm{~m} \mathrm{Mt} \\
\text { Cassava }=10.2 \mathrm{~m} \mathrm{Mt} \\
\text { Yam }=3.8 \mathrm{~m} \mathrm{Mt} \\
\text { Plantain }=2.3 \mathrm{~m} \mathrm{Mt}\end{array}$ & $\begin{array}{l}\text { Maize }=1.16 \mathrm{~m} \mathrm{Mt} \\
\text { Rice }=0.242 \mathrm{~m} \mathrm{Mt} \\
\text { Millet }=0.144 \mathrm{~m} \mathrm{Mt} \\
\text { Sorghum }=0.287 \mathrm{~m} \mathrm{Mt} \\
\text { Cassava }=9.7 \mathrm{~m} \mathrm{Mt} \\
\text { Yam }=3.89 \mathrm{~m} \mathrm{Mt} \\
\text { Plantain }=2.38 \mathrm{~m} \mathrm{Mt}\end{array}$ & Mixed result \\
\hline & $\begin{array}{l}\text { Extension } \\
\text { Officer to } \\
\text { Farmer Ratio }\end{array}$ & $1: 1200$ & $1: 1,500$ & $1: 1,400$ & $\begin{array}{l}\text { The Ministry is } \\
\text { expected } \\
\text { to lower the } \\
\text { ratio to about } \\
1: 1,000 \text { in five } \\
\text { vears }\end{array}$ \\
\hline
\end{tabular}

Source: MOFA

Percentage Post Harvest Losses

The percentage of post harvest losses for cereals decreased considerably from the level of $20-25 \%$ in 2003 to $15-20 \%$ in 2004 and this equals the target level for 2005. Post harvest loss for perishables also experienced a marked improvement from the 2003 levels of 35$38 \%$ and $33-35 \%$ in 2004 .

Key policy measures introduced to reduce post harvest losses include the following: First the post harvest management unit, in collaboration with the National Post Harvest Working group gathered and put together information on technologies developed for maize, cassava, yam, plantain, citrus, tomato and fish. This was to form the basis of further research which will, in turn, be used as a reference manual for extension agents, NGOs and other stakeholders engaged in post-harvest management of agricultural commodities.

Furthermore, the Ministry of Food and Agriculture utilized its share of HIPC funding to support the procurement and distribution of selected agro-processing and storage equipment to farmers and other stakeholders. It is expected that these equipment will help farmers and other stakeholders to reduce post-harvest losses and add value to farm products. Details of the equipment purchased included:

口 40 complete lines of tomato processing facilities;

a 700 one-ton metallic silos;

\ 50 each of Mechanical Dryers, Solar Dryers, Rice Threshers, and Palm Fruit Digestors;

- 100 Multi-Crop threshers;

- 100 Cassava Grating Machines;

- 50 Single Screw Presses;

- 100 Double Screw Presses; and

口 50 sets of Shea Butter Processing Equipment 


\section{Tons of Food Crops Produced}

This indicator was a replacement of the earlier 'tons of silos established' because it presents a better picture of food security than the former. Generally there was a decline in the production of major crops as well as the cropped areas. The decline in production of some of the major crops was mainly a result of a reduction in the cropped areas as opposed to a decline in farm productivity as captured by yield per hectare. The crops that experienced the most significant declines, Millet (18.3\%), Sorghum (15\%) and groundnuts (11.3) are predominantly produced in the Northern, Upper East and Upper West regions.

\section{Extension Officer to Farmer Ratio.}

The ratio of extension officer to the number of farmers decreased from 1:1,500 in 2003 to about 1:1400 in 2004. This indicates an improvement as the reduction in the extension officer: farmer ratio means that fewer farmers now have access to the same extension officer. In other words an extension officer will have more time for each farmer.

It is important to note that the situation is expected to improve to $1: 1000$ with the implementation of the PRSC-3 / MDBS measure to engage 250 additional Extension Agents and 50 Agricultural graduates. This activity is on-going and with MOFEPs approval, MOFA has commenced the process of recruiting the 250 Agriculture Extension Agents (AEAs) and 50 agriculture graduates annually for the next five years. Successful candidates recruited were oriented and posted to various agricultural centres starting November 2004.

\section{Policy Objective: Rehabilitate the Fisheries Sub-sector}

\section{Achievements/Outcomes of Indicators}

There are four indicators under the policy objective of Rehabilitating the Fisheries Sector. Two out of the four indicators showed marked improvements in the year under review. These are the Number of Hatcheries Constructed and the Quantity of Fingerlings Produced per annum. Table 5.3 below indicates performance of the fisheries sub-sector indicators over the period under review

Table 5.3: Performance of Fisheries Sub-sector

\begin{tabular}{|l|c|c|c|c|c|}
\hline $\begin{array}{l}\text { Policy } \\
\text { Objective }\end{array}$ & Indicators & Targets & $\begin{array}{c}\text { Indicator } \\
\text { Level 2003 }\end{array}$ & $\begin{array}{c}\text { Indicator } \\
\text { Status 2004 }\end{array}$ & Progress \\
\hline & $\begin{array}{l}\text { Number of Hatcheries } \\
\text { constructed }\end{array}$ & 4 & 2 & nill & $\begin{array}{c}\text { No progress from } \\
\text { the public sector } \\
\text { initiatives }\end{array}$ \\
\cline { 2 - 6 } $\begin{array}{l}\text { Rehabilitating } \\
\text { the Fisheries } \\
\text { Sector }\end{array}$ & $\begin{array}{l}\text { Quantity of fingerlings } \\
\text { produced per annum }\end{array}$ & & 150,000 & $1,760,000$ & Good progress \\
\hline
\end{tabular}

Source: $M O F A$

\section{Number of Hatcheries Constructed}

There has been no progress in this indicator as no hatchery has been constructed in the year under review through a government program. It is however important to mention that 4 well established private hatcheries have been completed in 2004. This therefore represents an achievement of overall target of 4 hatcheries by the end of the GPRS 


\section{Quantity of Fingerlings Produced per annum}

There was a more than ten-fold increase in the quantity of fingerlings produced per annum - from a level of 150,000 in 2003, it increased to $1,760,000$ in 2004 . There was a drop though in the area under fish farm from 450ha in 2003 to about 112.3ha. The quantity of fish produced per unit area of pond per cycle did not show any improvement in 2004, compared to the level recorded for 2003.

\section{Policy Measures}

The focus of Government's policies in 2004 regarding the fisheries sub-sector was to control illegal fishing as well as reduce over-fishing from marine sources and the Volta Lake. In that regard one steel vessel was procured for the Monitoring, Control and Surveillance (MCS) Unit of the Fisheries Directorate for patrols on the Volta Lake and a Vessel Monitoring System (VMS) to track positions of fishing vessels by way of compliance monitoring was acquired. Additionally five nucleus commercial fish farms were established and twenty fish farmer associations were trained in fish and pond management.

\section{Policy Objective: Provision of Irrigation Facilities}

Achievements/Outcomes of Indicators

Two indicators are considered under this policy objective. These are the proportion of arable land under irrigation and the number of dugouts constructed. Table 5.4 below shows the indicator levels for 2004

Table: 5.4: Provision of Irrigation Facilities

\begin{tabular}{|l|c|c|c|c|c|}
\hline $\begin{array}{l}\text { Policy } \\
\text { Objective }\end{array}$ & Indicators & Targets & $\begin{array}{c}\text { Indicator } \\
\text { Level } \\
\mathbf{2 0 0 3}\end{array}$ & $\begin{array}{c}\text { Indicator } \\
\text { Status 2004 }\end{array}$ & Progress \\
\hline $\begin{array}{l}\text { Provision of } \\
\text { Irrigation } \\
\text { Facilities }\end{array}$ & $\begin{array}{c}\text { Percentage of } \\
\text { arable land } \\
\text { under } \\
\text { irrigation }\end{array}$ & $\begin{array}{c}12 \% \\
(33,000 \\
\text { hectares })\end{array}$ & $\begin{array}{c}\text { estimated at } \\
0.08 \%\end{array}$ & nil & No progress \\
\cline { 2 - 6 } & $\begin{array}{c}\text { Number of } \\
\text { dugouts } \\
\text { constructed }\end{array}$ & 1,309 & 713 & 999 & $\begin{array}{c}286 \text { facilities have } \\
\text { been constructed in } \\
\text { 2004 alone }\end{array}$ \\
\hline
\end{tabular}

Source: MOFA

\section{Percentage of Arable Land under Irrigation}

A target of 33,000 hectares representing $12 \%$ of arable land is expected to be irrigated within the lifespan of the GPRS. About $0.08 \%$ of arable land has been irrigated since 2003. Although no government supported irrigation program has been implemented in 2004, available statistics showed that over 1,200 hectares of land has been undertaken through the informal / private sector interventions

\section{Number of Dugouts Constructed}

The number increased from 713 in 2003 to about 999 out of 1309 water facilities in 2004. Key policy initiatives that were undertaken to improve operational and cropping efficiency on existing irrigation projects as well as improving irrigable land include the following: 
- Development of a total of 31 irrigation schemes under the National Small Scale Irrigation Development Project Phase I. These interventions are at various stages of completion

- Twelve new dams were awarded on contract to bring to a total of 24 the Land Conservation and Smallholder Rehabilitation Project II (LACOSREP II). Designs for additional dams were also completed in 2004.

- The construction of eight dams, two dug-outs and twenty-two hand dug wells were completed under the Upper West Agricultural Development Project (UWADEP). Progress has also been made on five other dams and a dugout under the project.

- The completion of the Anum Valley and Mankessim Projects. This includes the supply of six pumps to each of the projects.

\section{Policy Objective: Increase Mechanisation of Agriculture}

Achievements/Outcomes of Indicators

This policy objective is monitored via four indicators namely: (i) Farmers' Access to Mechanized Tillage; (ii) Access to Harvesters; and (iii) Access to Processing Equipment and Tractor to Farmer ratio. With the exception of one indicator - Access to Harvesters which did not record any progress, all other indicators showed remarkable improvements. Table 5.4 shows the performance of indicators for 2003 and 2004

Table 5.5: Mechanized Agriculture Indicator Achievements (2003 - 2004)

\begin{tabular}{|l|l|c|c|c|c|}
\hline $\begin{array}{l}\text { Policy } \\
\text { Objective }\end{array}$ & Indicators & $\begin{array}{c}\text { Targets } \\
\text { Level } \\
\mathbf{2 0 0 3}\end{array}$ & $\begin{array}{c}\text { Indicator } \\
\text { Status 2004 }\end{array}$ & Progress \\
\hline $\begin{array}{l}\text { Increase } \\
\text { Mechanization } \\
\text { In Agric }\end{array}$ & $\begin{array}{l}\text { Farmer Access to } \\
\text { mechanized tillage }\end{array}$ & $15 \%$ & $8 \%$ & $12 \%$ & On Track \\
\cline { 2 - 6 } & Access to harvesters & $5 \%$ & $2 \%$ & $2 \%$ & No progress \\
\cline { 2 - 6 } & $\begin{array}{l}\text { Access to } \\
\text { processing } \\
\text { equipment }\end{array}$ & $30 \%$ & $24 \%$ & $42 \%$ & $\begin{array}{c}\text { Target } \\
\text { exceeded }\end{array}$ \\
\cline { 2 - 6 } & $\begin{array}{l}\text { Tractor to farmer } \\
\text { ratio }\end{array}$ & $1: 90,000$ & $1: 150,000$ & $1: 120,000$ & On track \\
\hline
\end{tabular}

Source: $M O F A$

Farmer Access to Mechanized Tillage

This indicator recorded an increase from the 2003 level of 8 percent to 12 percent in 2004 thus indicating that progress towards the achievement of the target of $15 \%$ is on track.

\section{Access to Processing Equipment}

The indicator status showed an increase from the 2003 level of $24 \%$ to $42 \%$ in 2004 thus exceeding the target of $30 \%$ by over $12 \%$.

\section{Tractor to Farmer Ratio}

There was a marked improvement in the tractor to farmer ratio in 2004. The ratio recorded a decrease from the 2003 level of 150,000 to 120,000 in 2004 indicating that farmers have access to more tractors. It is not surprising that the tractor to farmer ratio and farmer access to Mechanised Tillage indicators co-moved. As fewer farmers now have to use one tractor, it is expected that the proportion of farmers with Access to Mechanised Tillage will improve. 


\section{Policy Measures}

Key policy measures that accounted for the improvement in farmers' access to mechanized tillage included the following:

About 200 farm tractors with matching implements (in knocked down form) imported with HIPC resources were assembled locally and distributed to farmers all over the country. Eight hundred (800) additional tractors were programmed to be imported in 2004 with an Indian Exim Bank facility. Parliamentary approval was also given for the procurement of about 1,400 tractors for distribution to farmers.

\section{Policy Objective: Improve Farm and non-Farm growth in the Rural Sector}

This policy objective is derived from the PRSC-3 and the MDBS 2005. Measures/ activities designed to achieve the expected target of $2 \%$ annual increase in real per capita food production are to be found in MoFA's strategic plan (focusing on the elements with poverty focus and GoG agreed recommendations of the PSIA and other analytical studies)

\section{Achievements}

Key achievements recorded in 2004 towards improving farm and non-farm growth in the rural sector include the following:

- MOFA continued to implement the reviewed and costed Strategic Plan for 20042006. The cost centres prepared their annual work plans and budget for the year 2004. Implementations of planned activities are on-going with the release of the second and third quarter funds to the cost centres.

- MOFA also formed a multi-disciplinary committee including policy advisors which initiated activities to identify the poverty-focused recommendations in the PSIA for modernization of agriculture incorporation in the strategic plan.

- Detailed schedule of activities have been developed to review FASDEP. The first draft of the reviewed FASDEP is expected to be ready by the end of July 2005.

- MoFA has commenced the process of recruiting 250 Agriculture Extension Agents (AEAs) and 50 agriculture graduates annually for the next five years. The recruitment will help to improve the Agricultural Extension Agent/Farmer ratio from the current level of 1:1400 to 1:1000 for a more efficient extension service delivery. Successful candidates recruited in 2004 were trained and posted to various agricultural centres starting November 2004.

- MoFA's decentralization programme has been reviewed and the implementation of recommendations is on-going. A draft handbook on roles and responsibilities of MoFA staff positions has been prepared.

- Change Facilitators for Change Management Process in MoFA has completed two of three training modules.

\section{Policy Recommendations}

Even though most of the indicators in the agriculture sector have recorded some level of progress, there is the need for government to institute measures to arrest the decline in cropped areas as experienced in 2004. This will require a combination of factors among which are turning the apparent increase in irrigation activities into deliverables. In other words the increased number of dugouts should translate into significant increases in the area under irrigation. It is also important that agriculture extension services are made 
more efficient so that policy measures such as those to increase mechanization and irrigation can effectively complement each other

Major interventions in agriculture would include the provision of improved technological packages and support services to farmers and other operators in the sector. The broad policy intervention will also attract the youth into agriculture and further increase productivity and add value to farm produce. This would lead to an improvement in incomes of farmers as well as ensure a quantum leap in the development of the sector.

\subsubsection{Sustained Environmental Protection through Re-afforestation}

Environmental protection through reforestation as an important ingredient for sustained development. This is particularly the case as most of the primary economic activities (agriculture, mining and infrastructure development) needed to generate increased production and gainful employment has implications for the environment. The policy objectives are reforestation and land administration with six and five indicators respectively.

\section{Policy Objective: Increase Environmental Protection through Reforestation} Achievements/Outcomes of Indicators

Good progress has been made with respect to three of the six indicators. Table 5.6 below shows the level of progress under the indicators.

Table 5.6: Reforestation Indicator Achievements (2003 - 2004)

\begin{tabular}{|c|c|c|c|c|c|}
\hline $\begin{array}{l}\text { Policy } \\
\text { Objective }\end{array}$ & Indicators & Targets & $\begin{array}{c}\text { Indicator } \\
\text { Level } \\
2003 \\
\end{array}$ & $\begin{array}{c}\text { Indicator } \\
\text { Status } 2004\end{array}$ & Progress \\
\hline \multirow{6}{*}{$\begin{array}{l}\text { Increase } \\
\text { Environment } \\
\text { al } \\
\text { Protection } \\
\text { Through } \\
\text { Reforestation }\end{array}$} & No of hectares planted & $\begin{array}{l}40,000 \mathrm{ha} \\
\text { by } 2008\end{array}$ & 30,326ha & 28,400 in 2004 only & $\begin{array}{l}\text { Target } \\
\text { exceeded }\end{array}$ \\
\hline & Rate of deforestation & & $\begin{array}{l}50,000 \text { per } \\
\text { year }\end{array}$ & $\begin{array}{l}\text { Less than 50,000 } \\
\text { (yet to be } \\
\text { determined - } \\
\text { measured every } 10 \\
\text { Years.) }\end{array}$ & $\begin{array}{l}\text { Some } \\
\text { Progress }\end{array}$ \\
\hline & $\begin{array}{c}\text { Number of CRMAS* } \\
\text { established }\end{array}$ & 2 & 1 & nil & No progress \\
\hline & $\begin{array}{c}\text { Ha of urban areas } \\
\text { Planted }\end{array}$ & $\begin{array}{l}20,000 \text { ha } \\
\text { by } 2008\end{array}$ & 1300ha & 1,350ha & On track \\
\hline & $\begin{array}{l}\text { Ha of degraded forest } \\
\text { reserve planted }\end{array}$ & $\begin{array}{l}60,000 \text { by } \\
2008\end{array}$ & $25,691 \mathrm{ha}$ & $\begin{array}{l}\text { 27,050(HIPC plantation- } \\
10950) \\
\text { (forestry commission-16100) }\end{array}$ & Good progress \\
\hline & $\begin{array}{l}\text { Amount of permanent } \\
\text { employment generated. }\end{array}$ & $\begin{array}{l}100,000 \\
\text { jobs }\end{array}$ & 95,000 jobs & $\begin{array}{c}88,000(\mathrm{HIPC}- \\
18,000 ; \text { Forestry commission- } \\
70,000)\end{array}$ & $\begin{array}{l}\text { Good } \\
+ \text { progress }\end{array}$ \\
\hline
\end{tabular}

Source: MLF

\section{Number of Hectares Planted}

The indicator level for 2004 recorded an increase of 28,400 hectares over the 2003 figure. This represents a cumulative figure of 58,726 hectares by the end of 2004 indicating an excess over the target of 40,000 hectares to be achieved by 2008 . 
Rate of Deforestation

There has been some progress in slowing down deforestation over the period under review.

\section{Hectares of Urban Area and Degraded Forest Planted}

Although the hectares of urban area planted recorded an appreciable level of progress (additional 1,350 hectares in 2004 in addition to the 2003 figure of 1,300), the level of progress is rather slow and is not likely to meet the target of 20,000 hectares by 2008 . There is the need to speed up the process to achieve the target. The target for degraded forest reserve of 60,000ha in 2008 has already been achieved.

\section{Employment Generation}

Permanent employment of 88,000 generated in 2004 indicates good progress towards attaining the target.

\section{Policy Measures}

The strategy for forest resource management include continuing the plantation development programme, extending competitive bidding in allocation of logging rights for existing natural and planted timber, and developing a framework for operationalising an effective log tracking system. It is expected that the plantation cover will be expanded from the 2002 level of 20,000 hectares to 80,000 by end of 2007 .

A Fund has been established for Plantation Development Programme. Under this programme, 58,000ha of plantation is to be developed by June 2005. Quarterly and half yearly reports from four ongoing plantation projects have been produced.

The programme to extend competitive bidding in the allocation of logging rights for existing natural and planted timber is underway. The aim is to increase transparency as well as revenue from Timber Utilization Contract (TUC). Already results of the four TUC Bidding sessions programmed between September 2003 and December 2004 have been verified in reports of the independent auditor and Forestry Commission website. Three of the TUC Bidding sessions have been completed. Also there has been an upward adjustment in stumpage fees from $2.5 \%$ in 2003 to $7 \%$ in 2004 . The total instalments payment expected by June 2005 is $\propto 59.7$ billion. All TUC areas converted to Globally Significant Biologically Areas (GSBAs) as agreed and replacements to the respective companies effected accordingly.

As part of policy to improve governance and reduce leakages from timber revenue there was to be the development of a framework for operationalizing an effective log tracking system. To this end Funds are being sourced from MoFEP to commence implementation.

\section{Policy Objective: Improve Land Administration}

\section{Achievements/Outcomes of Indicators}

Indicators in this area suggest that not much progress was made in 2004. Of the five indicators in this area, only two showed some progress. Table 5.6 illustrates the indicator status for the period under review. 
Table 5.7: Indicator Achievements (2003 - 2004)

\begin{tabular}{|c|c|c|c|c|c|}
\hline $\begin{array}{l}\text { Policy } \\
\text { Objective }\end{array}$ & Indicators & Targets & $\begin{array}{c}\text { Indicator Level } \\
2003 \\
\end{array}$ & $\begin{array}{c}\text { Indicator } \\
\text { Status } 2004\end{array}$ & Progress \\
\hline \multirow{5}{*}{$\begin{array}{l}\text { Improve Land } \\
\text { Administration }\end{array}$} & $\begin{array}{l}\text { No of registered } \\
\text { and } \\
\text { titled urban lands to } \\
\text { individuals }\end{array}$ & $\begin{array}{l}300,000 \\
\text { parcels } \\
\text { by } 2008\end{array}$ & $\begin{array}{c}1,131 \text { certificates } \\
\text { issued }\end{array}$ & $\begin{array}{c}2,555 \text { certificates } \\
\text { issued }\end{array}$ & $\begin{array}{c}\text { Progress } \\
\text { rather } \\
\text { slow }\end{array}$ \\
\hline & $\begin{array}{l}\text { No. of titled and } \\
\text { registered allodial } \\
\text { titles to stools, skins } \\
\text { and tendambas } \\
\text { clans }\end{array}$ & $\begin{array}{l}50 \text { by } \\
2008\end{array}$ & No progress & $\begin{array}{c}\text { Boundary } \\
\text { demarcation on- } \\
\text { going in Ejisu } \\
\text { and Wassa } \\
\text { Amenfi }\end{array}$ & $\begin{array}{c}\text { Some } \\
\text { progress } \\
\text { made }\end{array}$ \\
\hline & $\begin{array}{l}\text { Number of current } \\
\text { land cases } \\
\text { concluded }\end{array}$ & $\begin{array}{c}\text { Reduced by } \\
35,000(2008)\end{array}$ & $\begin{array}{l}\text { Alternative Dispute } \\
\text { Resolution } \\
\text { commences in 2nd } \\
\text { Quarter }\end{array}$ & $\begin{array}{l}\text { Land Courts } \\
\text { being built }\end{array}$ & $\begin{array}{c}\text { Some } \\
\text { progress } \\
\text { made }\end{array}$ \\
\hline & $\begin{array}{c}\text { Number of } \\
\text { customary land } \\
\text { administration units } \\
\text { established }\end{array}$ & 50 by 2008 & $\begin{array}{l}2 \text { established } \\
\text { (Gbawe., } \\
\text { Wassa Amenfi) }\end{array}$ & $\begin{array}{c}3 \text { established } \\
\text { (Kyebi ,Manhyia, } \\
\text { Nadowli) }\end{array}$ & $\begin{array}{c}\text { Progress } \\
\text { rather } \\
\text { slow }\end{array}$ \\
\hline & $\begin{array}{c}\text { Number of regional } \\
\text { land courts } \\
\text { established }\end{array}$ & 10 by (2008) & In proposal stage & In proposal stage & $\begin{array}{c}\text { No } \\
\text { progress }\end{array}$ \\
\hline
\end{tabular}

Source: MLF

The number of titled and registered urban lands to individuals more than doubled from the 2003 level of 1,131 issued certificates to 2,555 in 2004. From Table 5.6, although the indicator - number of registered and titled urban land to individuals - recorded more than $100 \%$ increase over the 2003 level. (2,555 certificates issues in 2004 as against 1,131 in 2003), progress towards target achievement is rather very slow. However one expects that the target of 300,000 parcels of lands by 2008 will be achieved upon the completion of the various interventions under the on-going Land Administration Program. Furthermore, some progress has been made with respect to the number of titled and registered allodial titles to stools, skins and tendambas clans. Boundary demacartion has been on-going in Ejisu and Wassa Amenfi.

The Alternative Dispute Resolution commenced in 2003 has been on-going. Land Title Adjudication Committee to adjudicate on disputes outside the court system has been constituted in Accra and Kumasi. However, information on its impact is unavailable thus one is unable to assess progress towards achieving the target of reducing land cases by 35,000 in 2008 . The decision to establish ten regional land courts by 2008 is still at the proposal stage since 2003.

Furthermore, progress on the establishment of customary land administration units has also been very slow. As at 2004, only three additional units (Kyebi, Manhyia and Nadowli) have been added to the two established in 2003. It is very unlikely to achieve the target of 50 customary land administration units by 2008 unless some radical efforts are put in place

\section{Policy Measures}

As part of Government's objective of improving land administration in the country, plans are underway to establish four land registries in the regions. To this end, it can be said that the process of disaggregating registries has commenced. Office spaces for the 
Regional deed Registries have been provided. Other policy measures undertaken within the period under review include the following:

- An inventory of State Lands was undertaken covering 734 sites as against 1,500 programmed in Accra to inform Government policy on state acquisitions

- Comprehensive proposals for the reform of land legislations and judicial review of conflicting judgements were drafted and subjected to stakeholder reviews

- Comprehensive review of the public land agencies laws was completed and proposal for restructuring and merging six land agencies under the Land Administration Project into one corporate entity has been drafted.

- Revaluation and primary valuation exercise comprising 3,203 properties with a total rateable value of $\$ 258.3$ billion in three district assemblies were carried out to improve financial base of the affected districts

- Digital maps for Accra and Kumasi to facilitate planning of infrastructure were completed. Further 2,322 parcel plans to facilitate land titling were also produced.

- An operational manual to guide staff in the management of public land and appropriate technical support to all other sectors of the economy in the acquisition, use and development of land has been published by the Lands Commission

Others

The Environmental Protection Agency (EPA) is in charge of coordinating, regulating and monitoring environmental impacts of development activities in the country. Some of the activities carried out in 2004 include the following: over 100 applications were processed and about 65 permits issued for non-mining developments; 130 applications and permits were processed for small scale mining, 60 for exploration and 45 for Environment Assessments and Plans. In addition, EPA completed the Strategic Environmental assessment of the GPRS

Under the Environmental Resource Management Programme (ERMP) 5000 farmers, mostly women, were trained in snail farming, bee keeping, and mushroom cultivation in five selected districts.

\section{Policy Recommendations}

Some progress has been made under this policy area. However, efforts should be made to strengthen the institutional capacities of such agencies as Town and Country Planning Department, the Environmental Protection Agency, Ghana Atomic Energy Commission that are directly involved in the implementation of policies aimed at sustained environmental protection.

\subsubsection{Enhanced Infrastructural Development}

The three broad policy objectives under infrastructure development are in the areas of ICT, energy and road transport. There are a total of eleven indicators that form the basis of assessment with ICT, energy and road transport having three, six and two respectively. 


\section{Policy Objective: Increase Telephone Access Outside the Urban Centres and Provide ICT to Schools}

Good progress has been made with all indicators suggesting significant improvements. Table 5.8 indicates the level of progress made in indicator achievement over the period under review.

Table 5.8: Indicator Achievements (2003 - 2004)

\begin{tabular}{|l|l|l|l|l|l|}
\hline $\begin{array}{l}\text { Policy } \\
\text { Objective }\end{array}$ & \multicolumn{1}{|c|}{ Indicators } & Targets & $\begin{array}{l}\text { Indicator } \\
\text { Level 2003 }\end{array}$ & $\begin{array}{l}\text { Indicator } \\
\text { Status 2004 }\end{array}$ & Progress \\
\hline $\begin{array}{l}\text { Increase } \\
\text { Telephone } \\
\begin{array}{l}\text { Access and } \\
\text { provide }\end{array}\end{array}$ & $\begin{array}{l}\text { No. of schools provided } \\
\text { with ICT (computer } \\
\text { terminals + PCs) }\end{array}$ & $\begin{array}{l}514 \text { by } \\
2005\end{array}$ & 257 & 360 & $\begin{array}{l}\text { Good } \\
\text { progress }\end{array}$ \\
\cline { 2 - 6 } & $\begin{array}{l}\text { No. of fixed telephone } \\
\text { lines installed }\end{array}$ & $\begin{array}{l}400,000 \text { by } \\
2005\end{array}$ & 283,000 & $\begin{array}{l}\text { Fixed Line: 315,682 } \\
\text { (Cellular: 1,540,476 } \\
\text { Pay-Phones: 9,933) }\end{array}$ & On track \\
\hline
\end{tabular}

Source: MCT

The number of schools provided with ICT increased from the 2003 level of about 257 to about 360 in 2004. This shows a remarkable progress towards achieving the target of 514 by 2005. It is however very important to re-define this indicator since provision of few personal computers to schools without the necessary connectivity supplements could not amount to the provision of ICT to these schools. There is the need to define what has been provided. In this regard, provision of Internet Connectivity is essential for the improvement of quality education and therefore the need to address the problem of lastmile connections

The number of fixed telephone lines installed also increased significantly from its 2003 level of 283,000. In 2004, 315,682 new fixed lines were installed, recording good progress towards the achievement of the target of 400,000 lines by 2005 .

Furthermore, 1,540,476 cellular phones and 9,933 pay-phones were also provided. Community information centres provided with ICT as part of the HIPC program increased from 12 in 2003 to 52 in 2004

\section{Policy Measures}

The primary goal under this sub-sector is to facilitate the development of a reliable, cost effective ICT infrastructure and services using the latest technologies. To this end some of the activities undertaken in 2004 included the following:

- $50 \%$ of towns with second cycle schools were provided with telephone facilities.

- Teledensity in the country was improved from $4 \%$ to $9.1 \%$ bringing the total number of fixed and mobile lines to 1,835,000 by December 2004.

- 52 Community Information Centres (CICs) were constructed in 2004.

- 50 Postal Agencies were upgraded to Post Offices. These Post Offices will soon be fitted with ICT facilities.

- With respect to the provision of affordable and effective communications for citizens, the following were achieved.

\section{Enabling Environment:}

- New telecommunications Regulations were developed

- A new Telecom Policy was concluded and work commenced for the promulgation of a Telecommunications Act for Ghana 
- A Postal Regulatory Commission was established and draft Postal regulations were discussed

- Mobile licenses for a duration of 15 years to replace authorisation was effected

- A phased process of allowing up to three additional facilities-based international gateway licenses was begun as part of the liberalization of the communications sector

- Clear-cut Interconnection rules were developed including formal service level agreements between parties so as to enhance quality of service.

Provision of Access to Rural Areas

To ensure that lower income sections of society are not deprived of access to telecommunication facilities, the following steps have been taken:

- Establishment of Community Information Centres in 53 districts

- Ghana Investment Fund for Telecommunications development (GIFTEL) was established access financial contributions from government, telecom operators, development partners and others to be distributed to promote universal access

\section{Capacity building}

- Training programs were begun in software management, linux applications, cyber security, computer networking, XDSL technologies, frequency management, gender management etc.

- The Ghana-India Kofi Annan Centre of Excellence in ICT was completed and trained 850 people in various ICT programmes

- ICT awareness training program for traditional rulers has been initiated. Two batches each of 25 chiefs from the Eastern and Greater Accra regions have so far benefited.

\section{Business Promotion}

- Establishment of one Multimedia Centre in Accra as a one stop shop for ICT business

- Pursuance of the Technology Park concept with initial site feasibility undertaken

- Cabinet approval of Policy for Accelerated Development of ICT

In anticipation of increased demand for greater bandwidth to support the development of Internet nationwide the Ministry of Communications initiated an investment drive to build a national communications backbone using the existing VOLTACOM fibre. The Ghana India Kofi Annan Centre for ICT was completed and commenced operations in November 2004.

\section{Policy Objective: Ensure Reliable Supply of High Quality Energy Services}

Indicators that provide information on the improvement in energy sources and usage include ratio of energy demand to supply, proportion of people with access to non-wood fuel energy, proportion of households with electricity, total electricity power generated, lifeline pricing for the electricity sector developed and implemented, and the phasing out of budget subsidies to petroleum sector. Most of the indicators recorded some progress. Electricity lifeline pricing, was developed and implemented in 2003. 
Table 5.9: Indicator Achievements (2003 - 2004)

\begin{tabular}{|c|c|c|c|c|c|}
\hline $\begin{array}{l}\text { Policy } \\
\text { Objective }\end{array}$ & Indicators & Targets & $\begin{array}{l}\text { Indicator Level } \\
2003\end{array}$ & $\begin{array}{l}\text { Indicator } \\
\text { Status } 2004\end{array}$ & Progress \\
\hline \multirow{6}{*}{$\begin{array}{l}\text { Ensure reliable } \\
\text { supply of high } \\
\text { quality energy } \\
\text { services }\end{array}$} & $\begin{array}{l}\text { Ratio of energy } \\
\text { demand to energy } \\
\text { supply }\end{array}$ & $\mathrm{N} / \mathrm{A}$ & 0.73 & 0.73 & $\begin{array}{l}\text { No } \\
\text { change }\end{array}$ \\
\hline & $\begin{array}{l}\text { People with access to } \\
\text { non-wood fuel energy } \\
\text { (over } 68 \% \text { of total } \\
\text { energy consumed in } \\
\text { Ghana is from wood } \\
\text { fuels) }\end{array}$ & $\mathrm{N} / \mathrm{A}$ & $43.4 \%$ & $\begin{array}{l}40 \% \text { (SNEP) } \\
\text { Petroleum: } 29 \% \\
\text { Electricity : } 11 \%\end{array}$ & $\begin{array}{l}\text { On } \\
\text { course }\end{array}$ \\
\hline & $\begin{array}{l}\text { Households with } \\
\text { electricity }\end{array}$ & $\mathrm{N} / \mathrm{A}$ & $50.6 \%$ & $52 \%$ & $\begin{array}{l}\text { Some } \\
\text { progress } \\
\text { made }\end{array}$ \\
\hline & $\begin{array}{l}\text { Total electricity power } \\
\text { generated(megawatts }\end{array}$ & $\mathrm{N} / \mathrm{A}$ & 1,652 & $\mathrm{~N} / \mathrm{A}$ & $\mathrm{N} / \mathrm{A}$ \\
\hline & $\begin{array}{l}\text { Lifeline pricing for } \\
\text { electricity sector } \\
\text { developed and } \\
\text { implemented }\end{array}$ & $\mathrm{N} / \mathrm{A}$ & Done & done & $\begin{array}{l}\text { On } \\
\text { course }\end{array}$ \\
\hline & $\begin{array}{l}\text { Phase out budget } \\
\text { subsidies to } \\
\text { petroleum sector }\end{array}$ & $\mathrm{N} / \mathrm{A}$ & $\begin{array}{l}\text { Process to } \\
\text { remove } \\
\text { subsidies in } \\
\text { place ( Price of } \\
\text { Petroleum } \\
\text { products } \\
\text { increased by } \\
90.4 \% \text { in } 2003 \text { ) }\end{array}$ & $\begin{array}{l}\text { - Participation of the } \\
\text { private sector /Oil } \\
\text { marketing companies in } \\
\text { the importation of } \\
\text { finished products on } \\
\text { March } 312004 \\
\text { - Review of petroleum } \\
\text { pricing formula being } \\
\text { done } \\
\text { Draft Deregulation Bill } \\
\text { being finalized for } \\
\text { Parliamentary approval }\end{array}$ & $\begin{array}{l}\text { On } \\
\text { course }\end{array}$ \\
\hline
\end{tabular}

Source: MOEN

From the table it is observed that the ratio of energy demand to supply did not change for 2004. The proportion of people with access to non-wood fuel energy decreased from the 2003 level of $43.4 \%$ to $40 \%$ in 2004 . The proportion of household with electricity increased from $50.6 \%$ in 2003 to about $52 \%$ in 2004 , suggesting that some progress was made in the year. There is an ongoing progress in relation to the phasing out of petroleum subsidies.

\section{Policy Measures}

The main programme for the energy sector was to continue the energy sector reform. More specifically it was expected that the implementation of the performance-based ECG Management Support Services Agreements would commence during the period.

The process of transforming VRA into three separate companies (the thermal company, the transmission company, and VRA Hydro company and other residual functions) by completing the legal framework, including the passage of revisions to the VRA Act continued. The VRA Amendments Bill was prepared and submitted to Parliament for ratification. Also the revaluation of the assets of VRA which was to form the basis of separation was completed in June 2004 


\section{Policy Objective: Enhanced Access to Markets through Improved Feeder Roads}

Two indicators developed to monitor this policy objective are:

- Length of motorable feeder roads

- Feeder road contract time lag

By 2004 the length of engineered feeder roads had increased to 23,000 km from its 2001 level of $12,700 \mathrm{~km}$. The road condition mix improved from $29 \%$ good, $26 \%$ fair, and $45 \%$ poor in 2001 to $46 \%$ good, $25 \%$ fair, and $29 \%$ poor in 2004 . There have been some difficulties in monitoring the feeder road contract time lag since data have not been available from 2002.

\section{Policy Measures}

In recognition of the impact of improved transport system on poverty reduction and the economy as a whole, the following were undertaken:

- rehabilitate the road infrastructure linking Ghana to her neighbours

- maintain and rehabilitate roads linking the regions

- maintain and rehabilitate as well as construct feeder roads to open up our countryside and accelerate economic activity and thereby ameliorate poverty.

Progress towards the attainment of these objectives is given below:

\section{Rehabilitae the Road Infrastructure Linking Ghana to ber Neighbours}

The following three major highways linking Ghana to her neighbours are under construction. The status of on-going works is provided below.

- The Accra - Yamoransa stretch of highway is about $116 \mathrm{~km}$ in length. Physical completion as at the end of 2004 was $61 \%$.

- The Accra - Aflao road has a total length of $166 \mathrm{~km}$. Significant progress has been made with about $78 \%$ of physical work completed by the end of 2004 .

- The Accra-Kumasi trunk road has a total length of $240 \mathrm{~km}$ with the Ofankor to Nsawam and Kumasi to Fumesua sections to be developed into dual carriageway. The following progress was made by the end of 2004:

\begin{tabular}{|l|c|}
\hline Road Stretch & Level of completion (\%) \\
\hline Ofankor - Nsawam & $71 \%$ \\
\hline Apedwa - Bunso & $100 \%$ \\
\hline Bunso - Anyinam & $100 \%$ \\
\hline Anyinam - Konongo & $94 \%$ \\
\hline Konongo - Kumasi & $8 \%$ \\
\hline
\end{tabular}

Source: MRT

\section{Maintain and Rehabilitate Roads Linking the Region:}

As part of the policy to ensure equity in road development in the country, one major regional trunk road has been selected from each region for improvement to bituminous seal. The total length involved is $1,032 \mathrm{~km}$ at a cost of US\$207.4 million. Progress of work on some of these roads between 2003 and December 2004 are given in Table 5.10 
Table 5.10: Physical Completion of Road Sections under Construction

\begin{tabular}{|l|c|c|}
\hline Project & $\mathbf{2 0 0 3}$ & $\mathbf{2 0 0 4}$ \\
\hline $\begin{array}{l}\text { Wa-Han-Tumu-124km (UWR \& UER) } \\
\text { (Wa - Han Section Under Construction) }\end{array}$ & $15 \%$ & $49 \%$ \\
\hline Hwidiem-Kenyanasi No. 1- Atronie-Sunyani - 63.7km (BAR) & Not Started & \\
\hline Asokwa-Bodwesango-Gyadem-Ofoase-Juaso - 62km (AR) & $45 \%$ & $62 \%$ \\
\hline $\begin{array}{l}\text { Kpando-Worawora-Dambai-Kete Krachie - 249km (VR) } \\
\text { (Kpando - Worawora - Dambai section under construction) }\end{array}$ & $20 \%$ & $55 \%$ \\
\hline Twifo Praso-Dunkwa - 58km (CR) & $10 \%$ & $76 \%$ \\
\hline $\begin{array}{l}\text { Bawdie-Asankragwa-Enchi - 113km (WR) } \\
\text { (Manso - Asankragwa Section under Construction) }\end{array}$ & $46 \%$ & $67 \%$ \\
\hline $\begin{array}{l}\text { Mpraeso-Adawso-Donkorkorm-126km (ER) } \\
\text { (Mpraeso - Adawso Section under construction) }\end{array}$ & $15 \%$ & $35 \%$ \\
\hline Tamale-Yendi - 43km (NR) & $68 \%$ & $94 \%$ \\
\hline $\begin{array}{l}\text { Amasaman-Obeyeyie-Ayikai-Doblo-Odukponkpehe - 19.8km } \\
\text { (GAR) }\end{array}$ & N/A & N/A \\
\hline Sefwi Wiawso - Benkyema Junction - 44.5km (WR) & & Mobilisation \\
\hline
\end{tabular}

Source: Ministry of Road Transport

\section{Maintain and Rehabilitate Feeder Roads}

The main objective of the feeder roads programme is to provide accessibility and mobility in the rural areas, thereby, increasing access to markets, production areas and other social services.

Within the feeder roads programme, Government will embark on tarring a number of feeder roads. Funding required for this tarring programme is US $\$ 35.75$ million to upgrade $715 \mathrm{~km}$ of feeder roads to bituminous surfacing.

In 2001 , the length of engineered feeder roads was $12,700 \mathrm{~km}$. By the end of 2004 , this has increased to $23,000 \mathrm{~km}$. Within the period 2001-2004 the road condition mix improved from $29 \%$ good, $26 \%$ fair, $45 \%$ poor to a condition mix of $46 \%$ good, $25 \%$ fair and $29 \%$ poor.

The new policy in the feeder roads sub-sector is to surface dress (tar) heavily trafficked roads, town roads and roads in second cycle schools. In 2001, the length of tarred roads country-wide, was $860 \mathrm{~km}$. As at the end of September 2004, the length of tarred feeder roads had increased by $320 \mathrm{~km}$. In addition, $250 \mathrm{~km}$ of feeder roads awarded for tarring were at various stages of completion.

In the past year, five thousand $(5,000)$ bridge needs country-wide were inventoried. One thousand two hundred (1200) of these have been prioritised for construction.

In 2004 a total $800 \mathrm{~km}$ of feeder roads underwent spot improvement, while $500 \mathrm{~km}$ of roads were rehabilitated. A total of $250 \mathrm{~km}$ of roads have also been upgraded to bituminous surface. Notable among works carried out by the Department of Feeder Roads are as follows:

(a) Under Spot Improvement projects, the following roads were improved among many others

- Zebilla - Kamenga Junction -UER

- Naha-Loggu - UWR

- Salaga - Kalande - NR
- Atesikrom - Yaakrom (Phase 3) BAR

- Mensonso- Yawusukrom - AR 
- Gyakiti - Ponponano - ER

- Wassa Saaman - Adansi - WR
- Nkonya Ntumuda - Konklobi VR

- Medie - Adjenkotoku - GAR

(b) Regravelling of the following roads among others have been completed.

- Atieku - Nyinase - WR

- Bonso - Dotobaa - Agyeikrom BAR
- Tinkong - Amanfrom - ER

- Sumbrungu - Zokko - UER

(c) Rehabilitation of the following roads has also been completed among others:

- Tokpo - Aveyime - GAR

- Kave - Agorve - Dekpoyaa - VR
- Walewale - Bugya - NR

- Otwereso - Kwaboadi - ER

A total of $293 \mathrm{~km}$ of feeder roads were being upgraded to bituminous seal in 2004, among which include the following:

- Kumasi - Ahodwo - Trede - AR

- Nobekaw - Nyamebekyere - BAR

- Asempanaye - Kushea - CR

- Huhunya - Ehiamankyere - ER

- Amasaman - Odukponkphe (Kasoa) - GAR

- Bole - Bale - NR
- Tilli - Binaba - UER

- Jasikan - Bodada - New Baika VR

- Tarkwa - Bonsa-Bonsawire-WR

- Jirapa - Babile - UWR

\section{Policy Recommendations}

For urban roads the government should consider instituting measures to enable some degree of cost sharing. This will not only speed up developments in this sub-sector, but will also release resources for other areas such as feeder roads programmes and road maintenance. It is recommended that a culture of road maintenance become an integral part of enhancing development in Ghana.

\subsubsection{Strengthening the Private Sector}

GPRS sees the private sector as the key to achieving the overall objective of growth and sustained poverty reduction. To this end, some of the policy measures which were expected to be undertaken in 2004 to help improve the environment for doing business included:

- Strengthen of the Institutional Framework for Implementation of the Strategy

- Complete and begin implementation of the National Trade Policy;

- Establish four (4) Land Registries in the regions;

- Extend GCMS/GCNet facilities to Aflao and Elubo; and

- Complete the automation of Registrar-General's Department

The actual progress in the year is summarised as follows:

\section{Trade and Trade Facilitation}

Cabinet approved the Trade Policy in October 2004 and it was launched in February 2005. Three export trading houses were formed in December 2004.

GCnet is now operational at Aflao. Connection at Elubo was delayed as a result of communication problems. Ghana Telecom the intended service provider has secured the 
necessary permit from the NCA for the use of the equipment required for providing the service. It is anticipated that the Elubo facility finally be operational in 2005.

\section{Improving Business and Investment Environment}

A hardware, network infrastructure and software has been installed at the RegistrarGeneral's Department (RGD) to enable the registration and search for business names to be done electronically. The training of RGD staff in the use of the Registration software which started in 2004 is ongoing. Data in manual registration files were converted to an electronic database for all categories of Business Registration.

A collaboration meeting with MDAs, private sector and civil society was held to discuss the strengthening of the institutional framework for the implementation of the PSDS. As part of the objective of strengthening the institutional framework, the PSDS action plan was translated into implementation work plans and Budget. There was also a validation and publication of performance indicators for implementation with MDAs and the private sector. The terms of reference (TORs) for institutional capacity review (jointly with MPSD) was finalized and submitted to Development Partners in mid-September, 2004.

\section{Manpower Development}

The Ministry of Manpower Development, Youth \& Employment is directly responsible for this policy objective. Some of the activities that were undertaken to enhance employment generation particularly among the youth included the following:

About 12,750 people were trained in 46 trade areas including 'batik tie and dye', food processing, dressmaking, hairdressing, masonry, and carpentry in 2004. This was part of the Phase II of the Skills Training and Employment Programme (STEP). Of the number trained about 3,000 were set up in snail farming, 3,000 in grass cutter rearing and 1,000 in leafy vegetable growing. Additionally over 20 new training centres were established mostly in the rural areas to offer employable skills to the youth.

A total of 20,371 job seekers were placed in various jobs through the Public Employment Centres throughout the country.

\section{Gender and Production}

Government is making efforts to mainstream gender issues into national policies. In the light of this, gender issues have become increasingly visible in various policies. For instance under the President's Special Initiatives some 195,000 hectares of land have been mobilized as equity in 12 Farmer - Owned Companies, for development into plantations. It is noted that women are increasingly involved in providing land for equity and it is therefore anticipated that women will own increasingly, additional shares in the Companies.

The Ministry of Food and Agriculture launched the Gender and Agriculture Development Strategy in 2004. This is to serve as the basis for facilitating the mainstreaming of gender issues in the planning and implementation of agriculture programs.

There is increasing emphasis on attaining gender parity in education with the anticipation that parity will be achieved in primary school gross enrolment by the end of 2005 . 


\section{Policy Recommendations}

It is important that the momentum that is being generated with respect to establishing the private sector as the engine of sustained growth and poverty reduction be maintained. A key ingredient necessary to this momentum is effective monitoring and evaluation. In line with this it is necessary that the various MDAs involved in the implementation of the Private Sector Development Strategy establish as a matter of urgency, benchmarks upon which the move towards making the private sector the engine of growth could be properly assessed.

More attention needs to be given to the gender dimension of Land reform issues. This is to help speed up the correction of discriminatory customary land inheritance systems, which acts against achieving gender parity in production and gainful employment.

\subsection{SUMMARY OF POLICY RECOMMENDATIONS}

\subsubsection{Modernized Agriculture}

Even though most of the indicators in the agricultural sector have recorded some level of progress, there is the need for government to institute measures to arrest the decline in cropped acreage experienced in 2004. This will require a combination of factors among which are turning the apparent increase in irrigation activities into deliverables. In other words the increased number of dugouts should translate into significant increases in the area under irrigation. It is also important that agriculture extension services are made more efficient so that policy measures such as those to increase mechanization and irrigation can effectively complement each other

Ongoing land reform initiatives must be speeded up and carried to completion. Existing laws on land title registration must be enforced. Efforts must be made to streamline and consolidate the functions of the various agencies dealing with land management issues. There is also the need to minimize and eliminate where possible the sources of protracted land disputes, conflicts and litigation.

Major interventions in agriculture would include the provision of improved technological packages and support services to farmers and other operators in the sector. The broad policy intervention will also attract the youth into agriculture and further increase productivity and add value to farm produce. This would lead to an improvement in incomes of farmers as well as ensure a quantum leap in the development of the sector.

\subsubsection{Sustained Environmental Protection}

With the exception of plantation re-transformation, not much progress has been achieved under this policy area. It is therefore important that government redoubles its efforts with regards to this particular area. There is the need for strengthening the institutions (including the Town and Country Planning Department, the Environmental Protection Agency, Ghana Atomic Energy Commission, to mention a few) that are directly involved with the implementation of policies dealing with issues such as environmental regulation, commercial land use, urban land management, zoning, etc. This could be in the form of increasing financial support to enable them undertake their activities effectively as well as forestry support to recruit and retain staff. 


\subsubsection{Enhanced Infrastructural Development}

A lot of progress has been made in this policy area and it is hoped that the momentum will be maintained. The importance of infrastructure development for the other areas under increased production and gainful employment cannot be overemphasized. For urban roads the government could begin to institute measures to enable some degree of cost sharing. This will not only speed up developments in this sub-sector, but will also release resources for other areas such as feeder roads programmes and road maintenance. It is recommended that a culture of road maintenance become an integral part of enhancing development in Ghana. The apparent neglect of existing roads to deteriorate completely before road rehabilitation is undertaken is inefficient and cost ineffective

A comprehensive transportation policy must be implemented that addresses the role of the sector in delivering transport services, serving economic growth, social cohesion and regional integration. Such a policy will include a revival of the dilapidated rail industry, investments in water transportation and other intermodal means of transport, and air transport.

\subsubsection{Strengthening the Private Sector}

It is important that the momentum that is being generated with respect to establishing the private sector as the engine of sustained growth and poverty reduction be maintained. A key ingredient necessary to this momentum is effective monitoring and evaluation. In line with this it is necessary that the various MDAs involved in the implementation of the Private Sector Development Strategy establish as a matter of urgency, benchmarks upon which the move towards making the private sector the engine of growth could be properly assessed.

More attention needs to be given to the gender dimension of Land reform issues. This is to help speed up the correction of discriminatory customary land inheritance systems, which acts against achieving gender parity in production and gainful employment

It is therefore recommended that the respective ministries establish benchmarks and mechanisms to capture and report on progress made. This will imply the compilation and analysis of comprehensive data to assess the extent to which the private sector is responding to the new government initiatives and support for the private sector. 
Table 5.11: Status of Priority Indicators in Production \& Gainful Employment

\begin{tabular}{|c|c|c|c|c|c|c|}
\hline Program Area & Policy Objectives & Indicator & Target & Indicator Level - 2003 & Status in 2004 & $\begin{array}{l}\text { Progress Towards } \\
\text { Targets }\end{array}$ \\
\hline \multicolumn{7}{|c|}{ Modernized Agriculture for Rural Development } \\
\hline \multirow{10}{*}{ Agriculture } & \multirow[t]{3}{*}{ Ensures Food Security } & $\%$ of post harvest losses & $15-20 \%$ & $\begin{array}{l}20-25 \% \text { (cereals) } \\
35-38 \% \text { (perishables) }\end{array}$ & $\begin{array}{l}15-20 \% \\
33-35 \%\end{array}$ & $\begin{array}{l}\text { Target achieved for } \\
\text { cereals } \\
\text { Modest progress made } \\
\text { on perishables }\end{array}$ \\
\hline & & $\begin{array}{l}\text { Tons of major crops } \\
\text { produced }\end{array}$ & & $\begin{array}{l}\text { Maize }=1.29 \mathrm{~m} \mathrm{Mt} \\
\text { Rice }=0.239 \mathrm{~m} \mathrm{Mt} \\
\text { Millet }=0.176 \mathrm{~m} \mathrm{Mt} \\
\text { Sorghum }=0.338 \mathrm{~m} \mathrm{Mt} \\
\text { Cassava }=10.2 \mathrm{~m} \mathrm{Mt} \\
\text { Yam }=3.8 \mathrm{~m} \mathrm{Mt} \\
\text { Plantain }=2.3 \mathrm{~m} \mathrm{Mt}\end{array}$ & $\begin{array}{l}\text { Maize }=1.16 \mathrm{~m} \mathrm{Mt} \\
\text { Rice }=0.242 \mathrm{~m} \mathrm{Mt} \\
\text { Millet }=0.144 \mathrm{Mt} \\
\text { Sorghum }=0.287 \mathrm{~m} \mathrm{Mt} \\
\text { Cassava }=9.7 \mathrm{~m} \mathrm{Mt} \\
\text { Yam }=3.89 \mathrm{~m} \mathrm{Mt} \\
\text { Plantain }=2.38 \mathrm{~m} \mathrm{Mt}\end{array}$ & Mixed result \\
\hline & & $\begin{array}{l}\text { Extension officer farmer } \\
\text { ratio }\end{array}$ & 1:1200 & $1: 1,500$ & $1: 1,400$ & $\begin{array}{l}\text { The ministry is expected } \\
\text { to lower the ratio to } \\
\text { about } 1: 1,000 \text { in five } \\
\text { years time }\end{array}$ \\
\hline & \multirow{4}{*}{ Rehabilitate Fisheries Sector } & $\begin{array}{l}\text { Quantity of fish } \\
\text { produced per unit area of } \\
\text { pond per cycle }\end{array}$ & $\begin{array}{l}3 \text { tonnes } \\
/ \mathrm{ha} / \mathrm{yr}\end{array}$ & 2.5 tonnes $/ \mathrm{ha} / \mathrm{yr}$ & 1.82 tonnes $/ \mathrm{ha} / \mathrm{yr}$ & No progress \\
\hline & & Area under fish farm & $450 \mathrm{ha}$ & $450 \mathrm{ha}$ & $\begin{array}{l}112.3 \text { ha Functional fish ponds } \\
2480.8 \text { ha reservoirs }\end{array}$ & Target exceeded \\
\hline & & $\begin{array}{l}\text { No of hatcheries } \\
\text { constructed }\end{array}$ & 4 & 2 & $\begin{array}{l}\text { (2 Government owned \& } 4 \\
\text { privately owned ) }\end{array}$ & Target exceeded \\
\hline & & $\begin{array}{l}\text { Quantity of fingerlings } \\
\text { produced per annum }\end{array}$ & & 150,000 & $1,760,000$ & Good progress \\
\hline & \multirow[b]{2}{*}{$\begin{array}{l}\text { Provision of Irrigation } \\
\text { Facilities }\end{array}$} & $\begin{array}{l}\text { Percent of arable land } \\
\text { under irrigation }\end{array}$ & $0.12 \%(33,000 \mathrm{ha})$ & currently estimated at $0.08 \%$ & $0.08 \%$ & No progress \\
\hline & & $\begin{array}{l}\text { Number of dugouts } \\
\text { constructed }\end{array}$ & 1,309 & $\begin{array}{l}713 \text { out of } 1309 \text { (bore holes, } \\
\text { dugouts, water storage, } \\
\text { stream diversion, stream and } \\
\text { tube well pumping) were } \\
\text { completed }\end{array}$ & $\begin{array}{l}999 \text { out of the } 1,309 \text { water } \\
\text { facilities were constructed. }\end{array}$ & $\begin{array}{l}286 \text { facilities were } \\
\text { constructed in } 2004 \\
\text { alone }\end{array}$ \\
\hline & & $\begin{array}{l}\text { Farmer access to } \\
\text { mechanized tillage }\end{array}$ & $15 \%$ & $8 \%$ & $12 \%$ & On track \\
\hline
\end{tabular}




\begin{tabular}{|c|c|c|c|c|c|c|}
\hline Program Area & Policy Objectives & Indicator & Target & Indicator Level - 2003 & Status in 2004 & $\begin{array}{l}\text { Progress Towards } \\
\text { Targets }\end{array}$ \\
\hline & \multirow{3}{*}{$\begin{array}{l}\text { Increased Mechanization of } \\
\text { Agriculture }\end{array}$} & Access to harvesters & $5 \%$ & $2 \%$ & $2 \%$ & No progress \\
\hline & & $\begin{array}{l}\text { Access to processing } \\
\text { equipment }\end{array}$ & $30 \%$ & $24 \%$ & $42 \%$ & Target exceeded \\
\hline & & Tractor to farmer ratio & $1: 90,000$ & $1: 150,000$ & $1: 120,000$ & On track \\
\hline \multicolumn{7}{|c|}{ Environmental Protection through Re-forestation } \\
\hline \multirow{11}{*}{$\begin{array}{l}\text { LANDS \& } \\
\text { FORESTRY }\end{array}$} & \multirow{6}{*}{$\begin{array}{l}\text { Increase Environmental } \\
\text { Protection through Re- } \\
\text { afforestation }\end{array}$} & No of hectares planted & 40,000 ha by 2008 & $30,326 \mathrm{ha}$ & $\begin{array}{l}28,400 \text { (this excludes outside reserve } \\
\text { planting) }\end{array}$ & On track \\
\hline & & Rate of deforestation & & 50,000 per year & $\begin{array}{l}\text { Less than } 50,000 \text { (yet to be } \\
\text { determined).Indicator is measured } \\
\text { every } 10 \text { years. }\end{array}$ & On track \\
\hline & & $\begin{array}{l}\text { Number of CRMAS* } \\
\text { established }\end{array}$ & 2 & 1 & nil & No progress \\
\hline & & Ha of urban areas planted & 20,000 ha by 2008 & 1300ha & $1,350 \mathrm{ha}$ in 2004 alone & On track \\
\hline & & $\begin{array}{l}\text { Ha of degraded forest } \\
\text { reserve planted }\end{array}$ & $\begin{array}{l}60,000 \text { by } \\
2008\end{array}$ & $25,691 \mathrm{ha}$ & $\begin{array}{l}\text { 27,050(HIPC plantation-10950) } \\
\text { (forestry commission-16100) }\end{array}$ & Good progress \\
\hline & & $\begin{array}{l}\text { Amount of permanent } \\
\text { employment generated. }\end{array}$ & $\begin{array}{l}100,000 \\
\text { jobs }\end{array}$ & 95,000 jobs & $\begin{array}{l}\text { 88,000(HIPC-18,000;Forestry } \\
\text { commission-70,000) }\end{array}$ & Very good progress \\
\hline & \multirow{5}{*}{$\begin{array}{l}\text { Improve Land } \\
\text { Administration }\end{array}$} & $\begin{array}{l}\text { No of registered and } \\
\text { titled urban lands to } \\
\text { individuals }\end{array}$ & $\begin{array}{l}1,300,000 \\
\text { parcels } \\
\text { by } 2008\end{array}$ & 1,131 certificates issued & 2,555 certificates issued & Progress rather slow \\
\hline & & $\begin{array}{l}\text { No. of titled and } \\
\text { registered allodial titles to } \\
\text { stools, skins and } \\
\text { tendambas clans }\end{array}$ & $\begin{array}{l}50 \text { by } \\
2008\end{array}$ & No progress & $\begin{array}{l}\text { Boundary demarcation in progress in } \\
\text { Ejisu and Wassa Amenfi }\end{array}$ & Slow progress \\
\hline & & $\begin{array}{l}\text { Number of current land } \\
\text { cases concluded }\end{array}$ & $\begin{array}{l}\text { Reduced by } 35,000 \\
(2008)\end{array}$ & $\begin{array}{l}\text { Alternative Dispute Resolution } \\
\text { commences in 2nd Quarter }\end{array}$ & On Going / land Courts being built & Some progres \\
\hline & & $\begin{array}{l}\text { Number of customary } \\
\text { land administration units } \\
\text { established }\end{array}$ & 50 by 2008 & $\begin{array}{l}2 \text { established } \\
\text { (Gbawe., Wassa Amenfi) }\end{array}$ & $\begin{array}{l}\text { established } \\
\text { (Kyebi ,Manhyia, Tabiase) }\end{array}$ & Progress rather slow \\
\hline & & $\begin{array}{l}\text { Number of regional land } \\
\text { courts established }\end{array}$ & 10 by (2008) & In proposal stage & In proposal stage & No progress \\
\hline
\end{tabular}




\begin{tabular}{|c|c|c|c|c|c|c|}
\hline Program Area & Policy Objectives & Indicator & Target & Indicator Level - 2003 & Status in 2004 & $\begin{array}{l}\text { gress Towards } \\
\text { gets }\end{array}$ \\
\hline \multirow[t]{2}{*}{ ICT } & $\begin{array}{l}\text { Increase Telephone Access } \\
\text { Outside the Urban Centres } \\
\text { and provide ICT to Schools }\end{array}$ & $\begin{array}{l}\text { No. of schools provided } \\
\text { with ICT (computer } \\
\text { terminals and PCs }\end{array}$ & 514 by 2005 & 257 & 360 & Good progress \\
\hline & & $\begin{array}{l}\text { No. of fixed telephone lines } \\
\text { installed }\end{array}$ & 400,000 by 2005 & 283,000 & $\begin{array}{l}\text { Fixed Line:315,682 } \\
\text { (Cellular: } 1,540,476 \\
\text { Pay-Phones:9,933) }\end{array}$ & On track \\
\hline \multirow{6}{*}{ Energy } & \multirow{6}{*}{$\begin{array}{l}\text { Ensure reliable supply of } \\
\text { high quality energy services }\end{array}$} & $\begin{array}{l}\text { Ratio of energy demand to } \\
\text { energy supply }\end{array}$ & $\mathrm{N} / \mathrm{A}$ & 0.73 & $* * * 0.73$ & \\
\hline & & $\begin{array}{l}\text { People with access to non- } \\
\text { wood fuel energy(over } 68 \% \\
\text { of total energy consumed in } \\
\text { Ghana is from wood fuels) }\end{array}$ & $\mathrm{N} / \mathrm{A}$ & $43.4 \%$ & $\begin{array}{l}40 \% \text { (SNEP) } \\
\text { Petroleum: } 29 \% \\
\text { Electricity : } 11 \% \\
\end{array}$ & On course \\
\hline & & Households with electricity & $\mathrm{N} / \mathrm{A}$ & $50.6 \%$ & $52 \%$ & \\
\hline & & $\begin{array}{l}\text { Total electricity power } \\
\text { generated(megawatts }\end{array}$ & $\mathrm{N} / \mathrm{A}$ & 1,652 & & \\
\hline & & $\begin{array}{l}\text { Lifeline pricing for electricity } \\
\text { sector developed and } \\
\text { implemented }\end{array}$ & $\mathrm{N} / \mathrm{A}$ & Done & done & On course \\
\hline & & $\begin{array}{l}\text { Phase out budget subsides } \\
\text { to petroleum sector }\end{array}$ & $\mathrm{N} / \mathrm{A}$ & $\begin{array}{l}\text { Process to remove subsidies in } \\
\text { place ( Price of Petroleum } \\
\text { products increased by } 90.4 \% \text { in } \\
2003 \text { ) }\end{array}$ & $\begin{array}{l}\text { Participation of the private sector / Oil } \\
\text { marketing companies in the } \\
\text { importation of finished products on } \\
\text { March } 312004 \\
\text { Review of petroleum pricing formula } \\
\text { being done } \\
\text { Draft Deregulation Bill being finalized } \\
\text { for Parliamentary approval }\end{array}$ & On course \\
\hline \multirow[t]{2}{*}{ Road Sector } & \multirow{2}{*}{$\begin{array}{l}\text { Enhanced access to markets } \\
\text { through improved feeder } \\
\text { roads }\end{array}$} & $\begin{array}{l}\text { Length of motorable feeder } \\
\text { roads }\end{array}$ & & $32,601.8 \mathrm{kms}$ & $23,000 \mathrm{~km}$ & On course \\
\hline & & $\begin{array}{l}\text { Feeder road contract time } \\
\text { lag }\end{array}$ & & $\mathrm{N} / \mathrm{A}$ & $\mathrm{N} / \mathrm{A}$ & On course \\
\hline
\end{tabular}




\begin{tabular}{|c|c|c|c|c|c|c|}
\hline Program Area & Policy Objectives & Indicator & Target & Indicator Level - 2003 & Status in 2004 & $\begin{array}{l}\text { Progress Towards } \\
\text { Targets }\end{array}$ \\
\hline \multirow[t]{3}{*}{$\begin{array}{l}\text { Private Sector } \\
\text { Development \& PSI }\end{array}$} & $\begin{array}{l}\text { Facilitate Private Sector } \\
\text { Access to Long-term Finance }\end{array}$ & $\mathrm{N} / \mathrm{A}$ & $\mathrm{N} / \mathrm{A}$ & & $\begin{array}{l}\text { The following long-term credit facilities } \\
\text { initiated: } \\
\text { - } \quad \text { ADF fund } \\
\text { - } \quad \text { Italian Credit of } € 10 \mathrm{~m} \\
\text { - } \quad \text { Swiss Government } \$ 5 \mathrm{~m} \\
\text { - } \quad \text { HSBC credit of } \$ 40 \mathrm{~m} \\
\text { - } \quad \text { SOFITEL credit of } \$ 17 \mathrm{~m}\end{array}$ & \\
\hline & $\begin{array}{l}\text { Promote Entrepreneurial } \\
\text { Skills }\end{array}$ & $\mathrm{N} / \mathrm{A}$ & $\mathrm{N} / \mathrm{A}$ & & $\begin{array}{l}\text { Key interventions include the following: } \\
\text { Growing the Young Entrepreneur } \\
\text { Captains of Industry program } \\
\text { Captains on the Road program } \\
\text { Students in Free Enterprise }\end{array}$ & \\
\hline & $\begin{array}{l}\text { Facilitate Reduction of } \\
\text { Bottlenecks in Private Sector } \\
\text { Development }\end{array}$ & $\mathrm{N} / \mathrm{A}$ & $\mathrm{N} / \mathrm{A}$ & & $\begin{array}{l}\text { - Institutional \& Legal Reform division } \\
\text { established in the Ministry of Private } \\
\text { Sector Devt. } \\
\text { - Government continued to implement the } \\
\text { recommendations of the Ghana Investors' } \\
\text { Advisory Council in the areas of } \\
0 \quad \text { Financial Sector Reforms } \\
\circ \quad \text { Labour Reforms } \\
\circ \quad \text { Civil Service / Customs reform } \\
\circ \quad \text { Land Reforms } \\
\circ \quad \text { Agric./Agri-business reforms. } \\
\text { The National Medium term Private Sector } \\
\text { Strategy approved and launched. }\end{array}$ & \\
\hline \multirow[t]{2}{*}{ Trade \& Industry } & $\begin{array}{l}\text { Promote SME Industry } \\
\text { Growth and Agro Processing }\end{array}$ & New firms created & $\mathrm{N} / \mathrm{A}$ & $\mathrm{n} / \mathrm{A}$ & & \\
\hline & $\begin{array}{l}\text { Increase External Market } \\
\text { Access }\end{array}$ & N/A & $\mathrm{N} / \mathrm{A}$ & $\mathrm{N} / \mathrm{A}$ & & \\
\hline $\begin{array}{l}\text { Gender \& } \\
\text { Production }\end{array}$ & $\begin{array}{l}\text { Enhance Women Access and } \\
\text { Control of Productive } \\
\text { Resources }\end{array}$ & & & & & \\
\hline $\begin{array}{l}\text { Manpower \& } \\
\text { Development }\end{array}$ & $\begin{array}{l}\text { Enhanced Employment } \\
\text { Generation }\end{array}$ & $\begin{array}{l}\text { Number of functioning } \\
\text { employment centres }\end{array}$ & $\mathrm{N} / \mathrm{A}$ & NA & 62 & \\
\hline
\end{tabular}


Table 5.12: Status of Implementation of PRSC-3 \& MDBS 2005

\begin{tabular}{|c|c|c|c|c|}
\hline Policy Objectives & Measures / Triggers / Activities & Indicators & Targets & Indicator Status as at Oct 2004 \\
\hline \multirow{3}{*}{$\begin{array}{l}\text { Expand supply of } \\
\text { energy services while } \\
\text { protecting the poor. }\end{array}$} & $\begin{array}{l}\text { Maintain implementation of tariff } \\
\text { adjustment mechanism, with life-line } \\
\text { protection for the poor }\end{array}$ & $\begin{array}{l}\text { Transmission of the copies of the gazettes } \\
\text { showing the tariff adjustment according to } \\
\text { the formula as monitored by PURC }\end{array}$ & $\begin{array}{l}\text { Subsidies reduced: } \\
2002 \text { (actual): } ₫ 450 \\
\text { billion }\end{array}$ & \\
\hline & $\begin{array}{l}\text { Continue power sector reform, including } \\
\text { the following } \\
\text { Commence the implementation of the } \\
\text { performance-based ECG Management } \\
\text { Support Services Agreements; and } \\
\text { Continue the process of transforming VRA } \\
\text { into three separate companies (the thermal } \\
\text { company, the transmission company, and } \\
\text { VRA Hydro company and other residual } \\
\text { functions) by } \\
\text { Complete the legal framework, including the } \\
\text { passage of revisions to the VRA Ac } \\
\text { Separate the assets and liabilities, and } \\
\text { Form the new legal entities for these } \\
\text { companies. }\end{array}$ & 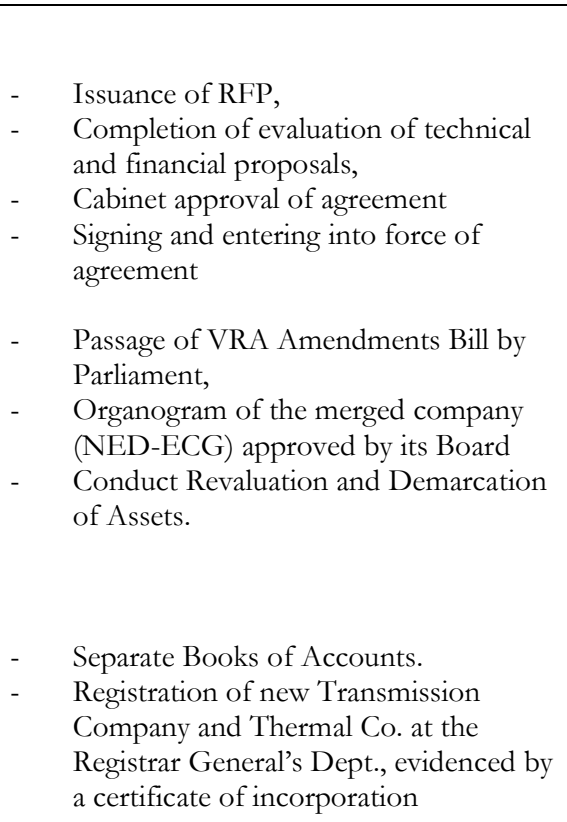 & $\begin{array}{l}\text { System losses } \\
\text { reduced: } \\
2002 \text { (actual): } 26 \% \\
2005 \text { (planned): } 18 \%\end{array}$ & $\begin{array}{l}\text { Final Draft of RfP has been circulated for } \\
\text { comments. RfP to be issued by October 15, } 2004 . \\
\text { Cabinet re-confirmed its decisions on March 25, } \\
2004 . \\
\text { VRA Amendments Bill has been submitted to } \\
\text { parliament for ratification. } \\
\text { VRA Assets Revaluation completed June } 2004 . \\
\text { Consultants have been engaged to carryout } \\
\text { assignment. } \\
\text { Registration Forms have been purchased from } \\
\text { Registrar General's Dept. }\end{array}$ \\
\hline & $\begin{array}{l}\text { Implement } 2004 \text { tranche of the PSDS } \\
\text { action plan, including the } \\
\text { following: } \\
\text { To strengthen the institutional framework for } \\
\text { implementation of the strategy }\end{array}$ & $\begin{array}{l}\text { - Oversight Committee constituted as } \\
\text { evidenced by mandate/TOR for the } \\
\text { committee and minutes from the } \\
\text { meetings of the committee }\end{array}$ & $\begin{array}{l}\text { - Non-traditional } \\
\text { export increase } \\
\text { - Clearance time } \\
\text { at customs } \\
\text { reduced, and }\end{array}$ & $\begin{array}{l}\text { Collaboration meeting with MDAs, private sector } \\
\text { and CSOs held and PSD strategy Action Plan } \\
\text { translated into implementation work plans and } \\
\text { Budget. } \\
\text { Validation and publication of performance }\end{array}$ \\
\hline
\end{tabular}




\begin{tabular}{|c|c|c|c|c|}
\hline Policy Objectives & Measures / Triggers / Activities & Indicators & Targets & Indicator Status as at Oct 2004 \\
\hline $\begin{array}{l}\text { Enhance private sector } \\
\text { competitiveness }\end{array}$ & $\begin{array}{l}\text { To complete and begin implementation of the } \\
\text { National Trade Policy }\end{array}$ & $\begin{array}{l}\text { - Institutionalized review finalized; key } \\
\text { recommendations agreed to by } \\
\text { Oversight Committee, made public and } \\
\text { presented to cabinet. } \\
\text { - Cabinet approval of Trade Policy } \\
\text { Publication and launch of Trade Policy } \\
\text { Commencement of the design of Trade } \\
\text { Sector Support Program } \\
\text { Three (3) Export Trading Houses and } \\
\text { Oversight Committee in operation } \\
\text { Eight (8) External Trade } \\
\text { Representatives to promote trade } \\
\text { diversification and foreign direct } \\
\text { investment functioning } \\
\text { Commencement of Deed Registration } \\
\text { at four (4) Regional offices - Koforidua, } \\
\text { Sunyani, Sekondi and Tamale evidenced } \\
\text { by statistical information including } \\
\text { number of requests for registration and } \\
\text { processing time to register. }\end{array}$ & $\begin{array}{l}\text { number of } \\
\text { consignment } \\
\text { subjected to } \\
\text { physical } \\
\text { examination at } \\
\text { customs } \\
\text { reduced. }\end{array}$ & $\begin{array}{l}\text { indicators with implementation with MDAs and } \\
\text { private sector completed } \\
\\
\text { Validation of Institutional structure for } \\
\text { implementation completed } \\
\text { - Request for proposals to design M \& E } \\
\text { framework issued. } \\
\text { - Final draft of trade policy finished } \\
\text { TORs for institutional capacity review (joint } \\
\text { with MPSD) finalized and submitted to } \\
\text { Development Partners } \\
\text { Cabinet approved the Trade Policy in October } \\
\text { 2004. The Policy will be launched by mid- } \\
\text { February 2005. } \\
\text { International tender for consultants launched in } \\
\text { December 2004. Consultancy contract to be } \\
\text { signed by March } 2005 . \\
\text { Three (3) export trading houses formed in } \\
\text { December } 2004 \text {. Potential candidates to be } \\
\text { short listed in February } 2005 \\
\end{array}$ \\
\hline
\end{tabular}




\begin{tabular}{|c|c|c|c|c|}
\hline Policy Objectives & Measures / Triggers / Activities & Indicators & Targets & Indicator Status as at Oct 2004 \\
\hline & $\begin{array}{l}\text { To extend GCMS/GCNet facilities to } \\
\text { Aflao and Elubo } \\
\text { To complete the automation of Registrar- } \\
\text { General's department }\end{array}$ & $\begin{array}{l}\text { Adverts in the national circulating } \\
\text { newspapers placed by CEPS } \\
\text { announcing dates for the migration to } \\
\text { GCNET when processing customs } \\
\text { entries at Elubo and Aflao. } \\
\text { CEPS letter indicating GCNET is } \\
\text { operational at Aflao and Elubo, } \\
\text { including dates, and copies of GCNET } \\
\text { print-outs from Elubo and Aflao } \\
\text { - Registration and search for business } \\
\text { names at RGD head office is processed } \\
\text { electronically }\end{array}$ & $\begin{array}{l} \\
\text { - Drastic } \\
\text { improvement in } \\
\text { turnaround time } \\
\text { for Business } \\
\text { registrations. } \\
\text { (Average } \\
\text { registration time } \\
\text { reduced to about } \\
3 \text { days.) } \\
\text { Average Time } \\
\text { required to } \\
\text { register a business } \\
\text { reduced to about } \\
3 \text { days from } \\
\text { present baseline of } \\
19 \text { days. } \\
\text { - Search for } \\
\text { Business Name to } \\
\text { be reduced to }\end{array}$ & $\begin{array}{l}\text { Elubo will finally migrate by Q4 } 2004 . \\
\\
\text { O Infrastructure and software installation } \\
\text { completed. } \\
\text { Software implementation at testing stage; To go } \\
\text { live by end Q1 } 2005 . \\
\text { Training of RGD staff in the use of the } \\
\text { Registration software is ongoing. } \\
\text { Conversion of data in manual registration files } \\
\text { to an electronic database completed for all } \\
\text { categories of Business Registration. } \\
\text { New registrations now entered into the } \\
\text { database before signature. }\end{array}$ \\
\hline
\end{tabular}




\begin{tabular}{|c|c|c|c|c|}
\hline Policy Objectives & Measures / Triggers / Activities & Indicators & Targets & Indicator Status as at Oct 2004 \\
\hline & & & $\begin{array}{l}\text { within } 5 \text { minutes } \\
\text { from present } \\
\text { baseline of } 2 \text { days. }\end{array}$ & \\
\hline $\begin{array}{l}\text { Improve rural sector } \\
\text { farm and non-farm } \\
\text { growth }\end{array}$ & $\begin{array}{l}\text { Implement MoFA strategic plan } \\
\text { (focusing on the elements with a } \\
\text { poverty focus and GoG agreed } \\
\text { recommendations of the PSIA and } \\
\text { other analytical studies), including } \\
\text { the following: } \\
\text { (1) }\end{array}$ & $\begin{array}{l}\text { - Distribute the reviewed and costed } \\
\text { strategic plan (2004-2006) to all cost } \\
\text { centers. Commence the implementation } \\
\text { of planned activities at the cost center. } \\
\text { - The report of the multi-disciplinary } \\
\text { committee on identified poverty } \\
\text { focused elements of the } \\
\text { recommendation of the PSIA made } \\
\text { available. } \\
\text { - Demonstrated progress in the revision } \\
\text { of FASDEP to incorporate poverty } \\
\text { reduction approaches as recommended } \\
\text { in the PSIA for agriculture. } \\
\text { - Establishment of RELCs in all the ten } \\
\text { regions and commencement of } \\
\text { operation. Reports/results obtained on } \\
\text { the researchable proposals by scientists. }\end{array}$ & $\begin{array}{l}\text { Real per capita } \\
\text { food production } \\
\text { increases } 2 \\
\text { percent annually }\end{array}$ & $\begin{array}{l}\text { MOFA continues to implement the reviewed } \\
\text { and costed } 2003-2005 \text { strategic plan which has } \\
\text { been reviewed and costed for 2004-2006. From } \\
\text { the 2004-2006 strategic plan, the cost centers } \\
\text { prepared their annual work plans and budget } \\
\text { for the year 2004. Implementations of planned } \\
\text { activities are on-going with the release of the } \\
\text { second and third quarter funds to the cost } \\
\text { centers. } \\
\text { The final report on the PSIA has been } \\
\text { submitted by the consultants. MOFA has } \\
\text { formed a multi-disciplinary committee } \\
\text { including policy advisors which has initiated } \\
\text { activities to identify the poverty -focused } \\
\text { recommendations in the PSIA for } \\
\text { incorporation in the strategic plan of the } \\
\text { reviewed FASDEP (Food and Agriculture } \\
\text { Sector Development Program) and the } \\
\text { reviewed GPRS documents } \\
\text { Detailed schedule of activities has been } \\
\text { developed to be followed in preparing the } \\
\text { reviewed FASDEP. The first draft of the } \\
\text { reviewed FASDEP is expected to be ready by } \\
31 / 5 / 05 \text {. } \\
\text { The Research Liaison Committees are } \\
\text { operational in all the Regions. District Planning } \\
\text { sessions has been held in } 50 \% \text { of the Districts } \\
\text { in the country to gather demand driven } \\
\text { research proposals. Regional review meetings } \\
\text { will examine proposals on prioritized } \\
\text { researchable problems and approve of } \\
\text { proposals for funding by Competitive Agric } \\
\text { Research Grant Scheme. (CARGS). With the } \\
\text { exception of Volta Region, planning sessions }\end{array}$ \\
\hline
\end{tabular}




\begin{tabular}{|c|c|c|c|c|}
\hline Policy Objectives & Measures / Triggers / Activities & Indicators & Targets & Indicator Status as at Oct 2004 \\
\hline & $\begin{array}{l}\text { To engage } 250 \text { additional Extension } \\
\text { Agents; and } 50 \text { agricultural graduates; } \\
\square \text { To reorganize and revitalize policy process } \\
\text { within PPMED }\end{array}$ & $\begin{array}{l}\text { - Letters of engagement available for } \\
\text { verification } \\
\text { - Final report on the New Policy } \\
\text { Making process, the Draft Handbook } \\
\text { on Roles and Responsibilities of } \\
\text { MoFA staff and the Report on the } \\
\text { Change Management process } \\
\text { available for verification. }\end{array}$ & & $\begin{array}{l}\text { have been completed in all the other nine } \\
\text { Regions. } \\
\text { With MoFEPs approval, MoFA has } \\
\text { commenced the process of recruiting the } 250 \\
\text { AEAs and } 50 \text { agriculture graduates annually for } \\
\text { the next five years. The recruitment will help to } \\
\text { improve the Agricultural Extension Agent: } \\
\text { Farmers ratio from the current ratio level of } \\
\text { 1:1500 to 1:1000 for a more efficient extension } \\
\text { service delivery. Interviews have been } \\
\text { conducted and the successful candidates were } \\
\text { recruited, oriented and posted to various } \\
\text { agricultural centers starting November 2nd. } \\
\text { 2004. } \\
\text { Final report on the New Policy Making Process } \\
\text { has been submitted by the consultant to guide } \\
\text { the Ministry in subsequent policy development. } \\
\text { Presentations to staff of MoFA are ongoing. A } \\
\text { Policy Working Group (PWG) has been } \\
\text { formed at the national level to be responsible } \\
\text { for policy formulation. Orientation sessions } \\
\text { for the members of the PWG are on-going. } \\
\text { MoFAs decentralization program has been } \\
\text { reviewed and implementation of } \\
\text { recommendations is on-going. A draft } \\
\text { handbook on roles and responsibilities of } \\
\text { MoFA staff positions has been prepared. } \\
\text { The training of Change Facilitators for } \\
\text { Management of the Change Process in MoFA } \\
\text { has completed two of three modules. }\end{array}$ \\
\hline $\begin{array}{l}\text { Improve management } \\
\text { of natural resources }\end{array}$ & $\begin{array}{l}\text { Implement Government's } \\
\text { strategy for the management of } \\
\text { forestry resources, including the } \\
\text { following: } \\
\square \text { To continue the plantation development } \\
\text { program }\end{array}$ & $\begin{array}{l}58,000 \mathrm{ha} \text { of plantation development } \\
\text { completed by June 2005, being } 71 \% \text { of } \\
\text { programmed target. }\end{array}$ & $\begin{array}{l}\text { - Plantation } \\
\text { cover expanded } \\
\text { from } 20,000 \\
\text { hectares in } \\
2002 \text { to } 80,000\end{array}$ & $\begin{array}{l}\text { Fund established for Plantation } \\
\text { Development. Quarterly and half yearly } \\
\text { reports from } 4 \text { on-going plantation projects. }\end{array}$ \\
\hline
\end{tabular}




\begin{tabular}{|c|c|c|c|c|}
\hline Policy Objectives & Measures / Triggers / Activities & Indicators & Targets & Indicator Status as at Oct 2004 \\
\hline & $\begin{array}{l}\text { To extend competitive bidding in the } \\
\text { allocation of logging rights for existing } \\
\text { natural and planted timber. } \\
\text { To develop a framework for } \\
\text { operationalizing an effective log } \\
\text { tracking system }\end{array}$ & $\begin{array}{l}\text { - All timber utilization contracts of } 2004 \\
\text { bidding program concluded. } \\
\text { Continuation of Timber Utilization } \\
\text { Contract (TUC) bidding program as } \\
\text { per } 2005 \text { schedule (March - Natural } \\
\text { Forest June - Plantation Timber } \\
\text { November - Plantation Timber) } \\
\text { - } \\
\text { Technical Partner selected in June } 2004 \text {. } \\
\text { budget for MLF to include } \\
\text { provision for implementation of } \\
\text { contract with Technical Partner on the } \\
\text { Log Tracking System selected in June } \\
2004 \text {. }\end{array}$ & $\begin{array}{l}\text { hectares by end } \\
2007 \\
\text { - } \quad \text { Transparency } \\
\text { and revenue } \\
\text { from TUC } \\
\text { allocation } \\
\text { increased } \\
\\
\text { - Improved } \\
\text { governance and } \\
\text { reduced leakages } \\
\text { in revenue } \\
\text { earnings from } \\
\text { timber. }\end{array}$ & 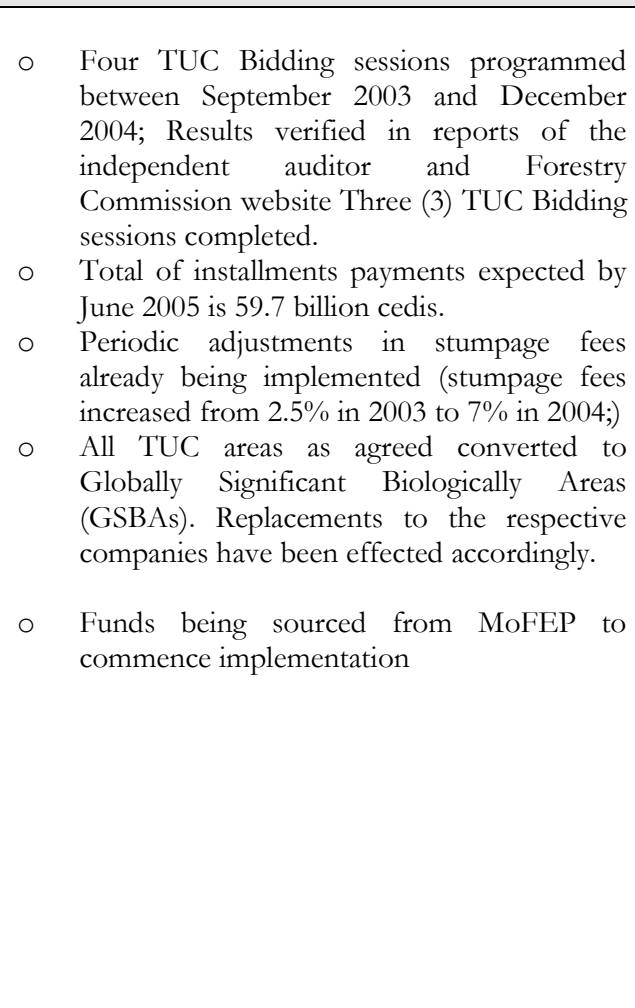 \\
\hline
\end{tabular}




\section{CHAPTER SIX}

\section{HUMAN RESOURCE DEVELOPMENT AND BASIC SERVICES}

\subsection{INTRODUCTION}

The objective of strategies adopted under the HRD thematic area is to improve upon the living conditions of all Ghanaians. To this end the government's medium term priority since the beginning of the implementation of the GPRS in 2002 has focused on the expanding and improving efficiency in the delivery of basic services, while addressing issues of geographical and gender equity in access to these services. The key priority policy measures are in the areas of education and health. In the education sector priority measures include enhancing access to education, reducing gender disparities in education, and improving skills through training. In the health sector priority measures are enhancing access to and delivery of health services, increasing access to safe drinking water in rural areas; and improving access to adequate sanitation.

This section of the report provides a review of the policy actions in the HRD thematic area for 2004. The verification process consists of tracking and evaluating the status of the various policy measures implemented under the government's medium term priorities (MTP) of the GPRS, PRSC-3, and MDBS.

\subsection{REVIEW OF 2003 APR POLICY RECOMMENDATIONS}

Progress made towards the implementation of policy recommendations made in the 2003 APR is presented below in Table 6.1

Table 6.1: Status of 2003 APR Recommended Policy Initiatives

\begin{tabular}{|c|c|}
\hline $\begin{array}{l}\text { SECTOR/POLICY } \\
\text { RECOMMENDATION }\end{array}$ & STATUS \\
\hline \multicolumn{2}{|l|}{ EDUCATION } \\
\hline $\begin{array}{l}\text { Ensure more equity in access to } \\
\text { education }\end{array}$ & $\begin{array}{l}\text { All district approved levies were abolished at the } \\
\text { beginning of the 2004/05 academic year for } 40 \text { deprived } \\
\text { districts and a Capitation Grant Scheme was introduced } \\
\text { to compensate schools for loss of revenue. } \\
\text { Implementation of incentive schemes for girls, including } \\
\text { provision of scholarships and school materials continues } \\
\text { in } 2004 / 05 \text { academic year. } \\
\text { The Education Sector Plan (ESP) began its full } \\
\text { implementation in 2004. One key objective of the ESP is } \\
\text { to address issues of inequities in access to education. }\end{array}$ \\
\hline Enhance quality of education & $\begin{array}{l}\text { Policy to provide incentive packages to teachers in } \\
\text { deprived areas continued in } 2004 \\
\text { District Assemblies Sponsorship Scheme for Teacher } \\
\text { Trainees provided for teachers in remote and deprived } \\
\text { areas. } \\
\text { The policy of achieving a pupil/textbook ratio of } 1: 1 \text { was } \\
\text { vigorously pursued. }\end{array}$ \\
\hline $\begin{array}{l}\text { Undertake impact assessment and } \\
\text { review of teacher retention schemes }\end{array}$ & $\begin{array}{l}\text { A TOR for a study to properly examine issues regarding } \\
\text { the teacher retention and the impact of on-going schemes } \\
\text { is being developed. }\end{array}$ \\
\hline \multicolumn{2}{|l|}{ HEALTH } \\
\hline Develop and implement system for & Criteria for identifying the poor have been defined in the \\
\hline
\end{tabular}




\begin{tabular}{|c|c|}
\hline $\begin{array}{l}\text { better targeting of the poor for } \\
\text { exemptions }\end{array}$ & $\begin{array}{l}\text { NHIS Legislative Instrument and are to be applied by DMIS } \\
\text { to register all exempt categories. }\end{array}$ \\
\hline $\begin{array}{l}\text { Accelerate the implementation of the } \\
\text { NHIS }\end{array}$ & $\begin{array}{l}\text { The National Health Insurance Act (2004), Act 650, has } \\
\text { been enacted. A Legislative instrument, LI 809, has been } \\
\text { passed as operational and administrative guidelines and } \\
\text { also a Ministerial Oversight Committee has been formed. } \\
\text { A National Health Insurance Council and Secretariat are } \\
\text { in place. }\end{array}$ \\
\hline $\begin{array}{l}\text { Strengthen and expand child } \\
\text { malnutrition programmes }\end{array}$ & $\begin{array}{l}\text { Scaling-up of the piloted High Impact Delivery } \\
\text { Programme to reduce under-five mortality, maternal } \\
\text { mortality and malnutrition } \\
\text { Various interventions to reduce malnutrition are at } \\
\text { different stages of implementation. Interventions include } \\
\text { Infant and Young Child Feeding Strategy, Community } \\
\text { Based Nutrition and Food Security Project, } \\
\text { Supplementary Feeding Program in the three Northern } \\
\text { Regions, and promoting the consumption of food rich in } \\
\text { micronutrients (iodine, iron, vitamin A) } \\
\text { The GHS has prepared a concept paper addressing the } \\
\text { problem of malnutrition in the medium term and included } \\
\text { in the MOH/GHS Second Five Year Programme of } \\
\text { Work (5 POW 2002-2006). The objectives include } \\
\text { promoting exclusive breastfeeding, reducing the level of } \\
\text { underweight children, Vitamin A deficiency, iodine } \\
\text { deficiency disorders and universal salt iodization. }\end{array}$ \\
\hline Increase attention to sanitation issues & $\begin{array}{l}\text { No special and specific strategies developed and } \\
\text { implemented in } 2004 \text { to deal with sanitation issues. }\end{array}$ \\
\hline
\end{tabular}

\subsection{EDUCATION SECTOR}

The central theme of the Ghana Poverty Reduction Strategy is that increased access to quality education is essential for socio-economic growth and reducing the incidence of poverty among the Ghanaian population. The key medium term policy objectives of the GPRS have therefore focused on (a) enhancing access to basic education, with special emphasis on gender and geographical equity and (b) improving the quality of education.

This section reports on performance of the education sector, including the status of policy measures implemented in 2004 to improve basic education. Table 6.10 provides a summary of the status of indicators reported on.

\subsubsection{Performance of the Education Sector}

The significant progress registered with access to basic education indicators in 2003 APR continued in 2004. The national primary gross enrolment ratio and those of the deprived regions have all been steadily improving (See Table 6.1). The Northern and Upper West regions in particular have already exceeded their 2005 targets. However, enrolment rates at the national level and in the Upper East region need to be increased by $2.2 \%$ and $1.9 \%$ respectively to be able to achieve their 2005 targets. 
Table 6.1: Trends in Gross Primary School Enrolment Ratio (GPER), 2001/02-2003/04

\begin{tabular}{|l|c|c|c|c|c|}
\hline & $\mathbf{2 0 0 1 / 2 0 0 2}$ & $\mathbf{2 0 0 2 / 2 0 0 3}$ & $\mathbf{2 0 0 3 / 2 0 0 4}$ & $\begin{array}{c}\text { Target } \\
\mathbf{2 0 0 4 / 2 0 0 5}\end{array}$ & $\begin{array}{l}\text { Potential for achieving } \\
\text { 2004/05 target }\end{array}$ \\
\hline PGER & & & & & Likely \\
\hline National & $\mathbf{8 3 . 8 \%}$ & $\mathbf{8 5 . 7 \%}$ & $\mathbf{8 6 . 3 \%}$ & $\mathbf{8 8 . 5 \%}$ & Exceeded \\
\hline Northern & $66.4 \%$ & $70.6 \%$ & $70.5 \%$ & $70.0 \%$ & Unlikely \\
\hline Upper East & $71.2 \%$ & $\mathbf{7 6 . 5 \%}$ & $77.1 \%$ & $79.0 \%$ & Exceeded \\
\hline Upper West & $63.1 \%$ & $70.3 \%$ & $74.1 \%$ & $73.0 \%$ & $\%$ \\
\hline
\end{tabular}

Source: Ministry of Education and Sports, Preliminary Education Sector Performance Report 2004

Note to Table 6.1

1. The GPER is calculated from EMIS census returns. As the return rates for target groups vary by year (94\% for $2002-03$ and $95.5 \%$ in $2003-04$ ), direct year on year comparison is compromised. The GPER figures in the Table have therefore been scaled up to $100 \%$ for all years presented to provide a more accurate and less variable data for assessing education performance.

2. The GPER figures in Tables 5.2 in the 2003 APR are consequently amended.

Efforts toward bridging the gender gap in school enrolment are also yielding positive results but the pace at which the gap is closing has been quite slow. Table 6.2 demonstrates that only moderate gains have so far been made towards girls' enrolments at the national level and in respect of the three deprived northern regions. This observation is confirmed by the data on GPI, which indicates only slightly improved gender parity indices at the national level. It must, however, be noted that national enrolment figures may be masking regional variations as the enrolment of boys actually lags behind that of girls in some regions. The GPI is above the national average in for example the Upper East (0.98) and Upper West (1.02) regions. Improvement in the GPI in these regions may be as a result of GPRS objective of targeting resources in the form of financial and material support to boost girls' enrolment over the years. Overall, the information in Table 5.2 shows that the 2005 targets for gender parity indicators are not likely to be achieved given the present trends in the indicators. Distance to school in some parts of rural areas, poverty, and socio-cultural factors that keep children at home may be some of the underlying reasons for the slow progress in achieving this indicator.

Table 6.2: Trends in Gross Primary Enrolment Ratio for Girls (GPER) and Gender Parity Index (GPI), 2001/02-2003/04

\begin{tabular}{|l|c|c|c|c|c|}
\hline & $2001 / 2002$ & $2002 / 2003$ & $2003 / 2004$ & $\begin{array}{c}\text { Target } \\
2004 / 2005\end{array}$ & $\begin{array}{c}\text { Potential for achieving } \\
2004 / 05 \text { target }\end{array}$ \\
\hline GPER & & & & & Unlikely \\
\hline National & $80.1 \%$ & $82.2 \%$ & $83.1 \%$ & $88.5 \%$ & Unlikely \\
\hline Northern & $56.8 \%$ & $61.8 \%$ & $63.0 \%$ & $70.0 \%$ & Unlikely \\
\hline Upper East & $70.5 \%$ & $76.3 \%$ & $76.4 \%$ & $79.0 \%$ & Exceeded \\
\hline Upper West & $63.1 \%$ & $71.0 \%$ & $74.9 \%$ & $73.0 \%$ & \\
\hline & & & & & \\
\hline GPI & & & & 1.00 & Unlikely \\
\hline National & 0.92 & 0.92 & 0.93 & 1.00 & Unlikely \\
\hline Northern & 0.75 & 0.78 & 0.81 & 1.00 & Unlikely \\
\hline Upper East & 0.98 & 0.99 & 0.98 & 1.00 & Exceeded \\
\hline Upper West & 1.00 & 1.02 & 1.02 & & \\
\hline
\end{tabular}

Source: Ministry of Education and Sports, Preliminary Education Sector Performance Report 2004 Note for Table 6.2

4. The GPER is calculated from EMIS census returns. As the return rates for target groups vary by year (94\% for $2002-03$ and $95.5 \%$ in $2003-04$ ), direct year on year comparison is compromised. The GPER figures in the Table have therefore been scaled up to $100 \%$ for all years presented to provide a more accurate and less variable data for assessing education performance.

5. The GPER figures in Tables 5.3 in the 2003 APR are consequently amended. 
Progress in improving education quality has been more difficult to measure, as academic performance is only measured through the Basic Education Certificate Examinations (BECE) and Senior Secondary Certificate Examinations (SSCE) exams, upon completion of JSS and SSS level respectively. The Ministry of Education and Sports is in the process of introducing a National Minimum Standards as a means of assessing student and sector performance. In the interim, input indicators, such as pupil: teacher ratios (PTRs) and pupil: core textbook ratios have been used to provide proxy measures of quality.

Pupil teacher ratio PTR at the primary level has increased from 31.3:1 in 2002/2003 to 34.0:1 in 2003/2004 academic year, exceeding a targeted ratio of 32.7:1. However, wide variations in the ratio exist at the school and district levels. The percentage of trained teachers at the primary level has improved only marginally in the past three years, with the 40 deprived districts having the lowest levels (Tables 6.3 and 6.4).

With regard to access to core textbooks, the introduction of a new textbook development and distribution policy has led to delays in distribution, resulting in a fall in pupil: core text-book ratio, with the deprived districts being hardest hit (Tables 6.3 and 6.4).

Table 6.3: National Trends in Quality of Education Indicators (2001/02-2003/04)

\begin{tabular}{|l|c|c|c|c|c|}
\hline Indicator & 2001/2002 & 2002/2003 & 2003/2004 & $\begin{array}{c}\text { Target } \\
\text { 2004/2005 }\end{array}$ & $\begin{array}{l}\text { Potential for } \\
\text { achieving } \\
\text { 2005 target }\end{array}$ \\
\hline $\begin{array}{l}\text { \%o of trained } \\
\text { teachers }\end{array}$ & 69.9 & 73.5 & 73.9 & 81.3 & Unlikely \\
\hline $\begin{array}{l}\text { Pupil: Teacher } \\
\text { Ratio (PTR) }\end{array}$ & ---- & $31.3: 1$ & $34.0: 1$ & $33.0: 1$ & Exceeded \\
\hline $\begin{array}{l}\text { Pupil: Core } \\
\text { Textbook Ratio }\end{array}$ & & $1: 1.7$ & $1: 1.4$ & $1: 3.0$ & Unlikely \\
\hline
\end{tabular}

Source: Ministry of Education and Sports, Preliminary Education Sector Performance Report 2004

Table 6.4: Trends in Quality of Education Indicators for 40 Deprived Districts

$(2001 / 02-2003 / 04)$

\begin{tabular}{|l|c|c|c|c|c|}
\hline Indicator & $\mathbf{2 0 0 1 / 2 0 0 3}$ & $\mathbf{2 0 0 2 / 2 0 0 3}$ & $\mathbf{2 0 0 3 / 2 0 0 4}$ & $\mathbf{2 0 0 4 / 2 0 0 5}$ & $\begin{array}{l}\text { Potential for } \\
\text { achieving } \\
\text { 2005 target }\end{array}$ \\
\hline $\begin{array}{l}\text { \% of trained } \\
\text { teachers }\end{array}$ & - & 56.0 & 55.3 & 81.3 & Very unlikely \\
\hline $\begin{array}{l}\text { Pupil: Teacher } \\
\text { Ratio (PTR) }\end{array}$ & --- & $36.6: 1$ & $39.5: 1$ & $33.1: 1$ & $\begin{array}{c}\text { Extremely } \\
\text { unlikely }\end{array}$ \\
\hline $\begin{array}{l}\text { Pupil: Core } \\
\text { Textbook Ratio }\end{array}$ & & $1: 1.3$ & $1: 1.1$ & $1: 3.0$ & $\begin{array}{c}\text { Extremely } \\
\text { unlikely }\end{array}$ \\
\hline
\end{tabular}

Source: Ministry of Education and Sports, Preliminary Education Sector Performance Report 2004

\section{Policy Measures}

The above analysis of the education sector performance indicates that the sector continues to be confronted with a number of policy issues/gaps that remain to be addressed. These include insufficient progress in primary school enrolments; persistent geographical and gender disparities in access to education; and less than satisfactory quality education. In response to these issues a range of policy measures were 
implemented in 2004 to address these problems through the development of the necessary human resources and related social and physical infra-structure.

This section assesses the status of these measures. The assessment is presented in line with the policy objectives of enhance access to education; reduce gender disparities in education; improve vocational skills training: and improve efficiency and equity in education financing.

\section{Policy Objective: Enhance Access to Education}

Specific policy measures implemented in 2004 to enhance access to education included:

- rehabilitate and construction of basic school classrooms

- expand teacher retention schemes

- eliminate all approved district levies and introduce capitation grants in public primary schools in deprived districts

- ensure the timely delivery of core textbooks for primary schools, particularly in most deprived regions

- develop one model senior secondary school with libraries and science laboratories in each of the 110 districts in Ghana

\section{Rehabilitate/construct basic school classrooms}

Two hundred and sixteen (216) out of the four hundred and forty (440) 6-unit classroom blocks under construction were completed in 2004 at the cost of $\phi 103$ billion (Table 6.5). The data indicates clearly that the pace at which classrooms are being provided to boost primary school enrolment is slowing down (the number of classrooms completed decreased from 685 in 2003 to only 216 in 2004). The decrease in the number of completed classrooms was partly due to the ending of DFID school project under which only 3-unit classroom blocks were constructed and the commencement of construction of 6-unit new classroom blocks.

Table 6.5: Trend in number of classrooms rehabilitated/constructed, 2003-2004

\begin{tabular}{|l|l|l|}
\hline Indicator level 2002 & Indicator Level 2003 & $\begin{array}{l}\text { Indicator } \\
\text { Status 2004 }\end{array}$ \\
\hline $\begin{array}{l}585 \text { 3 unit classroom } \\
\text { blocks provided }\end{array}$ & $\begin{array}{l}6853 \text { unit classrooms blocks constructed in } \\
2003\end{array}$ & $\begin{array}{l}\text { Of the 440 6-unit classroom blocks } \\
\text { which were under construction in } \\
2004,216 \text { were completed }\end{array}$ \\
\hline
\end{tabular}

Source: Ministry of Education and Sports, 2004 Performance Report.

The percentage share of the deprived regions in the construction of new classrooms declined from $61 \%$ in 2003 to $22 \%$ in 2004 (Table 6.6)

Table 6.6: Trend in the percent share of the three northern regions in the number of classrooms rehabilitated/constructed, 2002-2004

\begin{tabular}{|l|l|l|l|}
\hline $\begin{array}{l}\text { Indicator level } \\
\mathbf{2 0 0 2}\end{array}$ & Indicator Level 2003 & $\begin{array}{l}\text { Indicator } \\
\text { Status 2004 }\end{array}$ & Progress \\
\hline Not available & $\begin{array}{l}\text { 420 of 685 (61.3\%) of classrooms } \\
\text { constructed were located in the 3 } \\
\text { Northern regions }\end{array}$ & $\begin{array}{l}\text { 96 out of the 440 6-unit }(22 \%) \\
\text { classroom blocks under } \\
\text { construction were located in the } \\
\text { three northern regions. }\end{array}$ & $\begin{array}{l}\text { Percent share of } \\
\text { number of } \\
\text { classrooms } \\
\text { constructed } \\
\text { decreased from }\end{array}$ \\
\hline
\end{tabular}




\begin{tabular}{|l|l|l|l|}
\hline $\begin{array}{l}\text { Indicator level } \\
2002\end{array}$ & Indicator Level 2003 & $\begin{array}{l}\text { Indicator } \\
\text { Status 2004 }\end{array}$ & Progress \\
\hline & & & $\begin{array}{l}61 \% \text { in } 2003 \text { to } \\
22 \% \text { in } 2004\end{array}$ \\
\hline
\end{tabular}

Source: Ministry of Education and Sports, 2004 Performance Report.

Expand Teacher Retention Scheme (PRSC-3/MDBS)

The following activities were undertaken in 2004:

- To improve equity in the distribution of teachers particularly to remote areas, the Ministry of Education and Sports continued to pursue a policy of providing incentive packages to teachers in remote areas in order to improve the. These included the provision of consumer items and accommodation. An amount of $£ 20$ billion was spent on the construction of teachers' residences.

- The District Assemblies Sponsorship Scheme for Teacher Trainees produced 3,812 trained teachers to work in remote areas.

- The National Service Secretariat supplemented the supply of teachers to schools in rural areas with 6,981 teachers through its normal posting of service personnel. In addition 52 teachers were posted to remote rural areas under the National Volunteer Service Programme.

- As a result of these activities the National PTR for primary schools increased. However, the supply of teachers was not enough to improve the PTR in the Northern and Upper East regions (Table 6.7). This situation is attributed to the higher overall enrolment during the year under review, without a corresponding increase in teacher supply.

Table 6.7: PTR in the Northern Regions, 2002/2003 and 2003/2004

\begin{tabular}{|l|c|c|c|c|}
\hline & $\mathbf{2 0 0 2 / 2 0 0 3}$ & $\mathbf{2 0 0 3 / 2 0 0 4}$ & $\begin{array}{c}\text { Target } \\
\mathbf{2 0 0 4 / 2 0 0 5}\end{array}$ & $\begin{array}{c}\text { Potential for achieving } \\
\text { 2004/05 target }\end{array}$ \\
\hline PTR & & & & Exceeded \\
\hline National & $\mathbf{3 1 . 3 : 1}$ & $\mathbf{3 4 . 0 : 1}$ & $\mathbf{3 2 . 7 : 1}$ & Unlikely \\
\hline Northern & $36.3: 1$ & $38.6: 1$ & $35.0: 1$ & Unlikely \\
\hline Upper East & $53.7: 1$ & $58.9: 1$ & $45.0: 1$ & Exceeded \\
\hline Upper West & $47.9: 1$ & $46.2: 1$ & $37.0: 1$ & \\
\hline
\end{tabular}

Source: Ministry of Education and Sports, 2004 Performance Report.

Eliminate all approved district levies and introduce capitation grants in public primary schools in deprived districts.

One of the most important MoEYS programmes implemented this year is concerned with school levies. The present MoEYS policy is that tuition in basic education is free. However, levies are often charged at the district level to cover the costs of school repairs, and cultural and sporting activities. These levies are perceived as a potential barrier to enrolment and retention of the poorest students. Starting from September, 2004 school levies were abolished and capitation grants were introduced in 40 deprived districts. The grant provides all schools in these districts with a decentralised operating budget based on the number of students attending, with higher grant awarded for female students. So far the GES has provided a total of $\phi 13,746,974,999$ for the first and second terms of 2004/2005 academic year to the 40 deprived districts.

Ensure the timely delivery of core textbooks in most deprived districts (PRSC-3/MDBS) 
Pupil: core textbook ratios worsened between 2003 and 2004, particularly in the three deprived northern regions (see Table 6.8) as no new books were procured and distributed. Although an amount of sixteen billion Cedis was transferred in 2004 to the Ministry of Education and Sports for the provision of textbook, no disbursements have yet been made due to a delay in the implementation of a new textbook development and distribution policy. The policy demands strict adherence to the new procurement law, which requires the Ministry to outsource the procurement of textbooks to the private sector.

Table 6.8: Pupil: textbook ratio in the 3 Northern Regions, 2002/2003 - 2003/2004

\begin{tabular}{|l|c|c|c|c|}
\hline & $2002 / 2003$ & $2003 / 2004$ & $\begin{array}{c}\text { Target } \\
2004 / 2005\end{array}$ & $\begin{array}{c}\text { Potential for achieving } \\
2004 / 05 \text { target }\end{array}$ \\
\hline National & $\mathbf{1 : 1 . 7}$ & $\mathbf{1 ; 1 . 4}$ & $\mathbf{1 : 3 . 0}$ & Unlikely \\
\hline Northern & $1: 1.4$ & $1: 1.1$ & $1: 3.0$ & Unlikely \\
\hline Upper East & $1: 1.3$ & $1: 1.0$ & $1: 3.0$ & Unlikely \\
\hline Upper West & $1: 1.5$ & $1: 1.1$ & $1: 3.0$ & Unlikely \\
\hline
\end{tabular}

Source: Ministry of Education and Sports, 2004 Performance Report

\section{Develop/ upgrade one SSS to model status in each district}

The policy to upgrade one Senior Secondary School into model schools reached the second phase in 2004. Work on the first batch of schools is near completion; preliminary studies to determine the scope of works under the second phase of upgrading 25 schools into model schools were completed in 2004 (Table 6.9).

Table 6.9: Trend in number of senior secondary schools upgraded to model status,

2002-2004

\begin{tabular}{|c|c|c|c|}
\hline $\begin{array}{l}\text { Indicator level } \\
2002\end{array}$ & Indicator Level 2003 & $\begin{array}{l}\text { Indicator } \\
\text { Status } 2004\end{array}$ & Progress \\
\hline $\begin{array}{l}31 \text { schools } \\
\text { identified for } \\
\text { upgrading after } \\
\text { assessment of } \\
\text { physical } \\
\text { infrastructure and } \\
\text { academic } \\
\text { requirements }\end{array}$ & $\begin{array}{l}\text { Work on } 31 \text { schools selected } \\
\text { for upgrading progressing } \\
\text { steadily } \\
65.5 \% \text { of work in the } 31 \\
\text { schools completed }\end{array}$ & $\begin{array}{l}\text { Work on the first batch of } 31 \text { schools } \\
\text { is } 65.5 \% \text { complete. Preliminary } \\
\text { studies to determine the second } \\
\text { phase of upgrading } 25 \text { more schools } \\
\text { have been completed }\end{array}$ & On track \\
\hline
\end{tabular}

Source: Ministry of Education and Sports, 2004 Performance Report.

\section{Policy Objective: Reduce Gender Disparities in Education}

The following specific policy measures were implemented in 2004 to reduce gender gap in access to primary education:

- provide incentive/scholarship schemes

- introduce capitation grants for girls in all public primary schools.

\section{Provide incentive/scholarship scheme for girls}

In the 2003/2004 academic year, an amount of $\notin 8.885$ billion from the GET fund was allocated to the Ministry of Education and Sports to provide scholarships for pupils in basic schools, particularly girls. The formula for the disbursement of the fund was as follows:

- sixty percent to be used for girls in primary schools

- thirty-five percent to be used for girls in Junior Secondary schools.

- five percent for special needs such as the handicapped. 
In $2004 \not 4.4$ billion was disbursed to 40 deprived districts out of which $60 \%$ went to girls.

Introduce capitation grants for girls in public primary schools in deprived districts (PRSC-3/MDBS). Capitation grant of $₫ 35,000$ per female pupils has been paid to all public primary schools in 40 deprived districts for the first term of the 2004/2005 academic year. This measure is expected to increase the number of girls enrolled in the deprived districts.

\section{Policy Objectives: Improving Skills Training}

Measures implemented in 2004 to improve technical and vocational skills training included:

- improve technical and vocational education and training

- support and enhancing training for employable skills

Achievements with these measures are presented below:

\section{Improve vocational and technical training}

As part of measures to develop and improve Technical and Vocational Education and Training (TVET) work on a national policy on TVET was completed in 2004. The national TVET policy will guide the development of strategies to enhance technical and vocational skills for an accelerated national development.

Twenty new vocational and technical resource centres were established under GES in the 10 regions located mostly in the rural areas to provide technical and vocational education and training to young men and women.

\section{Support and enbance training for employable skills}

An amount of $\notin 6$ billion micro credit facility was released to the Ministry of Manpower Employment and Youth for disbursement to graduates of the STEP Programme to enable them establish their own small-scale enterprises.

Under Phase 2 of the Skills Training and Employment Programme (STEP), about twelve thousand seven hundred and fifty $(12,750)$ people were trained in various trade areas including food processing, dressmaking, hairdressing, masonry, and carpentry. About 7,000 out of the 12,750 were trained and set up in agricultural vocations such as snail farming, grass-cutter rearing, bee-keeping and mushroom farming

\section{Policy Recommendations}

The analysis indicates the need to reinforce and strengthen efforts to improve primary school enrolment, while closing the geographical and gender gaps in access to education if government's goal of achieving universal primary education by 2015 is to be attained. The government will continue to pursue the policy of enhancing access to quality education in the basic education sub-sector by:

- Accelerating the rehabilitation/construction of primary school classrooms ;

- Promoting and extending pre-school education to stimulate enrolment;

- Rolling out capitation grants to all districts

- Improving per capita resource allocations to most deprived districts to ensure equity in enrolment; 
- Ensuring efficient implementation of the new textbook development and distribution policy for timely delivery of core textbooks;

- Strengthening teacher redeployment measures and ensuring that current teacher incentives are achieving results;

- Expanding and adequately equipping Teacher Training Colleges to increase the supply of qualified teachers;

- Promoting community engagement in the education process to improve school performance;

- Increase resources to vocational and technical institutions for quality skills training. 
Table 6.10: Summary of Status of Indicators in the Education Sector, 2004

\begin{tabular}{|c|c|c|c|c|c|}
\hline Indicator & Target & Indicator Level 2002 & Status in 2003 & Status in 2004 & Progress \\
\hline \multicolumn{6}{|l|}{ CORE INDICATORS/MTP } \\
\hline $\begin{array}{l}\text { Gross Primary enrolment ratio: } \\
\text { National }\end{array}$ & 88.5 & 83.8 & 85.7 & 86.3 & Modest gain \\
\hline $\begin{array}{l}\text { Gross Primary enrolment ratio for Girls: } \\
\text { National }\end{array}$ & 88.5 & 80.1 & 82.2 & 83.1 & $\begin{array}{l}\text { Slow } \\
\text { progress }\end{array}$ \\
\hline $\begin{array}{l}\text { Number of classrooms rehabilitated / constructed } \\
\text { with furniture provided }\end{array}$ & - & - & $\begin{array}{l}6853 \text {-unit classrooms } \\
\text { blocks constructed in } \\
2003\end{array}$ & $\begin{array}{l}\text { Of the } 440 \text { 6-unit classroom } \\
\text { blocks which were under } \\
\text { construction in } 2004,216 \text { were } \\
\text { completed }\end{array}$ & $\begin{array}{l}\text { Number of } \\
\text { completed } \\
\text { classrooms } \\
\text { decreased }\end{array}$ \\
\hline $\begin{array}{l}\text { Share of the three Northern regions in the } \\
\text { rehabilitation / construction of primary classrooms } \\
\text { increased from } 20 \% \text { to } 30 \% \text { in } 2004\end{array}$ & & $20 \%$ & $\begin{array}{l}420 \text { of } 685(61.3 \%) \text { of } 3 \text { - } \\
\text { unit classrooms } \\
\text { constructed were located } \\
\text { in the } 3 \text { Northern } \\
\text { regions }\end{array}$ & $\begin{array}{l}96 \text { out of the } 440 \text { 6-unit }(22 \%) \\
\text { classroom blocks under } \\
\text { construction were located in the } \\
\text { three northern regions }\end{array}$ & $\begin{array}{l}\text { Not } \\
\text { achieved }\end{array}$ \\
\hline $\begin{array}{l}\text { Number of SSS developed upgraded to model sec } \\
\text { schools }\end{array}$ & & $\begin{array}{l}\text { 31schoolsidentified } \\
\text { for upgrading after } \\
\text { assessment of } \\
\text { physical structure } \\
\text { and academic } \\
\text { requirements }\end{array}$ & $\begin{array}{l}\text { Work on the first batch } \\
\text { of } 31 \text { schools began and } \\
65.5 \% \text { of work on } 31 \\
\text { schools completed }\end{array}$ & $\begin{array}{l}\text { Work on the first batch of } 31 \\
\text { schools is almost complete. } \\
\text { Preliminary studies to determine } \\
\text { the second phase of upgrading } 25 \\
\text { more schools have been } \\
\text { completed }\end{array}$ & On track \\
\hline Percentage of trained teachers in primary schools & 81.3 & 69.6 & 73.5 & 73.9 & Stalled \\
\hline \multicolumn{6}{|l|}{ PRSC-3/MDBS } \\
\hline Teacher Retention Scheme expanded & - & - & - & $\begin{array}{l}\text { Policy of providing incentive } \\
\text { packages to teachers in remote } \\
\text { areas continued in 2004.Supply of } \\
\text { teachers still not enough to } \\
\text { improve PTR in Northern and } \\
\text { Upper East regions }\end{array}$ & Achieved \\
\hline
\end{tabular}




\begin{tabular}{|c|c|c|c|c|c|}
\hline Indicator & Target & Indicator Level 2002 & Status in 2003 & Status in 2004 & Progress \\
\hline $\begin{array}{l}\text { Timely delivery of core textbooks in most deprived } \\
\text { districts }\end{array}$ & & & & $\begin{array}{l}\text { No improvement in textbook } \\
\text { ratios in deprived districts for } \\
2004 \text { as no new books were } \\
\text { procured and distributed }\end{array}$ & \\
\hline $\begin{array}{l}\text { All Government controlled fees eliminated and } \\
\text { capitation grants introduced for girls in public } \\
\text { primary schools in deprived districts and in all } \\
\text { public primary schools for the disabled }\end{array}$ & & & & $\begin{array}{l}\text { The GES has drafted guidelines } \\
\text { for the distribution and utilization } \\
\text { of capitation grants } \\
\text { The first instalment of capitation } \\
\text { grant payments of } 25,000 \text { cedis } \\
\text { per male pupil and } 30,000 \text { cedis } \\
\text { per female pupil has been paid to } \\
\text { all primary schools for the first } \\
\text { term of } 2004 / 05 \text { academic year in } \\
40 \text { deprived districts. }\end{array}$ & Achieved \\
\hline $\begin{array}{l}\text { Resources to } 40 \text { deprived districts on the basis of } \\
\text { district plan increased }\end{array}$ & & & & $\begin{array}{l}\text { The percentage of Ghana } \\
\text { Government component of GES } \\
\text { non-salary budget for } 40 \text { deprived } \\
\text { districts increased slightly from } \\
10.1 \% \text { in } 2003 \text { to } 10.2 \% \text { in } 2004 \text {. }\end{array}$ & $\begin{array}{l}\text { No } \\
\text { significant } \\
\text { achievement }\end{array}$ \\
\hline $\begin{array}{l}\text { The execution rate of budgeted non-salary } \\
\text { expenditure not less than } 85 \% \text { in } 2004\end{array}$ & & & & 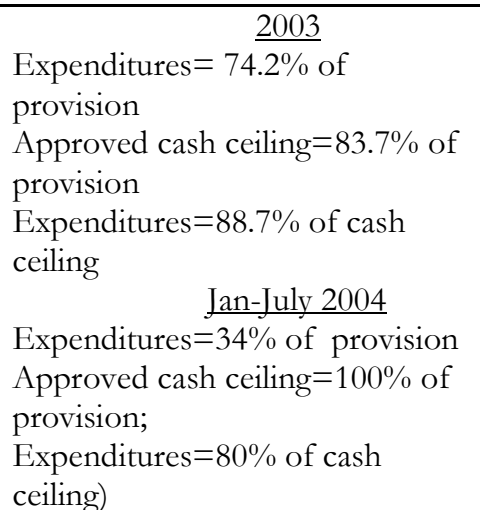 & Achieved \\
\hline
\end{tabular}




\subsection{HEALTH SECTOR}

The goal of the health sector is to improve the health of Ghanaians through achieving the two broad GPRS policy objectives of a) increasing equity in access to basic health services and enhancing efficiency in health care delivery and b) ensuring sustainable financial arrangements that protect the poor

\subsubsection{Performance of the Health Sector}

According to the 2003 APR, the achievements of poverty targeted health interventions with regard to these objectives have so far been mixed. Key child survival outcome indicators like infant mortality, child mortality and child malnutrition have shown worrying changes (Table 6.11a). This is occurring in the context of increasing investments in the health sector (see policy measures below). In response to this state of affairs, the Ministry of Health has undertaken further analysis of the 1998 and 2003 GDHS data to unravel the factors that may be driving the reversal (stagnation) in these child survival indicators. The preliminary results of the analysis seem to suggest the following:

- Neonatal mortality (mostly within the first week of life) accounts for the bulk of observed increase in child mortality.

- Generally, child survival rates are worse in rural areas than urban areas. However, there are indications that rural-urban differentials in child mortality are reducing with child health outcomes in urban areas worsening, due probably to increasing urban slums, poor environmental sanitation and ability to pay for quality health care.

- At the regional level, under-five mortality registered improvements in Gt. Accra, Central, Northern, Upper East and Western regions; worsened in Eastern, Ashanti, and Upper West regions; and stagnated in the Volta and Brong Ahafo regions. With regard to trends in infant mortality, the analysis revealed that that six regions (Gt. Accra, Central, Western, Volta, Upper East, and Northern) improved between 1998 and 2003; the levels in Ashanti, Brong Ahafo and Eastern worsened; while Upper West recorded no change.

- Although higher levels of malnutrition are generally associated with higher levels of under-five mortality, malnutrition alone could not explain the observed underfive mortality rates.

- Safe-motherhood related variables such as breastfeeding, birth intervals, number of births within five years, and mother's education are important risk factors in child survival, particularly at the neonatal period.

- Other service related factors, namely, immunization coverage, antenatal care coverage, use of ITN to control malaria, and prompt management of diarrhoea are all associated with child survival outcomes. We note here that with the exception of supervised deliveries, progress towards improving immunization coverage and antenatal care coverage appears to have stalled between 2003 and 2004 (Table 6.11b; MOH data).

- Concerning environmental factors, source of drinking water appeared to be a significant child survival risk factor in urban areas, but not in rural areas; while sharing of toilet facility increases the risk of under-five deaths in rural areas, but not in urban areas. 
Table 6.11a: Basic Health Sector Indicators, 1988-2003 (\%) based on GDHS

\begin{tabular}{|l|c|c|c|c|c|}
\hline & $\mathbf{1 9 8 8}$ & $\mathbf{1 9 9 3}$ & $\mathbf{1 9 9 8}$ & $\mathbf{2 0 0 3}$ & $\mathbf{2 0 0 4}$ \\
\hline Infant mortality rate & 77 & 66 & 57 & 64 & $\mathrm{~N} / \mathrm{a}$ \\
\hline Under five mortality rate & 155 & 119 & 108 & 111 & $\mathrm{n} / \mathrm{a}$ \\
\hline Child malnutrition (underweight) & 24 & 27 & 25 & 35.8 & $\mathrm{n} / \mathrm{a}$ \\
\hline Maternal mortality rate & 240 & 214 & 214 & $\mathrm{n} . \mathrm{a}$ & $\mathrm{n} / \mathrm{a}$ \\
\hline Total fertility rate & 6.4 & 5.5 & 4.6 & 4.4 & $\mathrm{n} / \mathrm{a}$ \\
\hline
\end{tabular}

Source: GDHS, 1988-2003

Note to Table 6.11a:

The GDHS is conducted 5-yearly to monitor these outcome indicators. Hence, levels of these indicators are not available for 2004.

Table 6.11 b: Basic Health Sector Indicators (\%), 2001-2004

\begin{tabular}{|ll|c|c|c|c|}
\hline & & $\mathbf{2 0 0 1}$ & $\mathbf{2 0 0 2}$ & $\mathbf{2 0 0 3}$ & $\mathbf{2 0 0 4}$ \\
\hline Immunization coverage (DPT3) & MOH & 76.3 & 77.9 & 76.0 & 75.0 \\
\hline & GDHS & $47.0(1988)$ & $62.0(1998)$ & 69.4 & $\mathrm{n} / \mathrm{a}$ \\
\hline Supervised deliveries & MOH & 49.2 & 44.3 & 51.9 & 53.4 \\
\hline & GDHS & & $44.3(1998)$ & 47.1 & $\mathrm{n} / \mathrm{a}$ \\
\hline Antenatal care coverage & MOH & 93.5 & 93.7 & 91.2 & 89.2 \\
\hline & GDHS & $82.0(1988)$ & $89.0(1998)$ & 92.0 & $\mathrm{n} / \mathrm{a}$ \\
\hline
\end{tabular}

Source: Yearly Health Sector Programme of Work Reviews/GDHS. 1988-2003

The key issues emerging from the above analysis are summarised as follows:

- the persistence of regional differentials in child survival outcomes suggests that the GPRS policy objective of enhancing equity in access to health services remains relevant. However, the current strategy of targeting resources to deprived regions may be compromising the achievement of national health targets.

- the reversal/stagnation of child survival outcomes despite increase in health investments suggest service delivery constraints (including human resource management), particularly in the delivery of maternal and child health programmes. Another key factor is the malaria burden. Malaria remains the leading cause of morbidity and mortality in the country, accounting for about $40 \%$ of all out-patients attendance and $25 \%$ of under-five mortality. Prevention and improvement in the management of malaria is therefore critical in the reducing childhood mortality.

- the emerging poor performance of child survival indicators among the urban poor may be indicative of the existence of non-physical barriers to health services, including financial barrier.

The next section presents policy measures implemented in 2004 to address some of these issues.

\section{Policy Measures}

Policy measures implemented in 2004 to strengthen and improve health sector performance focussed on bridging equity gaps in access to health care; improving efficiency in health care delivery; providing financial arrangements that make health care affordable to all Ghanaians. This section evaluates the status of these measures. 


\section{Policy Objective: Bridge Equity Gaps in Access to Quality Health Care}

The specific programmes and projects implemented to achieve this health policy objective were:

Infrastructural development to support pro-poor service provision:

- increase the coverage of Community Health Planning and Services

- provide one model hospital in each targeted deprived district and model health centre in each targeted deprived sub-district

Strengthening and expanding high impact, rapid delivery strategies in service provision:

- implement high impact and rapid delivery programmes to reduce under-five mortality and maternal mortality

- assess health worker attraction and retention programmes

- continue the process of decentralizing management of human resources, including the identification of options for decentralizing P.E.

Increase the coverage of Community Health Planning and Services (CHPS)

The CHPS is a key GPRS initiative aimed at bridging the equity gaps in access to quality health care and removing non-financial constraints to health care delivery through a 'close to client' approach to service delivery. The CHPS is designed to deliver a specific basic package of services or essential interventions at the sub-district level (with population of 500-5,000 people). Eighteen (18) CHPS compounds were completed in 4 deprived regions at the cost of 10 billion Cedis from HIPC funds in 2004. This represents improvement on the 15 such compounds constructed in 2003 in two deprived regions.

Provide one model hospital in each deprived district and at least one model health centre in each identified deprived sub-district

One key medium term strategy to enhance access to health care and improve health outcomes under the GPRS is to provide one model health facility in each district. In 2004, fifteen health centres and three district hospitals were completed for use. Other projects that were either commenced or undertaken to increase access included:

- preliminary work on 12 sites for upgrading, rehabilitation, and construction of health facilities completed

- the commencement of the rehabilitation of Bolgatanga and Tamale hospitals

- the commencement of upgrading and re-equipping of Mamprobi and Kaneshie Polyclinics

- the upgrading of Juabeso, New Edubiase, and Nkwanta Health Centres to District hospitals.

- rehabilitation of wards and administrative buildings at Korle-Bu and Okomfo Anokye Teaching Hospitals initiated.

Implement high impact and rapid delivery programmes to reduce under-five mortality and maternal mortality (HIRDP)

The Ministry of Health in collaboration with UNICEF has been implementing this programme in Northern an Upper East regions on pilot basis. The recent improvement in U5MR in the Upper East region (UER) attests to the positive impact of this intervention. The region has moved from among the three bottom regions (include Northern and Upper West) with the worst U5MR in 1998 to be among the top three regions (regions with lowest rates) by 2003. Consequently an assessment was carried out on the programme in UER in 2004 to determine the cost effectiveness of the strategy. 
Lessons learnt from the study are being used to work out modalities for scaling up and rolling the programme to other regions.

Assess health profession attraction and retention scheme (PRSC-3/MDBS)

Key service delivery constraints facing the health sector include inadequate number of health care professionals due to migration and an unequal distribution of the stock of trained health workers. A reviewed report on health professional attraction and retention has been prepared and discussed. The indicator has therefore been achieved.

Continue the Process of Decentralized management of buman resources, including the identification of options for decentralizing P.E (PRSC-3/MDBS)

This measure was implemented to overcome the over-centralized nature of human resource management in the health sector and thereby improve efficiency in service delivery. The trigger was partially achieved as options paper on decentralizing P.E has been prepared and awaiting discussion with the Ministry of Finance and Economic Planning (MoFEP) before submission to Cabinet.

Increase utilization of health services in deprived regions (MDBS)

This indicator was achieved. According to GES records, coverage of supervised delivery in all the four deprived regions improved in 2004.

\section{Policy Objective: Ensure Sustainable Financing Arrangements that Protect the Poor}

Measures implemented in 2004 to achieve this policy objective included:

- Accelerating the implementation of the National Health Insurance Scheme;

- Increasing funding and coverage of exemptions to include maternity delivery in two additional regions;

- Developing and implementing systems for identifying the poor for exemptions from fees/health insurance premia subsidy

- Revising the health expenditure allocation formula to include goods, services and investments in favour of the most disadvantaged districts;

- Increasing health expenditure as total of government expenditure

Accelerate the implementation of the National Health Insurance Scheme, including laying Legislative Instrument for the National Health Insurance before Parliament (PRSC-3/MDBS)

The implementation of the NHIS was accelerated in 2004 following the passage of the National Health Insurance ACT 650 in 2003. The achievements in the implementation of the NHIS include:

- inauguration of the National Health Insurance Programme

- establishment of National Health Insurance Council

- preparation and subsequent approval of Legislative Instrument 1809.

- establishment of a permanent NHIS Secretariat.

- appointment of staff for District Mutual Health Insurance Schemes (DMHIS)

- operationalisation of NHIS in 15 districts

- registration and collection of contributions in 78 districts

- coding of streets and houses in 16 districts

- development of accreditation tools for Health Centres, District Hospitals, Regional and Tertiary Hospitals 


\section{Funding of NHIS}

As at November 2004, an amount of about $₫ 484,000,000,000$ has been raised by the National Health Insurance Fund from the various accredited sources (see Table 6.12)

Table 6.12: NHIS Fund by Source, November 2004

\begin{tabular}{|l|l|}
\hline Source of Fund & Amount in cedis \\
\hline VAT & $126,182,633,965.43$ \\
\hline SSNIT & $171,912,802,532.09$ \\
\hline CEPS & $186,613,103,347.43$ \\
\hline TOTAL & $\mathbf{4 8 4 , 7 0 8 , 5 3 9 , 8 4 4 . 9 5}$ \\
\hline
\end{tabular}

Increase funding and coverage of exemptions to include maternity delivery in two additional regions

Money allocated to exemption in the budget increased from $\notin 24$ billion in 2003 to $\varnothing 26$ billion in 2004 and disbursed to the regions based on target population. Maternal delivery exemptions continued to be implemented in the four deprived regions and were extended to Western and Eastern in 2004. Evidence from the six shows increase in uptake of ANC and supervised delivery indicating that the policy measure has been effective

Develop and implement systems for identifying the poor for exemptions from fees/ health insurance premia subsidy (PRSC-3/MDBS)

An amount of $\propto 13$ billion was allocated in the 2005 budget for exemptions. The implementation of the policy is, however, changing under the national health insurance scheme. It is expected that the budget will continue to support free public health services while the NHIS exempts and registers the poor. The criteria for identifying the poor has already been defined in the NHIS Legislative Instrument and DMIS have been requested to register all exempt categories.

Revise the bealth expenditure allocation formula to include goods, services and investments in favour of the most disadvantaged districts (PRSC-3/MDBS)

This trigger was partially achieved. The GHS has revised the resource allocation criteria and applied to items 2 and 3. However, the modalities for decentralising the Capital budget (Item 4) is currently being worked out and is expected to be operational for the 2006 Planning and Budgeting Process.

Analysis of allocation to deprived areas compared to non deprived areas is also currently ongoing and expected to be ready by March 2005. Findings will be used to refine the allocations.

\section{Increase bealth expenditure as total of government expenditure}

In line with the Government's objective of improving the level and distribution of health resources, the proportion of non-wage recurrent expenditure on health has been increasing. The proportion increased from $10.5 \%$ in 2002 to $11.8 \%$ in 2003 and then $12 \%$ in 2004. This positive achievement in health expenditure is, however, occurring in the context of reversal/stagnation of key health outcome indicators such as child mortality and child malnutrition.

\section{Policy Recommendations}

The results of this monitoring exercise shows that the health sector continues to be plagued by issues relating to geographical gaps in health outcomes, health services 
delivery (e.g. adequacy of child survival programmes), and targeting of resources. The current targeting of resources to deprived regions, for example, appears to be yielding positive results as evidenced by child health indicators in these regions. At the same time health outcomes in regions not currently classified as deprived such as Ashanti and Eastern are worsening. Another important issue that emerged from the analysis is the deteriorating child health among the urban poor, which may be due in part to financial constraints and poor access to adequate sanitation and safe drinking water. To these can be added management and human resource constraints. In view of these problems government will direct its efforts into:

- accelerating the provision/upgrading of district model hospitals and sub-district health centres; and expanding the coverage of CHPS compounds.

- expanding the training of health care professionals

- ensuring efficient implementation of health professional attraction and retention scheme

- accelerating the implementation of the NHIS and ensure that measures for better targeting of the poor for exemptions within the NHIS are fully implemented.

- strengthening Safe Motherhood programmes, including the promotion of early breastfeeding and family planning.

- expanding the Integrated Management of Childhood Illness (IMCI) programme to all districts to reduce child mortality. Currently 50 out of the 138 districts in the country are benefiting from this initiative.

- ensuring the prevention and improvement in the management of malaria

- emphasizing the synergy between health service provision and the delivery of safe water and sanitation through health education and strengthening collaboration between $\mathrm{MOH} / \mathrm{GES}$ and other relevant implementing agencies. 
Table 6.13: Summary of Status of Core Health Indicators in 2004

\begin{tabular}{|c|c|c|c|c|c|}
\hline Indicator & $\begin{array}{l}\text { Target } \\
2005\end{array}$ & 2002 & $\begin{array}{l}\text { Indicator } \\
\text { Status } 2003\end{array}$ & Status 2004 & Progress \\
\hline \multicolumn{6}{|l|}{ CORE INDICATORS (MTP) } \\
\hline $\begin{array}{l}\text { Infant mortality (per } 1000 \text { live } \\
\text { births) }\end{array}$ & & 57 (1998) & 64 & $\mathrm{n} / \mathrm{a}$ & Reversing \\
\hline $\begin{array}{l}\text { Child malnutrition ( } \% \text { of children } \\
\text { underweight) }\end{array}$ & & $25 \%(1998)$ & $35.8 \%$ & $\mathrm{n} / \mathrm{a}$ & Worsening \\
\hline $\begin{array}{l}\text { Immunization Coverage } \\
\text { GDHS }\end{array}$ & $90.0 \%$ & $62.0 \%(1998)$ & $69.4 \%$ & $\mathrm{n} / \mathrm{a}$ & \\
\hline MOH & & 77.9 & 76.0 & 75.0 & Not on track \\
\hline $\begin{array}{l}\text { Proportion of supervised } \\
\text { deliveries }\end{array}$ & $55.0 \%$ & $44.3 \%(1998)$ & $47.1 \%$ & $\mathrm{n} / \mathrm{a}$ & \\
\hline MOH & & 44.3 & 51.9 & 53.4 & On track \\
\hline $\begin{array}{l}\text { Health expenditure increased } \\
\text { from } 5.7 \text { in } 2000 \text { to } 7 \% \text { of total } \\
\text { government expenditure in } 2003\end{array}$ & $7 \%$ & $10.5 \%$ & $11.8 \%$ & $12.0 \%$ & On Track \\
\hline $\begin{array}{l}\text { At least } 10 \% \text { increase in amount } \\
\text { budgeted for exemption }\end{array}$ & $\begin{array}{ll}--- \\
-1\end{array}$ & $21 \%$ & $24 \%$ & $26 \%$ & On track \\
\hline $\begin{array}{l}\text { Reported number of guinea worm } \\
\text { cases }\end{array}$ & 0 & 5,545 & 8,290 & 7275 & $\begin{array}{l}\text { Slight deduction } \\
\text { in the number of } \\
\text { cases }\end{array}$ \\
\hline \multicolumn{6}{|l|}{ PRSC-3/MDBS } \\
\hline $\begin{array}{l}\text { Assess health profession } \\
\text { attraction and retention scheme }\end{array}$ & & & & $\begin{array}{l}\text { A reviewed report on } \\
\text { health professional } \\
\text { attraction and } \\
\text { retention has been } \\
\text { prepared and } \\
\text { discussion of the } \\
\text { report is currently } \\
\text { ongoing }\end{array}$ & Achieved \\
\hline $\begin{array}{l}\text { The Process of Decentralizing } \\
\text { management of human resources, } \\
\text { including the identification of } \\
\text { options for decentralizing P.E } \\
\text { continued. }\end{array}$ & & & & $\begin{array}{l}\text { Options paper on } \\
\text { decentralizing P.E has } \\
\text { been prepared and } \\
\text { awaiting discussion } \\
\text { with the Ministry of } \\
\text { Finance and } \\
\text { Economic Planning } \\
\text { before submission to } \\
\text { Cabinet. }\end{array}$ & Partially achieved \\
\hline $\begin{array}{l}\text { Utilization of health services in } \\
\text { deprived regions increased } \\
\text { (coverage of supervised deliveries } \\
\text { increased) }\end{array}$ & & & & $\begin{array}{l}\text { Coverage of } \\
\text { supervised delivery in } \\
\text { all the four deprived } \\
\text { regions improved in } \\
2004 .\end{array}$ & Achieved \\
\hline $\begin{array}{l}\text { Systems for identifying the poor } \\
\text { for exemptions from fees/health } \\
\text { insurance premia subsidy } \\
\text { developed and implemented }\end{array}$ & & & & $\begin{array}{l}\text { An amount of } 13 \\
\text { billion Cedis was } \\
\text { allocated in the } 2005 \\
\text { budget for } \\
\text { exemptions. The } \\
\text { criteria for identifying } \\
\text { the poor has already } \\
\text { been defined in the } \\
\text { NHIS Legislative } \\
\text { Instrument }\end{array}$ & Achieved \\
\hline $\begin{array}{l}\text { Health expenditure allocation } \\
\text { formula revised to include goods, } \\
\text { services and investments in } \\
\text { favour of the most disadvantaged } \\
\text { districts }\end{array}$ & & & & $\begin{array}{l}\text { The GHS has revised } \\
\text { the resource allocation } \\
\text { criteria and applied to } \\
\text { items } 2 \text { and } 3 \text {. }\end{array}$ & Achieved \\
\hline
\end{tabular}




\subsection{WATER AND SANITATION SECTOR}

The goal of the water and sanitation sector is to increase the proportion of the population with access to safe water and sanitation, with special emphasis on guinea worm endemic areas.

\subsubsection{Performance of the Water and Sanitation Sector}

Access to safe drinking water remains a perennial problem in many rural communities. Although Table 5.20 shows that good progress has been made in enhancing access to safe water for the rural population, a significant proportion $(48.3 \%)$ of them continue to rely on unsafe sources of water such as ponds, streams, and unprotected wells. Access to adequate sanitation in the rural areas is also quite poor, especially in the deprived northern regions (see 2003 APR). This section provides the implementation status of measures adopted in 2004 to improve access to safe water and adequate sanitation in rural areas.

Table 6.14: Summary of Indicators on Access to Safe Water in Rural Areas

\begin{tabular}{|l|l|l|l|l|l|}
\hline Indicator & $\begin{array}{l}\text { Target } \\
\mathbf{2 0 0 5}\end{array}$ & $\mathbf{1 9 9 8}$ & $\begin{array}{l}\text { Indicator } \\
\text { Status } \\
\mathbf{2 0 0 3}\end{array}$ & $\begin{array}{l}\text { Indicator } \\
\text { status } \\
\mathbf{2 0 0 4}\end{array}$ & Progress \\
\hline $\begin{array}{l}\text { Percentage of rural population } \\
\text { with access to safe water } \\
\text { sources }\end{array}$ & $\mathbf{4 6 \%}$ & $\begin{array}{l}40 \% \\
(2000)\end{array}$ & 46.4 & 51.7 & $\begin{array}{l}\text { Good progress; } \\
\text { about 5\% } \\
\text { increase in } \\
\text { coverage }\end{array}$ \\
\hline $\begin{array}{l}\text { Percentage of rural population } \\
\text { with access to adequate } \\
\text { sanitation (2003 CWIQ) }\end{array}$ & --- & $45.8 \%$ & $55.0 \%$ & Not available & \\
\hline $\begin{array}{l}\text { Incidence of guinea worm } \\
\text { reported reduced }\end{array}$ & 0 & $\begin{array}{l}5,545 \\
2002\end{array}$ & 8,290 & 7,275 & $\begin{array}{l}\text { Slight } \\
\text { reduction in } \\
\text { the number of } \\
\text { cases }\end{array}$ \\
\hline
\end{tabular}

Source: 2003 GPRS Annual Progress Report/ Ministry of Health 2004 Performance Report/ 2004 CWSA

Notes: CWSA defines access to safe water to include the following elements:

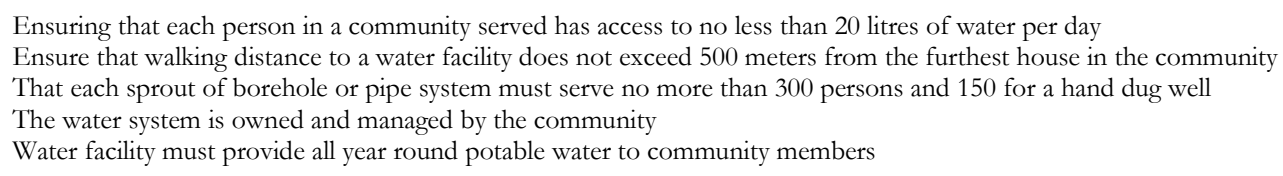

\subsubsection{Incidence of guinea worm}

Efforts to eradicate guinea worm infection have produced mixed results over the years. Table 6.15 provides information on trends in reported number of guinea worm cases. There are indications that the reported number of cases, which has been increasing since 2001, is beginning to decline as the number of cases decreased between 2003 and 2004. The most affected endemic areas in the country remains the Volta, Northern and Brong Ahafo regions.

Interventions for preventing the transmission of guinea worm were strengthened in 2004. Currently about 13,300 communities are under surveillance, of which 1,289 reported cases of guinea worm infection. The proportion of guinea worm endemic villages with access to potable water is $47 \%$ at the time of this report. Further, the overall case containment at mid-2004 was 59\% as against a target of $70 \%$ for the year. 
Table 6.15: Trends in the reported cases of Guinea Worm

\begin{tabular}{|l|c|c|}
\hline Year & Reported cases & $\begin{array}{c}\text { Annual change in number of } \\
\text { reported cases }\end{array}$ \\
\hline 2001 & 4,738 & ---- \\
\hline 2002 & 5,545 & 807 \\
\hline 2003 & 8,290 & 2745 \\
\hline 2004 & 7275 & -101.5 \\
\hline
\end{tabular}

Source: $\mathrm{MOH}, 2004$ Performance reports.

Analysis of incidence of guinea worm disease by region show that the disease is more endemic in the Northern, Volta, Brong-Ahafo and Upper West regions, accounting for $97 \%$ of all reported cases of the disease (Table 6.16). At the district level, the most endemic areas are Tolon-Kumbungu, Savelugu-Nanton, WA and Nkwanta.

Table 6.16: Incidence of guinea worm cases by region, 2003 and 2004

\begin{tabular}{|l|r|r|}
\hline Region & Year 2003 & Year 2004 \\
\hline Northern & 5999 & 4979 \\
\hline Volta & 1511 & 1604 \\
\hline Brong Ahafo & 492 & 336 \\
\hline Upper West & 152 & 222 \\
\hline Ashanti & 45 & 85 \\
\hline Eastern & 37 & 27 \\
\hline Upper East & 23 & 15 \\
\hline Western & 28 & 4 \\
\hline Greater Accra & 3 & 3 \\
\hline Central & 0 & $\mathbf{7 2 7 5}$ \\
\hline
\end{tabular}

Source: MOH Performance Report. 2004

\section{Policy Measures}

Activities undertaken in 2004 to increase the proportion of rural population with access to safe water and sanitation included:

- The construction of new water points and the rehabilitation of malfunctioning water systems

- Implementation of Cabinet-approved comprehensive sector policy

- Undertaking hydrological data base for better targeting of investments

- Supporting deprived districts in preparing water and sanitation plans to guide investments.

\section{Construction of new water points/ rehabilitating malfunctioning water systems}

Table 6.18 shows that new investments in water infrastructure have been improving over the years. There has, for example, been significant increase the number of new bore holes constructed (from 622 in 2002 to 2098 in 2004). Similarly, the number of small community and small town water systems has also been increasing, albeit from lower levels. 
Table 6.17: Achievements in water facility delivery, 2002 to 2004

\begin{tabular}{|l|l|l|l|}
\hline Facility & $\begin{array}{l}\mathbf{2 0 0 2} \\
\text { Achievements }\end{array}$ & $\begin{array}{l}\mathbf{2 0 0 3} \\
\text { Achievements }\end{array}$ & $\begin{array}{l}\mathbf{2 0 0 4} \\
\text { Achievements }\end{array}$ \\
\hline New boreholes constructed & 622 & 1290 & 2098 \\
\hline Boreholes rehabilitated & 407 & 115 & 85 \\
\hline New hand-dug wells & 65 & 61 & 64 \\
\hline Hand-dug wells rehabilitated & 2 & 6 & ---- \\
\hline $\begin{array}{l}\text { Small community pipe systems } \\
\text { completed }\end{array}$ & 4 & 19 & 40 \\
\hline $\begin{array}{l}\text { Small town pipe systems } \\
\text { completed }\end{array}$ & 25 & 46 & 57 \\
\hline
\end{tabular}

Source: 2004 Annual Report, Community Water and Sanitation

Implementation of Cabinet approved comprehensive sector policy (PRSC-3/MDBS)

Activities leading to the achievement of this indicator are all scheduled for mid-2005. In view of this, this indicator had not been achieved as by the end of 2004 .

Carrying out bydro-geological data base mapping for better targeting of investments

Project document has been completed and ready to be sighed by the GoG and CIDA. The project is expected to commence at the beginning of the Second Quarter of 2005

\section{Supporting deprived districts in preparing water and sanitation plans to guide investments}

The NDPC and CWSA have already completed the production of user-friendly manuals for preparing district water and sanitation plans. However, funds have not yet been secured to print and distribute manuals.

\section{Policy Recommendations}

The above analysis indicates that access to safe water has improved in the rural areas. Nevertheless, access to safe water remains low compared to the urban areas. Furthermore, only $47 \%$ of guinea worm endemic communities have access to safe water. A trend in access to adequate sanitation is difficult to discern due to lack of data.

The government will continue to pursue its policy of increasing access to safe water and adequate sanitation for rural people through:

- Promoting sector wide approach to rural water provision as a means of ensuring geographical equity in investment.

- Increasing levels of capital investment in the water sector, with emphasis in guinea worm endemic areas.

- Supporting District Assemblies in the preparation of water and sanitation plans

- Ensuring timely disbursement of Government component of funds to CWSA to ensure effective supervision and implementation of water and sanitation projects.

- Carrying out a national survey on sanitation conditions in the country for better targeting of investments.

- Strengthening collaboration between CWSA, Ministry of Health, and MLGRD in water delivery. 
Table 6.18: Summary of Status of Water and Sanitation Indicators in 2004

\begin{tabular}{|c|c|c|c|c|c|}
\hline Indicator & $\begin{array}{l}\text { Target } \\
2005\end{array}$ & 2002 & $\begin{array}{l}\text { Indicator } \\
\text { Status } 2003\end{array}$ & Status 2004 & Progress \\
\hline \multicolumn{6}{|l|}{ CORE INDICATORS (MTP) } \\
\hline $\begin{array}{l}\text { Percent of rural population with } \\
\text { access to safe water } \\
\text { CWSA }\end{array}$ & $46.0 \%$ & $40.0 \%$ & $46.4 \%$ & $51.7 \%$ & Good progress \\
\hline $\begin{array}{l}\text { Percent of rural population with } \\
\text { access to adequate sanitation } \\
\text { CWIQ }\end{array}$ & ---- & $45.8 \%$ & $55.0 \&$ & $\mathrm{n} / \mathrm{a}$ & \\
\hline \multicolumn{6}{|l|}{$\begin{array}{l}\text { Number of new functional water } \\
\text { systems. }\end{array}$} \\
\hline Boreholes & & 622 & 1290 & 2098 & On Track \\
\hline Protected wells & & 65 & 61 & 64 & Not much \\
\hline Pipe systems & & 29 & 65 & 97 & $\begin{array}{l}\text { change } \\
\text { Good progress }\end{array}$ \\
\hline $\begin{array}{l}\text { Reported number of guinea worm } \\
\text { cases }\end{array}$ & 0 & 5,545 & 8,290 & 7275 & $\begin{array}{l}\text { Slight } \\
\text { deduction in } \\
\text { the number of } \\
\text { cases }\end{array}$ \\
\hline \multicolumn{6}{|l|}{ PRSC-3/MDBS } \\
\hline $\begin{array}{l}\text { Cabinet approved comprehensive } \\
\text { sector policy implemented }\end{array}$ & - & - & - & $\begin{array}{l}\text { Activities leading } \\
\text { to the } \\
\text { achievement of } \\
\text { this indicator are } \\
\text { all scheduled for } \\
\text { mid-2005 }\end{array}$ & Not achieved \\
\hline $\begin{array}{l}\text { Hydro-geological data base } \\
\text { mapping for better targeting of } \\
\text { investments carried out }\end{array}$ & - & - & - & $\begin{array}{l}\text { Project document } \\
\text { has been } \\
\text { completed. }\end{array}$ & Not achieved \\
\hline $\begin{array}{l}\text { Deprived districts supported in } \\
\text { preparing water and sanitation } \\
\text { plans to guide investments }\end{array}$ & - & - & - & $\begin{array}{l}\text { The production } \\
\text { of user-friendly } \\
\text { manuals for } \\
\text { preparing district } \\
\text { water and } \\
\text { sanitation plans } \\
\text { completed. Plans } \\
\text { to train district } \\
\text { officers in the use } \\
\text { of manual far } \\
\text { advanced. }\end{array}$ & Good progress \\
\hline
\end{tabular}




\subsection{CITIZENS' ASSESSMENT OF PROVISION OF BASIC SERVICES}

A Participatory Monitoring and Evaluation (PM\&E) was undertaken in 2004 to obtain feedback information from local citizens about the extent to which the GPRS objective of enhancing access to basic services is being achieved at community level. The study offered opportunity to collect information on local people's assessment of basic services in the areas pertaining to the provision of safe drinking water; adequate sanitation facilities; health services and primary education.

Specifically the information was sought on access to facilities/services; usage of facilities/services' quality of services; adequacy of services; reliability of services; cost/affordability of services; responsiveness of service providers; and overall satisfaction with services.

In all 1000 households from four districts were selected for interview. The districts were randomly selected from a sampling frame of all the 110 districts stratified into three poverty panels. The poverty panels were defined as follows:

- Relatively non poor districts-those with less than $40 \%$ incidence of household poverty.

- Poor districts- those with $40 \%$ to $75 \%$ incidence of household poverty.

- Very poor districts-those with $75 \%$ or more incidence of household poverty.

In addition to the survey, eight focus group discussions (FGDs) composed of citizens and providers of services were held to complement the survey results. The FGDs were designed to provide information to (a) validate and support the results of the survey and (b) identify areas of immediate concern to households.

This section of the report provides a summary of the some of the key findings.

\subsubsection{Drinking Water and Sanitation}

\section{Access to Safe Drinking Water}

Majority of poor rural households $(56.2 \%)$ and very poor households $(62.3 \%)$ obtain their drinking water from boreholes. A significant proportion $(31.6 \%)$, however, still depends on unsafe sources of drinking water such as ponds, streams and unprotected wells. This is especially the case for households living in poor localities, which include households from guinea worm infected communities.

This observation was captured in quotable statements from Focus Group Discussions:

"To start with, I will talk about situation in this township. The standing pipes here have broken down for sometime now. (I mean more than five years ago). The central government should repair the pipes but it hasn't done it. The inhabitants of the town make a journey of about half $(1 / 2)$ a mile to fetch spring water and from unprotected wells that has been dug" (Assemblyman)

Although most households indicated that they obtain adequate drinking water all the time, the proportion of households reporting inadequate supply of drinking water increases as the household becomes poorer, especially among rural households. 
Just over half of the households interviewed reported that they have to pay for drinking water. The cost of water is sometimes a barrier to use of portable water for some poor and very poor household, forcing a number of them to use other sources that require no payments such as streams and ponds. This is clearly indicated below by a concerned mother in a focus group discussion.

We pay $\$ 200$ for a size 34 bucket of water. On the average a bousehold will buy water worth $\$ 1800$ per day. Sometimes it is difficult for us to pay for the cost of water. Livelihoods in the village are a bit tough/hard, even when we were paying $\$ 100$ for the same quantities of water. Some of us prefer going to the stream to fetch water. (mother).

One in five of households rated the quality of their drinking water as poor.

One FGD participant expressed grave concern about the health risks posed by poor quality of water.

"Unfortunately, the sources of drinking water in the whole community are not the best as at now. Health's wise, according to our records, there are many cases of typhoid. We have realized that it come from the sources of the water we drink in this community. There are hand-dug wells and spring water. We want to encourage people that at the earliest possible time this water problem in this area is solved" (Nursing Officer).

About four in ten of households have had problems with their water supply in the past year. The proportion reporting such problem was highest among very poor households. Among the major problems reported included dry pipes/taps/boreholes irregular water supply in the dry season, and mechanical faults/breakdowns.

$>$ Only about half of households interviewed rated the overall provision of water supply services in their communities, taking everything into consideration, as satisfactory.

\section{Access to Adequate Sanitation}

$>$ Access to adequate toilet facility seems to be poor in all the localities studied. As much as $40.5 \%$ of poor households and $80.9 \%$ of very poor households, for example, reported having no toilet facility at all.

$>$ The survey revealed that a large majority $(48.5 \%)$ of households have no access to proper refuse disposal facility and were very much concern about the problem. The situation tends to be worse in very poor localities, where over $70 \%$ of households indicated disposing their rubbish anywhere convenient. The following quotable statements from one district illustrate their concern:

"Refuse disposal is the most serious sanitation problem in this area.. When I assumed office the place where refuse were dumped looked like a mighty ant bill. The Assembly or the Administration organized some people to dig the refuse dump and send it the Akropong road. What I have realized is that since we eat everyday the refuse is building up again. At our last meeting we decided that the planning committee should find a permanent place where people will dump their refuse. So the committee is seriously finding a suitable place" (Planning Officer).

Overall, about $66 \%$ of households expressed dissatisfaction with the current state of sanitation facilities and services in their communities. 


\subsubsection{Health Services}

\section{Access to Health Services}

$>$ The survey showed most households use public hospitals/clinics to meet their health needs. This observation holds across poverty status and for urban and rural households.

$>$ About $71 \%$ of households across the three poverty groups indicated that distance to the nearest health facility was far, but it was worse for the poor $(76 \%)$. The results appear to suggest that health facilities are quite far from the homes of households, especially rural households.

$>$ A large percentage the non poor households (74.5\%) and poor households $(63.5 \%)$ indicated that they were able to pay for the cost of treatment any time they visited a health facility as against $50 \%$ of the very poor.

$>$ Contrary to a widely held belief that health professionals extort money from patients, an overwhelming majority $(80 \%)$ of households across the three poverty groups indicated that they do not pay any extra money when they visit a health facility. In cases where they had paid extra monies, about $70 \%$ offer these themselves.

\section{Quality of Health Care}

$>$ Concerning the quality of health care, majority of households considered the time waited before consultation together with the cost of treatment as big problems for them.

\section{Satisfaction with Health Care Provision}

$>$ Majority $(66.3 \%)$ of households rated the current health care provision in their communities as satisfactory. However, the proportion of households reporting satisfaction decreases as the household become poorer. An average of $75.8 \%$ of the non poor, $65.5 \%$ of the poor and $50.5 \%$ of the very poor were satisfied with health service provision in their communities. A rural mother who participated in the FGD stated her view on the state of health service provision in the following statement

We need a qualified doctor to come and man our health post. The place also has to be well stocked. We only have nurses who come from Cape Coast from time to time to man the place. We need electricity at the clinic. Due to the lack of personal and facilities at the clinic we do not patronize it and we go to the other health facilities

Another participant expressed his satisfaction as follows:

There is little improvement but it is not sufficient befitting a District capital like ours" (Assemblyman)

Significant proportion of the poor and the very poor that claimed not to be satisfied with the service provision cited distance to health facilities as the major reason. For the non-poor households the main reason was cost of treatment. : 


\subsubsection{Education}

\section{Access to Education}

Public primary and JSS schools dominate the educational sector across the three deprived regions. Private basic schools are more common in the urban communities.

> An overwhelming majority of rural households (80.7\%) and urban households (94\%) reported that permanent school structures have been constructed within their communities. This observation is indicative of increased investment in the construction of school structures under government and NGO initiatives.

$>$ Most rural and urban children walk to school since most of the schools are located less than 2 kilometres away from home. The proportion of children travelling more than 2 kilometres to school in rural and urban communities was 16.7\% and 29.3\% respectively.

\section{Cost of Education}

$>$ One of the most common reasons for low enrolment and high drop out in school is the issue of high direct cost of education. The survey revealed that as much as $78.9 \%$ of urban parents and $71.1 \%$ of rural households indicated that they are able to afford their children's school levies. Nevertheless, the study showed that about one in five of rural and urban parents considered the current school levies too high.

\section{Quality of Education}

With regard to quality of education received by their children, $83 \%$ of urban parents expressed satisfaction, compared with $63.1 \%$ of rural parents. Reasons for dissatisfaction of quality of education include inability of children to read, lack of textbooks/supplies and poor facilities. 


\section{CHAPTER SEVEN}

\section{GOVERNANCE}

\subsection{INTRODUCTION}

The attainment of relative macroeconomic stability, the prevalence of peace and security in the country, the increased involvement of civil society in policy formulation, implementation and monitoring, increasing private sector productivity and the growing confidence of Ghanaians are the results of improved good governance.

\subsection{REVIEW OF 2003 APR POLICY RECOMMENDATIONS}

Progress made towards the implementation of policy recommendations made in the 2003 APR is presented in Table 7.1 below.

Table 7.1: Status of APR 2003 Policy Recommendations

\begin{tabular}{|c|c|}
\hline APR 2003 Policy Recommendations & Status in 2004 \\
\hline $\begin{array}{l}\text { To promote a faster pace towards good governance, } \\
\text { greater dissemination of information about policies, } \\
\text { programmes and services should be mounted to } \\
\text { inform the public about their rights, their obligations } \\
\text { and the nature of services available. }\end{array}$ & $\begin{array}{l}\text { Several workshops and seminars were held across } \\
\text { the country by the NDPC and MDAs to } \\
\text { disseminate information about the rights and } \\
\text { responsibilities of citizens }\end{array}$ \\
\hline $\begin{array}{l}\text { Public fora to discuss issues of governance in relation } \\
\text { to justice, accountability and security need to be } \\
\text { intensified. In this sense, public fora such as the } \\
\text { Peoples' Assembly, which involves the President } \\
\text { interacting with ordinary citizens and which are } \\
\text { replicated at the regional and in some instances, the } \\
\text { district level, should be made a regular feature of the } \\
\text { governance programme. }\end{array}$ & $\begin{array}{l}\text { The Peoples' Assembly is still a regular feature of } \\
\text { governance programme }\end{array}$ \\
\hline $\begin{array}{l}\text { Also, good governance enhancers such as the 'Meet } \\
\text { the Press' series which affords the media the } \\
\text { opportunity to listen to and discuss issues with } \\
\text { incumbent ministers has to continue. Indeed, more use } \\
\text { will be made of the mass media as well as already } \\
\text { existing civil society groups in rural and urban areas, } \\
\text { including professional associations to discuss such } \\
\text { matters. }\end{array}$ & 'Meet the Press' series continued in 2004 \\
\hline $\begin{array}{l}\text { As a policy goal, the governance indicators will have to } \\
\text { be revised in future to present a more comprehensive } \\
\text { representation of all the other players. }\end{array}$ & $\begin{array}{l}\text { A workshop was organised in } 2004 \text { to review the } \\
\text { GPRS indicators and the results are being } \\
\text { incorporated in the GPRS Update. Key players } \\
\text { like CHRAJ, EC, Prisons, and governance } \\
\text { institutions are now involved in the GPRS Update }\end{array}$ \\
\hline $\begin{array}{l}\text { There is need to conduct research to establish the } \\
\text { system-wide impact of policy measures on improved } \\
\text { services by the district assemblies. }\end{array}$ & $\begin{array}{l}\text { A Participatory Monitoring and Evaluation was } \\
\text { conducted in six districts on the provision of basic } \\
\text { services namely; water, adequate sanitation } \\
\text { facilities, access to health services, primary } \\
\text { education and views on impact of macroeconomic } \\
\text { reforms on household livelihoods. } \\
\text { The Regional Poverty Monitoring Groups also } \\
\text { collected data on indicators measuring policy } \\
\text { impacts. }\end{array}$ \\
\hline $\begin{array}{l}\text { There is a need to strengthen government's capacity to } \\
\text { facilitate and set the development agenda to pave the } \\
\text { way for private sector and other social partners to fully }\end{array}$ & $\begin{array}{l}\text { Many capacity building programs have been } \\
\text { pursued }\end{array}$ \\
\hline
\end{tabular}




\begin{tabular}{|l|l|}
\hline APR 2003 Policy Recommendations & Status in 2004 \\
\hline contribute to the national development effort. & \\
\hline $\begin{array}{l}\text { There is need for stakeholder consultation towards } \\
\text { harmonising the existing separate indicators relating to } \\
\text { the NEPAD and the MDGs all of which have been } \\
\text { ratified by Parliament }\end{array}$ & $\begin{array}{l}\text { The current GPRS update is harmonising the } \\
\text { various indicators for purposes of promoting a } \\
\text { The APRM Governing Council undertook } \\
\text { nationwide consultations to prepare the country } \\
\text { report for the Peer Review }\end{array}$ \\
\hline
\end{tabular}

Almost all the specific benchmarks of good governance reviewed for 2004 registered positive developments as they did in the first two years of the implementation of the GPRS. The areas of policy focus that were reviewed were derived from the Medium Term Priorities in the GPRS, PRSC 3 and the MDBS. They cover a) Security and the Rule of Law and b) Decentralisation, c) Public Sector Reforms and Monitoring and Evaluation of policy implementation. These are summarised in Table 7.2 below.

\subsection{PROGRESS ON POLICY IMPLEMENTATION ON SECURITY AND RULE OF LAW}

\section{Policy Objective: Provision of Security and Strengthening the Rule of Law}

\subsubsection{Strengthening the Police}

\section{Equip and Train the Police}

Crime data for 2004 show that public safety has, to a large extent, improved. The levels of commonly committed crimes such as assault, stealing and fraud have not registered any significant growth in numbers. Fraud and stealing are on the decline, while assault cases rose only by 0.01 per cent $(3$ cases) over that of the previous year. For the major crimes such as Rape and defilement, the country has registered significant drops in reported cases.

Table 7.2: Summary of Progress on Indicators on the Security and the Rule of Law

\begin{tabular}{|c|c|c|c|c|c|}
\hline Indicator & Target & $\begin{array}{l}\text { Indicator } \\
\text { Level } \\
2002 \\
\end{array}$ & $\begin{array}{l}\text { Status } \\
2003\end{array}$ & $\begin{array}{l}\text { Status } \\
2004\end{array}$ & $\begin{array}{c}\text { Progress } \\
\text { toward target }\end{array}$ \\
\hline $\begin{array}{l}\text { Level of perceived corruption } \\
\text { in key GPRS functional areas }\end{array}$ & & & No survey conducted yet & & - \\
\hline \begin{tabular}{|l} 
Government Expenditure \\
Reports published \\
\end{tabular} & & & $\begin{array}{l}\text { Report published monthly } \\
\text { in gazette }\end{array}$ & & On track \\
\hline $\begin{array}{l}\text { Local safety and security } \\
\text { institutions in place }\end{array}$ & $\begin{array}{l}\text { 1:925 by } 2004 \\
\text { police/citizen } \\
\text { ratio }\end{array}$ & $1: 1142$ & \begin{tabular}{|l|}
$1: 1,121$ \\
police / citizen ratio
\end{tabular} & $1: 1055$ & $\begin{array}{l}\text { Not on track but } \\
\text { gradually moving } \\
\text { towards target }\end{array}$ \\
\hline $\begin{array}{l}\text { Dissemination of } \\
\text { Parliamentary debates on } \\
\text { poverty and development }\end{array}$ & & & $\begin{array}{l}\text { Dissemination occurred } \\
\text { through interaction with } \\
\text { unit committee members, } \\
\text { mass and print media. }\end{array}$ & & On track \\
\hline $\begin{array}{l}\text { Parliamentary Committee on } \\
\text { Poverty Reduction established }\end{array}$ & $\begin{array}{l}\text { Committee to be } \\
\text { set up in } 2002\end{array}$ & \begin{tabular}{|l|} 
Ad hoc \\
Committee \\
Established \\
and discussed \\
the GPRS \\
Document
\end{tabular} & $\begin{array}{l}\text { Ad hoc Committee in } \\
\text { place and met in } \\
\text { November. Efforts are } \\
\text { being made to make it a } \\
\text { Standing } \\
\text { Committee }\end{array}$ & $\begin{array}{l}\text { The committee } \\
\text { organized a workshop } \\
\text { from } 15^{\text {th }} \text { to } 17^{\text {th }} \\
\text { September } 2004 \text { to } \\
\text { discuss the } 2002 \text { and } \\
2003 \text { APR prior to } \\
\text { their being laid before } \\
\text { Parliament. }\end{array}$ & On track \\
\hline
\end{tabular}


Rape cases declined by almost 34 per cent over those of the preceding year, while defilement cases dropped by 6 per cent over the same period. The declining trend that began in 2003 with respect to robbery, was reversed with a 5 percent increase in robbery cases. Murder cases also went up by 4 percent. Police records show that such increases are attributable to increased infiltration of criminal elements from neighbouring countries that are experiencing political instability. The overall picture shows a marginal decline in the commission of crime in the country. An average of $-0.59 \%$ decline in offences committed is enough evidence that public safety is improving (See Table 7.3 below).

Table 7.3 Comparison of Summary of Offences Committed in 2003 and 2004

\begin{tabular}{|c|c|c|c|}
\hline Offence & 2003 & 2004 & $\%$ change \\
\hline Murder & 436 & 452 & 3.67 \\
\hline Attempted Murder & 58 & 69 & 18.97 \\
\hline Manslaughter & 20 & 104 & 420 \\
\hline Threatening & 21,496 & 22,915 & 6.60 \\
\hline Causing Harm & 3,020 & 3,002 & -0.60 \\
\hline Assault & 90,551 & 90,560 & 0.01 \\
\hline Robbery & 690 & 728 & 5.51 \\
\hline Stealing & 57,377 & 57,160 & -0.38 \\
\hline Fraud & 14,657 & 14,049 & -4.15 \\
\hline Unlawful entry & 375 & 786 & 109.6 \\
\hline Causing Damage & 10,237 & 10,601 & 3.56 \\
\hline Dishonestly receiving & 49 & 18 & -63.27 \\
\hline Abortion & 189 & 253 & 33.86 \\
\hline Rape & 952 & 631 & -33.72 \\
\hline Defilement & 2,001 & 1884 & -5.85 \\
\hline Possessing dangerous drugs & 146 & 19 & 86.99 \\
\hline Possessing Indian Hemp & 395 & 387 & -2.03 \\
\hline Abduction & 751 & 823 & 9.59 \\
\hline Extortion & 16 & 17 & 6.25 \\
\hline Forgery & 152 & 273 & 79.61 \\
\hline Falsification of Accounts & 7 & 1 & -85.71 \\
\hline Smuggling & 57 & 10 & -82.46 \\
\hline Possessing cocaine & 11 & 45 & 309.09 \\
\hline Possessing heroin & 7 & 26 & 271.43 \\
\hline Counterfeiting & 99 & 85 & -14.14 \\
\hline Issuing false cheque & 328 & 234 & -28.66 \\
\hline Child stealing & 48 & 69 & 43.75 \\
\hline Illegal gold mining & 11 & 4 & -63.64 \\
\hline Other offences & 22,533 & 20,136 & -10.64 \\
\hline Total & 226,669 & 225,341 & -0.59 \\
\hline
\end{tabular}

Source: Ghana Police Service 2004, Research Unit

Police/citizen relations continue to improve. A lot of anecdotal evidence (from radio phone-in programmes and newspaper articles and reports) point to increasing civilian confidence in the police. Information from civilians has improved the rate of solving criminal cases and has allowed for more expeditious dispensation of justice.

At the broader level, great progress was made in stabilising internal security. The security forces with the support of the entire citizenry succeeded in avoiding the major types of violence and instability that are usually associated with electioneering. The peaceful manner in which the 2004 elections were held attracted local and international commendation. This is evidence of government's commitment to the principles of good 
governance, improved coordination professionalism among the security forces and the growing desire of Ghanaians to comply with the rule of law. It also affirms the aspiration of the government to make Ghana a haven of peace in an unstable sub-region.

A strong correlation exists between a safe and secure political environment and a stable macro economy. The growing practice in good governance is impacting positively on economic indicators for 2004.

\section{Improving Police/Citizen Ratio}

The dividends of good governance cited above were achieved on the back of increased staff strength and of logistical support given to the Security forces. The government continued its programme of a comprehensive improvement of policing in the country. In this respect, the police service continued with the recruitment of additional service personnel and with the procurement of more vehicles and equipment. A total of 2,000 new police personnel were recruited in 2004 with 1,514 trained and passed out while the rest are still undergoing training. This brings the current staff strength of the police service to 17,058 men and women. The new recruitment in 2004 has raised the police citizen ratio from 1:1142 in 2002 to 1:1055 in 2004. The current ratio is slightly less than the target of 1:925 set for 2004. The shortfall has been attributed to the unanticipated increases in population as a result of the influx of refugees from neighbouring countries. To improve the police citizen ratio in the coming years, the Police Service has prepared a Strategic Medium Plan with a projected annual recruitment of 2000 young Ghanaians. The overall goal is to ensure effective policing. The preparatory work for the realisation of these targets has been initiated by the Police administration.

\section{Engender the and Police}

One major issue that attracted the attention of the current Police administration was the gender imbalance in the Service. There are a total of 2706 policewomen as against 14,352 policemen giving a ratio of 1:5. The most skewed rank is the DSP, which has a ratio of 1:24. For the officer Corp that is from the rank of Assistant Superintendent to the IGP there were 87 female officers as against 696 male officers giving us a ratio of 1:8. For the other rank the ratio of female to male is 1:21. To correct the skewed ratio, new recruitment and promotions now pay attention to gender considerations. Table 6.4 below shows the gender composition of the Ghana Police workforce in all the ranks.

Table 7.4 Gender Ratio of the Ghana Police Service as at December 2004

\begin{tabular}{|l|c|c|c|c|}
\hline RANK & FEMALE & MALE & RATIO F:M & TOTAL \\
\hline IGP & 0 & 1 & - & 1 \\
\hline D/IGP & 1 & 1 & $1: 1$ & 2 \\
\hline COMMISSIONER & 1 & 7 & $1: 7$ & 8 \\
\hline DEP/COMMISSIONE R & 1 & 9 & $1: 9$ & 10 \\
\hline ASST COMM & 3 & 46 & $1: 15$ & 49 \\
\hline CHIEF SUPT. & 21 & 117 & $1: 6$ & 138 \\
\hline SUPERINTENDENT & 16 & 79 & $1: 5$ & 95 \\
\hline DEP. SUPT. & 8 & 192 & $1: 24$ & 200 \\
\hline ASST. SUPT. & 36 & 244 & $1: 7$ & 280 \\
\hline C/INSPECTOR & 189 & 1210 & $1: 6$ & 1399 \\
\hline INSPECTOR & 237 & 1779 & $1: 8$ & 2016 \\
\hline SERGEANT & 594 & 3632 & $1: 6$ & 4226 \\
\hline CORPORAL & 381 & 1321 & $1: 4$ & 1702 \\
\hline LANCE CORPORAL & 321 & 1787 & $1: 6$ & 2108 \\
\hline CONSTABLE & 879 & 3927 & $1: 4$ & 4824 \\
\hline TOTAL & $\mathbf{2 7 0 6}$ & $\mathbf{1 4 , 3 5 2}$ & $\mathbf{1 : 5}$ & $\mathbf{1 7 , 0 5 8}$ \\
\hline
\end{tabular}

Source: Ghana Police Service 2004, Research Unit 
Figure 7.I below shows the ratio of male to female recruits in training at the various police training institutions in the country. It also shows efforts to bridge the gender gap among personnel. In all there are a total of 1266 recruits in training made up of 1018 males and 248 female given a gender ratio of 4:1 male - female.

Figure 7.1: Gender Distribution of Recruits Currently in Training

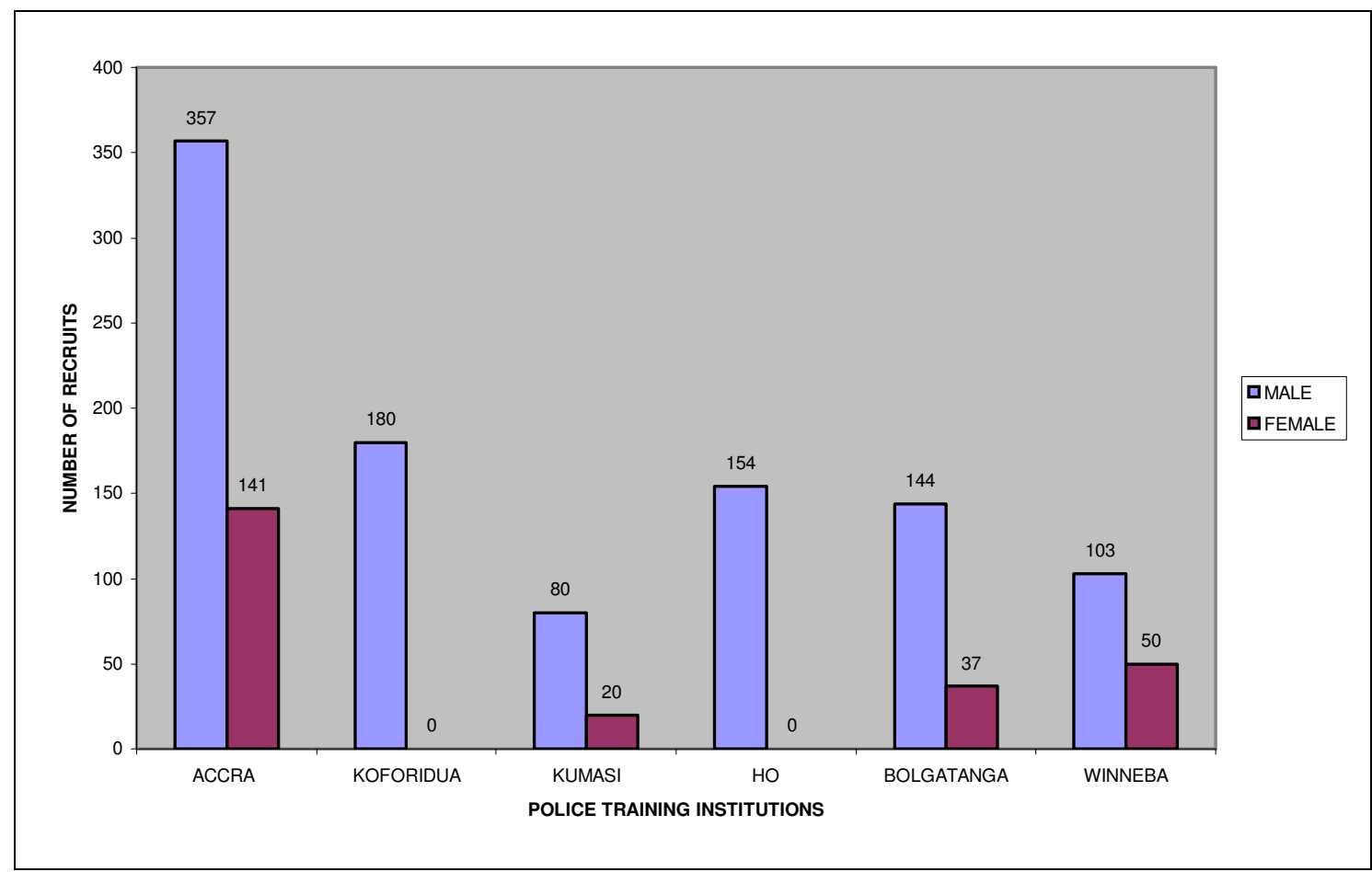

Source: Ghana Police Service 2004, Research Unit

WAJU in its bid to provide safety and security for women and children who suffer different kinds of violence continued efforts at bringing its mediation services closer to these victims of violence. WAJU expanded its offices in the country at the end of 2004 to many more towns at the sub-regional levels. However, WAJU is not adequately resourced to perform its mandate and to establish offices in all the districts. Currently it has only one official vehicle. The current coverage is as follows:

\begin{tabular}{|l|l|}
\hline Greater Accra & Eastern Region \\
\hline National WAJU Office & Koforidua Regional Office \\
\hline Regional WAJU Office & Nkawkaw Divisional Office \\
\hline Accra West Divisional Office & Oda Divisional Office \\
\hline Kpeshie Divisional Office & Kibi Divisional Office \\
\hline Odorkor District Office & \\
\hline & \\
\hline Ashanti & Western \\
\hline Kumasi Regional Office & Sekondi Regional Office \\
\hline & \\
\hline Brong Ahafo & Central \\
\hline Sunyani Regional Office & Cape Coast Regional Office \\
\hline Wenchi Divisional Office & Agona Swedru Divisional Office \\
\hline Berekum Divisional Office & \\
\hline
\end{tabular}




\begin{tabular}{|l|l|}
\hline & \\
\hline Volta & Tema \\
\hline Ho Regional Office & Tema Regional Office \\
\hline & \\
\hline Upper West & Upper East \\
\hline Wa Regional Office & Bolgatanga Regional Office \\
\hline & \\
\hline Northern & \\
\hline Tamale Regional Office & \\
\hline
\end{tabular}

The Community Policing concept aimed at specific security needs of communities was pursued further in 2004. This has resulted in the creation of 184 Neighbourhood Watch Committees.

\section{Equipment, Facilities and Logistics}

Twenty-nine new vehicles were acquired by the Police Service to augment its fleet of vehicles. Fifty Police Barracks were renovated in Accra, Volta and Western Regions and the Kumasi Police Training institution was renovated and converted into Basic Recruits Training School while another Basic Recruits Training School was established in Bolgatanga. Blocks of flats were completed for officers in Achimota, Cape Coast, Sekondi and Kumasi.

\section{Training}

In the bid to improve the professionalism of the Service, a number of personnel attended workshops within and outside the country. These courses are intended to redirect the thinking of Police personnel to appreciate and practice within the rule of law. The skills of detectives have been sharpened in the areas of crime intelligence gathering, crime management, crime scene investigation, confidence building and crime information analysis ${ }^{8}$. A total of 190 District and Unit Commanders were trained in Electoral Law, Electoral Procedure, Electoral Conflict Resolution and Management. Computer literacy skills are also being given to police personnel.

\subsubsection{Improving the Administration of Justice}

\section{Strengthen the Capacity of the Attorney Generals Department}

The Ministry of Justice has improved its staff position through recruiting new attorneys. It also provided additional training to its staff for better service delivery. During the year, 183 lawyers were trained by the General Legal Council, and called to the bar. The Ministry of Justice managed to recruit 8 new lawyers for the Attorney-General's office as against a target of 15 . Given the difficulty of attracting lawyers into the public service, this effort is commendable. As part of staff development, a number of serving attorneys benefited from external training programmes during the year. Fifty police Prosecutors were trained in modern methods of prosecution of cases.

In addressing issues concerning administration of justice, sight is often lost about the population of children in conflict/contact with the law. These are referred to as juvenile offenders, and normally come in contact with the legal system.

\footnotetext{
${ }^{8}$ Evidence of improved crime data collection and analysis is in the comprehensive nature of data submitted for the compilation of this report.
} 
The Department of Social Welfare (DSW) plays a very significant role in the processes of administering justice for this category of children from the time of arrest/inception of the case through trial, till the disposal of the case. In accordance with the Children's Act 560 of 1998 and the Juvenile Justice Act 653 of 2003, any process that aims at improving the Administration of Justice in Ghana equally needs to strengthen the DSW so as to protect the rights of children.

\subsubsection{Reducing Corruption}

\section{Strengthen Campaign against Corruption}

Anti-corruption initiatives have been undertaken by many public and private watchdog agencies. Some of the state institutions charged with anti-corruption mandates such as the Serious Fraud Office (SFO), the Commissioner of Human Rights and Administrative Justice (CHRAJ) and the Audit Service received various kinds of support during the year.

Unregulated and uncoordinated public procurement, poor financial administration and weak internal auditing are major avenues of misuse of public funds. Subsequent to the enactment of the Public Financial Management Laws- the Financial Administration Act, 2003, (Act 654), The Internal Audit Agency Act, 2003 (Act 658) and the Public Procurement Act, 2003, Act 663, a number of activities were undertaken in 2004 to give effect to the provisions of the laws. The Public Procurement and Internal Audit Boards were inaugurated on August 4, 2004 to lead the operationalisation of the Public Procurement and Internal Audit Agency Acts. The Boards undertook an extensive awareness programme for over 10,000 persons drawn from the Executive (including the President and his Ministers), Public and Private Sector and Development Partners.

Outside government, many institutions and organisations took up the anti-corruption challenge. The Centre for Democratic Development completed the diagnostic study on legal and institutional mandates of anti-corruption agencies and has submitted it for review. It plans to organise a workshop to discuss the findings after the review. Other organisations such as the Centre for Democratic Development (CDD), the Institute of Economic Affairs (who initiated the Freedom of Information Act and the Whistle Blowers' Protection Bill), Integrated Social Development Centre and the Institute of Democratic Governance, have been active in anti-corruption advocacy. Several Workshops on social accountability, good governance were held as part of efforts to minimise the spate of corrupt practices in the management of state resources. Proceedings of workshops and articles on corruption have been written and widely circulated for public consumption. The GACC organised a workshop to harmonise their Action Plan with the GPRS.

Civil Society Organisations in governance and anticorruption embarked on research, round table discussions, public forums and debate to sensitise the public on anticorruption issues. They also monitored the abuse of incumbency and other corruption practices in the 2004 polls. There was also public education in the local and district levels on the need to hold government accountable. For the 2004 elections CSOs embarked on election observation programs, developed code of ethics for political parties all intended to foster transparency and level playing field. 
Various Investigative journalism in the print and electronic media aimed at keeping public officials in check has now become common practice. All these efforts have created a more congenial environment for public discourse on anti-corruption issues.

\subsubsection{Support to Parliament}

\section{Provide support services to Parliament}

Apart from the normal support under the government public expenditure allocations, Parliament received various kinds of support from other quasi-state and non-state institutions. The National Governance Programme, the Centre for Democratic Development, The Parliamentary Centre, Women's Groups and the Institute of Democratic Governance all provided capacity building support to parliament. Programmes such as Analysing the Public Budget, Gender Budgeting, Social Accountability and Understanding the Domestic Violence Bill were all organised during the year. The National Governance Programme assisted Parliament with resources to print the hansards. The hansards are now available for sale.

Being an election year, 2004 provided a unique opportunity for high frequency interaction between individual members of parliament and their constituents. Given the level of competition generated by the electioneering campaign, all sitting MPs visited all corners of their constituencies on numerous occasions to explain both their personal contributions to the work of Parliament and what parliament as an institution did during the year. Some MPs bought space on radio stations to discuss their roles as legislators and received feedback from listeners. MPs thus accounted for their stewardship and brought the work of Parliament to the attention of their constituents.

A total of 28 Bills were brought before Parliament. Appendix 2 shows the status of actions on these the bills.

\section{Policy Recommendations}

The programme for involving communities in local policing is yet to be formalized and adequately resourced. Neighbourhood Watch Committees should be instituted as part of the general crime prevention policies.

The policy of authorizing private security agencies to perform some police duties should be reviewed with the view to defining the limits of their operation to the provision of private security to private property only. The policy should also indicate a period of phasing out the patrol duties of these agencies.

Engendering recruitment and promotions within the police service is a positive development that needs to be entrenched by developing and adopting a gender policy for the police. The policy should be introduced to the other security agencies. This will require improving facilities that cater for the needs of women officers and women offenders. The WAJU should be adequately resourced and mainstreamed into the Police Service.

To further enhance the democratic process the frequency of interaction between members of Parliament and their constituents should be increased. Towards this end 
factors inhibiting regular interaction between the MPs and their constituents such as inadequate resources should be removed as a matter of policy.

Consideration should be given to the hiring of additional attorneys in the Ministry of Justice in order to increase the capacity to cope with the back-log of cases under the free legal aid scheme. The reluctance of newly qualified lawyers to enter the public service is a result of both low remuneration and the high cost of acquiring the professional qualification. As new policy initiatives, there is the need to improve the remuneration of lawyers or provide scholarships to lawyers -in- training to attract their entry and retention to the Ministry. The Legal Aid Board should be adequately resourced to defend accused persons especially the poor.

The Department of Social Welfare (DSW) is constrained by limited manpower and logistics in the performance of its duties and thus unable to provide effective and quality services to juvenile offenders. Measures to improve Justice Administration in Ghana will have to consider strengthening the DSW to effectively manage juvenile crime and rehabilitation.

\subsection{Decentralisation}

Policy objective 1: Accelerate the implementation of Decentralisation (GPRS)

Policy objective 2: Implement framework for decentralized delivery of local public services (MDBS 2005/PRSC 3)

The key indicators to be measured under decentralisation this year which in reality, are an extension of the benchmarks for 2003, are: a) Increasing the DACF from 5.0\% of Tax revenue to $7.5 \%$, b) Initiating implementation of the Local Government Service Act, 2003 (Act 656) and c) Strengthening institutional processes between Metropolitan, Municipal and District Assemblies (MMDAs) and civil society.

\section{Outcomes of Interventions}

Even though government was unable to increase the DACF from 5 per cent to the targeted 7.5 per cent of tax revenue, the districts received nominal increases in levels of government funding. For instance in 2003, DACF released a total of $\phi 449,287,329,178$ to all the regions. This increased to $\$ 771,454,802,005$ in 2004 . In addition to the ceded revenue from the DACF, all districts benefited from the releases under the HIPC Initiative during the year. This and other poverty related allocations greatly augmented the resources available to the MMDAs for funding development projects. Government moved to consolidate the decentralisation programme further by creating 28 new districts during the year. This has brought local governance closer to many more Ghanaians and had reduced the difficulties related to administering large and unwieldy districts. It also increased the opportunity of citizens of the new districts to participate directly in political decision-making process. All the new districts put up candidates for the December Presidential and Parliamentary election and now have elected representatives in the legislature. 
Table 7.5 Summary of Progress - Decentralisation

\begin{tabular}{|c|c|c|c|c|c|}
\hline Indicator & Target & $\begin{array}{l}\text { Indicator } \\
\text { Level } \\
2002\end{array}$ & $\begin{array}{l}\text { Status } \\
2003\end{array}$ & $\begin{array}{l}\text { Status } \\
2004\end{array}$ & $\begin{array}{l}\text { Progress } \\
\text { toward } \\
\text { target }\end{array}$ \\
\hline $\begin{array}{l}\text { Composite budget developed } \\
\text { and submitted }\end{array}$ & & $\begin{array}{l}\text { Yet to be } \\
\text { implemented }\end{array}$ & $\begin{array}{l}\text { Action was initiated in } 3 \text { pilot } \\
\text { districts - Dangme East and } \\
\text { West and Akuapem North }\end{array}$ & $\begin{array}{l}\text { The integrated planning and } \\
\text { composite budgeting pilot is being } \\
\text { implemented according to } \\
\text { schedule. In addition to the } 3 \\
\text { districts where the pilot is currently } \\
\text { being implemented, } 22 \text { more } \\
\text { districts have been tentatively } \\
\text { selected ( } 2 \text { from each region, but } \\
\text { excluding the newly created } \\
\text { districts and the districts that these } \\
\text { were carved from.) }\end{array}$ & On track \\
\hline $\begin{array}{l}\text { Democratic effectiveness of } \\
\text { the District Assemblies }\end{array}$ & & & $\begin{array}{l}\text { All DAs meet regularly as } \\
\text { enshrined in the LIs. }\end{array}$ & $\begin{array}{l}\text { All DAs meet regularly as } \\
\text { enshrined in the LIs. }\end{array}$ & \\
\hline $\begin{array}{l}\text { DACF increased to } 7.5 \% \text { of } \\
\text { Tax revenue }\end{array}$ & & $5 \%$ & $5 \%$ & $5 \%$ & Not done \\
\hline \begin{tabular}{|l} 
Local Government Service \\
Bill passed
\end{tabular} & Pass Bill & $\begin{array}{l}\text { Bill before } \\
\text { parliament }\end{array}$ & $\begin{array}{l}\text { Bill passed on } 18^{\text {th }} \text { July } 2003 \\
\text { and gazetted on } 31 / 12 / 03\end{array}$ & Bill Passed in 2003 & Done \\
\hline $\begin{array}{l}\text { Institutional processes } \\
\text { between DAs and CSOs } \\
\text { strengthened }\end{array}$ & & & $\begin{array}{l}\text { Institutional processes being } \\
\text { strengthened }\end{array}$ & & \\
\hline $\begin{array}{l}\text { Operationalize the Local } \\
\text { Government Service act by } \\
\text { establishing its governing } \\
\text { body (Local Government } \\
\text { Council and Secretariat), by } \\
\text { preparing conditions and } \\
\text { scheme of service and by } \\
\text { developing guidelines and } \\
\text { modalities for }\end{array}$ & & & 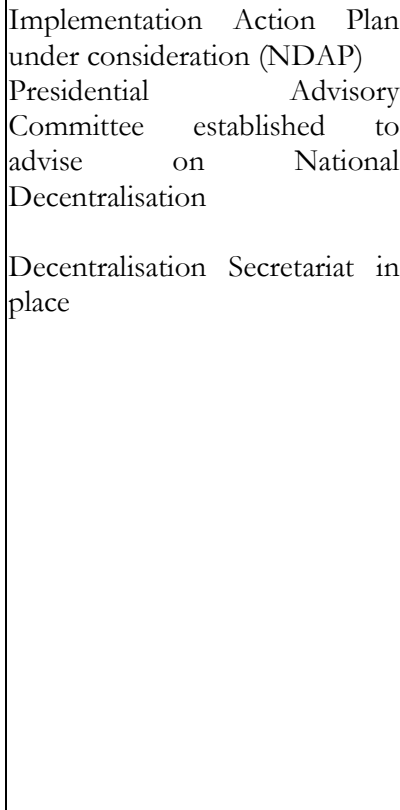 & $\begin{array}{l}\text { In line with the requirements of } \\
\text { Clause } 5 \text { of the LGS-Act } 656 \text {, the } \\
\text { governing body for the Service, } \\
\text { including its Head, was appointed } \\
\text { in September and inaugurated in } \\
\text { November. An appropriate } \\
\text { organizational/ functional structure } \\
\text { for the Council's Secretariat is } \\
\text { under preparation. } \\
\text { Preparation of the conditions and } \\
\text { scheme of service for the LGS has } \\
\text { also been initiated } \\
\text { In line with the requirements of } \\
\text { clauses } 16-24 \text { of the LGS Act } 656, \\
\text { preparations for the establishment } \\
\text { of consolidated departments have } \\
\text { been initiated and are ongoing. } \\
\text { Presidential Committee } \\
\text { Decentralisation was approved in } \\
2004 \text {. }\end{array}$ & On Track \\
\hline
\end{tabular}

\section{Nature of Interventions}

The National Governance Programme provided funds for the provision of the software on Geographic Information Systems to the Electoral Commission which aided the Commission in the demarcation of 30 new constituencies and 28 new districts.

Policy Objective: Implement framework for decentralized delivery of local public services 


\section{Operationalize the Local Government Service Act}

When measured against political, legal, administrative and fiscal indicators, Ghana ranks amongst the most decentralised countries in Africa9. At the same time, the decentralisation process has been characterised by a relative lack of policy coherence and strategic direction, and lack of harmonisation of various donor supported interventions. As a result, implementation has not been optimal, including the use of human and financial resources. The implementation of the decentralisation policy has been constrained by conceptual differences by various sectors, weak intersectoral collaboration, inadequate managerial and technical capacity, weak co-ordination of donor/NGO/CSO- support, weak monitoring capacity, budgetary and logistical constraints, and attitudinal problems. 10

Government responded to this situation with the formulation of the NDAP 11, a threeyear, rolling policy framework that provides strategic direction as well as a common platform for donor coordination and harmonisation. Since the NDAP was endorsed by Cabinet in February 2004, its implementation has been coordinated by the Decentralisation Secretariat (MLGRD), thereby assisted by a small but growing number of DP's. The Secretariat will service Inter-sectoral Committee and the Presidential Advisory Committee on Decentralisation.

The NDAP is firmly anchored in the GPRS and seeks to consolidate and build on past achievements on the side of both Government and DP's. Key areas are: policy coordination and management, funding of local government, capacity building, and the strengthening of local governance partnerships, including the role of Traditional Authorities. With its current emphasis on harmonisation and systems development, the NDAP aims to pave the way for structural reforms and the eventual development of a sector-wide approach to decentralisation.

As required by the provisions of the Local Government Service Act, the Ministry of Local Government and Rural Development (MLGRD) established a 15-member Local Government Service Council and a Technical sub-Committee of the Council. The subCommittee reviewed and updated the functions of the MMDAs as a preparation towards a stakeholders' consultative programme.

\section{Implement the National Decentralization Action Plan, with integrated planning and composite} budgeting in at least 25 districts.

The integrated planning and composite budgeting pilot was implemented according to schedule. In addition to the 3 districts where the pilot was initiated, 22 more districts have been tentatively selected ( 2 from each region, but excluding the newly created districts and the districts that these were carved from) to implement the programme. The Local Government Act, 1993, (Act 462) and the Local Government Service Act, 2004 (Act 656) with Legislative Instruments, all serve to deepen decentralisation and to ensure that authority, power and functions have been devolved to DAs. However the financial administration have not been fully decentralised; with some decentralised departments still holding on to their budgets at the centre

\footnotetext{
${ }^{9}$ OECD, Policy Insights No. 5, 2005

${ }^{10}$ NDAP 2004-2006, Ministry of Local Government and Rural Development (page 6); Comparative assessment of local government capacity building initiatives and institutional service providers 1999-2004, MLGRD 2004; PSIA Enhancing Capacity for Pro-Poor Decentralization; Resource Allocation, Mobilization, Management and Capacity Building at District Level, 2005

${ }^{11}$ NDAP 2004-2006, Ministry of Local Government and Rural Development (page 8)
} 
As a step towards bringing local governance closer to the citizenry, 13 sub-metro offices were inaugurated in 2004.

With respect to civic engagement with local governance, the evidence points to increased cooperation. District Assemblies have created opportunities for civil society representatives to participate in the design, management and monitoring of development projects. Local NGOs such as the SEND Foundation, the Northern Network of NGOs, ISODEC, are involved in the monitoring of the use of the HIPC funds and DACF. The findings are shared with the broader population. Other international NGOs are involved in capacity building projects for officials of MMDAs and of district sector representatives as well as in providing budget support for district projects. NGOs such as SNV, Actionaid, CARE Ghana, Plan Ghana VSO, etc are actively working with MMDAs to extend development to reach communities, thus complementing the development efforts of the MMDAs. IBIS provided training for women Assembly members as well as for Unit committee members. The results of these programmes and of the new initiatives piloted by these NGOs are available for replication. Evidence of best practices also constitutes key elements of broader policy formulation.

\section{Policy Recommendations}

There is need to collate the results of development initiatives by civil society groups that have yielded positive results in liquidating the poverty status of some communities into development policy framework. A formal institutional arrangement is need to ensure that the development experiences of civil society, development partners and government are harmonized. It is cost-effective and time-efficient.

The Ministry of Local Government and Rural Development and the Department of Social Welfare should ensure that the child panel system is opertionalised.

There are many players involved in trying to improve governance and management of the district economy. The RCCs / RPCU should effectively exercise their role of coordinating development programmes in the regions to ensure proper facilitation of donor activities and to avoid duplication and ensure more efficient use of resources. This will also ensure smooth coordination amongst Donors and by the RCC and provide a forum for open interaction among stakeholders

An association of NGO's should be formed in each region to enhance harmonization of their activities and provide a one-stop shop for supporting development programmes with District Assemblies.

With Decentralisation being pursued so vigorously through the NDAP, and with the huge resources being transferred to districts, it is necessary to urgently implement the public-private partnership for local governance program by encouraging DAs to engage civil society and the private sector in the affairs of Assemblies.

Reports received from the district indicate that Zonal, Area, Urban and Town Councils are not effectively operational except in the Upper West and Volta Regions where support from development partners has made the sub-districts structures fully functional. The MLGRD and the Ministry of Finance should come to the aid of the districts and provide them with funds in these start-up years to pay staff of the sub-district structures 
in order that the resources put into the construction of Area Councils across the country do not go to waste.

The plan to increase the DACF from 5.0 per cent of national revenue to $7.5 \%$ should be implemented to make more resources available for development work at the local government level.

MLGRD and NDPC (Presidential Committee and the ME Cross Sectoral Committee as established within the NDAP ${ }^{12}$, or the ME GPRS Committee once established) should guide various ME initiatives and DP support, and clarify and guide various roles and communication channels at various levels, to ensure harmonization of ME systems and to ensure effective strengthening of the organisations.

More guidance and support should be provided for gender sensitive analysis, planning, budgeting and monitoring at district, regional and national levels (MOFEP, MOWAC, MLGRD, NDPC). Lessons learned from existing programs to promote gender equity (eg DISCAP) should be shared by MLGRD.

\subsection{PUBLIC SECTOR REFORMS}

\section{Improving performance of the public sector}

\section{Policy Objective: Implement refocused public sector reform}

A strong relationship exists between the tenets of good governance and an efficient, well motivated public sector. Government objective is to place state institutions in a strategic position to enable them discharge their mandate in a manner that promoted the realisation of the good governance principles of effectiveness, transparency and

Table 7.6: Summary of Progress - Public Sector Reforms

\begin{tabular}{|l|l|l|l|}
\hline Indicator & Target & $\begin{array}{l}\text { Status } \\
2003\end{array}$ & $\begin{array}{l}\text { Status } \\
2004\end{array}$ \\
\hline $\begin{array}{l}\text { A new HR structure at } \\
\text { OHCS in place with the } \\
\text { capability to deliver } \\
\text { improved HR management } \\
\text { professional } \\
\text { functions across the Civil } \\
\text { Service }\end{array}$ & & $\begin{array}{l}\text { Procurement procedures completed to enable the } \\
\text { development of the plan for implementation of finalized } \\
\text { PSR strategy for the Civil Service including an HR } \\
\text { framework as defined in the strategy document. } \\
\text { Project document is expected to be ready at the end of } \\
\text { May 2005. }\end{array}$ \\
\hline $\begin{array}{l}\text { Operational Communication } \\
\text { Unit in PSR secretariat }\end{array}$ & $\begin{array}{l}\text { Effective } \\
\text { communication } \\
\text { strategy in place. }\end{array}$ & $\begin{array}{l}\text { An operational Communication Unit has been established } \\
\text { at the PSR Secretariat } \\
\text { An effective Communication Strategy has been developed } \\
\text { to drive the implementation of the PSR agenda. }\end{array}$ \\
\hline $\begin{array}{l}\text { Commence organizational } \\
\text { restructuring of the civil } \\
\text { service; }\end{array}$ & $\begin{array}{l}\text { Draft proposal to Cabinet on the establishment of an } \\
\text { institutional home for the PSR is being finalized. }\end{array}$ \\
\hline $\begin{array}{l}\text { Establish a regulatory } \\
\text { framework for SAs and } \\
\text { continuing the restructuring } \\
\text { of selected SAs }\end{array}$ & $\begin{array}{l}\text { Draft of Subvented } \\
\text { Agencies Reform Bill } \\
\text { SARB) submitted to } \\
\text { cabinet. }\end{array}$ & $\begin{array}{l}\text { Draft Job descriptions for Chief Director positions have } \\
\text { been prepared }\end{array}$ \\
\hline $\begin{array}{l}\text { A draft Sub vented Agencies Reform Bill (SARB) has been } \\
\text { prepared. It is being reviewed for submission to Cabinet }\end{array}$ \\
\hline
\end{tabular}

\footnotetext{
${ }^{12}$ NDAP 2004-2006, Ministry of Local Government and Rural Development (page 17)
} 
accountability engendering the right context for other stakeholders- the private sector and civil society to participate fully in the national development endeavour. Years of neglect allowed the public service to grow out of proportion to the resources available. A shortage of expertise in critical areas of public administration such as policy analysis, strategic planning and financial management became an endemic problem of the public service. The service consequently grew weak with a characteristically low morale. A weak public administration system poses a great threat to government's capacity to deliver development to its citizens and pushes the state down a path of ultimate dysfunction. The policy to remake the public service in response to the national development imperatives was pursued with a sense of mission in 2004. The Office of the Senior Minister which has oversight responsibility for the Public Sector Reform (PSR) undertook a review of the entire range of programmes with a view to injecting dynamism into the reform. In the main, the PSR involved strengthening the ability of public office holders to deliver service to the broader Ghanaian population more effectively. The specific reform efforts are discussed in Section 6.3 below.

\section{Outcome of Interventions}

The (PSR) initiatives have changed the image, orientation and delivery capabilities of the public service. Noticeable changes brought about by the PSR include an internalisation and the practice of core public administration values and principles of transparency, competency, accountability, responsiveness and cost-effectiveness. Also it is evident that the leadership of the public service are showing the determination to ensure a 'value for money public service', promote proper husbandry of public resources, think and act strategically and employ performance-driven service delivery.

\section{Specific Policy Interventions}

The Office of the Senior Minister developed a framework for re-examining and making proposals for appropriate retooling of the public sector. Some implementing aspects of the proposed reforms, have realigned their institutional objectives with that of the new proposals and vision.

The Civil Service received ICT training and facilities during the year. This forms part of the effort to modernise the service for efficient and effective service delivery.

The government continued its programme of establishing of new records management systems in some Ministries and Departments in Accra. And record management in Audit Service, CHRAJ, Ministries of Finance \& Economic Planning, Education \& Sports, Interior, Energy, Local Government \& Rural Development, and 4 Regional Coordinating Councils have been strengthened and restructured with new systems installed.

Five workshops were held for Chief Directors, Directors of MDAs and Regional Coordinating Directors on Civil Service Reforms. Regular collegial consultative arrangements have been introduced for the leadership of the service. This arrangement enables the leadership of the Service to backstop colleagues in other MDAs and receive support through the same consultative channels.

\section{Policy Recommendations}

Major policy initiatives are contained in the PSR under the supervision of the Senior Minister. Implementation of these would be hastened in the coming year for purposes of achieving an optimum functioning public sector. 
The programme to improve the remuneration in the public sector under the Public Sector Reform programmes would be implemented alongside the other components.

In the interest of promoting good governance, the Public Sector Reform programme should strengthen the public sector to step up its oversight responsibility of State Owned Enterprises.

Table 7.7: Summary of Progress - Monitoring and Evaluation

\begin{tabular}{|l|l|l|l|l|}
\hline Indicator & $\begin{array}{l}\text { Indicator Level } \\
2002\end{array}$ & $\begin{array}{l}\text { Status } \\
2003\end{array}$ & $\begin{array}{l}\text { Status } \\
2004 \\
\text { toward } \\
\text { target }\end{array}$ & On track \\
\hline $\begin{array}{l}\text { Policy Feedback } \\
\text { from M\&E system }\end{array}$ & $\begin{array}{l}2002 \text { Annual Progress } \\
\text { Report, 2003 APR prepared. } \\
\text { Communication } \\
\begin{array}{l}\text { Strategy, Quarterly } \\
\text { Bulletin, 2002 APR was } \\
\text { used to influence 2004 } \\
\text { budget }\end{array}\end{array}$ & $\begin{array}{l}\text { 2004 APR prepared. } \\
\text { Social Protection strategy and Citizens } \\
\text { Report Card on basic services and } \\
\text { macroeconomic stability were } \\
\text { prepared in 2004 }\end{array}$ \\
\hline
\end{tabular}

\section{Policy Objective: Strengthen Monitoring and Evaluation system of the GPRS}

The preparation of the 2005 budget involved the use of the APR in the majority of the budget preparation activities. The outlook of the 2005 budget was informed by the 2003 APR and the PSIAs. The macro framework as provided by the budget is been established to strengthen M\&E activities at the regional and district levels. The Development Dialogue series continued in 2004. Some Initiatives were consistent with the GPRS targets. The technical steering committee on GPRS Communication (MDAs and DPs) delivered a Training of Regional Trainers Workshop on the GPRS Communication in 2004. The purpose was to create awareness and commitment on GPRS and to create mechanisms for consultations and feedback in regions and districts via trained trainers. Simplified versions of the GPRS published in seven local languages have been disseminated. The GPRS and APR were discussed extensively during the National Economic Dialogue, the event was well covered live on television, radio and by the press. The Strategic Environmental Assessment (SEA) of the GPRS was discussed extensively at a Ministerial Conference. A number of National Inter-Agency Poverty Monitoring Group meetings have been held to review the use of the 2003 APR and to support the preparation of the 2004 APR. Representatives of Civil Society Organisations (CSOs) have been included in the (NIAPMG). Regional Poverty Monitoring Groups were inaugurated in 2004. NDPC launched a website on the GPRS, and the first documents were posted. Also a participatory Monitoring and Evaluation exercise was undertaken to complement the results of the 2003 APR in 2004 (See chapter 1 for details).

The GPRS M\&E Technical Committee has not been established yet. Greater coordination and harmonisation is needed for $\mathrm{M} \& \mathrm{E}$ activities between the core organisations at the central level (MOFEP, NDPC, OOP, MLGRD, GSS, MOWAC, and OHCS), with better information flows and incentives for M\&E to improve GPRS monitoring and evaluation. The National Decentralisation Action Plan (NDAP) and the various committees established under its umbrella (the Presidential Advisory Committee on Decentralisation, which was inaugurated in 2004 and the Inter Sectoral Working Group) have important roles to play in this. 
Table 7.8: Summary of Priority Indicators - Governance

\begin{tabular}{|c|c|c|c|c|c|c|}
\hline Program Area & Objectives and Indicators & Target & $\begin{array}{l}\text { Indicator Level } \\
2002\end{array}$ & $\begin{array}{l}\text { Indicator Level } \\
2003\end{array}$ & $\begin{array}{l}\text { Indicator Level } \\
2004\end{array}$ & $\begin{array}{l}\text { Progress towards } \\
\text { Target }\end{array}$ \\
\hline \multicolumn{7}{|l|}{ MTP } \\
\hline \multirow[t]{5}{*}{$\begin{array}{l}\text { Security and the } \\
\text { Rule of Law }\end{array}$} & $\begin{array}{l}\text { Local safety and security in } \\
\text { place. Police citizen ratio }\end{array}$ & 1:925 by 2004 & $1: 1142$ & $1: 1121$ & $1: 1055$ & \\
\hline & Equip and train the police & & $\begin{array}{l}100 \text { vehicles in } \\
2000\end{array}$ & $\begin{array}{l}470 \text { vehicles procured, } 854 \\
\text { recruited \& trained }\end{array}$ & $\begin{array}{l}\text { A total of } 2,000 \text { new police } \\
\text { personnel were recruited with } \\
1,514 \text { trained and passed out } \\
\text { while the rest are still } \\
\text { undergoing training } \\
29 \text { additional vehicles were } \\
\text { procured for the police in } \\
2004\end{array}$ & On track \\
\hline & $\begin{array}{l}\text { Strengthen the capacity of the } \\
\text { Attorney -Generals' office }\end{array}$ & & & $\begin{array}{l}\text { Training and office equipment } \\
\text { provided for AGs office }\end{array}$ & $\begin{array}{l}8 \text { lawyers as against a target of } \\
15 \text { were recruited in } 2004 . \\
\text { External } \\
\text { programmes were organised } \\
\text { for some }\end{array}$ & \\
\hline & $\begin{array}{l}\text { Strengthen campaign against } \\
\text { corruption }\end{array}$ & & & $\begin{array}{l}\text { Coalition Against Corruption } \\
\text { recruited Executive Secretary } \\
\text { and other staff and procured } \\
\text { office equipment }\end{array}$ & & \\
\hline & $\begin{array}{l}\text { Provide support services to } \\
\text { Parliament }\end{array}$ & & & $\begin{array}{l}\text { Training, ICT equipment and } \\
\text { equipment for radio station } \\
\text { provided }\end{array}$ & & \\
\hline \multirow[t]{3}{*}{ Decentralisation } & $\begin{array}{l}\text { DACF increased to } 7.5 \% \text { of Tax } \\
\text { revenue }\end{array}$ & $7.5 \%$ & $5 \%$ & $5 \%$ & $5 \%$ & Not done \\
\hline & $\begin{array}{l}\text { Local Government Service Bill } \\
\text { passed }\end{array}$ & Pass Bill & $\begin{array}{l}\text { Bill before } \\
\text { parliament }\end{array}$ & $\begin{array}{l}\text { Bill passed on } 18^{\text {th }} \text { July } 2003 \\
\text { and gazetted on } 31 / 12 / 03\end{array}$ & & Done \\
\hline & $\begin{array}{l}\text { Institutional processes between } \\
\text { DAs and CSOs strengthened }\end{array}$ & & & $\begin{array}{l}\text { Institutional processes being } \\
\text { strengthened }\end{array}$ & & \\
\hline
\end{tabular}




\begin{tabular}{|c|c|c|c|c|c|c|}
\hline Program Area & Objectives and Indicators & Target & $\begin{array}{l}\text { Indicator Level } \\
2002\end{array}$ & $\begin{array}{l}\text { Indicator Level } \\
2003\end{array}$ & $\begin{array}{l}\text { Indicator Level } \\
2004\end{array}$ & $\begin{array}{l}\text { Progress towards } \\
\text { Target }\end{array}$ \\
\hline \multicolumn{7}{|l|}{$\begin{array}{ll}\text { MDBS } & 2005 / \\
\text { PRSC } 3 & \\
\end{array}$} \\
\hline \multirow[t]{2}{*}{$\begin{array}{l}\text { Improving } \\
\text { Governance and } \\
\text { Public Sector } \\
\text { Management }\end{array}$} & $\begin{array}{l}\text { Improved governance and } \\
\text { public accountability } \\
\text { Continue implementation of } \\
\text { activities aimed at reducing } \\
\text { fraud and combating corruption } \\
\text { Carry out diagnostic study on } \\
\text { legal and institutional mandates } \\
\text { of anti-corruption agencies, } \\
\text { discuss results through a } \\
\text { consultative process and } \\
\text { implement agreed } \\
\text { recommendations } \\
\text { Review existing legislative } \\
\text { framework governing anti- } \\
\text { corruption with a view of } \\
\text { codification and bringing about } \\
\text { conformity with international } \\
\text { standards. }\end{array}$ & $\begin{array}{l}\text { Diagnostic Study, } \\
\text { including a review of the } \\
\text { legislative framework, } \\
\text { finalized and results } \\
\text { discussed in consultative } \\
\text { process with stakeholders. } \\
\text { Ministry of Justice to } \\
\text { present recommendations } \\
\text { to Cabinet; and begin } \\
\text { implementation of those } \\
\text { recommendations that do } \\
\text { not need Cabinet } \\
\text { endorsement. }\end{array}$ & & & & \\
\hline & $\begin{array}{l}\text { Disseminate the results of the } \\
\text { APRM initiative widely }\end{array}$ & $\begin{array}{l}\text { Four national studies } \\
\text { distributed widely. }\end{array}$ & & & $\begin{array}{l}\text { Studies done and results sent } \\
\text { to eminent members in South } \\
\text { Africa for comments }\end{array}$ & \\
\hline & $\begin{array}{l}\text { Implement framework for } \\
\text { decentralized delivery of local } \\
\text { public services } \\
\text { Implement the National } \\
\text { Decentralization Action Plan, } \\
\text { with integrated planning and } \\
\text { composite budgeting in at least } \\
25 \text { districts }\end{array}$ & $\begin{array}{l}\text { Composite budgeting } \\
\text { documents of } 25 \text { districts; } \\
\text { Process description for } \\
\text { each of the } 25 \text { budgets } \\
25 \text { District development } \\
\text { plans }\end{array}$ & $\begin{array}{l}\text { Yet to be } \\
\text { implemented }\end{array}$ & $\begin{array}{l}\text { Composite budget initiated in } \\
\text { Dangme East, Dangme West } \\
\text { and Akuapem North District. } \\
\text { Strategic Plan developed }\end{array}$ & $\begin{array}{l}\text { The integrated planning and } \\
\text { composite budgeting pilot is } \\
\text { implemented according to } \\
\text { schedule. In addition to the } 3 \\
\text { districts where the pilot is } \\
\text { currently being implemented, } \\
22 \text { more districts have been } \\
\text { tentatively selected ( } 2 \text { from } \\
\text { each region, but excluding the } \\
\text { newly created districts and the } \\
\text { districts that these were }\end{array}$ & Done \\
\hline
\end{tabular}




\begin{tabular}{|c|c|c|c|c|c|c|}
\hline Program Area & Objectives and Indicators & Target & $\begin{array}{l}\text { Indicator Level } \\
2002\end{array}$ & $\begin{array}{l}\text { Indicator Level } \\
2003\end{array}$ & $\begin{array}{l}\text { Indicator Level } \\
2004\end{array}$ & $\begin{array}{l}\text { Progress towards } \\
\text { Target }\end{array}$ \\
\hline & & & & & carved from.) & \\
\hline & $\begin{array}{l}\text { Operationalize the Local } \\
\text { Government Service act by } \\
\text { establishing its governing body } \\
\text { (Local Government Council and } \\
\text { Secretariat), by preparing } \\
\text { conditions and scheme of } \\
\text { service and by developing } \\
\text { guidelines and modalities for the } \\
\text { establishment of the } \\
\text { consolidated departments of the } \\
\text { Regional Coordination Councils } \\
\text { and District Assemblies. }\end{array}$ & $\begin{array}{l}\text { Letter of appointment of } \\
\text { Council Members } \\
\text { At least one formal } \\
\text { meeting of the Council } \\
\text { (Minutes) } \\
\text { Appointment of the Head } \\
\text { of the LGS, } \\
\text { organizational structure } \\
\text { prepared. } \\
\text { Budget line for the } \\
\text { Council's secretariat in } \\
\text { MLGRD's budget } \\
\text { Work Plan for } 2005 \\
\text { Draft document outlining } \\
\text { conditions and scheme of } \\
\text { service. } \\
\text { Availability of ToR for } \\
\text { the guidelines and } \\
\text { implementation } \\
\text { modalities. } \\
\text { Availability of timetable } \\
\text { for preparation guidelines } \\
\text { and implementation } \\
\text { modalities } \\
\text { Designated Coordinator } \\
\text { in place }\end{array}$ & & $\begin{array}{l}\text { Implementation Action Plan } \\
\text { under consideration (NDAP) } \\
\text { Presidential Advisory Cttee } \\
\text { established to advise on } \\
\text { National Decentralisation } \\
\text { Decentralisation Secretariat in } \\
\text { place }\end{array}$ & $\begin{array}{l}\text { In line with the requirements } \\
\text { of Clause } 5 \text { of the LGS-A656, } \\
\text { the governing body for the } \\
\text { Service, including its Head, } \\
\text { has been appointed. An } \\
\text { appropriate organizational / } \\
\text { functional structure for the } \\
\text { Council's Secretariat is under } \\
\text { preparation. } \\
\text { Preparation of the conditions } \\
\text { and scheme of service for the } \\
\text { LGS has been initiated } \\
\text { In line with the requirements } \\
\text { of clauses } 16-24 \text { of the LGS- } \\
\text { A656, preparations for the } \\
\text { establishment of consolidated } \\
\text { departments have been } \\
\text { initiated and are ongoing }\end{array}$ & \\
\hline $\begin{array}{l}\text { Improving } \\
\text { performance of } \\
\text { the public sector }\end{array}$ & $\begin{array}{l}\text { Implement refocused public } \\
\text { sector reform } \\
\text { Begin implementation of } \\
\text { priority areas of public sector } \\
\text { reform aimed at improving } \\
\text { service delivery capacity of the } \\
\text { civil and public service, }\end{array}$ & $\begin{array}{l}\text { Plan for implementation } \\
\text { of finalized Public Sector } \\
\text { Reform strategy produced } \\
\text { for the Civil Service } \\
\text { including an HR } \\
\text { framework as defined in } \\
\text { the strategy document }\end{array}$ & & & $\begin{array}{l}\text { Work commissioned for } \\
\text { project document to be } \\
\text { completed by end Q1, } 2005 \text {. } \\
\text { Current emphasis is on the } \\
\text { civil service rather than the } \\
\text { entire public service. }\end{array}$ & \\
\hline
\end{tabular}




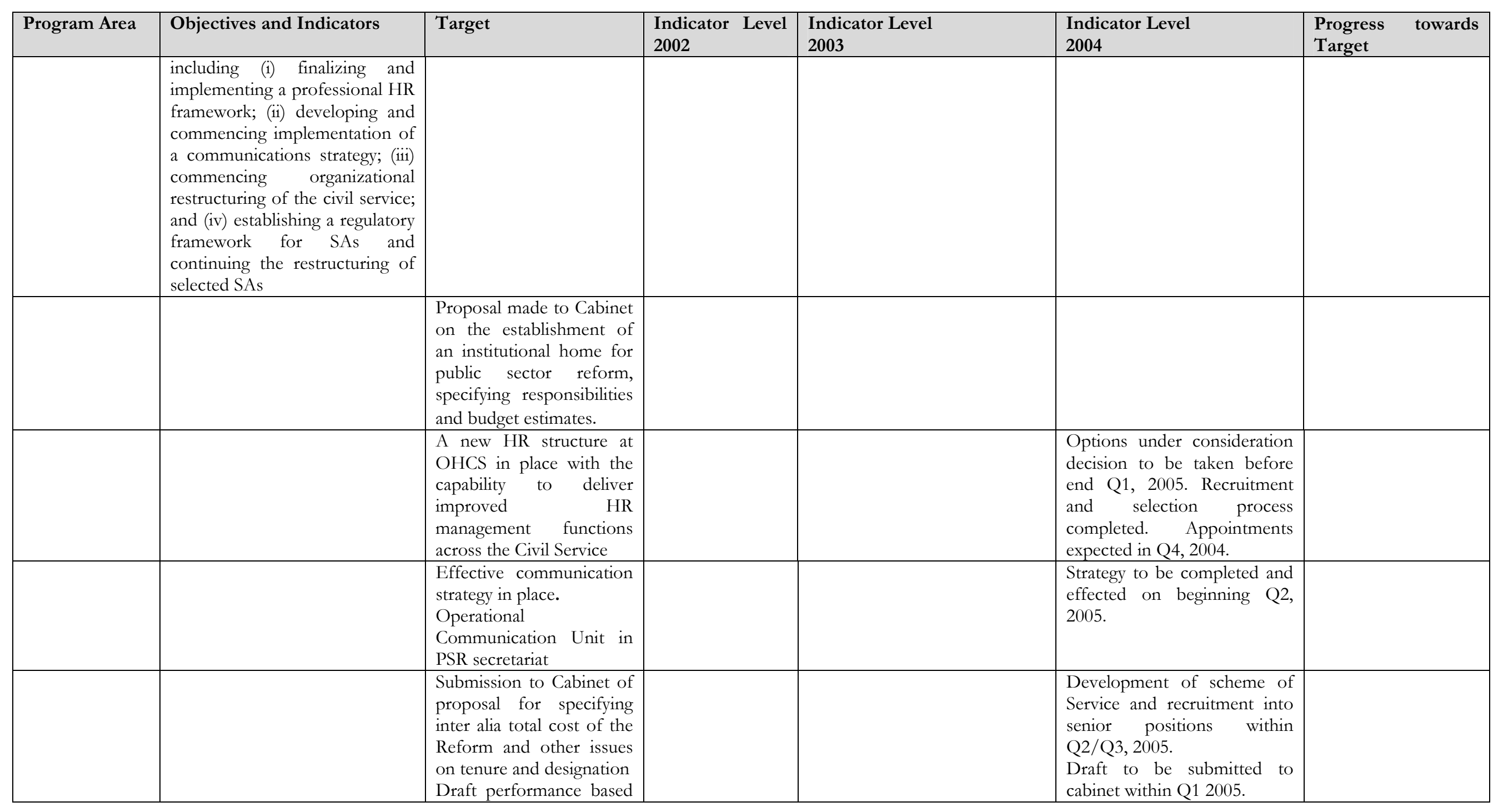




\begin{tabular}{|c|c|c|c|c|c|c|}
\hline Program Area & Objectives and Indicators & Target & $\begin{array}{l}\text { Indicator Level } \\
2002\end{array}$ & $\begin{array}{l}\text { Indicator Level } \\
2003\end{array}$ & $\begin{array}{l}\text { Indicator Level } \\
2004\end{array}$ & $\begin{array}{l}\text { Progress towards } \\
\text { Target }\end{array}$ \\
\hline & & 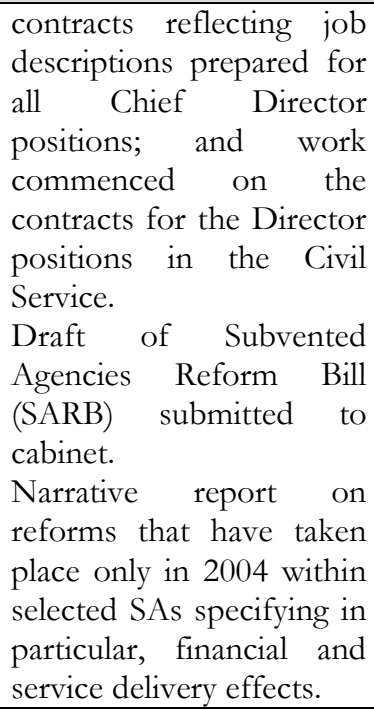 & & & & \\
\hline & $\begin{array}{l}\text { Strengthen budget execution } \\
\text { and reporting } \\
\text { Establish Internal Audit Agency } \\
\text { Secretariat and begin process of } \\
\text { staffing existing Internal Audit } \\
\text { positions in MDAs and } \\
\text { MMDAs }\end{array}$ & $\begin{array}{l}\text { The Director-General and } \\
\text { Unit Heads of the } \\
\text { Internal Audit Agency in } \\
\text { place. } \\
\text { Appointment process to } \\
\text { fill vacant existing internal } \\
\text { audit positions in MDAs } \\
\text { and MMDAs well } \\
\text { advanced. }\end{array}$ & & & $\begin{array}{l}\text { The process for the } \\
\text { appointment of Director- } \\
\text { General of the Internal Audit } \\
\text { Agency is in progress. } \\
\text { Advertisements have gone } \\
\text { out in daily newspapers } \\
\text { requesting applications for } \\
\text { various positions in the } \\
\text { Secretariat of the Agency. }\end{array}$ & \\
\hline & $\begin{array}{l}\text { Create and staff Internal Audit } \\
\text { Units in MDAs and MMDAs } \\
\text { currently without such Units }\end{array}$ & $\begin{array}{l}\text { Internal Audit Units } \\
\text { created and staffed in } \\
\text { MDAs and MMDAs } \\
\text { without Internal Audit } \\
\text { Units } \\
\text { (IAAB by Feb. } 2005 \text { to }\end{array}$ & & $\begin{array}{l}\text { Full compliment of staffing in } \\
\text { place by March } 312004\end{array}$ & $\begin{array}{l}\text { Under the Internal Audit } \\
\text { Agency Act, the current } \\
\text { Internal Auditors at the } \\
\text { various MDAs and MMDAs } \\
\text { shall be deemed to be internal } \\
\text { audit staff of various MDAs }\end{array}$ & \\
\hline
\end{tabular}




\begin{tabular}{|c|c|c|c|c|c|c|}
\hline Program Area & Objectives and Indicators & Target & $\begin{array}{l}\text { Indicator Level } \\
2002\end{array}$ & $\begin{array}{l}\text { Indicator Level } \\
2003\end{array}$ & $\begin{array}{l}\text { Indicator Level } \\
2004\end{array}$ & \begin{tabular}{|l|}
$\begin{array}{l}\text { Progress towards } \\
\text { Target }\end{array}$ \\
\end{tabular} \\
\hline & & $\begin{array}{l}\text { provide baseline data as at } \\
\text { April 2004, and } \\
\text { estimation of completion } \\
\text { by April, June and } \\
\text { December 2005.) }\end{array}$ & & & $\begin{array}{l}\text { and MMDAs, but are subject } \\
\text { to reassignment. } \\
\text { A list of MDAs and } \\
\text { MMDAs without } \\
\text { Internal Audit Units } \\
\text { would be completed with } \\
\text { the view to formally } \\
\text { instructing them to } \\
\text { establish and staff their } \\
\text { Internal Audit Units by } \\
\text { end February } 2005 \text {. } \\
\text { Meanwhile a general } \\
\text { circular requesting such } \\
\text { MDAs and MMDAs } \\
\text { without Internal Audit } \\
\text { Units to establish their } \\
\text { Units and submit returns } \\
\text { would have been issued }\end{array}$ & \\
\hline & $\begin{array}{l}\text { Fully operationalize Public } \\
\text { Procurement Institutions } \\
\text { MDAthin }\end{array}$ & $\begin{array}{l}\text { Chief Executive and Unit } \\
\text { Heads of the Public } \\
\text { Procurement Board in } \\
\text { place. } \\
\text { All Entity Tender Review } \\
\text { Boards in place and of the } \\
\text { Entity Tender } \\
\text { Committees, at least } 95 \% \\
\text { at the Ministerial level, } \\
\text { and } 50 \% \text { at the } \\
\text { Department and Agencies } \\
\text { level formed and } \\
\text { functional. }\end{array}$ & & $\begin{array}{l}\text { The Board is to be in place by } \\
\text { March } 2004 \text {. } \\
\text { Awareness creation on the Act } \\
\text { is currently on-going }\end{array}$ & $\begin{array}{l}\text { The Chief Executive of the } \\
\text { Public Procurement Board is } \\
\text { in the process of being } \\
\text { appointed. Advertisements } \\
\text { have gone out for the } \\
\text { appointment of Heads of } \\
\text { Divisions within the } \\
\text { Secretariat and the required } \\
\text { professional and secretarial } \\
\text { staff. } \\
\text { Tender Review Boards in } \\
\text { MDAs and MMDAs are in } \\
\text { the process of being } \\
\text { constituted. }\end{array}$ & \\
\hline
\end{tabular}




\begin{tabular}{|c|c|c|c|c|c|c|}
\hline Program Area & Objectives and Indicators & Target & $\begin{array}{l}\text { Indicator Level } \\
2002\end{array}$ & $\begin{array}{l}\text { Indicator Level } \\
2003\end{array}$ & $\begin{array}{l}\text { Indicator Level } \\
2004\end{array}$ & $\begin{array}{l}\text { Progress towards } \\
\text { Target }\end{array}$ \\
\hline & $\begin{array}{l}\text { Expand the Government's } \\
\text { computerized financial and } \\
\text { accounting system to cover } \\
\text { additional four (4) MDAs }\end{array}$ & $\begin{array}{l}\text { The Budget and Public } \\
\text { Expenditure Management } \\
\text { System (BPEMS) using } \\
\text { Oracle Financials will be } \\
\text { operational (all modules) } \\
\text { in four more MDA } \\
\text { Headquarters that is: } \\
\text { - Ministry of Interior - } \\
\text { headquarters } \\
\text { - Ministry of Works } \\
\text { and Housing - } \\
\text { headquarters } \\
\text { - Ministry of } \\
\text { Information - } \\
\text { headquarters } \\
\text { - Ministry of Local } \\
\text { Government and } \\
\text { Rural Development - } \\
\text { headquarters. }\end{array}$ & & & $\begin{array}{l}\text { Currently, set up of Oracle } \\
\text { Financials as a centralised } \\
\text { solution is } 100 \% \text { complete in } \\
\text { both test and production } \\
\text { instance for the following } \\
\text { MDAs' headquarters: } \\
\text { - Ministry of Finance } \\
\text { - Controller \& Accountant } \\
\text { - General } \\
\text { - Ministry of Health } \\
\text { Headquarters } \\
\text { - Ghana Health Service } \\
\text { Headquarters } \\
\text { - Ministry of Education, } \\
\text { Youth and Sports } \\
\text { Headquarters } \\
\text { - Ghana Education Service } \\
\text { Headquarters } \\
\text { - Ministry of Roads and } \\
\text { Transport Headquarters }\end{array}$ & \\
\hline & $\begin{array}{l}\text { Auditor-General to submit } 2003 \\
\text { audited accounts for the } \\
\text { Consolidated Fund and MDAs }\end{array}$ & $\begin{array}{l}2003 \text { Audit Reports on } \\
\text { Consolidated Fund and } \\
\text { on MDAs submitted to } \\
\text { Parliament. }\end{array}$ & & & $\begin{array}{l}\text { In respect of } 2003 \text { report on } \\
\text { MDAs, the Auditor-General } \\
\text { in November } 2004 \text { submitted } \\
\text { advance copies to MoFEP } \\
\text { and the Parliament while } \\
\text { printing of the report is in } \\
\text { progress. }\end{array}$ & \\
\hline & 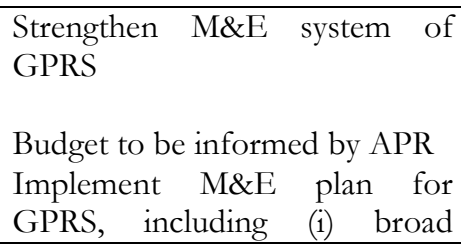 & $\begin{array}{l}2005 \text { Budget Statement } \\
\text { reflects the relevant } \\
\text { findings of the } 2003 \text { APR. } \\
\text { Implementation of M\&E } \\
\text { and Communications }\end{array}$ & $\begin{array}{ll}2002 & \text { APR } \\
\text { submitted } & \end{array}$ & $\begin{array}{l}2003 \text { APR under preparation } \\
4 \text { PSIAs completed } \\
\text { SEA Completed }\end{array}$ & $\begin{array}{l}\text { The preparation of the } 2005 \\
\text { budget involved the use of } \\
\text { the APR } 2003 \text {. } \\
\text { The technical Steering } \\
\text { Committee on the GPRS }\end{array}$ & \\
\hline
\end{tabular}




\begin{tabular}{|c|c|c|c|c|c|c|}
\hline Program Area & Objectives and Indicators & Target & $\begin{array}{l}\text { Indicator Level } \\
2002\end{array}$ & $\begin{array}{l}\text { Indicator Level } \\
2003\end{array}$ & $\begin{array}{l}\text { Indicator Level } \\
2004\end{array}$ & $\begin{array}{l}\text { Progress towards } \\
\text { Target }\end{array}$ \\
\hline & $\begin{array}{l}\text { dissemination and feedback on } \\
\text { GPRS APR, and (ii) carrying out } \\
\text { additional PSIAs in areas } \\
\text { selected through a consultative } \\
\text { process } \\
\text { Improve M\&E capacity by } \\
\text { increasing resources available } \\
\text { for M\&E and the } \\
\text { implementation of participatory } \\
\text { M\&E activities such as } \\
\text { expenditure tracking surveys } \\
\text { and Citizen report cards }\end{array}$ & 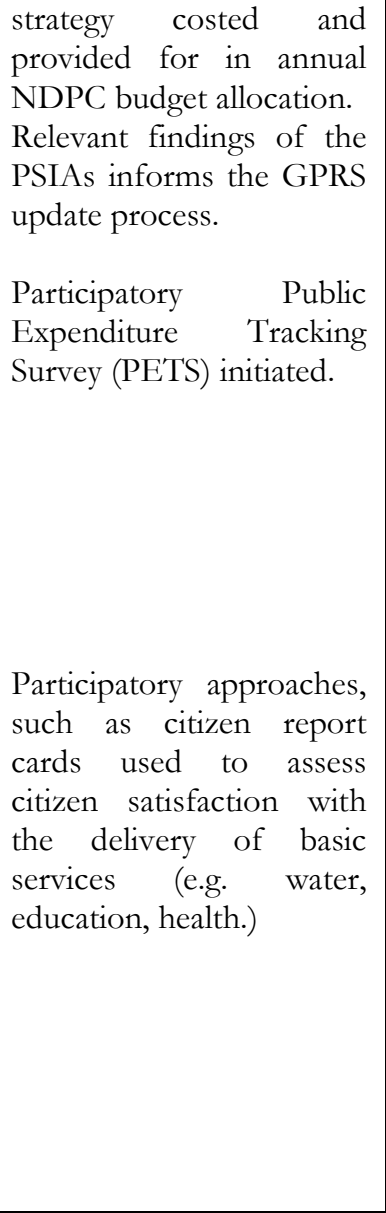 & & & $\begin{array}{l}\text { Communication Strategy } \\
\text { organised a Regional Trainer } \\
\text { of Trainers Workshop on the } \\
\text { GPRS. } \\
\text { Simplified versions of the } \\
\text { GPRS have been translated in } \\
\text { seven local languages and } \\
\text { disseminated. } \\
\text { The } 2003 \text { APR was discussed } \\
\text { extensively at the 2004 } \\
\text { National Economic Dialogue. } \\
\text { The Strategic Environmental } \\
\text { Assessment was discussed } \\
\text { extensively at a Ministerial } \\
\text { Conference in } 2004 \\
\text { Regional Poverty Monitoring } \\
\text { Groups have been formed in } \\
\text { the regions except the Eastern } \\
\text { Region } \\
\text { The Development Dialogue } \\
\text { Series continued in } 2004 \\
\text { PME on selected basic } \\
\text { services and impact of macro } \\
\text { economic reforms on } \\
\text { households livelihoods was } \\
\text { done in } 2004\end{array}$ & \\
\hline & $\begin{array}{lcc}\text { Final draft of } & \text { Freedom of } \\
\text { Information Bill presented } & \text { to } \\
\text { Cabinet } & & \\
\end{array}$ & & & Revision of draft in progress & Revision of draft in progress & \\
\hline
\end{tabular}




\begin{tabular}{|c|c|c|c|c|c|c|}
\hline Program Area & Objectives and Indicators & Target & $\begin{array}{l}\text { Indicator Level } \\
2002\end{array}$ & $\begin{array}{l}\text { Indicator Level } \\
2003\end{array}$ & $\begin{array}{l}\text { Indicator Level } \\
2004\end{array}$ & $\begin{array}{l}\text { Progress towards } \\
\text { Target }\end{array}$ \\
\hline & $\begin{array}{l}\text { Final draft of Whistle Blower } \\
\text { Bill presented to Cabinet }\end{array}$ & & & Revision of draft in progress & Revision of draft in progress & \\
\hline & $\begin{array}{l}\text { Diagnostic study on institutional } \\
\text { mandates of anti-corruption } \\
\text { agencies commissioned }\end{array}$ & & & $\begin{array}{l}\text { Draft Terms of Reference } \\
\text { prepared for focus group } \\
\text { discussion and review }\end{array}$ & & \\
\hline & $\begin{array}{l}\text { Electronic expenditure reporting } \\
\text { system installed in MoF, } \\
\text { CAGD, and at least two key } \\
\text { sector ministries }\end{array}$ & & & Installed in MoF and CAGD & $\begin{array}{l}\text { Installed also in the following } \\
\text { MDAs } \\
\text { - Ministry of Health; } \\
\text { - Ghana Health Service; } \\
\text { - Ministry of Interior } \\
\text { (Headquarters); } \\
\text { - Ministry of Education } \\
\text { Youth \& Sports; } \\
\text { - Ghana Education Service } \\
\text { (Headquarters); and } \\
\text { - Ministry of Roads \& } \\
\text { Transport Headquarters }\end{array}$ & \\
\hline
\end{tabular}




\section{CHAPTER EIGHT}

\section{THE VULNERABLE AND THE EXCLUDED}

\subsection{INTRODUCTION}

The government acknowledges that measures need to be instituted to mitigate the effects of shocks on sections of the population that are ordinarily by themselves, incapable of coping and preventing of incidence of certain types of shocks when they occur. Publicly funded social protection schemes that essentially involve providing support to the social groups that are most liable to shocks are therefore used to insulate the vulnerable and the excluded ${ }^{13}$.

\subsection{STATUS OF APR 2003 VULNERABLE AND EXCLUDED POLICY RECOMMENDATIONS}

Progress on the implementation of policy recommendations made in the 2003 APR is presented in Table 8.1 below

Table 8.1: Status of APR 2003 Vulnerable and Excluded Policy recommendations

\begin{tabular}{|c|c|}
\hline APR 2003 Policy Recommendation & Status in 2004 \\
\hline $\begin{array}{l}\text { There is a need to improve the logistics situation } \\
\text { and service conditions of staff of the Legal Aid } \\
\text { Board and the Department of Social Welfare. }\end{array}$ & $\begin{array}{l}\text { No logistical support was made available to these } \\
\text { institutions in the year under review. There are } \\
\text { plans to provide support in this fiscal year. }\end{array}$ \\
\hline $\begin{array}{l}\text { Children in 'difficult circumstances' are especially } \\
\text { vulnerable but there are no indicators to enable } \\
\text { effective tracking. Studies to determine and provide } \\
\text { baseline data on the extent of the problem will be } \\
\text { useful for measuring changes in future. }\end{array}$ & $\begin{array}{l}\text { A Social Protection Strategy is currently been } \\
\text { drafted for the Vulnerable and excluded. The } \\
\text { Department of Social Welfare conducted a survey } \\
\text { on Orphans and Vulnerable Children in } 11 \text { districts } \\
\text { with assistance from UNICEF. A Common } \\
\text { Country Assessment study on Vulnerability, } \\
\text { exclusion and Protection was conducted in } 2004 \text {. }\end{array}$ \\
\hline $\begin{array}{l}\text { An aspect of the provision of social assistance to } \\
\text { vulnerable and excluded groups which seems to } \\
\text { have been taken for granted is the mainstreaming of } \\
\text { assistance to such groups. The fact that these are } \\
\text { crosscutting issues calls for far greater collaboration } \\
\text { between agencies in the social sector as well as } \\
\text { economic sectors than is currently the case. }\end{array}$ & $\begin{array}{l}\text { The DSW has a microfinance scheme for Person's } \\
\text { with Disability. Many registered unemployed youth } \\
\text { acquired employable skills under the Skills Training } \\
\text { and Employment Placement Programme. } \\
\text { Some were also assisted with capital under the } \\
\text { Youth Development Fund. }\end{array}$ \\
\hline $\begin{array}{l}\text { It is important to continue to improve coordination } \\
\text { between the various interest groups working on the } \\
\text { anti-HIV/AIDS campaign, in order to ensure a } \\
\text { harmony of messages. GAC should assume a more } \\
\text { central role in coordinating the national response to } \\
\text { HIV/AIDS and in partner coordination seek ways } \\
\text { to pool resources. }\end{array}$ & GAC have taken some actions \\
\hline $\begin{array}{l}\text { The GAC should strive to find new ways of } \\
\text { monitoring and evaluating the activities of its } \\
\text { partners in the Campaign to avoid the dissipation of } \\
\text { scarce resource through fraudulent deals. }\end{array}$ & Offenders are currently being prosecuted. \\
\hline
\end{tabular}

${ }^{13}$ The vulnerable and the excluded in this context include among others women and children, persons with disability, HIV positive persons, the extreme poor and the destitute. 
Under the current GPRS, policies and programmes to support the vulnerable and excluded focus on a) promoting social justice, b) reducing the spread of HIV/AIDS c) and recognising the rights of persons with disability.

\section{Outcomes of Policy Interventions}

Making legal aid services available countrywide has expanded the opportunities for the poor to access free legal aid. Proof of this is found in the increased number of persons who have benefited from the services in 2004 over those of the previous year. Almost 6000 persons applied for legal aid services in 2004 as compared with 4500 in 2003 . The effect of increased citizen accessibility to free legal aid services is a reduction in the period of remand of persons for commission of minor offences but more importantly of innocent people whose rights are violated through being remanded for offences they may not have committed. Expeditious legal aid services which result in shorter remand periods reduce the possibility of rights violation.

Greater awareness has been created on the rights of disabled persons. Under its Skills Training and Employment Programme and the Youth Development Fund arrangement many persons with disability have received vocational training and post-training support to enable them become self employed. Some were placed in various jobs through the Public Employment Centre.

\subsection{PROGRESS ON POLICY IMPLEMENTATION}

\subsubsection{Policy Area: Disability}

Policy Objective: Improve the quality of life of the physically handicapped

Equip the Disabled youth with Employable Skills:

WHO global estimates show that there are about 2million Ghanaians living with disabilities, reliable national data on disability is scarce (CCA 2004). The available data is not disaggregated by age and gender, and children are often grouped with adults. Also the National Disability Policy document indicates that more females $(15.2 \%)$ live with disability than males (13.4\%). The DSW registers PWDs and provides services through the Community Based Rehabilitation Programme; however many PWDs still cannot access the services provided because of the high cost of these services and because of the non-PWD friendly nature of the services. As part of the Departments' mandate to Integrate Persons with Disability into mainstream society a number of programmes and activities were organised for PWDs in 2004. A total of 537 PWDs were provided with employable skills as against 653 in 2003. Also 85 PWDs were assisted to be self employed in 2004 showing a drop in number assisted in 2003 (1029), however, 70 PWDs were provided with inclusive education in 2004 an increase of about $60 \%$ over the number in 2003. Other programmes to integrate PWDs into mainstream society are shown in Section D in this report.

Provide Support Services for Street beggars and Girl Head Poters "kaya yei"

Fifty girl head porters (Kaya yei) were trained in various vocations and assisted to settle in their communities to practice their trade by the DSW. Also 2500 street children received formal education, employable skill training, counselling on hygiene and 
reproductive health from the Community Poverty Reduction Programme- Street Children Component. ${ }^{14}$

Though there are several destitutes in the country, the Department of Social Welfare assisted only 23 male and 5 female destitute in 2004 as against 24 males and 3 females in 2003.

Though there is a policy on health exemption for paupers one cannot assess it without the intervention of the Department of Social Welfare. A total of 1551 paupers were assisted with the payment of hospital bills and related expenses.

\section{Strengthen the work of the Department of Social Welfare and Community Development and capacity of Child Care Workers}

The department of Social Welfare is the focal agency that is responsible for the vulnerable and excluded groups. It has offices in all the 110 districts and works in three programme areas namely: justice administration, child's right promotion and protection and community care. The department is hampered by inadequate funding, low quality of staff and logistics. The government allocation to the department for 2002-2004 ranged from $\not 184$ million to 261 million and the releases of funds were greatly delayed, thus hampering efficiency of its field operation.

As part of the departments' efforts to equip staff to be able to discharge their duties to the vulnerable and disadvantaged, a number of capacity building programmes were organised for some members of staff in the year 2004. Subject areas included those on HIV/AIDS, Strategic Planning, Conflict Management, Monitoring and Evaluation, Orphaned Vulnerable Children, Policies on Social Protection, Human Trafficking, Child Labour and an Annual Review Workshop. Below are details of such workshop/seminars/courses at the regional level.

Table 8.2: The number of capacity building programmes organized per region

\begin{tabular}{|l|c|}
\hline REGION & $\begin{array}{l}\text { NO. OF WORKSHOPS/ } \\
\text { PROGRAMMES ORGANIZED }\end{array}$ \\
\hline Volta Region & 4 \\
\hline Eastern Region & 4 \\
\hline Western Region & 3 \\
\hline Central Region & 4 \\
\hline Ashanti Region & 5 \\
\hline Brong-Ahafo Region & 4 \\
\hline Northern Region & 5 \\
\hline Upper East Region & 4 \\
\hline Upper West Region & 3 \\
\hline Greater Accra Region & 4 \\
\hline Total & $\mathbf{4 0}$ \\
\hline
\end{tabular}

At the Head Office level, workshops were organized on policy issues, programme planning, monitoring and evaluation. In addition to this, a five (5) day Annual Review

\footnotetext{
${ }^{14}$ Apart from these two agencies several NGOs are also involved in the provision of support for street children e.g. the Red Cross and Catholic Action for Street Children. According to The Ghana Child Labour Survey(2003), there are about 33,000 street children in the country and 71\% of them are illiterate.
} 
Workshop took place involving sixty-eight (68) selected core staff of the Department at the Bunso Cocoa College.

Additionally, a total of thirty-four (34) members of staff are pursuing various programmes in tertiary institutions at Diploma, Degree and Masters Levels. These programmes are geared towards upgrading their professional skills.

\section{Policy Recommendations}

The department of social welfare needs to be well resourced to be able to perform its mandate. The Persons' with Disability Bill must be enacted by Parliament. Research and disaggregated data should be collected nationwide to identify the population with groups affected by disability, their needs and available opportunities to facilitate planning.

\subsubsection{Policy Area: Social Justice}

Policy Objective: Attainment of Social Justice and Equity and Respect for human Rights

Increase resources for the protection of the rights of women and Children

The Department of Social Welfare, which works with government and nongovernmental institutions to integrate the vulnerable and the disadvantaged groups into mainstream society. The table below gives a trend analysis of the categories of services provided by the DSW from 2002 to 2004.

Table 8.3: Comparative Welfare Services Provided to the Vulnerable \& Excluded by Year

\begin{tabular}{|c|c|c|c|}
\hline \multicolumn{2}{|c|}{ Outcomes (2002) } & $\begin{array}{l}\text { Outcomes } \\
\text { (2003) }\end{array}$ & $\begin{array}{l}\text { Outcomes } \\
\text { (2004) }\end{array}$ \\
\hline \multicolumn{4}{|l|}{ A. Child Welfare Services } \\
\hline Juvenile cases investigated & 513 & 537 & 620 \\
\hline Probation cases handled & 630 & 291 & 1082 \\
\hline Juveniles handled in industrial school & 61 & 127 & 80 \\
\hline Remand Cases handled & 291 & 247 & 390 \\
\hline Children adopted by relatives & 242 & 313 & 277 \\
\hline Orphans adopted & 53 & 41 & 252 \\
\hline Day Care Centres supervised & 2395 & 2876 & 701 \\
\hline Day Care Centres registered & 79 & 1272 & 367 \\
\hline Paternity cases disposed of & 733 & 480 & 398 \\
\hline Maintenance and custody cases disposed of & 8493 & 9890 & 7109 \\
\hline Families reconciled and strengthened & 2649 & 743 & 3149 \\
\hline Male un-adoptable children cared for & 169 & 166 & \multirow{2}{*}{$\begin{array}{l}258 \text { (total for } \\
\text { both sexes) }\end{array}$} \\
\hline Female un-adoptable children cared for & 108 & 92 & \\
\hline Family tribunal cases handled & 5956 & 4839 & 2861 \\
\hline International Social Service cases handled & & 49 & 64 \\
\hline \multicolumn{4}{|l|}{ B. Vocational Training for the Youth } \\
\hline Boys provided with vocational training & 431 & 548 & 385 \\
\hline Girls provided with vocational training & 434 & 549 & 447 \\
\hline Street Children rehabilitated & 413 & 466 & 357 \\
\hline \multicolumn{4}{|c|}{ C. Integrating disadvantaged adults into mainstream society } \\
\hline Prisoners provided with welfare services & 2072 & 2585 & 1343 \\
\hline $\begin{array}{l}\text { Paupers assisted with payment of hospital bills and related } \\
\text { expenses }\end{array}$ & $\begin{array}{lr}\text { Males } & 937 \\
\text { Females } & 842 \\
\end{array}$ & $\begin{array}{lr}\text { Males } & 357 \\
\text { Females } & 175 \\
\end{array}$ & $\begin{array}{lr}\text { Males } & 732 \\
\text { Females } & 819 \\
\end{array}$ \\
\hline Destitutes catered for & $\begin{array}{lr}\text { Males } & 23 \\
\text { Females } & 3 \\
\end{array}$ & $\begin{array}{cc}\text { Males } 24 \\
\text { Females } 3 \\
\end{array}$ & $\begin{array}{l}\text { Male } 23 \\
\text { Female } 5\end{array}$ \\
\hline
\end{tabular}




\begin{tabular}{|l|c|c|c|}
\hline \multicolumn{1}{|l|}{ Women's groups assisted through Technology Capitalization } & 48 & \multicolumn{2}{l|}{} \\
\hline D. Integrating Persons With Disability (PWDs) into mainstream society & 593 & 653 & 537 \\
\hline PWDs provided with employable skills & 80 & 102 & 85 \\
\hline Trained PWDs assisted to be self-employed & 104 & 69 & 3760 \\
\hline PWDs assisted in communities & 63 & 19 & 70 \\
\hline PWDs provided with inclusive education & 55 & 27 & 40 \\
\hline Unit Committees members sensitised & & & 12 \\
\hline Running of Rehabilitation Centres & & 994 & 1233 \\
\hline Number of identified and registered PWDs & & & 14 \\
\hline $\begin{array}{l}\text { Number of trained visually impaired assisted with c3.8million } \\
\text { as start up capital by Catholic Relief Services \& Action Aid }\end{array}$ & & 11 & 210 \\
\hline Number of PWDs provided with wheel chairs & & 3060 & 3760 \\
\hline Number of PWDs assisted in various ways & & 425 & 110 \\
\hline Number of districts sensitized on disability & & & 327 \\
\hline $\begin{array}{l}\text { Number of PWDs trained in institutions (Rehabilitation } \\
\text { Centres) }\end{array}$ & & & \\
\hline E. HIV/AIDS & & & 52 \\
\hline PLWHAs received care and support & & \\
\hline $\begin{array}{l}\text { NGOs working in partnership with DSW in HIV/AIDS } \\
\text { programme }\end{array}$ & & & 1500 \\
\hline Parent sensitized on HIV/AIDS & & & \\
\hline
\end{tabular}

Source: Department of Social Welfare

Some districts have set a few gender specific annual targets and indicators, but not all. Some districts provide also good examples how existing funds can be used to promote women's empowerment and to provide credits to women, and to promote girls' education. In some cases a certain percentage of the DACF is earmarked to improve child-girl-education. Various NGOs and CSOs are also actively involved in activities to empower women and to promote girls' education.

Good understanding of and commitment to gender related issues are key to ensure gender specific analysis, planning, budgeting and monitoring of specific targets. There is a great variety among districts to what extent this is happening, but overall it can be said that there is still a long way to go to ensure that gender equity can be reached. District staff need to receive more support, guidance and incentives for promoting gender equity.

Good progress has been made in those districts where sustained and continuous efforts and support have been in place to promote gender equality. An example is the DISCAP Strategy in 18 districts in Upper Western, Upper Eastern and Northern Regions, which aims at increasing institutional district capacities to achieve gender equality as part of GOG's objective to integrate gender into its local government structures.

It supports increased participation of women and mainstreaming gender equality issues in policies, programming and structures of local government institutions. It started in 2001 and systematically made an assessment, gender profiles and strategies, including literature kits with good practices, manuals and guidelines. In 2004 a training manual was developed and the project was expanded to 8 more districts of the Northern region where it did not work previously. The establishment of Gender Desk Officers at management level of authority (part of DPCU) has proven to be a positive step towards equitable governance. The core group of trainers of the program has male and female members, and there are also some male Gender Desk Officers.

There are various levels of maturity of the DISCAP strategy in the different districts and the extent to what gender is perceived as a shared commitment and integration in development plans. DISCAP has also resulted in more networking and targeting funds for women, and increased collaboration with NGO's, NCDW and MDAs in gender programming and awareness raising of negative social-cultural practices. Through effective lobbying one Gender Desk Officer managed to get seven more females in the District Assembly. Women have become more involved in development programs and their capacity is being built in water supply systems and in 
environmental health as the women previously had less access to training opportunities than the men. There is also more focus to changing behaviour of various target groups in development programs, from a gender perspective.

Source: DISCAP Progress Report 2004

\section{Empowerment of Women}

Ensuring Gender equity is explicitly mentioned in the GPRS as one of its goals as well as an important cross cutting issue. The GPRS M\&E Plan also highlights the importance of using gender dis-aggregated data to facilitate the monitoring of the objective of gender equity.

Gender equality and women's empowerment is also the third of the Millennium Development Goals. It is therefore explicitly valued as an end in itself and not just as an instrument for achieving other goals.

The GPRS emphasises that economic growth does not automatically benefit all groups equally, in particular the poor and women. In the medium term priorities, some specific objectives are mentioned:

* Reduction of gender disparities in education;

* Enhancement of women's access to and control of productive resources;

* Attainment of social justice and equity and respect for human rights.

\section{Activities/achievements}

The government launched in 2004 Ghana's National Gender and Children Policy, which states as goal: "to mainstream gender concerns in the national development process in order to improve the social, legal/civic, political, economic, and cultural conditions of the people of Ghana, particularly women and children", and one of its objectives is "to redress imbalances which arise from existing gender inequalities".

The National Policy highlights the importance to contribute to the development of Ghana by achieving equal status for women and to ensure women responsive development planning at all levels.

One of the government's strategies is to support Gender Desk Officers (GDO) in the various MDAs and in District Assemblies. In 2004 MOWAC organised GDOworkshops at national level, on their roles, strategic planning, lobbying/advocacy, strategic partnership etc, but more follow up and support is required. GDO's at district level have also proven to be effective in mainstreaming gender, if given the guidance, tools and technical support to fulfil their roles. ${ }^{15}$

In 2004 the National Economic Dialogue (NED) reviewed the progress of the GPRS as well as the need for modifications, and concrete policies and measures on gender equality were explicitly mentioned. The Women's Manifesto for Ghana was produced in 2004 by a wide variety of groups ${ }^{16}$, which demands a revision of the GPRS in view of gender inequality and the needs of the poor, in particular poor women. The Common Country

\footnotetext{
${ }^{15}$ See paragraph 8.3 .3

${ }^{16}$ Based on a broad range of consultations (women's groups, NGO's/CSO's, DA's, media, politicians, MDAs and Parliamentarians)
} 
Assessment on Vulnerable groups and Protection issues (CCA) was carried out in 2004, recommending gender equity and equality continue to be key principles of the GPRS, including gender analysis/planning/ budgeting approaches. The PSIA on Vulnerability/Exclusion once again recommends that policies and actions need to be reoriented to serve the objective of elimination of gender equalities, which will also enhance gains of other interventions aimed at poverty reduction. The SEA identifies clear links between poverty and gender inequalities as well, and has incorporated gender equality in its tools. So it is positive to note that the process to update the GPRS started in 2004 with a clear need and common agenda of various actors/sectors to mainstream gender.

A major effort was made in 2004 to review progress made so far during the last decade: the national Progress Report on Gender and Beijing plus 10 (incl. achievements and objectives for the way forward, to be presented by GoG in 2005 at the International Conference on Beijing plus 10). The government disseminated the Report on Population, Poverty and Development, with recommendations which complement the above mentioned Policies, Reports, Fora and Assessments. It can confidently be said that in 2004 a clear framework has been defined for setting objectives and addressing the challenges on gender, both in the GPRS and other policies.

The Ministry of Women and Children Affairs established the Women's Development Fund in 2001 to economically empower women. Seed money of $\$ 3$ million dollars was allocated to the fund. An amount of $₫ 35$ billion cedis has been disbursed to over 80,000 women farmer in the country. Also $\notin 3.6$ billion cedis has been used to purchase 208 cassava processing machines, 25 groundnut oil extraction and 25 shea butter processing machines for distribution to 258 women groups In addition an amount of $\phi 5 b$ billion cedis was disbursed to the women processors, each of them received $\$ 500,000$ as a working capital. A micro credit totaling $\notin 8.5$ billion has also been disbursed to 11,500 women in the coastal communities.

About 30,000 food vendors also received $₫ 25$ billion to support their trading. It has also supported 2600 women in Kokrobite, Ekumfi, Senya and Ada communities with $\notin 1.3$ billion cedis.

A total of $₫ 4.5$ billion is being processed for trained and needy women artisans under the WDF. In all about 5000 women will be provided with a sewing machine and a working capital of $₫ 500,000$ per beneficiary.

\section{Policy Recommendations}

District development plans need to incorporate analysis and social-cultural issues, which affect women's empowerment and gender equality.

Guidelines for the use of the DACF should be reviewed by MLGRD and a minimum percentage should be defined to be used for women's and girls' empowerment activities. An incentive system should be incorporated by MLGRD for those Districts who use resources (DACF, HIPC, Poverty Alleviation Fund, DP's and NGO's) to achieve gender equity in school enrolment, as this one key GPRS and MDG objective. 
The various HIPC and DACF funds should be monitored closely to ensure that women benefit and that these programs support the objective of gender equality and women's empowerment.

Gender Desk Officers need to be promoted and supported in all districts (incl. development of gender promotion skills, analysis, and monitoring for GDO's and other district staff), and good practices /experiences to promote gender equality should be shared with GDO's by MLGRD and MOWAC.

Wide dissemination of the National Gender and Children Policy is required, and MOFEP and MDAs should establish benchmarks on relative positions of women, men and children, identify priority areas and allocate resources accordingly.

MOWAC should commission a Beneficiary Impact Assessment Study, which should point the way forward. ${ }^{17}$ Various programs supporting MOWAC, MDAs and GDOs on gender should be harmonized, to ensure synergy effect, and to ensure that they all have the necessary tools, budget and authority to achieve gender equality and women's empowerment.

In the updated GPRS, and in formulating sector specific policies and action plans/budgets, explicit integration should be ensured of: a comprehensive analysis of gender inequalities, their causes and effects; strategic interventions needed to address these; costing of the implications of these interventions, including required expertise and capacity building efforts; and a gender specific ME framework to track progress and promote accountability with gender specific targets, indicators and guidelines on gender dis-aggregated data. Break downs of various levels of expenditures should be promoted, including expenditures targeted at women, expenditures intended to promote gender equality in the public sector, and the gender impact of mainstream budget expenditure.

Gender specific objectives and budgeting in the updated GPRS, should form the basis for gender specific targets for MDBS, PRSC, and other GPRS programs.

\section{Adequate security for the protection of the Vulnerable and Excluded}

The provision of adequate security for protection of the vulnerable and excluded is one of the core GPRS indicators and institutions such as the Ghana Police Service and WAJU. The Women and Juvenile Unit (WAJU) of the Ghana Police Service was set up to promote public support for the vulnerable groups such as women and children and ensure they are protected against all forms of violence and abuse.

Table 8.4: Statistics of cases reported to Women and Juvenile Unit (WAJU) Ghana Police Service from January 1999 to December 2004

\begin{tabular}{|c|c|c|c|c|c|c|c|}
\hline \multirow[t]{2}{*}{ Type of Case } & \multicolumn{6}{|c|}{ Year } & \multirow[b]{2}{*}{ Total } \\
\hline & 1999 & 2000 & 2001 & 2002 & 2003 & 2004 & \\
\hline Rape & 23 & 34 & 64 & 184 & 150 & 181 & 636 \\
\hline Defilement & 154 & 181 & 228 & 820 & 755 & 734 & 2872 \\
\hline Assault & 95 & 86 & 279 & 1861 & 2157 & 2059 & 6537 \\
\hline Threatening & 21 & 16 & 63 & 772 & 588 & 435 & 1895 \\
\hline Causing harm & 4 & 6 & 7 & 65 & 46 & 42 & 170 \\
\hline Causing damage & 6 & 3 & 7 & 73 & 49 & 70 & 208 \\
\hline Indecent assault & 11 & 17 & 29 & 104 & 90 & 74 & 325 \\
\hline
\end{tabular}

\footnotetext{
${ }^{17}$ See Beijing plus 10 Report, 2004, page 10
} 


\begin{tabular}{|c|c|c|c|c|c|c|c|}
\hline Incest & 5 & 6 & 5 & 20 & 17 & 15 & 68 \\
\hline Offensive conduct & 4 & 1 & 2 & 226 & 360 & 325 & 918 \\
\hline Unnatural carnal knowledge & 3 & 2 & 0 & 2 & 3 & 14 & 24 \\
\hline $\begin{array}{l}\text { Failing to supply necessities of } \\
\text { health and life }\end{array}$ & 0 & 7 & 17 & 164 & 102 & 67 & 357 \\
\hline Abduction & 3 & 5 & 10 & 147 & 169 & 190 & 524 \\
\hline Child stealing & 1 & 3 & 1 & 17 & 16 & 19 & 57 \\
\hline Stealing & 20 & 7 & 12 & 196 & 174 & 200 & 609 \\
\hline Exposing child to harm & 1 & 0 & 4 & 72 & 61 & 63 & 201 \\
\hline Criminal Abortion & 1 & 1 & 3 & 17 & 23 & 33 & 78 \\
\hline Fraud & 6 & 5 & 3 & 1 & 0 & 0 & 15 \\
\hline Attempted defilement & 0 & 0 & 1 & 3 & 2 & 0 & 6 \\
\hline Attempted rape & 1 & 2 & 3 & 23 & 32 & 16 & 77 \\
\hline Attempted abortion & 0 & 1 & 0 & 19 & 15 & 20 & 55 \\
\hline Non child maintenance $^{18}$ & 523 & 1383 & 1047 & 3066 & 5947 & 7421 & 19387 \\
\hline Bigamy & 0 & 0 & 0 & 0 & 3 & 4 & 7 \\
\hline Total & 882 & 1766 & 1785 & 7852 & 10759 & 11982 & 35026 \\
\hline
\end{tabular}

Source: WAJU Headquarters Records, Accra January 2005.

The statistics on crime records from WAJU for over the years shows that non-child maintenance forms more than half the total number of cases they receive every year. The impacts of child maintenance laws have been limited because enforcement is aimed at defaulters in the formal sector who are salaried workers while the bulk of the cases relate to workers in the informal sector. Failure of maintenance claims result in children being deprived of education, health, food and adequate care. The root causes of maintenance claims include casual or informal unions between parents, irresponsible fatherhood, polygyny, paternity disputes, problems related to property rights of women upon dissolution of marriages, unemployment and poverty. This is followed by assault and defilement. However, cases on assault, causing harm, threatening, indecent assault, incest and exposing child to harm have since 2002 been gradually reducing. These trends can be attributed to the fact that WAJU has intensified its public education programme and people are now aware of the criminal consequences of their actions.

\section{Policy Recommendations}

The challenge is, for Women and Juvenile Unit of the Police Service and the Department of Social welfare to be well resourced to be able to handle the increasing number of cases they are handling.

The cause of the increasing cases of non child maintenance needs to be investigated further. Also public education on child maintenance regulation is necessary to enlighten people about their rights to maintenance and where to obtain assistance. The children's Act should be reviewed to ensure parents working in the informal sector maintain their children.

\section{Utilization of legal Service}

Compared to 2003, there is a remarkable improvement in the utilization rate of legal aid services as a result of extension of services to every part of the country. Almost 6000 persons applied for legal aid services and 5090 of these were provided with the services in 2004 as compared with 4500 of the previous year. About 60 per cent of all cases

\footnotetext{
18 The staff of Department of Social Welfare attached to WAJU offices handle issues on non-child maintenance
} 
before the Legal Aid Board were successfully disposed of. Also, unlike the previous years, free legal aid can now be received nationwide.

\section{Policy Recommendations}

The Legal Aid Board needs to be adequately resourced to be able to deliver their service of defending to a wider number of people who need their services.

A policy should be developed to provide tax rebate for lawyers who provide legal aid services to the poor. Secondly members of the Ghana Bar Association should be encouraged to extend legal aid services to the poor for a proportion of the fees.

\section{Policy Area: HIV/AIDS}

Policy Objective: Prevent the spread of HIV/AIDS and improve the quality of life
of people living with HIV/AIDS and Orphans of AIDS

The median HIV seroprevalence of 3.6 per cent of 2003 was reduced to 3.1 percent in 2004. Though this may gives an indication that the interventions are succeeding in halting the scourge from assuming epidemic proportions, it however does not necessarily represent an overall decline of HIV infection in the country although it may be the earliest sign of an epidemic slow down. Although most sites recorded either a decline or a lower level of increase compared to 2003 , the mean prevalence of all sites in the last 5 years (2000 to 2004$)$ is $3.5 \%$.

There are wide variations in regional, rural and urban, and age group prevalence rates. The mean regional HIV prevalence ranged from 1.7\% in the Upper West region to 6.5\% in the Eastern Region. HIV prevalence for the rural and urban sentinel sites were median $(2.8 \%$ and $3.6 \%)$ and mean $(3.4 \%$ and $3.7 \%)$ respectively. The $25-29$ age group for instance, recorded the highest mean HIV prevalence of $4.5 \%$. The mean prevalence was $2.0 \%$ in the $15-19$ year age group and $2.5 \%$ in the $15-24$ year age group. Also significant shifts have been recorded among the different age groups, which indicate an upward and downward trend in the young adult group.

With regard to HIV/AIDS control, access of AIDS patients to antiretroviral therapy (ART) increased with the establishment of 4 facilities by mid-year as against the target of 6 by the end of 2004. As a result, 1176 patients had been put on ART by mid-year as against the targeted 2,000 for the full year. Twenty-Nine Voluntary Council and Testing Centres (VCT) as against the targeted 66 VCT centres were established by mid-year; and 302 mother-baby pairs were treated with Niverapine by mid-year as against the target of 6,000 mother-baby pairs for 2004.

NGOs have been approved for funding under the $4^{\text {th }}$ call. The criteria for selection included those with interventions being carried out in high risk areas with prevalence higher than 5\%; (Adabraka, Wenchi, Mampong-Ashanti, Eikwe, Fanteakwa, Cape-Coast, Agomanya and Kumasi) interventions targeting vulnerable groups such as Orphans and 
Vulnerable Children, Persons living with and / or affected by HIV / AIDS; interventions targeting high risk groups such as commercial sex workers, miners, truck drivers.

Out of the 149 beneficiaries, 34 NGOs were selected to work in high prevalence areas and / or with vulnerable / high risk groups; 24 NGOs are working with commercial sex workers, 4 are working with truck drivers and 6 with migrant workers e.g. miners. The remaining 115 NGOs are working with PLWHAs and are into care and support.

The DSW also sensitised 1500 parents on HIV/AIDS and provided support to 52 PLWHAs in 2004 and is working in partnership with 500 NGOs in the area of $\mathrm{HIV} / \mathrm{AIDS}$.

\section{Policy Recommendation}

Expanding access to ART for PLWHAs remains a major challenge for the country and therefore there is the need to expand the number of sites and beneficiaries. Also more VCT Centres should be opened. The Ghana AIDS Commission should put in place an effective monitoring system to monitor the activities of NGOs who receive funding for HIV/AIDS activities.

\section{Prepare a social protection strategy}

The NDPC have been working jointly with the Sector Ministry on the development of a social Protection Strategy for Ghana. This strategy is expected to provide the critical mass of input required for the update and revision of the technical content of the section on Vulnerability, an Exclusion thematic area of the revised agenda, GPRS 2. A technical committee to provide technical direction has been constituted and is operational. Among the outputs has been the development of a Conceptual Framework and Action Plan for Ghana. There are ongoing consultations with primary actors/stakeholders on the technical findings and recommendations. The Strategy is expected to be ready for submission to Cabinet on May 31, 2005.

A national social protection policy which enhances the capacity of individuals, households and communities to handle risks that confront them has become an imperative. The current effort at preparing a national social protection strategy, will need to be intensified. 
Table 8.4: Summary of Status of Priority Indicators for Vulnerable and Excluded

\begin{tabular}{|c|c|c|c|c|c|c|}
\hline $\begin{array}{l}\text { Program } \\
\text { Area }\end{array}$ & Objectives & Target & $\begin{array}{l}\text { Indicator Level } \\
2002\end{array}$ & $\begin{array}{l}\text { Indicator } \\
\text { Level } 2003\end{array}$ & $\begin{array}{l}\text { Indicator } \\
\text { Level } 2004\end{array}$ & $\begin{array}{l}\text { Progress towards } \\
\text { Target }\end{array}$ \\
\hline \multicolumn{7}{|l|}{ MTP } \\
\hline & $\begin{array}{l}\text { Increased resources for the protection } \\
\text { of the rights of women and children }\end{array}$ & & $\begin{array}{l}\text { MOWCA received } \\
\not \subset 6.709 \text { billion in } \\
2002\end{array}$ & $\begin{array}{l}\text { MOWCA received } £ 9.669 \text { billion in } \\
2003\end{array}$ & $\begin{array}{l}\text { MOWCA received } ф 20,563 \\
\text { million in } 2004\end{array}$ & On track \\
\hline & Incidence of poverty & $32 \%$ & $39 \%-(2000)$ & $\mathrm{N} / \mathrm{A}$ & $\mathrm{N} / \mathrm{A}$ & \\
\hline & Incidence of extreme poverty & $21 \%$ & $27 \%$ & $\mathrm{~N} / \mathrm{A}$ & $\mathrm{N} / \mathrm{A}$ & \\
\hline & $\begin{array}{l}\text { Accessibility of services (disaggregated } \\
\text { to services, region, districts) }\end{array}$ & & & $\begin{array}{l}\text { Some data is available from the } 2003 \\
\text { CWIQ, but not enough to establish } \\
\text { levels }\end{array}$ & same & \\
\hline & $\begin{array}{l}\text { Access of extreme poor to services } \\
\text { (disaggregated to services, region, } \\
\text { districts }\end{array}$ & & & $\begin{array}{l}\text { Some data is available from the } 2003 \\
\text { CWIQ, but not enough to establish } \\
\text { levels }\end{array}$ & same & \\
\hline & $\begin{array}{l}\text { Appropriate indicators developed to } \\
\text { monitor change in well being of } \\
\text { vulnerable and excluded, across the } \\
\text { entire GPRS }\end{array}$ & & & $\begin{array}{l}\text { PSIA currently on going and } \\
\text { indicators are being developed }\end{array}$ & $\begin{array}{l}\text { A social protection strategy } \\
\text { policy is currently being } \\
\text { developed for the vulnerable } \\
\text { and excluded }\end{array}$ & On track \\
\hline & Utilisation of Legal Aid Services & & 4225 & 4500 & $\begin{array}{l}5590 \text { applied for legal Aid } \\
\text { services and } 5090 \text { received legal } \\
\text { aid services. Legal Aid Services } \\
\text { can now be received nation } \\
\text { wide }\end{array}$ & $\begin{array}{l}\text { Utilisation by poor } \\
\text { increasing but not } \\
\text { adequate }\end{array}$ \\
\hline & NGO funding for Legal Aid & & & $\begin{array}{l}\text { All Legal Aid offices in the country } \\
\text { are being computerized and net- } \\
\text { worked with assistance from } \\
\text { USAID }\end{array}$ & & \\
\hline & $\begin{array}{l}\text { Population with information, } \\
\text { counselling programmes undertaken }\end{array}$ & & & $98 \%$ & & On track \\
\hline & Provide support for PLWHIV/AIDS & & & 4 sentinel sites providing ART & & \\
\hline & $\begin{array}{l}\text { Improve the quality of life of the } \\
\text { physically handicapped }\end{array}$ & & & $\begin{array}{l}\text { Disability Bill developed and being } \\
\text { discussed }\end{array}$ & $\begin{array}{l}\text { The CRPR-SC is supporting } \\
\text { the Tamale Resource Centre } \\
\text { for PWDs to mainstream } 45 \\
\text { guides of PWD into formal }\end{array}$ & \\
\hline
\end{tabular}




\begin{tabular}{|c|c|c|c|c|c|c|}
\hline \multirow[t]{3}{*}{\begin{tabular}{|l|} 
Program \\
Area
\end{tabular}} & Objectives & Target & $\begin{array}{l}\text { Indicator Level } \\
2002\end{array}$ & $\begin{array}{l}\text { Indicator } \\
\text { Level } 2003\end{array}$ & $\begin{array}{l}\text { Indicator } \\
\text { Level } 2004\end{array}$ & $\begin{array}{l}\text { Progress towards } \\
\text { Target }\end{array}$ \\
\hline & & & & & education. & \\
\hline & $\begin{array}{l}\text { Provide care and support for street } \\
\text { beggars and kaya yei }\end{array}$ & & $\begin{array}{l}\text { Training in skills } \\
\text { provided }\end{array}$ & $\begin{array}{l}\text { Training in Vocational skills has } \\
\text { been provided to street beggars and } \\
\text { head potters }\end{array}$ & $\begin{array}{l}50 \text { Kaya yei were trained in } \\
\text { various vocations and have } \\
\text { settled in their communities to } \\
\text { practice their trade by the } \\
\text { DSW. } \\
\text { Also } 2500 \text { street children } \\
\text { received formal education, } \\
\text { employable skill training, } \\
\text { counseling on hygiene and } \\
\text { reproductive health from the } \\
\text { CPRP-SC. }\end{array}$ & \\
\hline & HIV AIDS Prevalence & & $3.8 \%$ & $3.4 \%$ & 3.1 & \\
\hline & $\begin{array}{l}\text { Drug Based treatment available for } \\
\text { people with AIDS }\end{array}$ & & & $\begin{array}{l}4 \text { Sentinel Sites are providing ART } \\
\text { for PLWHA and } 19 \text { sentinel site are } \\
\text { implementing a programme for the } \\
\text { prevention of mother to child } \\
\text { transmission }\end{array}$ & $\begin{array}{l}4 \text { facilities were established by } \\
\text { mid-year as against the target of } \\
6 \text { by the end of } 2004 \text { to provide } \\
\text { antiretroviral therapy (ART) to } \\
\text { AIDS patients. } \\
1176 \text { patients had been put on } \\
\text { ART by mid-year as against the } \\
\text { targeted } 2,000 \text { for the full year. } \\
29 \text { Voluntary Council and } \\
\text { Testing Centres (VCT) as } \\
\text { against the targeted } 66 \text { VCT } \\
\text { centres were established by } \\
\text { mid-year; } \\
302 \text { mother-baby pairs were } \\
\text { treated with Niverapine by } \\
\text { mid-year as against the target of } \\
6,000 \text { mother-baby pairs for }\end{array}$ & \\
\hline
\end{tabular}




\begin{tabular}{|c|c|c|c|c|c|c|}
\hline $\begin{array}{l}\text { Program } \\
\text { Area }\end{array}$ & Objectives & Target & $\begin{array}{l}\text { Indicator Level } \\
2002\end{array}$ & $\begin{array}{l}\text { Indicator } \\
\text { Level } 2003\end{array}$ & $\begin{array}{l}\text { Indicator } \\
\text { Level } 2004\end{array}$ & $\begin{array}{l}\text { Progress towards } \\
\text { Target }\end{array}$ \\
\hline & & & & & 2004 & \\
\hline \multicolumn{7}{|c|}{ MDBS 2005/ PRSC 3} \\
\hline & $\begin{array}{l}\text { Reduce the spread of the HIV/AIDS } \\
\text { epidemic } \\
\text { Accelerate implementation of } \\
\text { interventions for high risk groups and } \\
\text { areas with high prevalence taking into } \\
\text { consideration recommendations of the } \\
\text { joint review }\end{array}$ & $\begin{array}{l}\text { Prevalence of } \\
\text { HIV among } \\
\text { pregnant } \\
\text { women } \\
\text { retained below } \\
5 \% \text { in } 2005 \text { (the } \\
\text { current } \\
\text { prevalence of } \\
2003 \text { is } 3.6 \% \text {.) }\end{array}$ & & $\begin{array}{l}\text { Joint Review scheduled is between } \\
1^{\text {st }} \text { March } 2004 \& 9^{\text {th }} \text { April } 2004 \text {. A } \\
\text { budget of } \$ 218,00 \text { had been set } \\
\text { aside for it with funding form donor } \\
\text { agencies like DFID JICA, The Royal } \\
\text { Danish Embassy, UNAIDS, } \\
\text { USAID, UNFPA }\end{array}$ & $\begin{array}{l}149 \text { NGOs have been } \\
\text { approved for funding under the } \\
4^{\text {th }} \text { call. The criteria for } \\
\text { selection included those with } \\
\text { interventions being carried out } \\
\text { in high risk areas with } \\
\text { prevalence higher than } 5 \% \text {; and } \\
\text { support. }\end{array}$ & \\
\hline & $\begin{array}{l}\text { Implement special programs to support the } \\
\text { vulnerable and the excluded } \\
\text { Prepare a social protection strategy }\end{array}$ & $\begin{array}{lr}\text { Targeting } & \text { of } \\
\text { resources } & \text { for } \\
\text { vulnerable } & \\
\text { groups } & \\
\text { improved } & \end{array}$ & & & $\begin{array}{l}\text { Draft social protection strategy } \\
\text { is being prepared }\end{array}$ & \\
\hline
\end{tabular}




\section{CHAPTER NINE}

\section{PROGRESS ON THE MILLENNIUM DEVELOPMENT GOALS}

The Millennium Declaration was adopted by Member States of the United Nations in 2002. It has eight Millennium Development Goals (MGDs), ranging from eradication of poverty to developing a global partnership for development. The government of Ghana is committed to achieving these goals. This is evidenced in the strong linkage between the MDG goals and those of the GPRS, which provides the overall policy framework for the country's development. This section of the APR provides progress towards the achievement of the MDGs. The information is essentially a reproduction of the 2004 MDG Report prepared by the NDPC.

Table 9.1: Status at a Glance, 2004 — Ghana's Progress towards the Millennium Development Goals

\begin{tabular}{|c|c|c|c|c|c|c|c|c|}
\hline \multirow{2}{*}{$\begin{array}{l}\text { Goals } \\
\text { Extreme poverty and hunger } \\
\text { Halve the proportion of people below the } \\
\text { national poverty line by } 2015 \\
\text { Halve the proportion of people who suffer } \\
\text { from hunger }\end{array}$} & \multicolumn{4}{|c|}{ Will goal be reached? } & \multicolumn{4}{|c|}{ State of supportive environment } \\
\hline & $\begin{array}{l}\text { Probably } \\
\text { Probably }\end{array}$ & $\begin{array}{l}\text { Potentially } \\
\text { Potentially }\end{array}$ & $\begin{array}{l}\text { Unlikely } \\
\text { Unlikely }\end{array}$ & $\begin{array}{l}\text { Lack of } \\
\text { data } \\
\text { Lack of } \\
\text { data }\end{array}$ & $\begin{array}{l}\text { Strong } \\
\text { Strong }\end{array}$ & $\begin{array}{l}\text { Fair } \\
\text { Fair }\end{array}$ & $\begin{array}{l}\text { Weak but } \\
\text { improving } \\
\text { Weak but } \\
\text { improving }\end{array}$ & Weak \\
\hline $\begin{array}{l}\text { Universal primary education } \\
\text { Achieve universal access to primary } \\
\text { education by } 2015\end{array}$ & Probably & Potentially & Unlikely & $\begin{array}{l}\text { Lack of } \\
\text { data }\end{array}$ & Strong & Fair & $\begin{array}{l}\text { Weak but } \\
\text { improving }\end{array}$ & Weak \\
\hline $\begin{array}{l}\text { Gender equality } \\
\text { Eliminate gender disparity in primary and } \\
\text { junior secondary education by } 2005 \\
\text { Achieve equal access for boys and girls to } \\
\text { senior secondary by } 2005\end{array}$ & $\begin{array}{l}\text { Probably } \\
\text { Probably }\end{array}$ & $\begin{array}{l}\text { Potentially } \\
\text { Potentially }\end{array}$ & $\begin{array}{l}\text { Unlikely } \\
\text { Unlikely }\end{array}$ & $\begin{array}{l}\text { Lack of } \\
\text { data } \\
\text { Lack of } \\
\text { data }\end{array}$ & $\begin{array}{l}\text { Strong } \\
\text { Strong }\end{array}$ & $\begin{array}{l}\text { Fair } \\
\text { Fair }\end{array}$ & $\begin{array}{l}\text { Weak but } \\
\text { improving } \\
\text { Weak but } \\
\text { improving }\end{array}$ & Weak \\
\hline $\begin{array}{l}\text { Under-five mortality } \\
\text { Reduce under-five mortality by two-thirds } \\
\text { by } 2015\end{array}$ & Probably & Potentially & Unlikely & $\begin{array}{l}\text { Lack of } \\
\text { data }\end{array}$ & Strong & Fair & $\begin{array}{l}\text { Weak but } \\
\text { improving }\end{array}$ & Weak \\
\hline $\begin{array}{l}\text { Maternal mortality } \\
\text { Reduce maternal mortality ratio by three- } \\
\text { quarters by } 2015\end{array}$ & Probably & Potentially & Unlikely & $\begin{array}{l}\text { Lack of } \\
\text { data }\end{array}$ & Strong & Fair & $\begin{array}{l}\text { Weak but } \\
\text { improving }\end{array}$ & Weak \\
\hline $\begin{array}{l}\text { HIV/AIDS \& Malaria } \\
\text { Halt and reverse the spread of HIV/AIDS } \\
\text { by } 2015 \\
\text { Halt and reverse the incidence of } \\
\text { malaria }\end{array}$ & $\begin{array}{l}\text { Probably } \\
\text { Probably }\end{array}$ & $\begin{array}{l}\text { Potentially } \\
\text { Potentially }\end{array}$ & $\begin{array}{l}\text { Unlikely } \\
\text { Unlikely }\end{array}$ & $\begin{array}{l}\text { Lack of } \\
\text { data } \\
\text { Lack of } \\
\text { data }\end{array}$ & $\begin{array}{l}\text { Strong } \\
\text { Strong }\end{array}$ & $\begin{array}{l}\text { Fair } \\
\text { Fair }\end{array}$ & $\begin{array}{l}\text { Weak but } \\
\text { improving } \\
\text { Weak but } \\
\text { improving }\end{array}$ & $\begin{array}{l}\text { Weak } \\
\text { Weak }\end{array}$ \\
\hline $\begin{array}{l}\text { Ensure Environmental Sustainability } \\
\text { Integrate the principles of sustainable } \\
\text { development into country policies and } \\
\text { programmes and reverse loss of } \\
\text { environmental resources } \\
\text { Halve the proportion of people without } \\
\text { access to safe drinking water by } 2015 \\
\text { By } 2020 \text { a significant improvement would } \\
\text { have been achieved in the lives of at least } \\
100 \text { million slum dwellers } \\
\text { Improving the lives of slum dwellers }\end{array}$ & Probably & Potentially & $\begin{array}{l}\text { Unlikely } \\
\text { Unlikely }\end{array}$ & $\begin{array}{l}\text { Lack of } \\
\text { data } \\
\text { Lack of } \\
\text { data }\end{array}$ & $\begin{array}{l}\text { Strong } \\
\text { Strong }\end{array}$ & Fair & $\begin{array}{l}\text { Weak but } \\
\text { improving } \\
\text { Weak but } \\
\text { improving }\end{array}$ & $\begin{array}{l}\text { Weak } \\
\text { Weak }\end{array}$ \\
\hline $\begin{array}{l}\text { Global partnership for development } \\
\text { Deal comprehensively with debt and } \\
\text { make debt sustainable in the long term }\end{array}$ & Probably & Potentially & Unlikely & $\begin{array}{l}\text { Lack of } \\
\text { data }\end{array}$ & Strong & Fair & $\begin{array}{l}\text { Weak but } \\
\text { improving }\end{array}$ & Weak \\
\hline
\end{tabular}
Source: NDPC 2004

* Lack of data implies inability to score appropriately

GOAL 1: ERADICATE EXTREME POVERTY 
Target 1: Halve the proportion of those in extreme poverty between 1990-2015 Indicator: Proportion below national basic needs, poverty line

\section{1 - Reducing Extreme Poverty:}

\section{Status and Trends}

The most recent data on the incidence of poverty in Ghana compiled in 1999 (Ghana Living Standards Survey 4) estimated a poverty rate of 39 percent. According to the survey poverty was concentrated in the Northern, Upper East and Central regions of the country and among foodcrop farmers

However, trends in the macro-economic indicators including increased sectoral growth rates and increased expenditures on povertyfocused activities point to a decline in poverty rates.

Indeed, improvements in macro-economic indicators have been associated with faster GDP growth. Furthermore, GDP growth has been led by the agricultural sector which employs the majority of the poor.

While these developments are positive indicators of declining poverty rates other factors suggest that trends in the real GDP growth must be interpreted with caution.

The 5 percent average real GDP growth over the 2002-2004 period is still well below the 7 percent rate required to significantly reduce poverty by 2015.

Furthermore, trends in the incidence of malnutrition may suggest deepening pockets of poverty in some regions of the country. The level of child malnutrition as measured by the proportion of children classified as underweight is on the rise. The incidence of underweight children rose from 25\% in 1998 to 35.8 percent in 2003. Child malnutrition is concentrated in the Ashanti (46 percent), Greater Accra (40.4 percent and Western regions (36.9 percent).

\section{2- Challenges to reducing extreme poverty}

The 2002 MDG argued that the realization of the MDG goal of halving the poverty rate by 2015 hinged on the formulation of appropriate policies, the political will to implement the policies and the ability to monitor and review policy through timely access to reliable poverty data and effective monitoring institutions.

With the formulation and implementation of the GPRS, issues with respect to policy formulation have largely been addressed. The most pressing challenges to date are in the area of policy implementation and effective monitoring.

Specifically, the critical challenges include:

- Ensuring that programmes in the GPRS are linked to the annual budget and funded as planned

- Maintaining macro-stability in the face of external shocks particularly rising crude oil prices

- The ability to fund safety nets for groups adversely affected by current and imminent policies of full cost recovery pricing in the energy sector.

- Rationalizing the public sector and reducing the relative size of the discretionary budget allocated public sector wage bill

- Addressing long term population growth through reductions in the fertility rate

- Addressing the growing risks implied by the spread of HIV/AIDS

- Sustaining the political will to implement the GPRS

Significant challenges also exist in the area of monitoring and routine data collection. For instance, currently, the Ministry of Food and Agriculture captures data for only food crops. There is a need to expand the coverage of the Annual Survey to include non-food crops.

Furthermore, there is a need to accord greater fiscal priority to monitoring and evaluation. Ensuring adequate financing of poverty monitoring initiatives and data collection at the 
district level will improve the quality and timeliness of data delivery.

\section{Supportive Environment}

Several policy measures and projects consistent with the goal of poverty reduction have been undertaken since the implementation of the GPRS in 2002. They include:

- Substantial improvements in the macroeconomic environment as evidenced by a decline in inflation and interest rates and a corresponding increase in credit to the private sector from $-11 \%$ in 2001 to $37.5 \%$ in 2003.

- Efforts to link the GPRS to the budget through the Medium Term Expenditure Framework

- Efforts to promote district-level autonomy in the implementation of their development plans through the enactment of the Local Government Bill.

- The preparation of a draft National Decentralization Action Plan and district composite budgets to operationalize the Local Government Act;

- Channelling HIPC-related expenditures to health, sanitation, education and employment-generating projects at the district level.

- In addition to providing funds to MDAs to finance district level projects, government has also directly funded district Assemblies to carry out projects that impact directly on the poor;

- Increased budgetary share of rural infrastructure expenditure

- The introduction of improved irrigation technologies and a doubling of the area of land under irrigation since 2002. The total land area under irrigation is currently estimated at $0.08 \%$.
- The enactment of the National Insurance Bill to increase access to health care and minimize the health expenditures of the poor

- The introduction of a high impact and rapid delivery programme in selected districts in the Northern and Upper East regions to reduce malnutrition and regional inequalities in under-5 and maternal mortality

- An overall increase in poverty-related expenditures. Poverty-related expenditures accounted for 27.3 percent of total government expenditure in 2004 representing a 27 percent increase over planned poverty reduction expenditures in 2003.

\section{Will Target be reached by 2015 ?}

The 2002 report noted that a real GDP growth rate of 4 percent would halve the poverty rate by 2015 without necessarily reducing the absolute number of poor people. Reducing the number of poor persons would require at least a 7 percent real growth rate.

At the time of compiling the 2002 report, real GDP growth averaged 4.3 percent over the 19952000 period. Since the implementation of the GPRS (2002-204) however, real GDP growth has increased: it averaged 5.0 percent. Linear trend estimates suggest that the current growth trajectory of approximately 5 percent per annum (in real terms) is consistent with an extreme poverty rate of approximately 6 percent in 2015 and a poverty rate of 10 percent in the same year. Given the increased growth that the economy has attained in recent years together with the strong supportive environment, it is very likely that Ghana will halve the poverty rate by 2015. It is important to caution however, trends in poverty reduction are not necessarily linear since they can be influenced by shocks, policy reversals and other unforeseen circumstances. 


\section{GOAL 2: ERADICATE EXTREME POVERTY AND HUNGER}

Target 2: Halve the proportion of people who suffer from hunger by 2015

Indicator: Prevalence of underweight children (children under-five)

\begin{abstract}
Status and Trends
Malnutrition remains a serious problem in Ghana. Protein energy malnutrition is the most prevalent nutritional disorder. Micronutrient deficiencies in Vitamin A, iodine, and iron are also quite common. The groups most vulnerable to malnutrition are children of pre-school and school going ages, pregnant women and lactating women. Hunger and malnutrition often translate into a high incidence of stunting, wasting and low weight among these groups.
\end{abstract}

Data from the 2003 GDHS indicate that child malnutrition remains a major problem. The survey results show that 30 percent of children under five are stunted and 11 percent severely wasted.

Trends in children's nutritional status indicate that efforts to reduce child malnutrition since the 1990s have had differential of impacts on the different dimensions of child malnutrition.

The level of child malnutrition as measured by the proportion of children underweight, for example, decreased slightly from $10 \%$ in 1998 to $7 \%$ in 2003. The proportion of children who are wasted also deceased from $25 \%$ in 1998 to $22 \%$ in 2003 . However, the proportion of children under five who are stunted increased from $26 \%$ in 1998 to 30 percent in 2003.

There are also marked rural-urban as well as regional differences in vulnerability to child malnutrition. Rural children are more likely to be underweight than urban children. Furthermore, children living in the three northern regions, including the Volta region also are more likely to be underweight (GDHS, 2003) than children in the other regions of the country.

As expected, the nutritional status of children correlates with poverty levels of households. Children who live in the lowest wealth quintile are at higher risk of being underweight than those from higher wealth quintiles (GDHS, 2003).

\section{Supportive environment}

A number of programmes/projects are being implemented to address the problem of malnutrition.

District Health Management Teams (DHMTs) have instituted Child Welfare Clinics to monitor children at risk of malnutrition. Such Clinics also promote and advocate exclusive breast feeding practices, engage in nutritional education and assessment and also designate deserving health facilities as Baby Friendly.

A National Plan of Action for Food and Nutrition was initiated in 1993, following the recommendation of International Conference on Nutrition. Under the Action Plan, a micronutrient deficiency control programme was established with sub-committees for iodine, Vitamin A, and iron. The programme was also complemented by the promotion of Vitamin A supplementation for pregnant and lactating mothers and children.

As part of the country's poverty reduction strategy, a community-based nutrition and food security project is currently being implemented on a pilot basis with the support of the World Bank. The project is aimed at strengthening the capacity of communities to achieve, on sustainable basis, adequate nutrition and food security, especially for pregnant and lactating women and children.

\section{Will Target be reached by 2015?}

If current trends in nutritional trends should continue, it is unlikely that Ghana will meet the MDG target of reducing by half, the incidence of underweight children by 2015 . Current trends indicate that, by 2015, the incidence of underweight children will rise by approximately 3 percentage points over the base rate of 31 percent in 1993. 


\section{GOAL 3: ACHIEVE UNIVERSAL PRIMARY EDUCATION}

Target 3: Achieve universal access to Primary education by 2015

Indicator: Net primary enrolment ratio

\section{Status and Trends}

Due to unavailability of data on net enrolment ratio, the gross primary enrolment ratio (GPER) is used here to discern trends in achieving the target of universal primary education by 2015 . The gross enrolment ratio gives an indication of level of participation in the primary education and takes into account all pupils enrolled in primary school.

Ghana has experienced steady but marginal increases in the GPER since 2001/02. The ratio increased from $83.8 \%$ in $2001 / 02$ to $85.7 \%$ in $2002 / 03$ and then to $86.3 \%$ in $2003 / 04$. Currently about one in five of eligible primary school children do not enrol in school (over two-fifths in the Northern, Upper East and Upper West regions).

Available data on retention of pupils reveals that, on average, the survival rate from primary grade 1 to primary grade 6 improved modestly from $79.9 \%$ in $2002 / 03$ to $84.7 \%$ in $2003 / 04$. Even with this improvement in survival, about $15 \%$ of all pupils who enter school drop out by primary 6 .

The factors constraining enrolment include inadequate number of schools in good condition, distance to school, and poverty.

Although the number of primary schools has increased from 12,326 in 1998 to 15,285 by 2003, most of primary school buildings are in severe state of disrepair. It is estimated that about $31.4 \%$ of public primary classrooms need rehabilitation (MoEYS, 2004).

Proximity to schools influences children's access to school, particularly in the rural areas. Fees and levies imposed by district assemblies and schools tend to prevent many children in both urban and rural areas from attending school.

Another factor that has compromised school enrolment is parental perception of a decline in the quality of education. To the extent that parents believe they are not getting good returns to their investment in their children's education in terms of quality and relevance, they will be hesitant about sending their children to school.

Progress towards improving quality of basic education has been slow and given rise to public concern. In particular pupil: core textbook ratios are falling; the national primary pupil: teacher ratio of $1: 34$ is below the internationally accepted optimum of 1:40 which ensures efficiency without compromising quality. Meanwhile, the percentage of qualified teachers has not improved sufficiently to make an impact on quality of education. Other factors that contribute to poor quality of education include poor school facilities, low level of teacher commitment due to poor working conditions, poor supervision of schools and low motivation of students.

The low quality of education is reflected in poor performance in both the Criterion Reference Test (CRT) and the Performance Monitoring Tests (PMT) conducted periodically by the Ministry of Education Youth and Sports to monitor quality of education.

Addressing the issue of quality of education will require substantial investments in the education sector. A large proportion of the financial allocations to the sector is absorbed by teachers' salaries, leaving little funds for non-salary expenditure. This has adversely affected the availability of teaching and learning materials and the level of infrastructure development.

\section{Supportive Environment}

To improve the delivery of basic education services, the Ghana Poverty Reduction Strategy (GPRS) places renewed emphasis on expanding access to basic education. Measures implemented towards achieving these objectives include the rehabilitation/development of physical infrastructure; providing incentive schemes to increase the enrolment and retention of girls; procurement and supply of teaching and learning 
materials; implementing teacher retention schemes in the most deprived districts; and increasing the resources delivered to deprived districts.

The Ministry of Education, Youth and Sports completed an Education Strategic Plan (ESP), which is informed by the GPRS, in 2003. Implementation of the ESP is expected to facilitate the achievement of the targets of the Universal Primary Education by 2015.

The government's commitment in expanding access to basic education is reflected in increased financial resources to the education sector. The execution rate of budgeted non-salary recurrent expenditure on education, for example, improved significantly from its 2002 level of $63.6 \%$ to $91 \%$ in 2003. In addition to government funding, resources from traditional authority sources (such as the Otumfuo Education Fund and the Northern Education Trust Fund) and non-governmental organisations support the financing of primary education in Ghana.

\section{Will Target be reached by 2015?}

Projections based on current trends in enrolment rates suggests that $100 \%$ gross primary school enrolment will be achieved by 2010 and net primary enrolment by 2015 . 


\title{
GOAL 3: PROMOTE GENDER EQUALITY AND EMPOWER WOMEN
}

\author{
Target 9: Eliminate gender disparity in Primary and Secondary education by 2005 \\ Indicator: Ratio of females to males in Primary, Junior and Senior Secondary schools
}

\section{Target: Achieve equal access for boys and girls to senior secondary by 2005 Indicator: Ratio of females to males in senior secondary school}

\section{Status and Trends}

Closing the persistent gender gap in education at all levels continues to be a major challenge to the education sector in Ghana. Available information points to only slow progress in achieving gender parity in education. At the primary level of education, the Gender Parity Index marginally improved from 82 females to 100 males in 1990 to 93 females to 100 males in 2003. Gender parity in the three northern regions is still below the national average but has shown marked improvement in recent years. The Upper West Region, for example, has already exceeded its GPRS target.

Gender parity is lower at the junior secondary school level than at the primary level. However, unlike the primary level, the GPI for junior secondary school improved significantly between 1990 (62 females to 100 males) and 2003 (88 females to 100 males).

Socio-cultural barriers to female enrolment in education in Ghana include poverty, direct cost of schooling, gender socialization, level of parental education and cultural and traditional practices, such as early marriage, customary fostering, puberty rites and Trokosi (female ritual slavery). Girls enrolled in school are more likely than boys to be withdrawn from school to help in household chores and family business.

\section{Supportive Environment}

In spite of challenges, concrete measures have been taken that have led to improvements in gender parity in enrolments. They include the appointment of a Minister responsible for among other things, girl-child education. A girls' Education Unit was also established in 1997 to give special emphasis to girls' education, in order to provide equal access to education and educational opportunities, and improve the status of women and girls. The Unit emphasizes increasing girls' enrolment, reducing the dropout rate for girls and increasing the transition rate for girls to senior secondary school.

Current medium term priorities of the GPRS which aim to mainstream preschool education in all basic schools has the potential to greatly enhance gross primary on admission of girls since gender disparities are practically non-existent at that level.

Other measures implemented to improve girls' enrolment at the basic level include:

- Provision of material support including school uniforms, stationery, school bags and food rations.

- Some District Assemblies are awarding scholarships to needy girls.

- An amount of 8.885 billion cedis from the GET fund was allocated to the Ministry of Education, Youth and Sports to provide scholarships for pupils in basic schools.

- Implementation of a proposed capitation grant should impact on gender parity

\section{Will Target be reached by 2005 ?}

Trends in the gender parity index reveal that the ratio of males to females in primary, junior and senior secondary schools will be approximately 94 percent by 2005 . 


\section{GOAL 4: UNDER-FIVE MORTALITY}

Target 5: Reduce under-five mortality by two-thirds by 2015

Indicator: Under-five mortality rate

\section{1-Status and Trends}

In Ghana, under-five mortality rate (U5MR) remains relatively high and has even increased slightly in the most recent five-year period. Comparison of the 1998 and 2003 Ghana Demographic and Health Surveys (GDHS) shows that U5MR increased from 108 per 1000 live births in 1998 to 111 per 1000 live births in 2003. Under the current child mortality rate of 111 per 1000 live births, one in every nine children dies before reaching age five.

There are marked socioeconomic differentials of under-five mortality in Ghana. Mortality levels in rural areas are higher than in urban areas. According to the 2003 GDHS report, U5MR in rural areas is 118 per 1000 live births compared with 93 for urban areas. Across geographical regions, U5MR ranges from 75 per 1000 live births in Greater Accra to a high of 208 in the Upper West Region. The risk of dying is also highest among children whose mothers have no education and/or have no say in household decision making.

The lack of progress in reducing under-five mortality can be attributed to the persistence over the years of six threats to children's health. These threats are high incidence of malaria, acute respiratory infections, diarrhoea, malnutrition, anaemia, measles and neonatal causes. Together, these health problems account for $50 \%$ of all childhood admissions and $30 \%$ of all childhood deaths.

Childhood mortality rates are also generally associated with demographic factors such as age of mother, birth interval and birth weight. Data from the 2003 GDHS indicate that all these factors are associated with elevated risk of mortality. Infant mortality, for example, is 50\% higher among low birth weight babies than babies of average or larger weight.

Access to safe water, adequate sanitation and safe shelter are also important correlates of child health and mortality. In Ghana less than $50 \%$ of rural population have access to safe water and sanitation (CWIQ, 2003) and housing conditions in the country, especially urban slums are characterized by high average occupancy rates and/or excessive pressure on shared facilities such as kitchens, bathrooms and toilets.

\section{Supportive Environment:}

The Ghana Poverty Reduction Strategy gives priority to the health sector and emphasizes primary health care delivery. Consequently, expenditures on health have increased. The proportion of non-wage recurrent expenditure on health has doubled in four years, from $5.7 \%$ in 2000 to $11.8 \%$ in 2003. In addition, a new expenditure allocation formula to provide additional funding for health expenditure in deprived areas has been adopted. Expenditure allocation in the new formula is based on population adjusted for health needs (as measured by the levels of IMR and U5MR). Further, under the Highly Indebted Poor Country Initiative a proportion of savings was used to enhance access to basic services of water and sanitation, education and health care.

In response to the prevailing high childhood mortality in the country, specific interventions have been implemented over the years to improve child survival and development. These include:

1. Integrated Management of Childhood Illness (IMCI): The programme involves improving the case management skills of health professionals; strengthening health systems to provide essential drugs and logistics for managing childhood diseases; and providing cost-effective interventions including the promotion of breastfeeding, use 
of ITNs, and managing diseases such as malaria, diarrhoea, and measles.

\section{Expanded Programme in Immunization} (EPI): EPI has been implemented in Ghana since 1978 through a combination of routine and mass immunization exercises. Immunization has been against the six childhood diseases (i.e., diphtheria, measles, pertussis, poliomyelitis, tuberculosis, whooping cough). Efforts to increase immunization coverage are yielding results. According to the 2003 GDHS, the proportion of children age 12-23 months who are fully vaccinated has increased over the past fifteen years, from 47\% in 1998 to $69 \%$ in 2003. However, there are large geographical variations in coverage, with coverage below the national average in rural areas and the northern part of Ghana.

3. Enhance Access to Health Services: The 2003 CWIQ shows that access to health services is a key determinant of health service utilization Implementation of a Community-based Health Planning and Services Strategy (CHPS) is the Government's strategy for addressing the disparities in health outcomes between regions by bringing services closer to people. The objective of CHPS is to move health services to community locations, developing sustainable voluntarism and community health action programs, empowering women and vulnerable groups and improving interaction between health providers, households and the community.

Other initiatives include:

- Macro-Economics and Health Initiative

- The Global Fund

- Roll back Malaria Program

- The program for accelerated control of measles, maternal and neonatal tetanus

- High Impact Rapid Delivery Program for U5MR and MMR

\section{Will Target be reached by 2005?}

Achieving the under-5 mortality target implies that mortality per 1000 live births must decline from the base figure of 155 per 1000 in 1988 to approximately 53 per 1000 live births by 2015 .

However, current trends suggest that by 2015 under- five mortality will be in the range of 65-70 per 1000 live births. Given the strong supportive environment however, it is unlikely that current trends will persist. Hence, the prognosis is that there is the potential that the target will be achieved. 


\section{GOAL 5: IMPROVE MATERNAL HEALTH}

Target 6: Reduce maternal mortality ratio by three-quarters by 2015

Indicator: Maternal mortality per 100,000

\section{1-Status and Trends}

There is little agreement on extent of maternal deaths in the country due to unavailability of reliable data. Available estimates put the level of maternal mortality from a predicted ratio of 586 (Hill, 2001) to about 210 per 100,000 live birth (WHO,1999), with considerable differences between the regions. It has been estimated, for example that the deprived northern regions have MMR over 800 maternal deaths per 100,000 live births.

The most recent information on the risks associated with the high maternal mortality in the country comes from the Maternal Health Project (1997/98). The project identified postpartum haemorrhage, severe anaemia, sepsis, and obstructed labour as important risk factors. Structural factors that impede treatment of obstructed labour such as timely transportation to health facility cost of emergency admissions and health care providers' attitudes and practices are also important contributory factors.

Efforts have been made since the early 1990s to improve the health and well being of expecting mothers and children through the Safe Motherhood Initiative (SMI). The components of the SMI include antenatal care, supervised delivery, postpartum care, family planning, and management of abortion complications.

Antenatal care coverage has been generally encouraging with over $88 \%$ of health facilities in Ghana currently offering antenatal care services. Concurrently, there has been an improvement in the utilization of professional antenatal services by pregnant women in the last fifteen years, from $82 \%$ in 1998 to $92 \%$ in 2003 . As at $2003,98 \%$ of urban women and $89 \%$ of rural women received antenatal care from trained health professionals. Most women $(69 \%)$ make at least the four recommended antenatal visits during pregnancy and the median number of months pregnant at first visit stands at 3.8 among urban residents and 4.2 among rural residents.
A professionally assisted delivery reduces the health risks associated with childbirth such as complications and infections that can cause the death of the mother and/or baby. Delivery assistance by trained health professionals continue to be low in Ghana. Nationally over half (53\%) of births still occur at home under the supervision of traditional birth attendants or elderly women. Reasons for low utilization of professional supervised delivery by mothers include problems of transportation to health facility during labour, poverty and socio-cultural beliefs that may discourage giving birth outside the home environment.

Family planning improves maternal health and it is an important component of maternal health care delivery in the country. The 2003 Ghana Demographic and Health Survey indicate that there remains a high unmet need for family planning. The survey shows that only $25 \%$ of currently married women reported using a family planning method, with only 19\% using modern methods.

Unsafe abortion contributes substantially to maternal morbidity and mortality. A woman puts her health and life at risk as a result of unsafe abortion. In Ghana the law prohibits induced abortion unless a woman's life is endangered by her pregnancy, the foetus is impaired, or other circumstances by the law courts. Consequently many induced abortions are not reported. Increasing access to abortion management and post abortion care are critical challenges that must be addressed in the context of preventing maternal mortality.

\section{Supportive Environment}

Under the primary health care system, Ghana developed a reproductive health policy and a safe motherhood programme in the early 1990s to improve the health and well being of pregnant mothers and their children. The focus of the safe 
motherhood programme is on reducing maternal morbidity and mortality through:

- Enhancing access to basic and comprehensive essential obstetric care.

- Increasing average antenatal care attendance

- Provision of post abortion care services

- Reducing unmet need in family planning. Specific strategies for achieving the MDG target include the creation of supportive policy environment, improving access to obstetric care, especially in deprived districts, improving the care

Will Target be reached by 2015 ?

Probably Potentially Unlikely Insufficient Data of the newborn and expanding adolescent health services.

The GPRS provides a framework for improving the exemption policy to cover obstetric emergencies and life-threatening pregnancy related conditions and mortality due to childhood diseases in the impoverished central and northern regions (i.e., Upper east, Upper west and Northern region). 


\section{GOAL 6: COMBAT HIV/AIDS AND MALARIA}

Target 7: Halt and reverse the spread of HIV/ AIDS by 2015

Target 8: Halt and reverse the incidence of Malaria

\section{Status and Trends}

\section{HIV/AIDS}

Sentinel surveillance data from antenatal care clinics and from individuals seeking medical treatment have been the main source of data on $\mathrm{HIV} / \mathrm{AIDS}$ prevalence in Ghana. According to information from this source, the HIV prevalence rate has consistently increased from $1.5 \%$ in 1999 to $3.6 \%$ in 2003. The National AIDS Control Programme has projected HIV prevalence rate to increase to $4.7 \%$ by $2005,8.2 \%$ by 2009 and $9.5 \%$ by 2014 if the present trend continues.

An estimated 400,000 adults and 34,000 children under age 15 are currently living with HIV/AIDS. About 200,000 children have been orphaned by the pandemic.

The age-sex distribution pattern of adult infections revealed that $90 \%$ of the cumulative AIDS cases were between the ages of 15-49 years and $63 \%$ of all reported HIV/AIDS cases were females. The peak age for females (15-34 years) is lower than that for males (30-39 years).

The main mode of transmission in Ghana is through heterosexual sex $(80 \%)$; mother- to- child transmission accounts for $15 \%$ of infections.

Commercial sex workers are the group most at risk of infection. About $75.8 \%$ and $82 \%$ respectively of commercial sex workers in the two major cities of Kumasi and Accra have been found to be HIV positive.

\section{Supportive Environment}

In September 2000, Ghana took a significant step toward mobilizing all sectors in responding to $\mathrm{HIV} / \mathrm{AIDS}$ by establishing the multi-sectoral Ghana AIDS Commission. The Commission coordinates the involvement of all public and private sector stakeholders in combating the epidemic. Specific aims are to prevent new infections among youth and other vulnerable groups; mobilize groups to support persons living with HIV/AIDS; and establish a budget line in every Ministry for HIV/AIDS activities, separate from the budget for the Commission itself.

The objectives of the Ghana HIV/AIDS Strategic Framework (2001-2005) include:

- Reduce new HIV infections among the 15-49 age group and other vulnerable groups by 30 percent;

- Improve service delivery and mitigate the impact of HIV/AIDS on individuals, families, and communities;

- Reduce individual and societal vulnerability and susceptibility to HIV/AIDS through the creation of an enabling environment for the implementation of the national response; and

- Establish a well-managed, multisectoral and multidisciplinary institutional framework for coordination and $\boldsymbol{H I V} / \boldsymbol{A I D S}$

The prohibitive cost of treatment, coupled with the potentially devastating effect of HIV/AIDS on the domestic economy suggests the need for a coordinated approach to tackling the problem.

\section{Will Target be reached by 2015?}

\section{MALARIA}

Malaria in Ghana is the leading cause of mortality and morbidity, especially among children under five and pregnant women. Malaria accounts for $44.5 \%$ of all outpatient illnesses, $36.9 \%$ of all admissions, and $13.2 \%$ of all deaths in health facilities. An estimated 800,000 children under age five die from malaria annually and it is estimated that the disease accounts for $25 \%$ of under-five mortality (which has increased over the past five years). 
Since the country attained independence in 1957, she has embarked on a number of initiatives aimed at controlling malaria. These include the creation of a National Malaria Service under the global Malaria Eradication Programme in 1961; the launching of a 5-year (1993-97) National Malaria Control Action Plan with focus on capacity building for improved disease management.

\section{Supportive Environment}

Since 1998 Ghana has committed itself to the Roll Back Malaria (RBM) initiative of WHO, which builds on the Global Malaria Strategy with a focus on Africa. The goal of the Roll Back Malaria Initiative is to halve the world's malaria burden by 2010. Consequently the country has drawn up a Medium Term Strategic Plan for Malaria Control in Ghana' (1998-2002), which seeks to improve the coverage of malaria control activity by adopting an inter-sectoral approach involving other government sectors and partnership with the private sector and the community. It has also committed itself to the Abuja Declaration on Roll Back Malaria in Africa, which similarly seeks to achieve specific targets on malaria prevention and control with time limits.

A major intervention promoted under the RBM Initiative is the use of insecticide treated nets (ITNs) as a key component of Ghana 's new strategic malaria control plan. The new National Malaria Control Programme (NMCP) in Ghana also outlines the strategy for promoting the availability of ITNs through state-private sector partnership. The malaria control programme aims to reduce mortality and morbidity due to malaria by $25 \%$ by 2008 through improved case management, implementation of multiple prevention methods, focused research and improved partnerships with relevant stakeholders. 


\section{GOAL 7: ENSURE ENVIRONMENTAL SUSTAINABILITY}

Target 9: Integrate the principles of sustainable development into country policies and programmes and reverse loss of environmental resources by 2015

Indicator: Proportion of land area covered by forest

Target 10: Halve, by 2015, the proportion of people without sustainable access to safe drinking water

Indicator: Proportion of population with sustainable access to an improved water source

\section{1 - Reversing Loss of Environmental Resources}

\section{Status and Trends}

The 2002 report observed that Ghana lost approximately 79 percent of its forest cover since the beginning of the $20^{\text {th }}$ century. Forest cover declined from 8.2 million at the beginning of the $20^{\text {th }}$ century hectares to 1.7 million hectares by the $21^{\text {st }}$ century.

Factors accounting for alarming trend have not changed since the $2002 \mathrm{MDG}$ report.

Poor enforcement of regulations on natural resource utilization, inefficient management of forest reserves and the dependence on wood-fuel by the poor have contributed immensely to forest degradation at several levels.

Weak enforcement of forestry regulations has encouraged inappropriate wildlife and farming practices.

Furthermore, inefficient management of forest reserves has contributed to the loss of forests through fire, unsustainable logging practices, indiscriminate wood-fuel extraction and forest encroachment.

Finally, environmental resource degradation arising out of mining and manufacturing activities has been on the rise due to weak enforcement of environmental and mining laws. For instance, regulations on allowable cut on timber and regulations for surface mining are currently not rigorously enforced. Indeed, chainsaw operations for timber extractions were banned temporarily because of a general failure to observe and enforce existing regulations.

\section{Supportive Environment}

Since the compilation of the 2002 report, the government has undertaken several initiatives to address the nation's environmental concerns.

\section{Deforestation}

Indicators suggest that the annual rate of deforestation has decreased from 65,000 to 50,000 hectares. Good progress towards reafforestation targets has also been made with respect to replanting in forest reserves and urban areas: 1300 hectares of urban land and 25,691 hectares of degraded forest reserves were replanted in 2003.

Healthy growth in the construction industry has contributed to the accelerated rate of deforestation through the increase in demand for building materials including wood products. To ease the demand for local supplies of wood, the government removed duties on imported round logs in 2001. In 2003 this tax relief was extended to include imports of lumber for domestic processing.

\section{Land Reform:}

To ensure easier access and more efficient land ownership and title processes the government through the Ministry of Lands and Forestry, initiated a Land Administration Program (LAP) in April 25, 2003.

The LAP will harmonise land policies and the legal framework with customary land law practices to ensure greater transparency in land administration and the enforcement of property rights.

Meanwhile, there has been some progress in land reform with respect to the issuing of Land Title 
certificates to individuals, and the establishment of 2 customary land administration units in 2003.

\section{Environmental Planning}

To ensure that environmental concerns are adequately reflected in the nation's development planning framework, the Environmental Protection Agency (EPA) in collaboration with the National Development Planning Commission (NDPC), conducted a Strategic Environmental Assessment of the Growth and Poverty Strategy Program (GPRS).

To address pollution stemming from vehicular emissions, the EPA undertook a baseline study of the Accra-Tema Metropolitan area to establish a reference point for subsequent monitoring processes.

\section{Mining}

Mining activities are a major source of environmental degradation. The use of harmful chemicals (e.g., cyanide and mercury) and explosives poses a threat to wildlife, fish and humans alike. However, few government initiatives are in place to address these serious concerns. Existing measures such as studies on mercury abatement and public awareness campaigns on the dangers of such chemicals must be complemented by a review of the comprehensiveness of existing EPA laws, rigorous enforcement of such laws and aggressive monitoring of all mining activities.

\section{Forestry and Wildife Management}

The Forestry and Wildlife Policy of Ghana aims at conservation and the sustainable development of the nation's forest and wildlife resources. In collaboration with the Ministry of Energy, the Ministry of Environment, Science \& Technology and the Ministry of Local Government \& Rural Development, the Ministry of Lands and Forestry is currently implementing a comprehensive tenyear sector investment programme: the Natural Resource Management Programme. The objective of this programme is to protect, rehabilitate and sustainably manage the national land, forest and wildlife resources through collaborative management with the rural communities that collectively own these resources. Key aspects of the programme include:
- Enhancing community involvement in the management of forest \& wildlife and savannah woodland resources and improving benefit flows to communities from resource sales

- Increasing community and farmer adoption of improved land and water management techniques

- Improving management of wildlife while increasing its contribution to local livelihoods and economic development

\section{Will Target be reached by 2015?}

The performance of government with respect to the environment is mixed. Performance is strong in the area of reafforestation but relatively weak in the area of enforcement of existing environmental regulations. The overall assessment is that Ghana has the potential to achieve the MDG on the environment. Realizing its potential will however require greater effort in the enforcement of its environmental regulations.

\section{Target 10: Water}

\section{1- Status and Trends}

The 2002 MDG report observed wide regional and rural-urban disparities in access to safe water in Ghana despite a rise in the national average from $49 \%$ in 1990 to $74 \%$ in 1998.

In 2000, the proportion of rural population with access to safe water was only $40 \%$, while that for urban areas was 70\%. Despite relatively higher urban access to safe water, supply is sporadic and unreliable.

Recent data on the status of Water and Sanitation, indicates that progress towards increasing access to safe water to the rural population is mixed.

Although the proportion of rural population with access to safe water increased from $40.0 \%$ to $46.6 \%$ over the $2000-2003$ period, reported cases of guinea worm (a water-borne 
disease) increased from 5,545 in 2002 to 8,000 in 2003 suggesting weaknesses in case containment programmes and community education on causes of the disease.

Furthermore, the level of access to safe sanitation remains very low with a national average of just over 55 percent. Access to adequate sanitation in the three northern deprived regions is around 20 percent or lower.

Communities are required to own and manage their own supply systems and contribute 5$7 \%$ of the capital costs as commitment to managing their water systems themselves. However, to accelerate rural water supply there is the need for the government to be also committed to increase investment.

Communities have the choice of technology and may install small piped systems, boreholes and/or wells. Installation is with the assistance of the Community Water and Sanitation agency and the District Assemblies.

However, rural systems are characterized by frequent break-downs and in some communities, the high salinity levels of the ground water results in the abandonment of boreholes for the traditional sources of water such as ponds, and rivers, which tend to be unsafe.

In the urban areas, the problem is a lack of consistency in water supply. There are also wide variations in access even within urban areas.

Supportive Environment

In order to improve access to safe water and sanitation and tackle the resurgence of guinea worm infestation, the government constructed 246 boreholes in guinea-worm endemic areas:

5 districts in the Northern region,

2 districts in the Brong Ahafo region

2 districts in the Volta region

Furthermore, the targeted districts have been exempted from the mandatory 5 percent community contribution to capital costs for HPIC funded water infrasructures.

In 2003, the following water delivery activities were undertaken in rural and peri-urban communities:

-1290 new boreholes were constructed

-115 boreholes were rehabilitated

-61 new hand-dug wells were constructed.

-65 small community/town pipe systems were completed.

To address the erratic water supply problem in the urban areas, the Ghana Water Company limited rehabilitated and expanded the water treatment plant in Weija and Ichaban.

\section{Will Target be reached by 2015?}

In 1990 approximately 50 percent of the nation was without access to safe water. Achieving the goal of reducing by half the number of persons without access to safe water implies increasing the access rate to 75 percent by 2015 . The national trends in access to safe water suggest that if current trends continue Ghana will exceed the MDG target; the national access rate will be over 80 percent. However, the MGD target for sanitation is not likely to be met. 
Target 11: By 2020 a significant improvement would have been achieved in the lives of at least 100 million slum dwellers.

Indicator: Proportion of households with access to secure tenure

\section{Status and trends}

Census data in Ghana indicate that the country has been experiencing rapid urbanization. The proportion of urban population, for example, has increased from a low of $33 \%$ in the 1960 s to $43.8 \%$ by 2000. The Ghana Statistical Service defines any locality with 5000 or more people as urban. On the basis of this definition, the number of settlements classified as urban also increased from 189 in 1984 to 364 in 2000. Majority (34\%) of urban settlements have a population range of 5,000 to 10,000 .

Corresponding to urban growth has been development of urban slums which are characterized by inadequate drinking water supply; inadequate sanitation facilities; lack of security of tenure; and poor quality of houses. According to UN-Habitat (2003) about 70\% of Ghana's urban population lives in slum conditions. The number of slum dwellers is expected to reach 5.8 million by 2010 . Slum areas are very pronounced in the major cities of Accra, Kumasi, Sekondi-Takoradi, Tema and Tamale. There are also pockets of slums in Cape Coast, Koforidua, Sunyani, Ho and Bolgatanga.

The most recent and comprehensive information on housing conditions in the country comes from the 2000 Population and Housing Census. Data from that Census indicated that, overcrowding; inadequate facilities; and poor sanitation are major housing issues. A typical Ghanaian household occupies a room in a compound house with an average of 2.5 people per room. Illegal occupation is also becoming a worrying phenomenon, especially in the cities.

The key factors driving the growth of urban slums include rural-urban migration, limited supply of land and lack of appropriate regulatory frameworks to guide urban development. Most rural-urban migrants are young people abandoning agriculture in the rural areas for towns and cities where jobs are not readily available. They are likely to end up in slums, putting pressure on already overstretched urban housing, water, electricity, health and sanitation

\section{Supportive environment}

To date, the Government of Ghana does not have an urban development policy. However several urban development strategies can be found in various government publications. These strategies have focused mainly on stimulating the growth of small and mediumsized towns serving rural areas and human settlement planning and management. The GPRS document, which provides the policy framework for national development, did not deal extensively with issues relating to slums and slum development. The document only mentioned slum as a cross cutting issue.

Will Target be reached by 2020 ?

Probably Potentially Unlikely Insufficient Data 


\title{
GOAL 8: DEVELOP A GLOBAL PARTNERSHIP FOR DEVELOPMENT
}

\author{
Target 15: Deal comprehensively with LDC debt and make debt sustainable in the long term \\ Indicator: Debt service as a percentage of exports
}

\section{1 -Dealing Comprehensively with Debt}

\section{Status and Trends}

Ghana's domestic and external debt service positions have improved since its accession to the HIPC initiative in 2001.

After making considerable progress in the implementation of its Poverty Reduction Strategy, Ghana reached completion point in mid-2004.

Prior to joining the HIPC initiative in 2001, the external debt was 127 percent of GDP or approximately US $\$ 5.3$ billion in 2001. Unlike the external debt, which was largely concessionary and long-term, the domestic debt consisted largely of 91-day Treasury Bills contracted at commercial interest rates. Consequently, the debt service burden of the domestic debt posed a severe fiscal problem for government.

Furthermore, due to poor debt monitoring mechanisms, particularly with respect to debt contracted by state-owned agencies, estimates of government contingent liabilities were poor.

In response to this problem, the government carried out nationwide forensic audits of public institutions to arrive at a reliable estimate of the domestic debt.

By 2003, the domestic debt burden (i.e., the debt to GDP ratio) had declined to $22.6 \%$ in 2003; down from $29.1 \%$ in 2002. This reduction in domestic debt helped reduce inflation and lending rates. As a result, credit growth to the private sector increased from $11 \%$ in 2001 to $37.5 \%$ in 2003 . Lower interest rates in turn reduced government's domestic debt service burden.

\section{3- Supportive Environment}

Since the 2002 MDG report, government has deepened efforts to reduce its debt burden through debt restructuring, expenditure management, improved domestic resource mobilization and the pursuit of stable price and exchange rate policies.

To reduce its total debt burden to sustainable levels, the country requested debt relief under the enhanced HIPC initiative in 2001. Concurrently the government drafted a Growth and Poverty Reduction Strategy to promote sustainable broad-based growth.

To minimize the domestic debt burden, 20 percent of savings from HIPC was applied to the domestic debt. By 2003 the domestic debt stock had declined from 17 percent of GDP to 16.1 percent of GDP.

The government further reduced its domestic debt burden by increasing revenue collection through improvements in the efficiency of revenue collecting agencies. Consequently, the revenue to GDP ratio rose from 20.7 to $21.3 \%$ between 2002 and 2003. On the other hand, expenditure to GDP ratios recorded relatively lower growth rates of 18.5 and 18.8 percent in 2002 and 2003 respectively, resulting in an improvement in the fiscal balance.

However, government's decision to use the TOR Debt Recovery Fund, to subsidize petroleum prices is likely to increase the domestic debt.

Expenditure management measures currently in place include the installation of an expenditure tracking system on a pilot basis in the Ministry of Finance and the training of Budget Committees of Ministries 
Departments and Agencies (MDAs) on the need for the budget to be driven by the priorities of the GPRS.

The passage of the Financial Administration Bill into law (2003) strengthened the legal framework governing public expenditure while the introduction of the Tax Identification Number potentially minimized the incidence of income and corporate tax evasion.

Passage of the Banking Law which restricted government borrowing to $10 \%$ of expected revenues has also been effective in controlling excessive borrowing on the part of government.

Furthermore, a new procurement code has been established with the passage of the procurement Act in December 2003 to ensure greater transparency in procurement.
However, the government failed to follow through on its commitment to petroleum pricing reform. As a result, it continued to subsidize fuel prices even as world market prices reached record highs of approximately $\$ 55$ per barrel.

\section{Will Target be reached by 2015?}

The most recent debt sustainability analysis (DSA) of Ghana by IMF over the projection period 2004-2023 reveals a relatively sustainable external debt position. The Net Present Value of external debt-exports ratio is expected to decline from 200 percent at the end of 2003 to approximately 113 percent by 2015. The debt service to export ratio will however experience only modest decline over 2004-2015 period. These trends suggest a cautiously optimistic debt sustainability outlook for the future. 


\section{APPENDIX I}

\section{COMMENTS/FEEDBACK ON THE GPRS AND APR IN 2004}

\section{1) Feedback from the National Economic Dialogue}

\section{GENERAL COMMENTS}

- National mobilisation behind the GPRS will prove the acceptance of GPRS s grounded strategy for national development and therefore additional efforts to mobilise various stakeholders are necessary

- Poverty Reduction programs need to be speeded up, short and medium term interventions need to be considered for the poor, while growth on long term is being promoted

- Change need to be de-mystified and be made an ingredient for development; positive socio-cultural values need to be identified which can impact positively on the GPRS

- Gender issues need to be treated in all sectors as cross cutting issues and gender/age disaggregated data are needed for targeted planning at all levels. Socio-cultural factors underpinning gender issues need to be articulated in poverty reduction documents and policies

- Environmental issues need to be mainstreamed in all thematic areas

- More resources required for funding poverty reduction programs (domestic and new resources)

- Promote inter-sectoral approach of GPRS programs to improve cost effectiveness and impact.

\section{PRODUCTION AND EMPLOYMENT}

- Employment targets should be set for each region

- Issuance of land title certificates and land tenure system to be reviewed

- Review interest rates and incentives for local producers; restrict cheap imported goods. Reliable supply of water/energy and concessionary rates for energy for manufacturers required; introduce tax breaks (VAT; import duty) for new businesses importing machinery and raw materials

- Enhance the output of small scale food producers (buying centres, investments in storage facilities, agroprocessing facilities, improve market access); Agro-processing be made attractive; commodity markets for selected crops should be established

- Farmers should be educated on ICT as a complement to work of extension service agents

- Adequate provisions for funding for Research and Development and prioritise agriculture

- Promote environmentally friendly manufacturing equipment

- Concentrate on areas with comparative advantage, form exporting clusters to improve efficiency and educate businesses on international export standards.

- Formulate national policy to incorporate informal sector, improve data collection on informal sector businesses; banks should invest percentage of their loan portfolio in SME's, rural banks be modelled on the experiences of Grameen Bank (Bangladesh) to be effective in granting loans to SME's, information on credits channelled through MDAs be made available to SME's

- Support artisanal fishermen; new Fisheries Law to be enforced to manage national fish stock

- Ghana Standards Board should certify other products in addition to fish and fish products

- More emphasis on rail transport in the GPRS to help open up the farming areas

- More emphasis should be put on energy conservation and efficient energy use

\section{EDUCATION}

- Focus on improving district level management and accountability

- Partnerships (households, community and government) in education; involve communities in supervision

- Publish info on resources provided to schools and annual comparative table of school performance

- Teacher Training Colleagues need to be upgraded and adequately equipped

- Importance of retention of girls in school needs to be re-emphasized and supported: Girl child education retention in school up to the secondary levels is crucial and should be promoted and supported 
- Reconsider the idea of provision of one school meal to improve access and retention

- Review and enhance teacher pension.

\section{HEALTH}

- The mandatory retirement age or health professional should be extended to 65 years.

- Shorten recruitment process of staff and measures to be put in place to dramatically increase intake; expand and rehabilitate existing training institutions

- New professionals should be assisted in setting up private practices if they so desire

- Convert existing non-functioning public institutions into private/quasi-governmental ones

- More community-based health workers such as community health nurses should be trained

- Get more doctors out of headquarters into health delivery centres

- Improve incentives for health personnel through adequate tooling, accommodation and school facilities for their wards (at least one model basic school in each district)

- Community dialogues/assessments to identify/target the poor, and target those for support

- High impact rapid delivery program implemented successfully in some regions be expanded nationwide

- Good personal hygiene \&environmental sanitation to be emphasized as key health messages

- Good eating habits and safe water use should be promoted, smoking be banned in public areas.

\section{WATER AND SANITATION}

- Promote private sector participation

- Inter and intra-sectoral coordination needs to be improved

- A sustained campaign on sanitation is required

\section{HIV/AIDS}

- Change messages to shock people, since people become complacent seeing the same mild messages.

- Re-emphasize abstinence and delay of age of first sex, while promoting increased condom distribution; distribution of condoms nationwide should be urgently stepped up, and consider free distribution

- Promote integrated peer-based approaches that reach a greater number of high-risk groups

- Voluntary counselling/testing should be promoted and existing services more youth-friendly

- Dramatically expand programs to prevent mother-to-child transmission

- More resources are required to be provided for the care of people living with HIV/AIDS, politicians need to speak out on the subject of HIV/AIDS, support programs to reduce stigmatisation

- Increase funding for research on traditional medicines and HIV/AIDS treatment

- Integrate population issues in planning; DA's should integrate population issues in local planning as well.

\section{GOOD GOVERNANCE}

- Decentralization process must be deepened to serve as a framework for popular empowerment

- Improve capacity of DA: increase funding levels/revenue mobilization, expand materials logistics

- Integrate women and the marginalized into the political process, particularly at the local levels

- Local Government Act should be made operational; harmonize laws concerning decentralization

- Strengthen institutions at the sub-district level and encourage self-help strategies

- Revisit provisions against partisan politics in local governance; note growing demand for local politics

- Measures to ensure accountability of the various MDAs should be clarified and codified

- Enhance capacity of anti-corruption institutions through capacity building/provision adequate human and logistical resources; anti-corruption campaigns should focus on middle and lower level bureaucrats

- Parliamentary oversight must be strengthened: e.g. Assurances and Public Accounts committees should be encouraged and empowered to work effectively

- Government should expand public consultations on public policies

- Intensify government programmes such as Meet the Press series and the People's Assembly

- Annual Auditor Generals Report's recommendations to be implemented (including corruption issues) 
- Civil Service to be made accountable/efficient: outcomes Public Service Reform Program be published

- Monitoring and evaluation systems in the public service should be strengthened

- Vigilance of CSO's in monitoring public officials

- GPRS to include support for accountability/ anti-corruption institutions (SFO, CHRAJ, EC, Prisons, etc.)

- Review the Rules of Court and strengthen the Attorney General's capacity for independent prosecution

- Proper coordination among Criminal Justice Agencies: Police, Judiciary, Prisons

- Speed up court automation process and enforce Rule of Law in chieftaincy matters

- Improve access to justice for the poor and vulnerable and expand "Legal Aid" services

- Activate Article 22 (Property Rights Bill)

- Enhance law enforcement staff (service conditions of personnel, logistics)

- "Demystify" the Executive: reduce agencies and streamline functions

- Parliament: Executive intrusion must be curbed and constitutional requirement for appointing majority of Ministers from Parliament should be revisited. Parliament should be made independent of the Executive

- Judiciary should seek to eradicate the public perception of corruption

- Civil Service: build capacity, eradicate corruption, improve service

- Democratic institutions (CHRAJ, NMC, EC, NCCE): adequate resources (financial and human) should be provided and autonomy to be enhanced

- Improved coordination and information flow between the institutions, avoid duplication

\section{CIVIL SOCIETY AND THE MEDIA}

- High illiteracy rate hampers effective civil society action, therefore illiteracy rates to be reduced

- Increase local empowerment through civil society actions at the district and local level

- Strengthen role of media in accountability and transparency, and enhance professionalism

- Ghana News Agency to be strengthened for effective collection/dissemination of credible information.

\section{SECURITY OF CITIZENS}

- Communal conflicts: codify succession to stools/skins to avoid mischief in chieftaincy affairs. The Land Registry system should also be modernized to prevent conflicts over land ownership

- Research on conflict prevention and management must be encouraged

- IPAC to be strengthened to enhance relations; parties to avoid politicisation of national interest issues

- Traditional institutions and mechanisms for conflict management should be strengthened

- The Media to promote peace and conflict resolution

- The National Reconciliation Commission process be expanded to include areas that are conflict-prone

- Peace Education should be introduced in school curricula from the primary level.

\section{VULNERABLE AND EXCLUDED}

- Urgent measures required to alleviate poverty of women, especially rural/ urban poor women, disadvantaged children, unskilled youth, disabled people, old people without pensions, those with chronic diseases, refugees, widows and single parent households

- Holistic programs required supporting empowerment of women, addressing various needs of women

- Review credit schemes for women (funds often too limited to make an impact) and replicate best practices elsewhere, with priority to poverty endemic areas

- Consider explicitly the needs of illiterate women, impoverished, divorced and widowed older women

- Step up efforts to prevent increase in numbers of street children, and support special programs to re-integrate street children in society

- Ensure adequate resources for institutions dealing with women and children (MOWAC, DSW, Legal Aid Board, WAJU etc)

2) Feedback from the National Training of Trainer's Workshop

- NDPC should have a system of assessing policies before implementing it to ensure synergy of policies 
- GPRS should be the guaranteed and continued focus of government's development agenda for reducing poverty, slowing down because of change in Government should be avoided

- Why it that most of the statistics presented in the GPRS is are not disaggregated by gender? For example, there is a need to disaggregate data in relation to employment, food crop production etc so that it becomes clear how many women are really benefiting from the GPRS.

- The anti - corruption campaign should be an important component of Good governance and be highlighted in the GPRS. The rule of law should also be emphasized.

\section{3) Feedback from the Regional Dissemination of the APR}

- Ghana Water and Sanitation Agency needs to re-consider its threshold for facility location, especially in periurban communities to reduce undue pressure on facilities and subsequent high break-down rates

- Ghana Water and Sanitation Agency to place more emphasis on the education of beneficiaries to deal with entrenched cultural beliefs which encourage the use of untreated sources of water

- The usually long period between the application and disbursement of micro-credit leads to the use of such funds for other things, indebtedness, and undermines revolving credit schemes.

- Assertion that interest rates were reducing was contested: average lending rates was around $35 / 6 \%$.

- Intensification of dissemination of information on the GPRS

- Avoid inappropriate targeting, resulting in the wrong people (political supporters of ruling party, relatives of district administrators) benefiting from the programmes instead of the poor. Ignorance about on-going programmes is also a contributory factor: step up dissemination of information on on-going programmes.

- The implementation of programmes by parent ministries instead of district assemblies was felt to be at odds with decentralisation process and capacity building at the local level, and has to be reviewed

- Questions about participation in NHIS when one re-locates and how it will cater for the aged

- Questions about the aged not benefiting from exemption policy in some hospitals in the northern region

- More funding required for rural agricultural development, especially for women farmers, enhanced accessibility to producing areas, and agro-processing initiatives

- Investigate and eliminate escalating levels of school fees due to unauthorised charging of school fees

- Request for extension of PSIA's to various parts of the country: cassava/oil palm (Volta Region); millet (N. Region)

\section{4) Feedback from the ISD Community Fora}

Cinema vans toured thirty communities in all the 110 districts of the country, sensitising them on the GPRS, births and deaths registration, the NHIS, and the need for tolerance before and after the 2004 elections.

- Poverty Reduction programmes should be geared towards support for women in agriculture, especially in the rural communities since the bulk of vulnerable women and children are found in those areas

- Public education on GPRS should be stepped up; all DA's and staff should be sensitised on the GPRS, good governance and private sector development to get more public attention

- ISD should be adequately resourced to ensure regular and sustained visits to the rural communities with information on government policies and programmes.

- Reports of alleged corrupt practices in release of funds for poverty reduction programmes by officials at the Metropolitan, Municipal and District Assemblies should be investigated. 
APPENDIX II

RECORD OF BILLS - FOURTH SESSION-THIRD PARLIAMENT OF THE FOURTH REPUBLIC OF GHANA2004

\begin{tabular}{|c|c|c|c|c|c|c|c|c|c|}
\hline SHORT TITLE & $\begin{array}{l}\text { PRESENTED BY } \\
\text { MINISTER FOR: }\end{array}$ & $\begin{array}{l}\text { DATE OF } \\
\text { FIRST } \\
\text { READING }\end{array}$ & $\begin{array}{l}\text { DATE OF } \\
\text { COMMITTEE } \\
\text { REPORT }\end{array}$ & $\begin{array}{l}\text { DATE OF } \\
\text { SECOND } \\
\text { READING }\end{array}$ & $\begin{array}{c}\text { DATE OF } \\
\text { CONSIDERATION } \\
\text { STAGE } \\
\end{array}$ & $\begin{array}{l}\text { DATE OF } \\
\text { THIRD } \\
\text { READING }\end{array}$ & $\begin{array}{l}\text { DATE OF } \\
\text { ASSENT }\end{array}$ & $\begin{array}{l}\text { ACT } \\
\text { No. }\end{array}$ & $\begin{array}{l}\text { REMAR } \\
\text { KS }\end{array}$ \\
\hline 1. Insolvency Bill & $\begin{array}{c}\text { Attorney- } \\
\text { General and } \\
\text { Minister for } \\
\text { Justice }\end{array}$ & $6 / 503$ & $26 / 10 / 04$ & & & & & & \\
\hline 2. Copyright Bill & “ & $6 / 503$ & $8 / 7 / 04$ & $13 / 7 / 04$ & $21 / 12 / 04$ & $22 / 12 / 04$ & & & \\
\hline 3. Interpretation Bill & $\begin{array}{c}\text { Attorney- } \\
\text { General and } \\
\text { Minister for } \\
\text { Justice }\end{array}$ & $12 / 6 / 03$ & & & & & & & \\
\hline 4. Road Traffic (Amendment) Bill & $\begin{array}{l}\text { Roads and } \\
\text { Transport }\end{array}$ & $2 / 12 / 03$ & $15 / 6 / 04$ & $17 / 6 / 04$ & & & & & \\
\hline 5. Development and Classification of Films Bill & $\begin{array}{c}\text { Majority Leader } \\
\text { and Minister for } \\
\text { Parliamentary } \\
\text { Affairs }\end{array}$ & $27 / 1 / 04$ & $29 / 6 / 04$ & $2 / 7 / 04$ & $\begin{array}{c}7 / 7 / 04 \\
8 / 7 / 04 \\
12 / 10 / 04\end{array}$ & $13 / 10 / 04$ & & & \\
\hline 6. University of Education, Winneba, Bill & “ & “ & $3 / 3 / 04$ & $5 / 3 / 04$ & $10 / 3 / 04$ & $11 / 3 / 04$ & $14 / 5 / 04$ & 672 & \\
\hline 7. Value Added Tax (Amendment) Bill, 2003 & “ & “ & $11 / 3 / 04$ & $12 / 3 / 04$ & $12 / 3 / 04$ & $12 / 3 / 04$ & $23 / 4 / 04$ & 670 & \\
\hline 8. The Internal Revenue (Amendment) Bill & $\begin{array}{c}\text { Finance and } \\
\text { Economic } \\
\text { Planning }\end{array}$ & $5 / 3 / 04$ & $11 / 3 / 04$ & $11 / 3 / 04$ & $11 / 3 / 04$ & $11 / 3 / 04$ & $5 / 4 / 04$ & 669 & \\
\hline $\begin{array}{l}\text { 9. Customs and Excise (Duties and Other Taxes) } \\
\text { (Amendment) Bill }\end{array}$ & “ & $5 / 3 / 04$ & $11 / 3 / 04$ & $11 / 3 / 04$ & $11 / 3 / 04$ & $11 / 3 / 04$ & $5 / 4 / 04$ & 668 & \\
\hline \multirow[t]{2}{*}{ 10. Value Added Tax (Amendment) Bill, 2004} & “ & $5 / 3 / 04$ & $11 / 3 / 04$ & $11 / 3 / 04$ & $11 / 3 / 04$ & $11 / 3 / 04$ & $23 / 4 / 04$ & 671 & \\
\hline & Attorney- & $9 / 3 / 04$ & & & & & & & \\
\hline
\end{tabular}




\begin{tabular}{|c|c|c|c|c|c|c|c|c|c|}
\hline SHORT TITLE & $\begin{array}{l}\text { PRESENTED BY } \\
\text { MINISTER FOR: }\end{array}$ & $\begin{array}{l}\text { DATE OF } \\
\text { FIRST } \\
\text { READING }\end{array}$ & $\begin{array}{l}\text { DATE OF } \\
\text { COMMITTEE } \\
\text { REPORT }\end{array}$ & $\begin{array}{l}\text { DATE OF } \\
\text { SECOND } \\
\text { READING }\end{array}$ & $\begin{array}{c}\text { DATE OF } \\
\text { CONSIDERATION } \\
\text { STAGE }\end{array}$ & $\begin{array}{l}\text { DATE OF } \\
\text { THIRD } \\
\text { READING }\end{array}$ & $\begin{array}{c}\text { DATE OF } \\
\text { ASSENT }\end{array}$ & $\begin{array}{l}\text { ACT } \\
\text { No. }\end{array}$ & $\begin{array}{l}\text { REMAR } \\
\text { KS }\end{array}$ \\
\hline $\begin{array}{l}\text { 11. Representation of the People (Amendment) } \\
\text { Bill }\end{array}$ & $\begin{array}{c}\text { General and } \\
\text { Minister for } \\
\text { Justice }\end{array}$ & & & & & & & & \\
\hline 12. 2003 Supplementary Appropriation Bill & $\begin{array}{c}\text { Finance and } \\
\text { Economic } \\
\text { Planning } \\
\end{array}$ & $10 / 3 / 04$ & $11 / 3 / 04$ & $11 / 3 / 04$ & $11 / 3 / 04$ & $11 / 3 / 04$ & $30 / 3 / 04$ & 665 & \\
\hline 13. Appropriation Bill 2004 & $\begin{array}{l}\text { Finance and } \\
\text { Economic } \\
\text { Planning } \\
\end{array}$ & $10 / 3 / 04$ & $11 / 3 / 04$ & $11 / 3 / 04$ & $11 / 3 / 04$ & $11 / 3 / 04$ & $30 / 3 / 04$ & 666 & \\
\hline 14. Courts (Amendment) Bill & $\begin{array}{l}\text { Attorney- } \\
\text { General and } \\
\text { Minister for } \\
\text { Justice }\end{array}$ & $9 / 6 / 04$ & $24 / 6 / 04$ & $2 / 7 / 04$ & $13 / 7 / 04$ & $15 / 7 / 04$ & $1 / 11 / 04$ & 674 & \\
\hline 15. Long Term Savings Plans Bill & $\begin{array}{c}\text { Finance and } \\
\text { Economic } \\
\text { Planning }\end{array}$ & $9 / 6 / 04$ & & & & & & & $\begin{array}{l}\text { Withdrawn } \\
8 / 10 / 04\end{array}$ \\
\hline 16. Minerals and Mining Bill & $\begin{array}{c}\text { Majority Leader } \\
\text { and Minister for } \\
\text { Parliamentary } \\
\text { Affairs }\end{array}$ & $17 / 6 / 04$ & & & & & & & \\
\hline 17. Road Traffic Bill & $\begin{array}{l}\text { Roads and } \\
\text { Transport }\end{array}$ & $25 / 6 / 04$ & $20 / 10 / 04$ & $26 / 10 / 04$ & $\begin{array}{l}3 / 11 / 04 \\
4 / 11 / 04 \\
\end{array}$ & $4 / 11 / 04$ & $24 / 12 / 04$ & 683 & \\
\hline 18. Volta River Development (Amendment) Bill & $\begin{array}{c}\text { Majority Leader } \\
\text { and Minister for } \\
\text { Parliamentary } \\
\text { Affairs }\end{array}$ & $6 / 7 / 04$ & $3 / 11 / 04$ & & & & & & \\
\hline 19. Ghana Maritime Security Bill & $\begin{array}{l}\text { Ports, Harbours } \\
\text { and Railways }\end{array}$ & $29 / 6 / 04$ & $6 / 7 / 04$ & $6 / 7 / 04$ & $6 / 7 / 04$ & $6 / 7 / 04$ & $1 / 11 / 04$ & 675 & $\begin{array}{c}\text { Passed } \\
\text { under } \\
\text { Certificate } \\
\text { of Urgency }\end{array}$ \\
\hline 20. Ghana Meteorological Agency Bill & Communication & $12 / 10 / 04$ & $26 / 10 / 04$ & $28 / 10 / 04$ & $2 / 11 / 04$ & $3 / 11 / 04$ & $1 / 12 / 04$ & 682 & \\
\hline 21. Civil Aviation Bill & $\begin{array}{c}\text { Roads and } \\
\text { Transport }\end{array}$ & “ & $15 / 10 / 04$ & $19 / 10 / 04$ & $\begin{array}{l}26 / 10 / 04 \\
27 / 10 / 04 \\
\end{array}$ & $29 / 10 / 04$ & & 678 & \\
\hline
\end{tabular}




\begin{tabular}{|c|c|c|c|c|c|c|c|c|c|}
\hline SHORT TITLE & $\begin{array}{l}\text { PRESENTED BY } \\
\text { MINISTER FOR: }\end{array}$ & $\begin{array}{l}\text { DATE OF } \\
\text { FIRST } \\
\text { READING }\end{array}$ & $\begin{array}{l}\text { DATE OF } \\
\text { COMMITTEE } \\
\text { REPORT }\end{array}$ & $\begin{array}{l}\text { DATE OF } \\
\text { SECOND } \\
\text { READING }\end{array}$ & $\begin{array}{l}\text { DATE OF } \\
\text { CONSIDERATION } \\
\text { STAGE }\end{array}$ & $\begin{array}{l}\text { DATE OF } \\
\text { THIRD } \\
\text { READING }\end{array}$ & $\begin{array}{l}\text { DATE OF } \\
\text { ASSENT }\end{array}$ & $\begin{array}{l}\text { ACT } \\
\text { No. }\end{array}$ & $\begin{array}{l}\text { REMAR } \\
\text { KS }\end{array}$ \\
\hline & & & & & $29 / 10 / 04$ & & & & \\
\hline $\begin{array}{l}\text { 22. Internal Revenue (Registration of Business) } \\
\text { Bill }\end{array}$ & $\begin{array}{c}\text { Finance and } \\
\text { Economic } \\
\text { Planning }\end{array}$ & “ & $14 / 12 / 04$ & $21 / 12 / 04$ & $\begin{array}{l}21 / 12 / 04 \\
22 / 12 / 04\end{array}$ & $22 / 12 / 04$ & $6 / 1 / 05$ & 684 & \\
\hline 23. Stamp Duty Bill & “ & “ & $14 / 12 / 04$ & $21 / 12 / 04$ & $22 / 12 / 04$ & $22 / 12 / 04$ & & & \\
\hline 24. Venture Capital Trust Fund Bill & “ & $12 / 10 / 04$ & $15 / 10 / 04$ & $19 / 10 / 04$ & $\begin{array}{c}29 / 10 / 04 \\
1 / 11 / 04 \\
\end{array}$ & $3 / 11 / 04$ & & & \\
\hline 25. Long-Term Savings Scheme Bill & “ & “ & $15 / 10 / 04$ & $19 / 10 / 04$ & $26 / 10 / 04$ & $28 / 10 / 04$ & & 679 & \\
\hline $\begin{array}{l}\text { 26. Ghana Institute of Management and Public } \\
\text { Administration Bill }\end{array}$ & $\begin{array}{l}\text { Education, } \\
\text { Youth and } \\
\text { Sports }\end{array}$ & $18 / 10 / 04$ & $26 / 10 / 04$ & $28 / 10 / 04$ & $1 / 11 / 04$ & $2 / 11 / 04$ & & 676 & \\
\hline $\begin{array}{l}\text { 27. University of Mines and Technology, Tarkwa } \\
\text { Bill }\end{array}$ & “ & $18 / 10 / 04$ & $26 / 10 / 04$ & $28 / 10 / 04$ & $2 / 11 / 04$ & $3 / 11 / 04$ & & 677 & \\
\hline 28. West African Gas Pipeline Bill & Energy & $19 / 10 / 04$ & $27 / 10 / 04$ & $29 / 10 / 04$ & $2 / 11 / 04$ & $3 / 11 / 04$ & $1 / 12 / 04$ & 681 & \\
\hline
\end{tabular}


DISTRICT ASSEMBLIES IGF ITEM OUTTURN FOR 2000

\begin{tabular}{|c|c|c|c|c|c|c|c|c|}
\hline REGION & RATES & LANDS & FEES \& FINES & LICENCES & RENT & IN VESTMENT & UISCELLANEOUS & TOTAL \\
\hline WESTERN & $1,147,078,845$ & $3,308,668,443$ & $776,210,737$ & $1,032,257,851$ & $657,945,908$ & $163,068,568$ & $236,173,386$ & $7,321,403,738$ \\
\hline CENTRAL & $520,693,653$ & $470,936,834$ & $1,067,710,570$ & $438,064,619$ & $151,775,260$ & $106,810,149$ & $871,489,012$ & $3,627,480,097$ \\
\hline GREATER ACCRA & $9,454,672,382$ & $1,871,832,867$ & $10,775,000,290$ & $6,415,756,753$ & $535,404,643$ & $634,670,817$ & $1,062,709,552$ & $30,750,047,304$ \\
\hline EASTERN & $595,819,441$ & $219,380,500$ & $1,850,319,584$ & $541,265,899$ & $565,110,045$ & $133,488,912$ & $871,090,618$ & $4,776,474,999$ \\
\hline VOLTA & $572,980,113$ & $105,529,570$ & $1,404,859,532$ & $417,097,510$ & $205,443,828$ & $329,286,864$ & $758,809,408$ & $3,794,006,825$ \\
\hline A SHANTI & $2,196,049,323$ & $1,640,656,320$ & $3,602,869,210$ & $1,305,871,265$ & $167,920,052$ & $374,926,735$ & $1,255,024,330$ & $10,543,317,235$ \\
\hline BRONG AHAFO & $748,259,888$ & $437,555,570$ & $2,316,276,457$ & $481,634,868$ & $67,402,344$ & $227,066,830$ & $510,730,136$ & $4,788,926,093$ \\
\hline NORTHERN & $225,283,826$ & $59,927,523$ & $650,910,275$ & $201,334,741$ & $86,391,890$ & $193,820,534$ & $282,467,504$ & $1,700,136,293$ \\
\hline UPPER WEST & $127,291,485$ & $9,999,580$ & $413,880,551$ & $36,567,700$ & $23,996,595$ & $376,283,680$ & $206,505,040$ & $1,194,524,631$ \\
\hline \begin{tabular}{|l} 
UPPER EAST \\
\end{tabular} & $51,911,094$ & $\begin{array}{r}15,743,700 \\
\end{array}$ & $983,629,738$ & $94,355,700$ & $63,223,501$ & $50,601,663$ & $601,262,530$ & $\frac{1,860,727,926}{1,257}$ \\
\hline \begin{tabular}{|l} 
TOTAL \\
\end{tabular} & $15,640,040,050$ & $8,140,230,907$ & $23,841,666,944$ & $10,964,206,906$ & $2,524,614,066$ & $2,590,024,752$ & $6,656,261,516$ & $70,357,045,141$ \\
\hline \multicolumn{9}{|c|}{ DISTRICT ASSEMBLIES IGF ITEM OUTTURN FOR 2001} \\
\hline REGION & RATES & LANDS & FEES \& FINES & LICENCES & RENT & INVESTMENT & IISCELLANEOUS & TOTAL \\
\hline WESTERN & $2,434,577,390$ & $2,452,072,156$ & $1,064,236,172$ & $1,696,263,210$ & $828,339,715$ & $105,544,427$ & $361,872,211$ & $8,942,905,281$ \\
\hline CENTRAL & $843,563,366$ & $354,786,832$ & $1,415,629,713$ & $726,923,229$ & $220,504,950$ & $165,022,495$ & $1,303,759,639$ & $5,030,190,224$ \\
\hline GREATER ACCRA & $11,675,821,545$ & $298,912,084$ & $16,182,497,133$ & $8,098,348,315$ & $1,376,811,203$ & $1,731,727,130$ & $1,991,218,532$ & $41,355,335,942$ \\
\hline EASTERN & $631,121,584$ & $720,664,305$ & $2,454,406,396$ & $721,659,414$ & $314,986,510$ & $187,780,528$ & $640,948,480$ & $5,671,567,217$ \\
\hline VOLTA & $738,183,077$ & $128,436,070$ & $1,859,704,220$ & $534,454,663$ & $215,204,292$ & $512,939,452$ & $1,048,611,219$ & $5,037,532,993$ \\
\hline ASHANTI & $3,909,179,304$ & $2,384,223,300$ & $4,987,192,141$ & $2,417,026,145$ & $318,903,121$ & $222,708,872$ & $720,743,540$ & $14,959,976,423$ \\
\hline BRONG AHAFO & $1,100,734,915$ & $1,006,039,639$ & $2,756,615,255$ & $665,724,230$ & $88,362,371$ & $200,296,845$ & $687,763,884$ & $6,505,537,139$ \\
\hline NORTHERN & $290,054,751$ & $79,852,548$ & $886,943,272$ & $291,346,139$ & $137,607,070$ & $506,487,575$ & $301,681,235$ & $2,493,972,590$ \\
\hline UPPER WEST & $220,668,696$ & $\begin{array}{r}8,539,000 \\
20\end{array}$ & $385,294,734$ & $\begin{aligned} 32,890,650 \\
123,912,354\end{aligned}$ & $18,719,263$ & $291,818,509$ & $\begin{array}{r}197,485,232 \\
2\end{array}$ & $1,155,416,084$ \\
\hline \begin{tabular}{|l} 
UPPER EAST \\
TOTAL \\
\end{tabular} & $\begin{array}{r}78,632,920 \\
21,922,537,548\end{array}$ & $\begin{array}{r}22,849,455 \\
\mathbf{7 , 4 5 6 , 3 7 5 , 3 8 9}\end{array}$ & $\begin{array}{r}1,142,880,559 \\
33,135,399,595\end{array}$ & $\frac{123,912,354}{15,308,548,349}$ & $\begin{array}{r}106,501,175 \\
3,625,939,670\end{array}$ & $\begin{array}{r}78,907,541 \\
4,003,233,374\end{array}$ & $\frac{2,979,569,994}{10,233,6533,966}$ & $\begin{array}{r}4,533,253,998 \\
95,685,687,891\end{array}$ \\
\hline \multicolumn{9}{|c|}{ DISTRICT ASSEMBLIES IGF ITEM OUTTURN FOR 2002} \\
\hline REGION & RATES & LANDS & FEES \& FINES & LICENCES & RENT & INVESTMENT & MISCELLANEOUS & TOTAL \\
\hline WESTERN & $3,747,159,427$ & $7,381,936,637$ & $1,556,543,460$ & $2,667,860,183$ & $805,353,740$ & $182,713,551$ & $974,086,023$ & $17,315,653,021$ \\
\hline CENTRAL & $1,524,729,674$ & $687,700,860$ & $1,940,385,434$ & $1,318,187,570$ & $251,705,200$ & $128,175,677$ & & $6,750,070,251$ \\
\hline GREATER ACCRA & $13,347,088,282$ & $365,743,376$ & $18,024,049,755$ & 10,972, & $1,763,761,045$ & 29 & 6,94 & $52, \mathrm{C}-2$ \\
\hline EASTERN & $2,997,336,866$ & $1,132,671,832$ & $3,712,345,713$ & $1,163,687,779$ & $531,089,532$ & $646,754,162$ & 1,207 & $11,391,726,048$ \\
\hline VOLTA & $1,195,868,564$ & $207,847,507$ & $2,541,533,146$ & $779,173,586$ & $179,432,521$ & $462,735,738$ & & $6,113,762,137$ \\
\hline ASHANTI & $5,819,346,277$ & $5,576,137,641$ & $6,191,364,333$ & $2,464,051,544$ & $996,945,350$ & 188 & 20 & $22,763,216,633$ \\
\hline BRONGAHAFO & $1,815,349,522$ & $2,184,598,550$ & $4,010,776,673$ & $1,039,072,609$ & $180,653,218$ & 266, & & $10,375,344,273$ \\
\hline NORTHERN & $2,353,865,631$ & $66,575,895$ & $1,126,419,218$ & $2,307,344,595$ & $249,945,700$ & 1,049 & 1,18 & $8,336,007,437$ \\
\hline & & & & & & & & \\
\hline UPPER EAST & $893,064,725$ & $58,027,000$ & $\begin{array}{r}1,605,546,454 \\
\end{array}$ & $202,406,037$ & $\begin{array}{l}14,038,400 \\
145,714,077\end{array}$ & $\begin{array}{l}129,433,991 \\
129\end{array}$ & , 371,190 & $5,792,563,474$ \\
\hline \begin{tabular}{|l} 
TOTAL \\
\end{tabular} & $34,182,017,298$ & $17,687,981,298$ & $41,084,206,036$ & $23,005,721,180$ & $5,168,638,783$ & $4,416,406,472$ & $17,352,549,478$ & $142,897,520,545$ \\
\hline \multicolumn{9}{|c|}{ DISTRICT ASSEMBLIES IGF ITEM OUTTURN FOR 2003} \\
\hline \begin{tabular}{|l|l|l} 
REGION \\
\end{tabular} & RATES & LANDS & FEES \& FINES & LICENCES & RENT & INVESTMENT & MISCELLANEOUS & TOTAL \\
\hline WESTERN & $5,219,548,910$ & $10,650,075,101$ & $2,338,461,211$ & $4,053,447,511$ & $1,030,821,500$ & $167,385,102$ & $531,912,275$ & $23,991,651,610$ \\
\hline CENTRAL & $1,115,820,046$ & $1,095,746,215$ & $2,418,896,523$ & $1,399,362,173$ & $265,555,097$ & $570,843,050$ & $787,834,938$ & $7,654,058,042$ \\
\hline GREATER ACCRA & $20,601,698,811$ & $581,611,665$ & $25,146,835,043$ & $12,194,341,542$ & $4,421,413,206$ & $454,201,239$ & $6,175,211,560$ & $69,575,313,066$ \\
\hline EASTERN & $2,745,135,925$ & $1,483,223,108$ & $4,234,844,598$ & $1,567,445,277$ & $729,347,870$ & $293,214,473$ & 2,13 & $13,188,66$ \\
\hline VOLTA & $1,406,409,569$ & $272,118,663$ & $2,621,808,751$ & 4,583 & 226,291 & 535,454 & 06 & $6,750,28$ \\
\hline ASHANTI & $8,298,496,441$ & $5,977,599,520$ & $9,432,463,453$ & 3,575 & $1,316,2$ & 31 & 1,36 & $30,848,2$ \\
\hline BRONG AHAFO & $1,677,954,033$ & $13,614,380,046$ & $4,481,690,325$ & 1,24 & 00 & $32 s$ & 1,1 & $22,663,4$ \\
\hline NORTHERN & $1,434,269,278$ & $99,144,690$ & $1,592,022,795$ & 653 & 91 & 64 & & 767 \\
\hline UPPER WEST & $541,244,930$ & $12,808,000$ & $976,928,347$ & & $1,640,651,077$ & $788,948,389$ & & \\
\hline UPPER EAST & $\begin{array}{l}392,910,009 \\
392,01009\end{array}$ & $90,312,500$ & $2,418,426,035$ & $308,177,500$ & $\begin{array}{r}188,832,324 \\
\end{array}$ & $\begin{array}{l}395,461,047 \\
395,46\end{array}$ & $\begin{array}{l}317,857,979 \\
31\end{array}$ & $4,111,977,394$ \\
\hline TOTAL & $43,433,487,952$ & $33,877,019,508$ & $55,662,377,081$ & $25,835,861,898$ & $10,439,295,216$ & $4,985,941,814$ & $14,541,349,046$ & $188,775,332,515$ \\
\hline \multicolumn{9}{|c|}{ SIGF ITEM OUTTURNFOR 2004} \\
\hline REGION & RATES & LANDS & FEES \& FINES & LICENCES & RENT & INVESTMENT & MISCELLANEOUS & TOTAL \\
\hline WESTERN & $5,777,162,375$ & $18,667,764,600$ & $2,743,406,080$ & $3,738,712,491$ & $1,133,903,522$ & $373,048,245$ & $1,905,660,471$ & $34,339,657,784$ \\
\hline CENTRAL & $2,526,977,582$ & $974,588,042$ & $2,690,901,902$ & $1,687,230,790$ & $479,620,330$ & $512,533,394$ & $950,816,191$ & $9,822,668,231$ \\
\hline GREATER ACCRA & $25,100,784,493$ & $396,497,400$ & $30,454,241,698$ & $15,381,097,837$ & $5,302,254,521$ & $557,525,487$ & $8,534,347,188$ & $85,726,748,624$ \\
\hline EASTERN & $3,614,759,100$ & $1,913,969,973$ & $5,328,302,759$ & $2,255,311,086$ & $1,102,611,480$ & $367,921,192$ & $1,497,326,211$ & $16,080,201,801$ \\
\hline VOLTA & $2,492,171,460$ & $234,310,800$ & $3,976,683,890$ & $1,150,262,140$ & $642,444,290$ & $430,677,802$ & $756,500,640$ & $9,683,051,022$ \\
\hline ASHANTI & $10,007,944,760$ & $8,789,838,809$ & $11,061,939,682$ & $5,179,632,647$ & $1,601,892,092$ & $1,545,949,176$ & $2,025,395,698$ & $40,212,592,864$ \\
\hline BRONG AHAFO & $2,465,472,377$ & $2,652,009,858$ & $5,589,248,336$ & $1,431,239,383$ & $295,934,918$ & $371,767,406$ & $1,299,390,845$ & $14,105,063,123$ \\
\hline NORTHERN & $1,045,215,642$ & $147,020,443$ & $1,804,174,329$ & $503,348,250$ & $382,063,800$ & $315,623,883$ & $581,664,298$ & $4,779,110,645$ \\
\hline UPPER WEST & $492,902,232$ & $22,999,600$ & $1,053,392,815$ & $134,359,897$ & $59,232,846$ & $1,955,415,907$ & $990,274,522$ & $4,708,577,819$ \\
\hline UPPER EAST & $787,974,411$ & $131,080,430$ & $2,892,760,299$ & $293,644,323$ & $262,375,220$ & $827,717,747$ & $1,165,890,858$ & $6,361,443,288$ \\
\hline TOTAL & $54,311,364,432$ & $33,930,079,955$ & $67,595,051,790$ & $31,754,838,844$ & $11,262,333,019$ & $7,258,180,239$ & $19,707,266,922$ & $225,819,115,2$ d1 18 \\
\hline
\end{tabular}

